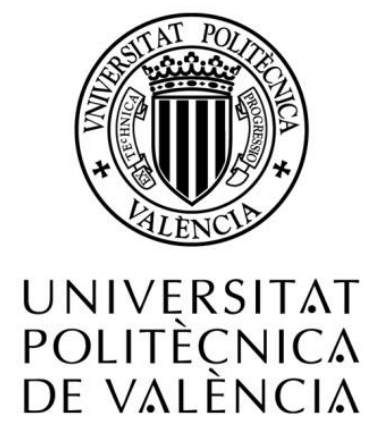

Programa de doctorado en Biotecnología

\title{
Estrategias de defensa a estrés químico en Saccharomyces cerevisiae: regulación genética del transporte multidroga y mecanismos de detoxificación.
}

Mạ Elena Vanacloig Pedrós

TESIS DOCTORAL

Directores

Dr. Markus Proft

Dra. Amparo Pascual-Ahuir Giner

Valencia, junio 2018 

La Dra. Amparo Pascual-Ahuir Giner, Doctora en Biología y, Profesora titular y Directora del Departamento de Biotecnología de la Escuela Técnica Superior de Ingeniería Agronómica y del Medio Natural de la Universidad Politécnica de Valencia, y el Dr. Markus Proft, Doctor en Biología y Científico Titular del Consejo Superior de Investigaciones Científicas en el Instituto de Biomedicina de Valencia,

\section{CERTIFICAN:}

Que la licenciada en Biotecnología por la Universidad Politécnica de Valencia, Mạ Elena Vanacloig Pedrós, ha realizado bajo su dirección el trabajo de investigación titulado "Estrategias de defensa a estrés químico en Saccharomyces cerevisiae: regulación genética del transporte multidroga y mecanismos de detoxificación" y autorizan su presentación para optar al grado de Doctora en Biotecnología.

Para que así conste, firman el presente documento en Valencia, a X de julio de 2018.

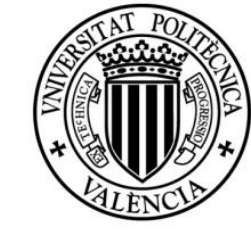

UNIVERSITAT POLITĖCNICA DE VALÈNCIA 



\section{RESUMEN}

En la presente tesis se han estudiado los distintos mecanismos de toxicidad de las micotoxinas citrinina y ocratoxina A y la respuesta adaptativa a xenobióticos en el modelo de levadura Saccharomyces cerevisiae, concretamente la regulación de los transportadores multidrogas del sistema PDR y sus factores de transcripción.

La respuesta a xenobióticos permite a las células eucariotas adaptarse y sobrevivir a la exposición de gran variedad de compuestos exógenos, como toxinas o fármacos. En esta respuesta participan distintos tipos de proteínas, principalmente transportadores de membrana y factores de transcripción. Para estudiar esta respuesta adaptativa sometimos las células de levadura a distintos tratamientos con las micotoxinas citrinina (CIT) y ocratoxina A (OTA), y los oxidantes menadiona (MEN), y peróxido de hidrógeno $\left(\mathrm{H}_{2} \mathrm{O}_{2}\right)$.

Las micotoxinas citrinina y ocratoxina A son metabolitos secundarios producidos por varios hongos filamentosos, principalmente de las familias Aspergillus y Penicillium, que contaminan alimentos básicos como maíz, trigo y arroz, y que son tóxicas para el ser humano. Aquí, estudiamos los mecanismos de toxicidad de ambas toxinas a través de experimentos de expresión génica con reporteros luciferasa, ensayos transcriptómicos, y ensayos fenotípicos con mutantes de pérdida de función para determinadas proteínas involucradas en la defensa antioxidante y de transporte multidroga. Los resultados muestran diferencia de los mecanismos de toxicidad entre ambas micotoxinas. CIT induce la expresión de numerosos genes involucrados en el transporte de drogas y la respuesta a estrés oxidativo, mientras que OTA activa, principalmente, la expresión de genes implicados en el desarrollo, como meiosis o esporulación, y en menor medida, genes relacionados con la respuesta a estrés oxidativo y al transporte multidroga.

En levadura, los transportadores multidroga de la membrana plasmática que eliminan compuestos tóxicos de la célula forman parte del denominado sistema PDR (pleiotropic drug resistance). Este sistema está compuesto por proteínas conservadas de bacterias a humanos, entre ellos, transportadores multidroga, pero también otro tipo de proteínas como factores de transcripción que se encargan de regular su expresión. En ocasiones, estos transportadores se encuentran sobreexpresados, lo que da lugar a un fenómeno conocido como resistencia pleiotrópica a drogas (PDR) o resistencia a múltiples drogas (MDR). Este proceso de resistencia es de gran importancia en diversos tratamientos médicos, como quimioterapia en cáncer, o antifúngicos, ya que disminuyen su eficiencia. Aquí, hemos estudiado el funcionamiento del sistema PDR en levadura de varios transportadores multidroga (Pdr5, Pdr15, Snq2, y Yor1) y factores de transcripción (Pdr1, Pdr3, Pdr8, Yrm1, Yrr1, y Stb5) mediante cuantificación de expresión luciferasa en promotores o sitios de reconocimiento concretos. Además, desarrollamos un sistema binario de plásmidos que nos permitiera estudiar las distintas sensibilidades de estos factores de transcripción a los xenobióticos de forma individualizada. 
Los resultados muestran que, de entre los transportadores multidroga estudiados, Pdr5 y Snq2 son los principales en la respuesta de adaptación frente a CIT, OTA y MEN, mientras que Pdr15 parece actuar como un transportador secundario. Además, la regulación de estos tres transportadores ante la exposición de citrinina está dirigida por el factor de transcripción Pdr1, porque el mutante de deleción $\Delta p d r 1$ no muestra actividad ante esta toxina. $S N Q 2$ es el único de los cuatro transportadores que se induce al tratar las células con $\mathrm{H}_{2} \mathrm{O}_{2}$. Pdr1 no sólo aparece como el principal factor de transcripción con CIT, sino que participa en la respuesta de todas las moléculas estudiadas, en mayor o menor medida. Este regulador activa la transcripción de genes en respuesta a CIT y OTA a través de los sitios específicos PDRE, al contrario que Pdr8 e Yrm1, que parecen actuar como reguladores negativos en respuesta a CIT a través de estos mismos elementos. Por último, empleamos un sistema binario de plásmidos que nos permite definir las distintas sensibilidades y especificidad a drogas por parte de los factores de transcripción de forma individual. Pdr1 es capaz de reconocer e inducir la activación de la expresión génica en todos los tratamientos, aunque muy levemente con $\mathrm{H}_{2} \mathrm{O}_{2}$. Yrr1 presenta inducción de la expresión génica ante CIT y, especialmente, OTA, indicando su capacidad de discriminación entre estas moléculas. Además, la activación se produce a través de elementos distintos a PDRE. Por último, Stb5 reconoce e induce la expresión génica en el tratamiento con $\mathrm{H}_{2} \mathrm{O}_{2}$ en mayor nivel que Pdr1. Los resultados muestran un importante nivel de regulación del sistema PDR, con Pdr1 como factor de transcripción principal, pero con la cooperación de otros reguladores más específicos. 


\section{SUMMARY}

In the present thesis, we have studied the different toxicity mechanisms of the mycotoxins citrinin and ochratoxin A and the adaptive response to xenobiotics in the yeast model of Saccharomyces cerevisiae, specifically the regulation of the multidrug transporters of the PDR network and its transcription factors.

The response to xenobiotics allows eukaryotic cells to adapt and survive the exposure to a wide variety of exogenous compounds, such as toxins or drugs. Different types of proteins participate in this response, mainly membrane transporters and transcription factors. To study this adaptive response we subjected the yeast cells to different treatments with the mycotoxins citrinin (CIT) and ochratoxin A (OTA), and oxidants menadione (MEN), and hydrogen peroxide $\left(\mathrm{H}_{2} \mathrm{O}_{2}\right)$.

The mycotoxins citrinin and ochratoxin A are secondary metabolites produced by several filamentous fungi, mainly from the families Aspergillus and Penicillium, which contaminate staple foods such as corn, wheat and rice, and which are toxic to humans. Here, we studied the toxicity mechanisms of both toxins through gene expression experiments with luciferase reporters, transcriptomic assays, and phenotypic assays with loss-of-function mutants for certain proteins involved in antioxidant defense and multidrug transport. The results show differences in the mechanisms of toxicity between both mycotoxins. CIT induces the expression of numerous genes involved in drug transport and the response to oxidative stress, whereas OTA activates, mainly, the expression of genes involved in development, such as meiosis or sporulation, and to a lesser extent, genes related to response to oxidative stress and multidrug transport.

In yeast, multidrug transporters of the plasma membrane that remove toxic compounds from the cell are part of the so-called PDR (pleiotropic drug resistance) network.This system is composed of proteins conserved from bacteria to humans, including multidrug transporters, but also other proteins such as transcription factors that regulate their expression. Occasionally, these transporters are overexpressed, which leads to a phenomenon known as pleiotropic drug resistance (PDR) or multidrug resistance (MDR). This resistance process is very important in various medical treatments, such as chemotherapy in cancer, or antifungals, since they reduce their efficiency. Here, we have studied the function of the PDR multidrug transporters (Pdr5, Pdr15, Snq2, and Yor1) and transcription factors (Pdr1, Pdr3, Pdr8, Yrm1, Yrr1, and Stb5) by quantifying luciferase expression in promoters or specific recognition sites. In addition, we developed a binary plasmid system that allowed us to study the different sensitivities to xenobiotics of these transcription factors individually.

The results show that, among the studied multidrug transporters, Pdr5 and Snq2 have major roles in the adaptation response to CIT, OTA and MEN, while Pdr15 seems to act as a secondary transporter. Moreover, the regulation of these three transporters upon exposure to citrinin is directed by the transcription factor Pdr1, because the deletion mutant $\triangle p d r l$ shows no activity upon CIT exposure. $S N Q 2$ is the only one of the four 
transporters that is induced by treating cells with $\mathrm{H}_{2} \mathrm{O}_{2}$. Pdr1 not only appears as the main transcription factor upon CIT treatment, but also participates, to a greater or lesser extent, in the response to all studied molecules. This regulator activates the transcription of genes in response to CIT and OTA through specific PDRE sites, in contrast to Pdr8 and Yrm1, which appear to act as negative regulators in response to CIT through these same elements. Finally, we use a binary plasmid system that allows us to define the different sensitivities and specificity to drugs by the transcription factors individually. Pdr1 is able to recognize and induce the activation of gene expression in all treatments, albeit very slightly with $\mathrm{H}_{2} \mathrm{O}_{2}$. Yrr1 shows induction of gene expression with CIT and, especially, OTA, indicating its ability to discriminate between these molecules. Furthermore, activation occurs through elements other than PDRE. Finally, Stb5 recognizes and induces gene expression in $\mathrm{H}_{2} \mathrm{O}_{2}$ treatment at a higher level than Pdr1. These results show an important level of regulation of the PDR network, with Pdr1 as the main transcription factor, but with the cooperation of more specific regulators. 


\section{RESUM}

En la present tesi s'han estudiat els diferents mecanismes de toxicitat de les micotoxines citrinina i ocratoxina A i la resposta adaptativa a xenobiòtics en el model de llevat Saccharomyces cerevisiae, concretament la regulació dels transportadors multidroga del sistema PDR i els seus factors de transcripció.

La resposta a xenobiòtics permet a les cèl-lules eucariotes adaptar-se i sobreviure a l'exposició de gran varietat de compostos exògens, com toxines o fàrmacs. En aquesta resposta participen diferents tipus de proteïnes, principalment transportadors de membrana $\mathrm{i}$ factors de transcripció. Per estudiar aquesta resposta adaptativa vam sotmetre les cèl-lules de llevat a diferents tractaments amb les micotoxines citrinina (CIT) i ocratoxina A (OTA), i els oxidants menadiona (MEN), i peròxid d'hidrogen $\left(\mathrm{H}_{2} \mathrm{O}_{2}\right)$.

Les micotoxines citrinina i ocratoxina A són metabòlits secundaris produïts per diversos fongs filamentosos, principalment de les famílies Aspergillus i Penicillium, que contaminen aliments bàsics com dacsa, blat i arròs, i que són tòxiques per a l'ésser humà. Ací, estudiem els mecanismes de toxicitat de les dues toxines a través d'experiments d'expressió gènica amb reporters luciferasa, assaigs transcriptòmics, i assajos fenotípics amb mutants de pèrdua de funció per a determinades proteïnes involucrades en la defensa antioxidant i de transport multidroga. Els resultats mostren diferència dels mecanismes de toxicitat entre les dues micotoxines. CIT indueix l'expressió de nombrosos gens involucrats en el transport de drogues i la resposta a estrès oxidatiu, mentre que OTA activa, principalment, l'expressió de gens implicats en el desenvolupament, com meiosi o esporulació, i en menor mesura, gens relacionats amb la resposta a estrès oxidatiu $i$ al transport multidroga.

En llevat, els transportadors multidroga de la membrana plasmàtica que eliminen compostos tòxics de la cèl-lula formen part de l'anomenat sistema PDR (pleiotropic drug resistance). Aquest sistema està compost per proteïnes conservades de bacteria a humans, entre ells, transportadors multidroga, però també per un altre tipus de proteïnes com factors de transcripció que s'encarreguen de regular la seua expressió. De vegades, aquests transportadors es troben sobreexpressats, el que dóna lloc a un fenomen conegut com a resistència pleiotrópica a drogues (PDR) o resistència a múltiples drogues (MDR). Aquest procés de resistència és de gran importància en diversos tractaments mèdics, com quimioteràpia en càncer, o antifúngics, ja que disminueixen la seua eficiència. Ací hem estudiat el funcionament del sistema PDR en llevat de diversos transportadors multidroga (Pdr5, Pdr15, Snq2, i Yor1) i factors de transcripció (Pdr1, Pdr3, Pdr8, Yrm1, Yrr1, i Stb5) mitjançant quantificació d'expressió luciferasa en promotors o llocs de reconeixement concrets. A més d'això, vam desenvolupar un sistema binari de plasmidis que ens permetera estudiar les diferents sensibilitats d'aquests factors de transcripció als xenobiòtics de forma individualitzada. 
Els resultats mostren que, d'entre els transportadors multidroga estudiats, Pdr5 i Snq2 són els principals en la resposta d'adaptació davant de CIT, OTA i MEN, mentre que Pdr15 sembla actuar com un transportador secundari. A més d'això, la regulació d'aquests tres transportadors davant l'exposició de citrinina està dirigida pel factor de transcripció Pdr1, perquè el mutant de deleció $\Delta p d r 1$ no mostra activitat davant d'aquesta toxina. $S N Q 2$ és l'únic dels quatre transportadors que s'indueix en tractar les cèl-lules amb $\mathrm{H}_{2} \mathrm{O}_{2}$. Pdr1 no només apareix com el principal factor de transcripció amb CIT, sinó que participa en la resposta de totes les molècules estudiades, en major o menor mesura. Aquest regulador activa la transcripció de gens en resposta a CIT i OTA a través dels llocs específics PDRE, al contrari que Pdr8 i Yrm1, que semblen actuar com a reguladors negatius en resposta a CIT a través d'aquests mateixos elements. Finalment, fem servir un sistema binari de plasmidis que enspermet definir les diferents sensibilitats i especificitat a drogues per part dels factors de transcripció de forma individual. Pdr1 és capaç de reconèixer i induir l'activació de l'expressió gènica en tots els tractaments, encara que molt lleument amb $\mathrm{H}_{2} \mathrm{O}_{2}$. Yrr1 presenta inducció de l'expressió gènica davant CIT i, especialment, OTA, indicant la seua capacitat de discriminació entre aquestes molècules. A més d'això, l'activació es produeix a través d'elements diferents a PDRE. Finalment, Stb5 reconeix i indueix l'expressió gènica en el tractament amb $\mathrm{H}_{2} \mathrm{O}_{2}$ en major nivell que Pdr1. Els resultats mostren un important nivell de regulació del sistema PDR, amb Pdr1 com a factor de transcripció principal, però amb la cooperació d'altres reguladors més específics. 


\section{$\underline{\text { ÍNDICE }}$}

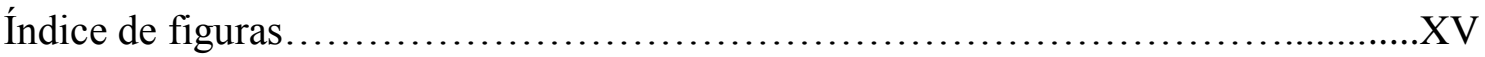

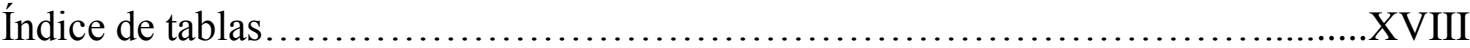

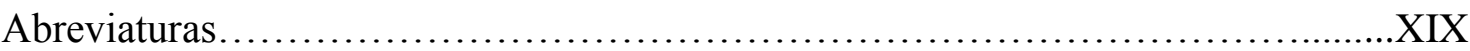

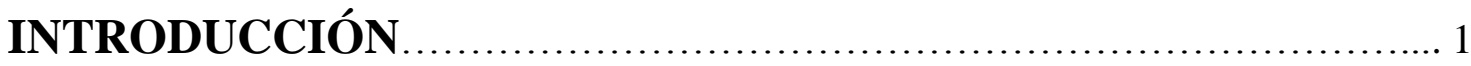

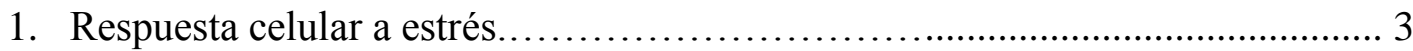

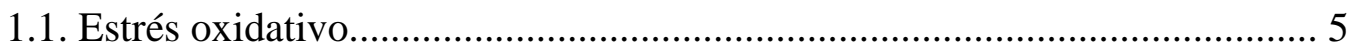

2. Resistencia pleiotrópica a drogas (PDR) ........................................

2.1.Resistencia a múltiples drogas: Definición y consecuencias

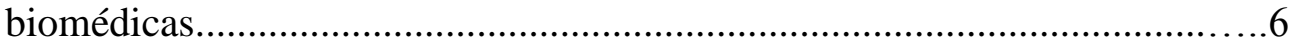

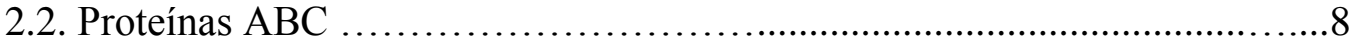

2.3. Sistema PDR en Saccharomyces cerevisiae ................................................10

2.3.1. Transportadores $\mathrm{ABC}$ del sistema de resistencia pleiotrópica a drogas (PDR) .................................................................................

2.3.2. Regulación genética del sistema PDR de levadura...........................13

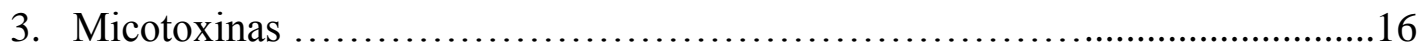

4. Antecedentes............................................................................. 17

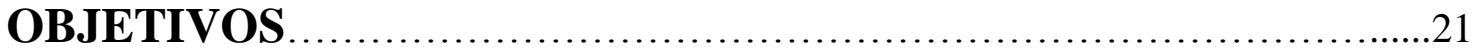

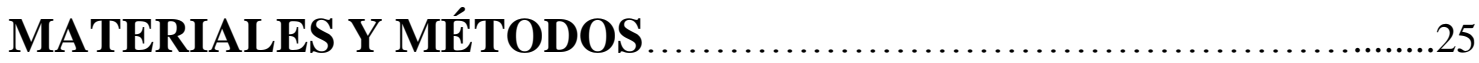

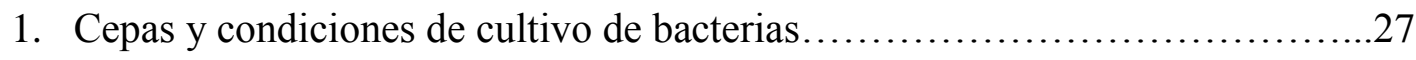

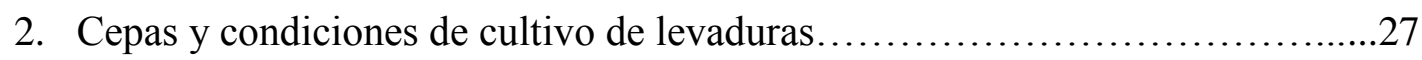

2.1.Disrupción génica …………………………………………………….... 28

2.1.1. Construcción del cassette de disrupción génica...................................28

2.1.2. Transformación de levadura con construcción de disrupción............29

2.1.3. Verificación de la deleción.............................................................29

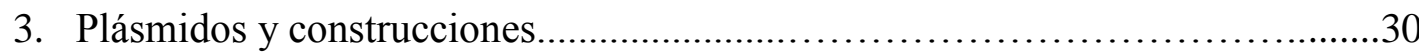

3.1.Construcción 1: Fusión de los promotores PDR5, PDR15, SNQ2, y YOR1

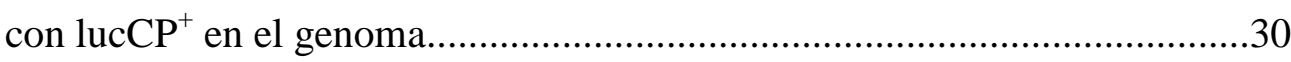

3.2.Construcción 2: pAG413-3xPDRE-lucCP ${ }^{+}$..................................................31

3.3.Construcción 3: Sistema binario GAL1 $1_{\mathrm{UAS}}-\mathrm{lucCP}^{+}$y Gal4 DBD $-\mathrm{Pdr} . . . . . . . . . . . . .32$

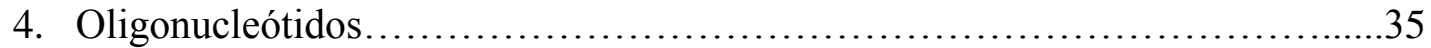

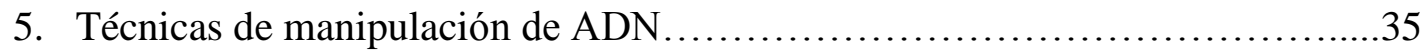

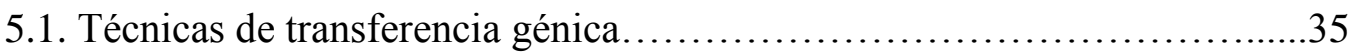


5.1.1. Transformación de bacterias....................................35

5.1.2. Transformación de levaduras......................................36

5.2. Técnicas de extracción de ADN...........................................

5.3.Amplificación y purificación de fragmentos de ADN................................ 37

5.4. Digestión con enzimas de restricción y electroforesis en gel de

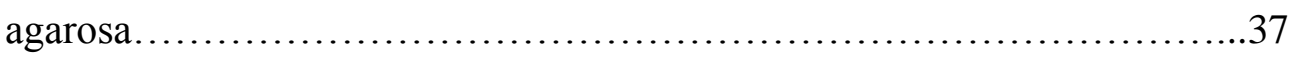

6. Análisis de expresión de levadura: RT-PCR y microarray .......................38

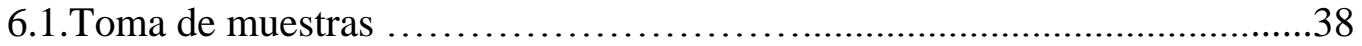

6.2. Extracción de ARN con el método del "fenol ácido" $(\mathrm{pH}=4.3) \ldots \ldots \ldots . . .38$

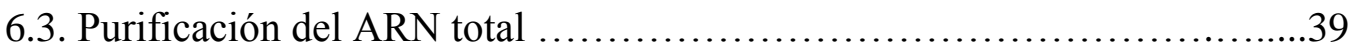

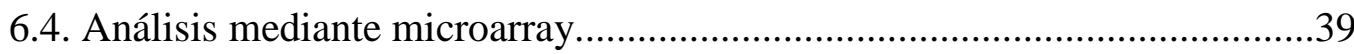

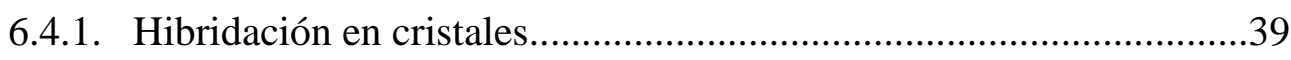

6.4.2. Análisis bioinformático y estadístico.................................................40

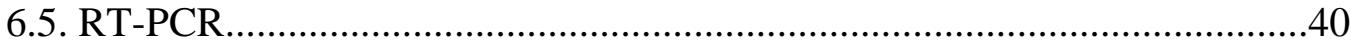

6.5.1. Síntesis de ADNc por transcripción reversa.......................................40

6.5.2. Análisis mediante PCR cuantitativa a tiempo real (RT-qPCR).........41

7. Técnicas de manipulación de proteínas ......................................41

7.1.Obtención de extractos proteicos totales .......................................41

7.1.1. Obtención de extractos proteicos totales por hervido en tampón

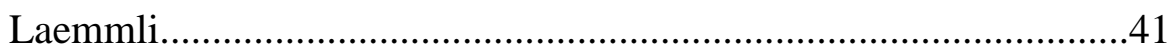

7.1.2. Obtención de extractos proteicos totales por agitación con

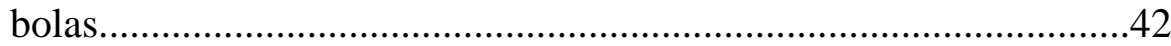

7.2.Electroforesis de proteínas ...........................................42

7.3.Transferencia a membrana de proteínas (Western Blot)..................43

7.4.Detección inmunológica de proteínas .................................................43

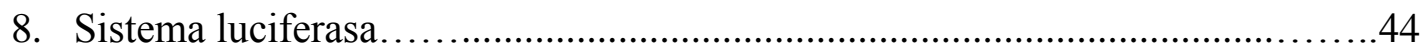

9. Ensayos de sensibilidad: crecimiento en medio sólido (Goteo)..................44

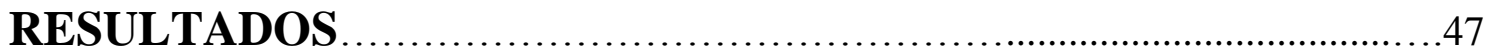

CAPÍtULO 1: MECANISMOS DE TOXICIDAD DE CITRININA (CIT) Y

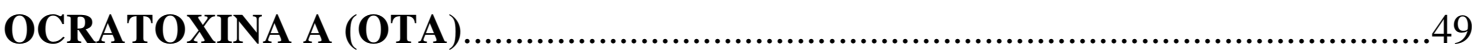

1. Perfiles de expresión génica de los promotores GRE2 y SOD2 ante CIT y

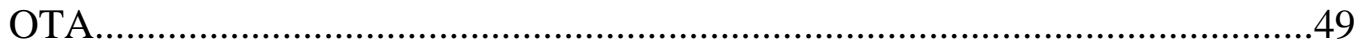

1.1. Respuesta dosis-dependiente de la cepa wild type .........................49 
1.2. Comparación de wild type y mutante $\Delta p d r 5$

.50

1.3. Respuesta de reporteros luciferasa GRE2-lucCP ${ }^{+}$y SOD2-lucCP ${ }^{+}$frente a la combinación de citrinina y ocratoxina A

2. Estudio transcriptómico del mutante $\Delta p d r 5$ sometido a distintas condiciones de citrinina y ocratoxina A .52

2.1. Análisis de expresión genómica mediante microarray. .52

3. Estudio de la posible relación del estrés oxidativo con los efectos causados por citrinina y ocratoxina A

3.1.Estudio de reporteros luciferasa GRE2-lucCP ${ }^{+}$, 3xAP1-lucCP ${ }^{+}$, y PDR5lucCP ${ }^{+}$sometidos a CIT y OTA

3.2.CIT causa estrés oxidativo que se agrava en mutantes con defectos en la respuesta antioxidante

CAPÍtULO 2: ANÁLISIS EN TIEMPO REAL DE LA RESPUESTA MULTIDROGA EN LEVADURA: REGULACIÓN DIFERENCIAL DE LOS TRANSPORTADORES PDR Y SELECTIVIDAD DE LOS ACTIVADORES TRANSCRIPCIONALES INVOLUCRADOS. .67

1. Estudio transcripcional de los transportadores Pdr5, Pdr15, Snq2 y Yor1 tratados con varios xenobióticos .67

1.1. Respuesta diferencial de transportadores multidroga a las micotoxinas CIT y OTA.

1.2. Respuesta diferencial de transportadores multidroga a menadiona $y$ $\mathrm{H}_{2} \mathrm{O}_{2}$

2. Función de los activadores Pdr1 y Pdr3 en la regulación transcripcional de transportadores multidroga por CIT. .71

3. Estudio de los factores de transcripción Pdr en la respuesta adaptativa celular a micotoxinas y otros compuestos

3.1.Respuesta adaptativa a citrinina y ocratoxina A a través de los elementos PDRE. .74

4. Reconocimiento de xenobióticos por parte de los factores de transcripción Pdr.

4.1. Análisis bioinformático. .79

4.2. Estudio del reconocimiento y activación por compuestos químicos de los factores Pdr. .82 


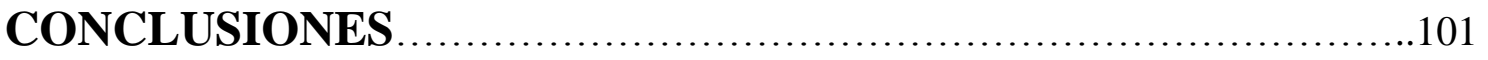

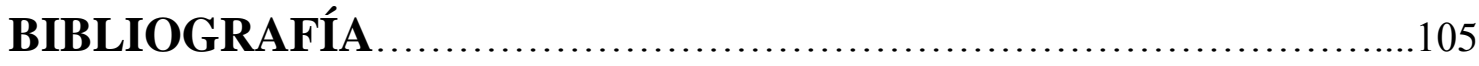

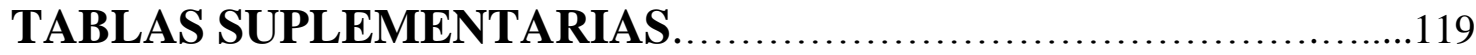

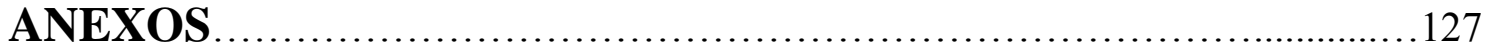

Anexo 1. Pascual-Ahuir, A.; Vanacloig-Pedros, E.; Proft, M. Toxicity Mechanisms of the Food Contaminant Citrinin: Application of a Quantitative Yeast Model. Nutrients 2014, 6, 2077-2087

Anexo 2. Vanacloig-Pedros, E.; Proft, M.; Pascual-Ahuir, A. Different Toxicity Mechanisms for Citrinin and Ochratoxin A Revealed by Transcriptomic Analysis in Yeast. Toxins 2016, 8, 273. 140 


\section{ÍNDICE DE FIGURAS}

\section{INTRODUCCIÓN}

Figura 1. Localización celular de los transportadres de membrana ABC de $S$.

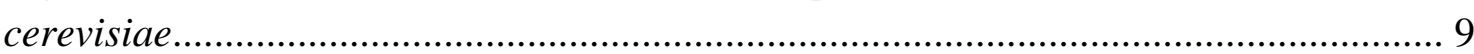

Figura 2. Topología y organización de dominios de las subfamilias de proteínas ABC de

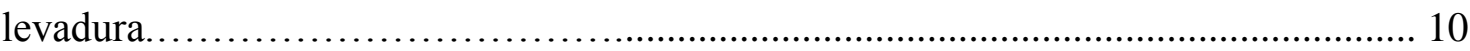

Figura 3. Esquema del sistema PDR (Pleiotropic Drug Resistance) ......................11

Figura 4. Esquema de la regulación del sistema PDR de levadura............................. 15

\section{MATERIALES Y MÉTODOS}

Figura 5. Deleción de genes de levadura con el marcador $\operatorname{kan}^{\mathrm{r}}$.............................28

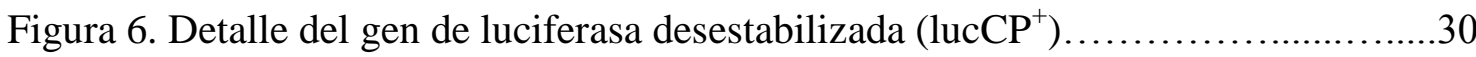

Figura 7. Esquema de la construcción1 ............................................... 31

Figura 8. Cassette de integración................................................... 31

Figura 9. Esquema construcción 2 (pAG413-3xPDRE-lucCP $\left.{ }^{+}\right) \ldots \ldots \ldots \ldots \ldots \ldots \ldots . \ldots . \ldots . \ldots . \ldots . \ldots 2$

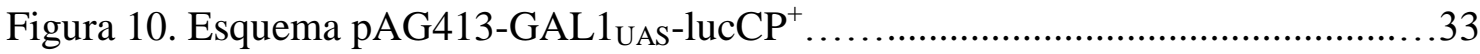

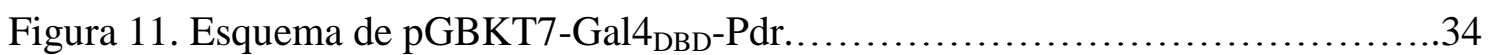

Figura 12. Esquema del sistema luciferasa .................................................44

\section{RESULTADOS}

Figura 13. Perfiles dosis-respuesta de la expresión luciferasa de los promotores GRE2 y

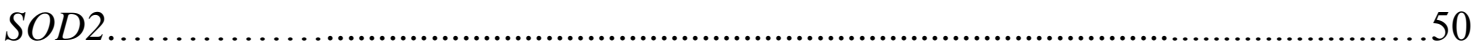

Figura 14. Comparación de perfiles dosis-respuesta de la expresión luciferasa de los

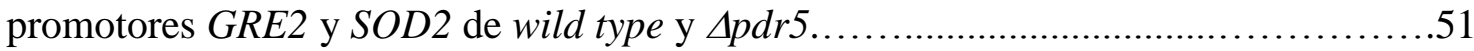

Figura 15. Efecto sinérgico de citrinina y ocratoxina A...................................52

Figura 16. Comparación de genes inducidos en tratamientos con CIT y OTA con un

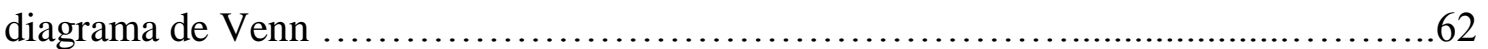

Figura 17. OTA y CIT inducen reporteros de estrés de forma diferencial................63

Figura 18. Actividad máxima (Amax) de los reporteros GRE2, 3xAP1, y PDR5-

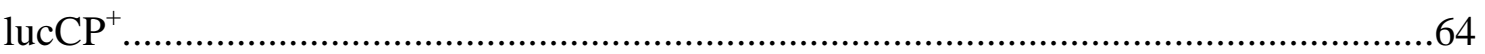

Figura 19. La toxicidad de CIT, pero no de OTA, aumenta en mutantes con defectos en la respuesta adaptativa a estrés oxidativo o el transporte multidroga..........................65 
Figura 20. Pdr5, Pdr15, Snq2 y Yor1 responden de forma diferencial a las micotoxinas CIT y OTA

Figura 21. Comparación de la activación de PDR5, PDR15, SNQ2 y YOR1 por CIT y OTA

Figura 22. Pdr5, Pdr15, Snq2 y Yor1 responden de forma diferencial a menadiona y

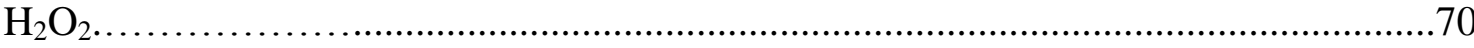

Figura 23. Actividad máxima (Amax) de los reporteros PDR5-, PDR15-, SNQ2- y

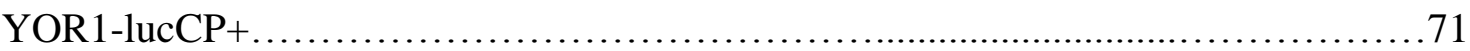

Figura 24. Función de Pdr1 y Pdr3 en la activación de Pdr5, Pdr15 y Snq2 por CIT ........................................................................... 72

Figura 25. Comparación de las funciones de Pdr1 y Pdr3 en la activación de

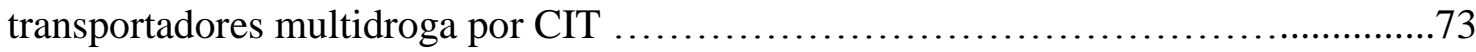

Figura 26. Función de los activadores transcripcionales Pdr en la regulación génica a través de elementos PDRE por CIT ................................................................ 75

Figura 27. Función de los activadores transcripcionales Pdr en la regulación génica a través de elementos PDRE por OTA......................................................76

Figura 28. Comparación de las funciones de Pdr1, Pdr3, Pdr8, Yrm1, e Yrr1 en la activación génica a través de PDRE por CIT y OTA.................................77

Figura 29. Representación del sistema de doble plásmido UAS-Pdr........................78

Figura 30. Comprobación de la expresión constitutiva de proteínas de fusión Gal4 ${ }_{\mathrm{DBD}^{-}}$

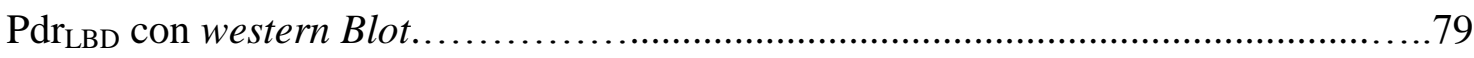

Figura 31. Comparación de la secuencia aminoacídica de la región XBD de Pdr1 y Pdr3. 80

Figura 32. Comparación de la secuencia aminoacídica de la región DBD de Pdr1 y

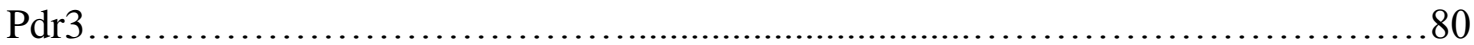

Figura 33. Comparación de las secuencias proteicas de factores de transcripción Pdr .81

Figura 34. Representación filogenética de factores de transcripción Pdr. .82

Figura 35. Comparación de perfiles de activación por citrinina de los factores de transcripción Pdr .83

Figura 36. Comparación de perfiles de activación por ocratoxina A de los factores de transcripción Pdr. .84 
Figura 37. Comparación de perfiles de activación por menadiona de los factores de transcripción Pdr .85

Figura 38. Comparación de perfiles de activación por $\mathrm{H}_{2} \mathrm{O}_{2}$ de los factores de transcripción Pdr.

Figura 39. Comparación de los perfiles dosis-respuesta entre los factores transcripcionales Pdr en respuesta a diferentes xenobióticos 87

Figura 40. Comparación de los valores de inducción máxima entre los factores transcripcionales Pdr en respuesta a diferentes xenobióticos. 88

\section{DISCUSIÓN}

Figura 41. Estructura molecular de peróxido de hidrógeno, menadiona, citrinina, y ocratoxina A. 


\section{ÍNDICE DE TABLAS}

Tabla 1. Genes sobreexpresados con FC>5 en tratamiento con 200ppm de CIT........53

Tabla 2. Genes sobreexpresados con FC>5 en tratamiento con 200ppm de OTA........55

Tabla 3. Genes sobreexpresados con FC >5 en tratamiento combinado de CIT/OTA....58

Tabla 4. Grupos funcionales de genes inducidos por tratamientos con CIT, OTA, y CIT/OTA ............................................................61 
ABREVIATURAS

aa: Aminoácido

ABC: dominio de unión a ATP (ATP-Binding Domain)

AD: Dominio de activación

ade: adenina

ADN: Ácido desoxirribonucleico.

ADNc: Ácido desoxirribonucleico complementario.

ADP: Adenosín difosfato

Amax: Actividad máxima

Amp: Ampicilina

ARN: Ácido ribonucleico

ARNm: ARN mensajero

ATP: Adenosín trifosfato

BSA: Albúmina de suero bovino

CIT: citrinina

Ct: (Threshold Cycle) número de ciclos necesarios para que se produzca un aumento de fluorescencia significativo con respecto a la señal base

DBD: Dominio de unión a ADN

DMSO: dimetilsulfóxido

DNA: deoxyribonucleic acid

dNTP: Deoxiribonucleótido

DTT: Ditiotritol

EDTA: Ácido Etilenodiaminotetracético

FC: Fold change (número de veces de cambio de un valor con respecto al control)

FI: Fold Induction (valores de inducción)

h: hora

his: histidina

IE: Eficiencia de la inmunoprecipitación

IP: muestras inmunoprecipitadas

kan: kanamicina

LB: Luria Bertani (medio)

LBD: dominio de unión a ligando (Ligand Binding Domain)

leu: leucina

lucCP ${ }^{+}$: gen reportero de la luciferasa desestabilizada

MDR: resistencia multidroga (Multidrug Resistance) 
MEN: menadiona

met: metionina

min: minuto

mRNA: RNA mensajero

OD: Densidad Óptica

OTA: ocratoxina A

pb: pares de bases

PCR: Reacción en Cadena de la Polimerasa

PDR: resistencia pleiotrópica a drogas (Pleiotropic Drug Resistance)

PDRE: elementos de resistencia pleiotrópica a drogas

PMSF: fenilmetilsulfonilo

ppm: partes por millón

PVDF: Polivinilideno de difluorido

qPCR: PCR cuantitativa

RNA: Ribonucleic acid (Ácido ribonucleico)

ROS: Especies Reactivas de Oxígeno (Reactive Oxygen Species).

rpm: revoluciones por minuto

rRNA: RNA ribosomal

RT: retrotranscripción

RT-PCR: PCR asociada a retrotranscripción

RT-qPCR: Reacción en cadena de la polimerasa cuantitativa a tiempo real

SD: Medio Sintético Definido (Synthetic Defined)

SDS: Dodecil Sulfato Sódico

trp: triptófano

UAS: secuencia de activación aguas arriba (Upstream Activation Sequence)

ura: uracilo

WT: wild type (cepa silvestre)

XBD: dominio de unión a xenobióticos (Xenobiotic Binding Domain)

YPD: Extracto de levadura-Peptona-Dextrosa (Yeast extract-Peptone-Dextrose) 
INTRODUCCIÓN 

Las células, para mantener su supervivencia y tener un buen funcionamiento necesitan encontrarse en un estado de equilibrio u homeostasis. Esta situación se ve afectada continuamente no sólo por cambios fisiológicos propios de las células, sino también por las diversas condiciones ambientales a las que son sometidas. Estas situaciones externas pueden ser variaciones en temperatura, $\mathrm{pH}$, concentración de iones, presencia de tóxicos, etc., y causan un estrés en la célula que produce una respuesta adaptativa inmediata y finamente regulada para recuperar de nuevo el estado de equilibrio.

A lo largo de su vida, todas las células se ven sometidas a distintos estreses químicos. En estas situaciones de estrés, la respuesta de adaptación celular se basa, mayormente, en el bombeo del compuesto tóxico fuera de la célula, o a determinados orgánulos, mediante diversos transportadores, así como la activación de enzimas detoxificadoras que permitan la degradación de dichas moléculas.

Los transportadores PDR (pleiotropic drug resistance), pertenecientes a la superfamilia ATP-binding cassette (ABC) son los responsables de la expulsión, o almacenamiento en orgánulos, de numerosas moléculas tóxicas para la célula, normalmente de origen exógeno, aunque algunas también generadas por la propia célula. Esta familia de proteínas se encuentra conservada en la mayoría de organismos por su importante labor.

Para estudiar este fenómeno de adaptación a estrés químico empleamos como sistema modelo la levadura Saccharomyces cerevisiae. Este organismo unicelular eucariota es empleado en el estudio de la respuesta adaptativa a estrés por su facilidad de utilización y manipulación genética, bajo coste y rapidez de crecimiento, y permite extrapolar, en gran medida, los resultados obtenidos al resto de células eucariotas, pudiendo servir como primera aproximación para el estudio de la resistencia multidroga en células eucariotas.

\section{Respuesta celular a estrés.}

Las células, a lo largo de su existencia, se encuentran con una amplia variedad de condiciones externas e internas que pueden llegar a inducir estrés en ellas. Este estrés se puede definir como una disrupción de la homeostasis o estado de equilibrio de la célula. Este desequilibrio puede llegar a amenazar su buen funcionamiento, e incluso, su supervivencia, ya que puede causar una acumulación de daños en el ADN, y otras moléculas, como proteínas y lípidos. De esta forma, podemos decir que la respuesta 
Introducción

celular a estrés es una reacción defensiva ante los cambios de las condiciones ambientales, como pH, temperatura, concentración de iones, o compuestos tóxicos, que causan un desequilibrio en las condiciones internas de la célula y un posible daño a su correcto funcionamiento y estructuras, y cuyo objetivo es permitir a la célula volver a un estado de equilibrio igual al anterior o distinto de adaptación al nuevo entorno.

Estos cambios suceden de forma continua y son sobrellevados por la célula habitualmente sin grandes problemas mediante mecanismos muy bien regulados, por ejemplo, a nivel génico. Los procesos implicados en las respuestas de adaptación dependen del tipo de estrés, y consisten tanto en acciones de protección y adaptación inmediata como de larga duración, pudiendo llevar a desarrollar nuevas variaciones fenotípicas en las células como adaptación evolutiva (López-Maury et al., 2008)

La respuesta celular ante un estrés consiste, en primer lugar, en el reconocimiento específico del estrés, para, a continuación, desencadenar una serie de acciones que permitan a la célula volver a un estado de equilibrio. Estas acciones se basan en la generación y transducción de señales que pueden iniciar una remodelación de cromatina y reprogramación génica que active mecanismos efectores de adaptación a dicho estrés (de Nadal et al., 2011; Taymaz-Nikerel et al., 2016; Vihervaara et al., 2018). Varios estudios mostraron que la reorganización a nivel genómico en levadura ante distintos estreses llega a implicar, aproximadamente, el 10\% de su genoma. Estos grupos de genes incluyen tanto los que son activados de forma específica a determinados estreses como los que lo hacen de forma inespecífica, e intervienen en distintos procesos celulares, como defensa a especies reactivas de oxígeno (ROS), síntesis de compuestos protectores, o reparación de ADN y proteínas (Gasch et al., 2000; Causton et al., 2001). Por otra parte, también se ha visto, que hay una coordinación entre la activación de genes de respuesta a estrés y la represión de genes constitutivos y de desarrollo de las células para permitir la supervivencia de la célula (Gasch et al., 2000; Causton et al., 2001; Vanacloig-Pedrós et al., 2015; López-Maury et al., 2008; Vihervaara et al., 2018).

Esta reprogramación transcripcional se encuentra muy altamente regulada para no producir daños mayores a la célula, ya que implica la activación y represión simultánea de múltiples genes y los procesos celulares que conllevan (Ni et al., 2009; Vihervaara et al., 2018). 


\subsection{Estrés oxidativo.}

El estrés oxidativo se ha descrito como un desequilibrio entre la producción de oxidantes (especies reactivas de oxígeno (ROS)) y los mecanismos antioxidantes de un organismo, en favor de los oxidantes (Sies, 1985). Al producirse una disrupción del equilibrio redox, ésto puede ocasionar daño a distintos componentes celulares y dar lugar a peroxidación lipídica, y oxidación proteica o del ADN, pudiendo producir roturas en las cadenas de ácidos nucleicos, bloqueo de la replicación, o mutagénesis. (Sies, 2015).

Las especies reactivas de oxígeno (ROS) se generan por la reducción parcial del $\mathrm{O}_{2}$, incluyendo el anión superóxido $\left(\mathrm{O}_{2}^{-}\right)$, el peróxido de hidrógeno $\left(\mathrm{H}_{2} \mathrm{O}_{2}\right)$, o el radical hidroxilo $\left(\mathrm{OH}^{-}\right)$, y son inestables y altamente reactivas. La aportación de ROS a la célula proviene tanto del entorno (radiación, luz, xenobióticos) como de procesos metabólicos internos (respiración mitocondrial, $\beta$-oxidación de ácidos grasos), pero de entre todos, se considera que la respiración mitocondrial es la principal fuente de ROS en células eucariotas a través del proceso de fosforilación oxidativa (Cadenas and Davies, 2000; Murphy, 2009).

El estrés oxidativo ocasionado por la acumulación de ROS ha sido ligado a múltiples patologías, entre ellas enfermedades neurodegenerativas, diabetes, cáncer y envejecimiento prematuro, donde el equilibrio redox se encuentra alterado (Halliwell, 2006; Ye et al., 2015). Pero, a pesar que ROS pueden ocasionar grandes daños e incluso llevar a la muerte celular, cada vez hay más estudios que indican que, en los niveles adecuados, son fundamentales como moléculas señalizadoras de distintos procesos fisiológicos (Schieber and Chandel, 2014; Vakifahmetoglu-Norberg et al., 2017; Sena and Chandel, 2012).

Todos los organismos con procesos metabólicos aeróbicos están expuestos a estrés oxidativo, por lo que han desarrollado mecanismos para proteger sus componentes celulares del posible daño producido por ROS y mantener su estado redox. Las células de la levadura Saccharomyces cerevisiae tienen diversos sistemas de defensa frente a estrés oxidativo, tanto a nivel enzimático como no enzimático. Los mecanismos no enzimáticos consisten en pequeñas moléculas que actúan como scavengers o secuestradores de radicales libres, y entre ellos encontramos los antioxidantes glutatión, poliaminas y ácido ascórbico o vitamina C. Entre las enzimas que catalizan reacciones 
Introducción

para la eliminación o reducción de ROS encontramos superóxido dismutasas (SOD), catalasas, peroxidasas y reductasas (Jamieson, 1998; Morano et al. 2012)

La respuesta a estrés oxidativo a nivel transcripcional sucede de forma específica de ROS pero también hay una activación de genes más inespecíficos, activos con distintos estreses, generalmente implicados en la detoxificación, reparación del daño y recuperación de la célula, y cuya regulación está mayormente controlada por los factores de transcripción a estrés general Msn2 y Msn4 (Gasch et al., 2000; Thorpe et al., 2004). La respuesta específica a estrés oxidativo se encuentra regulada principalmente a través de los factores de transcripción Yap1 y Skn7. A pesar de que la regulación transcripcional depende del tipo de oxidante, estos dos factores, especialmente Yap1, participan en la activación de un amplio número de genes implicados en los mecanismos de defensa antioxidante específico de ROS y bajo distintos oxidantes (Thorpe et al., 2004; Morano et al., 2012).

Anteriormente hemos indicado que la mitocondria, durante la respiración mitocondrial, es la principal fuente de ROS en la célula, pero no es la única. Entre las fuentes de estrés oxidativo se encuentran los xenobióticos. La exposición de las células a xenobióticos (compuestos externos al organismo procedentes del ambiente como toxinas o fármacos) produce la activación de la respuesta de adaptación a dichos compuestos. Parte de esta adaptación consiste en la metabolización y biotransformación de estos compuestos, pudiendo generarse especies reactivas de oxígeno (ROS) que pueden dar lugar a estrés oxidativo (Pagano et al., 2003; Klotz and Steinbrenner, 2017).

\section{Resistencia pleiotrópica a drogas (PDR):}

\subsection{Resistencia a múltiples drogas: Definición y consecuencias biomédicas.}

Las células eucariotas tienen mecanismos en respuesta a xenobióticos que las capacita para tolerar y resistir, simultáneamente, la toxicidad de gran variedad de compuestos no relacionados ni funcional ni estructuralmente, como toxinas o fármacos. Esta habilidad se conoce como resistencia pleiotrópica a drogas (pleiotropic drug resistance o PDR) $\mathrm{o}$, también, resistencia multidroga (multidrug resistance o MDR), y se encuentra en gran cantidad de organismos, desde bacterias a mamíferos. El principal mecanismo causante de esta resistencia multidroga es la sobreexpresión de transportadores de membrana. Hay dos tipos de familias de transportadores responsables de MDR que se 
encargan de eliminar los xenobióticos con distintas estrategias: ATP-binding cassette (ABC) y Major facilitator superfamily (MFS). Las proteínas ABC son transportadores activos primarios que emplean la energía de la hidrólisis del ATP para transportar los compuestos, mientras que las MFS son transportadores activos secundarios que utilizan el gradiente electroquímico de los protones y tienen un menor número de sustratos (SaCorreia et al., 2009; Cannon et al., 2009).

Estos transportadores se encargan de expulsar los compuestos dañinos (exógenos como drogas y toxinas, y otros generados durante algunos procesos celulares) o los acumulan en orgánulos como la vacuola (Jungwirth and Kuchler, 2006; Prasad and Goffeau, 2012). Este fenómeno permite a la célula sobrevivir ante la exposición a tóxicos, pero también es uno de los principales problemas que aparecen en tratamientos de quimioterapia en cáncer, infecciones fúngicas, o patologías neurológicas como epilepsia o depresión, entre otros, ya que disminuyen su eficiencia (Holohan et al., 2013; Prasad and Rawal, 2014; Paul and Moye-Rowley, 2014; Löscher and Potschka, 2005). Debido a la importancia que la MDR supone en los tratamientos médicos se ha investigado cómo revertir o minimizar los efectos de este fenómeno. Para ello se ha intentado desarrollar técnicas y estrategias enfocadas en el control de los transportadores implicados. En los tratamientos frente a cáncer las investigaciones se han centrado mayormente en las proteínas de la familia ABC, P-glicoproteína (P-gp codificada por MDR1/ABCB1), la proteína 2 asociada a resistencia multidroga (MRP2/ABCC2), y la proteína de resistencia de cáncer de pecho (BCRP/ABCG2) (Fletcher et al., 2016). Los métodos empleados para evitar el fenómeno MDR consisten en distintas estrategias, como inhibidores de P-gp, RNA de interferencia o moduladores epigenéticos, aunque todavía se están desarrollando (Robey et al., 2018; Chen et al., 2016; Li et al., 2016). Lo que parece observarse en todos los casos es que un mayor conocimiento de la regulación de estas proteínas es un paso necesario para poder controlar más específica y eficientemente su sobreexpresión y de esta forma el proceso MDR.

Además de su importancia en biomedicina este fenómeno de resistencia a compuestos químicos también afecta a otros sectores como la agricultura. Por un lado, supone una posible ventaja para desarrollar plantas acumuladoras de compuestos tóxicos en fitorremediación (Conte and Lloyd, 2011), pero por otro lado, este fenómeno reduce la efectividad de los tratamientos con herbicidas para eliminar las malas hierbas, con el 
Introducción

consiguiente problema para el medioambiente y económico en el sector agroalimentario (Teixeira et al., 2007; Cabrito et al., 2011).

\subsection{Proteínas ABC}

En el apartado anterior hemos comentado que entre los distintos mecanismos que contribuyen a la resistencia multidroga causantes de resistencia a tratamientos antifúngicos, de quimioterapia en cáncer, herbicidas, etc., la sobreexpresión de los transportadores de la familia $\mathrm{ABC}$ parece ser el más importante.

La superfamilia de poteínas ATP-binding cassette (ABC) son proteínas, muchas de las cuales, están conservadas de bacteria a eucariota superior (van Veen and Koning, 1997). Esta familia de proteínas está compuesta por más de 3000 miembros, de los que muchos comparten estructura y dominios similares (Jungwirth and Kuchler, 2006; Dean and Annilo, 2005). Estas proteínas están implicadas en muchos fenómenos biológicos, con gran variedad de funciones, desde el transporte transmembrana, a la regulación de distintos procesos celulares. En la levadura Saccharomyces cerevisiae encontramos 30 genes codificantes de proteínas ABC (Jungwirth and Kuchler, 2006), mientras que en humanos hay 51 según la Human Genome Organization (HUGO). Estos genes se encuentran divididos según la clasificación de la HUGO en siete subfamilias (ABCA a ABCG) en función de la similitud de sus secuencias aminoacídicas y filogenia, y estas subfamilias están representadas en el genoma de todos los organismos eucariotas (Dean and Annilo, 2005; Paumi et al., 2009). Además de esta clasificación, en el caso de Saccharomyces cerevisiae, estas proteínas ABC se pueden encontrar clasificadas en 5 subfamilias: PDR, MRP/CFTR, MDR, ALDp, y YEF3/RLI (Jungwirth and Kuchler, 2006; Paumi et al., 2009). En este trabajo nos centraremos en algunos transportadores de membrana plasmática pertenecientes a la subfamilia PDR (Pdr5, Pdr15, y Snq2), así como en Yor1, perteneciente a la subfamilia MRP. En la Figura 1 se muestran los transportadores $\mathrm{ABC}$ en S. cerevisiae. 


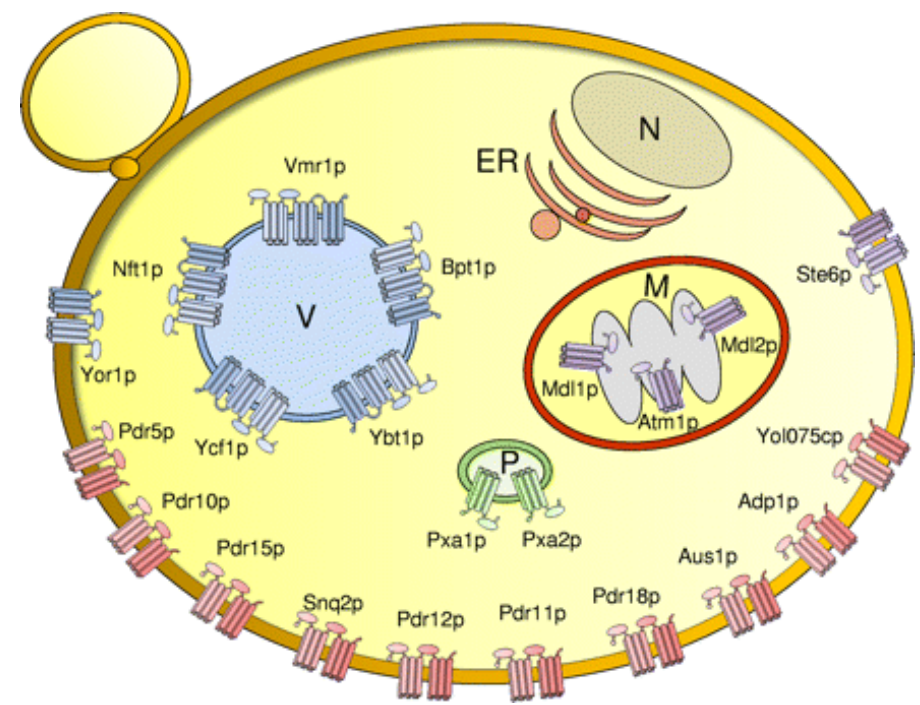

Figura 1. Localización celular de los transportadres de membrana ABC de S. cerevisiae. Las distintas subfamilias de transportadores se muestran en distintos colores: MDR (morado), MRP /CFTR (azul), ADLP (verde), y PDR (rojo). N: núcleo, ER: retículo endoplasmático, M: mitocondria, P: peroxisoma, V: vacuola. (Paumi et al., 2009)

La característica común más destacada de los transportadores de esta superfamilia es que comparten un dominio ATPasa altamente conservado (ABC), que se encarga de tomar e hidrolizar el ATP (Jungwirth and Kuchler, 2006; Paumi et al., 2009). Los transportadores $\mathrm{ABC}$, en general, se componen de dos tipos de dominios: un dominio de unión a nucleótido (NBD o nucleotide-binding domain) y un dominio transmembrana (TMD o transmembrane domain). La región transmembrana (TMD) contiene varios segmentos $\alpha$-hélice transmembrana (TMS), normalmente 6 , y es la parte más variable de los transportadores, que podría implicar la especificidad de sustrato y la gran variedad de compuestos reconocidos. Por el contrario, NBD se encuentra altamente conservado y se encarga de la hidrólisis del ATP a través de su ATPasa (Prasad and Goffeau, 2012; Jungwirth and Kuchler, 2006). Es decir, TMD reconoce y moviliza los sustratos a través de la membrana, mientras que NBD produce la energía necesaria para ello. Generalmente, estas proteínas contienen dos NBD citosólicos y dos (o incluso 3) regiones TMD en tandem $\left(\left(\mathrm{TMD}_{6}-\mathrm{NBD}\right)_{2}\right)$ para formar lo que se considera un transportador completo o "full-size", aunque también se pueden encontrar "medias" proteínas (Half-size) con sólo un NBD y un TMD, que funcionan como homo- o heterodímeros. Además, algunas de ellas pueden no contener dominio transmembrana (Prasad and Goffeau, 2012; Jungwirth and Kuchler, 2006). En las proteínas PDR encontramos una organización estructural reversa, es decir, el NBD precede a la region transmembrana $\left(\left(\mathrm{NBD}-\mathrm{TMD}_{6}\right)_{2}\right)$ (Figura 2). 


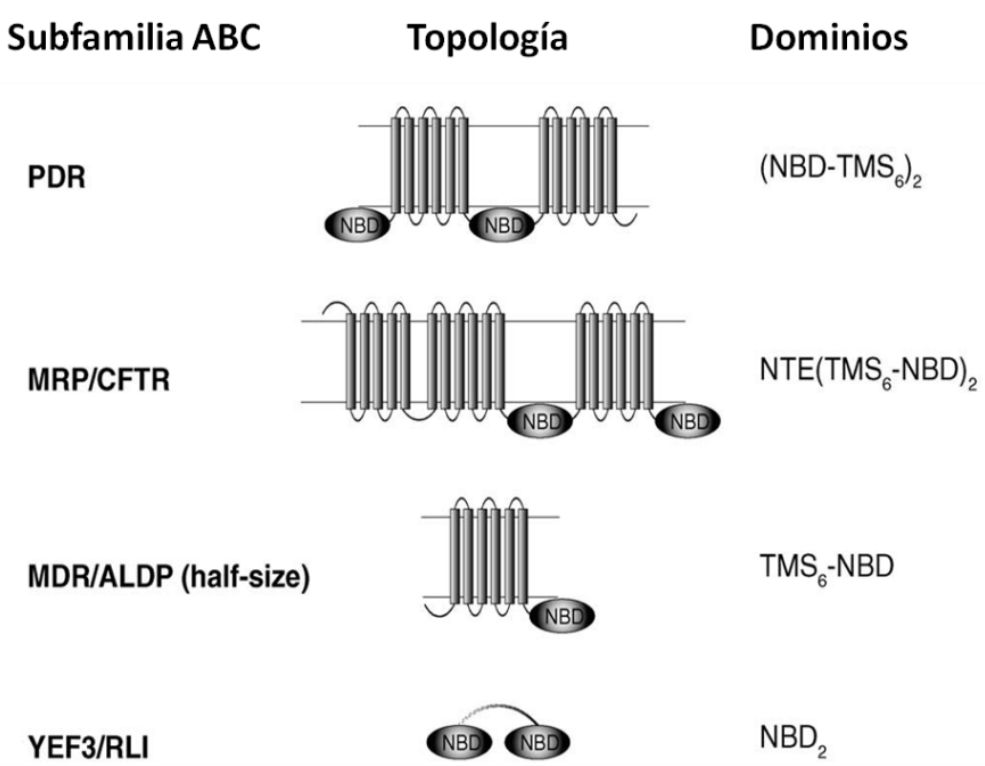

Figura 2. Topología y organización de dominios de las subfamilias de proteínas ABC de levadura. NBD: dominio de unión a nucleótidos; NTE: extensión N-terminal; TMS: segmento transmembrana. (Modificado de Jungwirth and Kuchler, 2006).

Conocer la estructura molecular de los sitios de unión al sustrato de los transportadores es importante tanto para entender la interacción proteína-sustrato como para desarrollar inhibidores específicos. A pesar de lo anterior, algunos estudios indican que la selección de sustrato en transportadores multidroga $\mathrm{ABC}$ eucarióticos no viene determinada únicamente por las características estructurales de los dominios transmembrana, sino también por su comportamiento dinámico (Ernst et al., 2010). Además, otro factor que hace variar la actividad de estos transportadores es la fina regulación a la que son sometidos por los factores de transcripción del sistema PDR. A continuación, describiremos en más detalle el sistema de resistencia pleiotrópica a drogas (PDR) de la levadura Saccharomyces cerevisiae.

\subsection{Sistema PDR en Saccharomyces cerevisiae.}

El sistema de resistencia pleiotrópica a drogas (PDR) de Saccharomyces cerevisiae confiere a la célula gran tolerancia a una amplia variedad de compuestos exógenos o xenobióticos así como de metabolitos tóxicos endógenos mediante su detoxificación. De esta forma, la célula es capaz de mantener un equilibrio apropiado para su correcto funcionamiento en condiciones fisiológicas normales como de sobrevivir a condiciones adversas. Pero esta capacidad protectora de la célula puede dar lugar al fenómeno de 
resistencia a múltiples drogas (MDR) o resistencia pleiotrópica a drogas (PDR) anteriormente comentado.

El sistema PDR está compuesto por transportadores ABC y MFS que se encargan de movilizar los compuestos a eliminar, así como de los factores de transcripción que se encargan de regularlos, y otras proteínas mediadoras (Figura 3). En este trabajo nos vamos a centrar en varios transportadores $\mathrm{ABC}$ y los factores de transcripción que parecen tener un papel en su regulación.

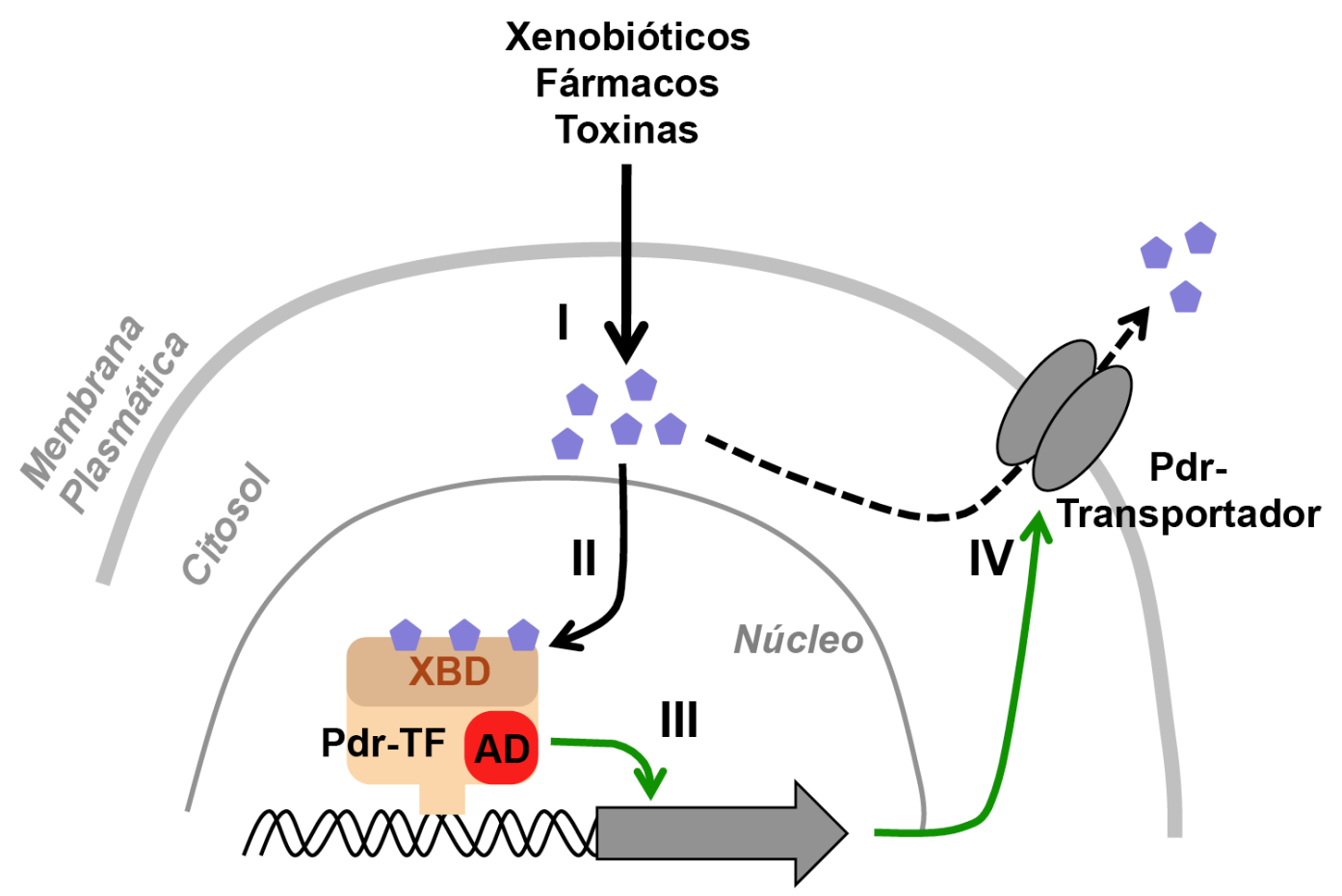

Figura 3. Esquema del sistema PDR (Pleiotropic Drug Resistance). (I) Diferentes compuestos con actividad xenobiótica entran al interior de la célula. (II) Los compuestos químicos son reconocidos de forma directa por unos factores de transcripción especializados (Pdr-TF = Factores de transcripción específicos para la respuesta PDR). Estos factores de transcripción contienen dominios especializados para el reconocimiento de xenobióticos $(\mathrm{XBD}=$ Xenobiotic Binding Domain) o para la activación de la transcripción (AD = Activation domain). (III) La unión del xenobiótico activa al factor Pdr-TF y se produce un incremento de la expresión de genes para transportadores específicos del sistema PDR (Pdr-Transportador). (IV) La actividad de estos transportadores en la membrana plasmática lleva a la expulsión del xenobiótico al exterior de la célula.

\subsubsection{Transportadores $\mathrm{ABC}$ del sistema de resistencia pleiotrópica a drogas (PDR).}

Los transportadores $\mathrm{ABC}$ de las células de levadura se encuentran repartidos en las distintas membranas de la célula, desde la membrana plasmática a los distintos orgánulos, como vacuola o mitocondria (Figura 1). Entre ellas se encuentran los 
Introducción

transportadores de la subfamilia PDR, localizados en la membrana plasmática y que participan principalmente, como su nombre indica, en la resistencia pleiotrópica a drogas (PDR). También en la membrana plasmática se encuentra localizado el transportador Yor1, perteneciente a la subfamilia MPR y componente del sistema PDR.

Los transportadores PDR mejor caracterizados son Pdr5 (Balzi et al., 1994) y Snq2 (Servos et al., 1993). Ambos transportadores se encuentran en la membrana plasmática y movilizan cientos de compuestos distintos, como antibióticos, fungicidas, esteroides y fármacos (Mahé et al., 1996; Kolaczkowski et al., 1998; Rogers et al., 2001; Ernst et al., 2005). Pdr5 y Snq2 tienen otras funciones importantes para la fisiología y mantenimiento de la célula además de participar en el proceso de resistencia multidroga, como la exportación de cationes (Miyahara et al., 1996) y mediar en el proceso de percepción de cuorum (quorum sensing) en poblaciones de levadura en cultivos de medio líquido (Hlavácek et al., 2009), mecanismo que permite la regulación de la expresión génica en respuesta a la densidad de población celular. Además, Pdr5 también participa en la translocación de fosfolípidos de la membrana plasmática (Kihara and Igarashi, 2004). Pdr5 funciona como homodímero, y sus niveles son más elevados durante la fase de crecimiento exponencial, y se reducen cuando las células entran en crecimiento diáuxico o hay falta de nutrientes (Mamnun et al., 2004).

Otros componentes PDR son los transportadores de la membrana plasmática Pdr10 y Pdr15 (Wolfger et al., 1997), homólogos de Pdr5 con una similitud del 66 y 74\% respectivamente (Wolfger et al., 2004). Pdr15 media el transporte de cloramfenicol y detergentes, y de forma opuesta a Pdr5, es más abundante cuando las células salen de la fase de crecimiento exponencial (Wolfger et al., 2004). Esto podría indicar una función relacionada pero no solapante en la detoxificación celular en diferentes fases de crecimiento o bajo ciertas condiciones metabólicas. Por su parte, Pdr10 se encarga de la correcta distribución y funcionamiento de algunas proteínas, como Chs3 (chitin sintasa) o del transportador Pdr12, de forma que, según se muestra en Rockwell et al.(2009) la disrupción de PDR10 aumenta los niveles de Pdr12 convirtiendo al mutante en resistente a sorbitol. El transportador Pdr12 también se encuentra en la membrana plasmática y está implicado en la resistencia a ácidos orgánicos débiles, y algunos de sus sustratos son benzoato, sorbato, ácido propiónico, y otros ácidos orgánicos producidos por la célula (Piper et al., 1998; Hatzixanthis et al., 2003). El resto de proteínas PDR están muy poco descritas. Pdr18 se ha relacionado con la resistencia a 
algunos herbicidas y tiene un papel fisiológico en la homeostasis de lípidos (Cabrito et al., 2011). Por su parte, Pdr11 y Aus1 parecen estar implicadas en la toma de esterol en levadura (Wilcox et al., 2002).

Por último, entre los transportadores responsables de la respuesta PDR se encuentra Yor1. Esta proteína forma parte de la subfamilia MPR y se encuentra localizada en la membrana plasmática. Yor1 está implicado en la tolerancia a oligomicina, cadmio, y un rango de xenobióticos tóxicos con grupos carboxilo (Cui et al., 1996; Decottignies et al., 1998). Pdr5 y Yor1 median la translocación de drogas similares en muchas ocasiones a pesar de sus diferencias topológicas, pero estudios in vitro han mostrado una actividad ATPasa 15 veces mayor en Pdr5 que en Yor1, indicando diferencias entre ambos transportadores a nivel regulatorio o de mecanismos (Decottignies et al., 1998). Ensayos posteriores con mutantes de deleción mostraron solapamiento en la especificidad del sustrato y actividad compensatoria entre Pdr5, Snq2 y Yor1, de forma que en los mutantes carentes de actividad de alguno de ellos y sometidos a sustratos específicos de estos transportadores los niveles de expresión de los otros se elevaban (Kolaczkowska et al., 2008). Estos estudios indicarían un elevado nivel de regulación en este proceso de respuesta a xenobióticos.

\subsubsection{Regulación genética del sistema PDR de levadura.}

La expresión de los transportadores PDR está controlada por varios factores de transcripción entre los que destacan Pdr1 (Balzi et al., 1987) y Pdr3 (Delaveau et al., 1994). Estos reguladores forman parte de la familia de factores de transcripción GAL4 que contiene un cluster de Zinc del tipo $\mathrm{Zn}_{2} \mathrm{Cys}_{6}$ de unión a ADN (DBD) (Kolaczkowska and Goffeau, 1999). Este DBD se encuentra en N-terminal, mientras que el dominio de activación (AD) se localiza en C-terminal. Entre ambos encontramos el dominio de unión a xenobióticos (XBD) y de reconocimiento por algunos reguladores de estos factores de transcripción. La región que incluye desde XBD a $\mathrm{AD}$ se conoce como dominio de transactivación en respuesta a xenobióticos (X-TAD) (Thakur et al., 2008; Paul and Moye-Rowley, 2014). A través de este dominio $\mathrm{X}-\mathrm{TAD}, \mathrm{Pdr} 1 / \mathrm{Pdr} 3$ son capaces de reconocer y unirse directamente a xenobióticos específicos, y a continuación activar la transcripción de los genes diana. Es decir, estos factores de transcripción Pdr activarían la transcripción de transportadores de drogas por unión directa al xenobiótico de forma similar a su ortólogo en mamíferos que son los 
Introducción

receptores nucleares, incluyendo $\mathrm{CAR}$ (constitutive androstane receptor) y $\mathrm{PXR}$ (pregnane X receptor) (Thakur et al., 2008; Wang et al., 2012; Yan and Xie, 2016).

Además, en estudios con diversos azoles se comprobó que la activación transcripcional de los genes diana de Pdr1/Pdr3 era mediada por la subunidad Gal11/Med15 del complejo coactivador Mediador que interactúa con la RNA polimerasa II. El AD del factor de transcripción se une directamente al dominio KIX de Gal11, altamente conservado (Thakur et al., 2008; Nishikawa et al., 2016). El uso de inhibidores de esta interacción bloqueando el dominio KIX se ha visto que vuelve a las células de levadura sensibles a estos azoles. Por lo tanto esta estrategia podría servir para aumentar la eficacia de los tratamientos en enfermedades infecciosas de hongos (Nishikawa et al., 2016).

Pdr1 y Pdr3 regulan la transcripción de los genes diana a través de sitios de unión en el promotor del gen diana, con secuencia 5'-CCGCGG-3', y que se conocen como elementos de resistencia pleiotrópica a drogas (PDRE - pleiotropic drug resistance elements) (Hellauer et al., 1996). Pdr1/Pdr3 pueden unirse a un solo sitio PDRE, pero para la activación del promotor es necesario almenos tres sitios PDRE (Kaltzmann et al., 1996). Pdr1 y Pdr3 pueden regular la expresión de los genes dianas tanto positiva como negativamente a través de los sitios PDRE y formar homo- o heterodímeros, lo que podría implicar la intervención de otros factores de transcripción en el proceso (Mamnun et al., 2002).

Pdr1 y Pdr3 regulan gran número de genes, como los codificantes de Pdr5, Pdr15, Snq2 y Yor1. Pero además de estos factores de transcripción, hay otros que también forman parte de su regulación. Entre los reguladores que participan en la respuesta PDR junto con Pdr1 y Pdr3, se encuentran Stb5 (Akache and Turcotte, 2002), Yrr1 (Cui et al., 1998), y dos homólogos parálogos de éste, Yrm1 (Lucau-Danila et al., 2003) y Pdr8 (Hikkel et al., 2003). En la Figura 4 se muestra un esquema de este sistema de regulación PDR. 


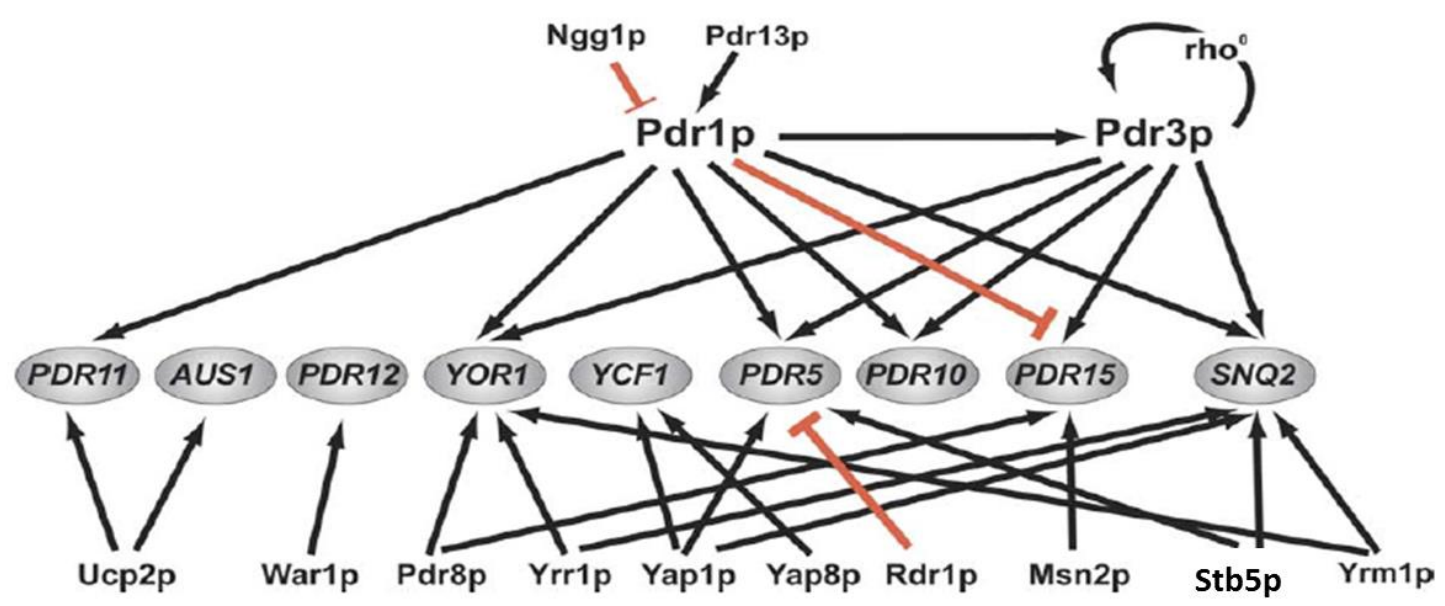

Figura 4. Esquema de la regulación del sistema PDR de levadura. Los genes en la línea central representan los genes diana de los reguladores transcripcionales. Las líneas muestran la regulación negativa (rojo) y positiva (negro). (Jungwirth and Kuchler, 2006)

PDR5 está regulado positivamente por Pdr1 y Pdr3 y negativamente por el factor de transcripción Rdr1, que forma heterodímeros con Pdr1 o Pdr3 compitiendo para unirse a los elementos PDRE (Hellauer et al., 2002).

PDR15 está regulado por Pdr1, Pdr3 y Pdr8 (Hikkel et al., 2003), pero además, su expresión está asociada a la respuesta general a estrés, por lo que se induce ante shock osmótico y térmico, falta de nutrientes y ácidos débiles, bajo el control de Msn2, ya que en el promotor de PDR15 se encuentran elementos de respuesta general a estrés (STRE) (Wolfger et al., 2004).

SNQ2 y YOR1 están regulados por Pdr1, Pdr3 e Yrr1, que sólo forma homodímeros (Cui et al., 1998; Zhang et al., 2001) y reconoce elementos muy similares pero distintos de PDRE (Le Crom et al., 2002). En el caso de $S N Q 2$, también puede ser regulado por el factor Stb5, que forma un heterodímero con Pdr1, y está implicado en la respuesta a estrés oxidativo (Akache and Turcotte, 2002; Larochelle et al., 2006).

Anteriormente hemos comentado que los factores de transcripción Pdr activan la transcripción de los genes de los transportadores tras unión directa con los xenobióticos, pero además, están regulados por otros factores de transcripción. Pdr1 es regulado positivamente por las proteínas Ssz1 y Zuo1 (Prunuske et al., 2012). Pdr3 es regulado por Pdr1, pero al igual que Yrr1 es capaz de autorregularse a través de los sitios PDRE de sus propios promotores (Delahodde et al., 1995). Además, Yrr1 puede ser inducido 
Introducción

por la actividad de Pdr1/Pdr3 (Zhang et al., 2001) e inhibido por el factor de transcripción Yrm1, aunque, en ausencia de Yrr1, Yrm1 activa la transcripción de genes regulados por éste (Lucau-Danila et al., 2003). Por último, se ha sugerido que Stb5 podría autorregularse, ya que se une a su propio promotor (Akache et al., 2004).

Yap1 también ha sido relacionado con la respuesta multidroga por participar en la resistencia a cicloheximida (Leppert et al., 1990), aunque estos efectos suceden mayormente con su sobreexpresión o cuando las drogas actúan a través de mecanismos de oxidación (Teixeira et al., 2008)

\section{Micotoxinas.}

Las micotoxinas son pequeñas moléculas tóxicas producidas por una gran variedad de hongos filamentosos y que abarcan varias clases de metabolitos secundarios sin una estructura química o modo de acción común (Bennett and Klich, 2003). Estos productos naturales dañinos de los mohos contaminan los alimentos y los piensos en todo el mundo con terribles consecuencias económicas, ya que afectan a la mayoría de los cultivos de alimentos básicos como maíz, trigo y arroz (Marroquin-Cardona et al., 2014; Moretti et al., 2013). Más allá de las pérdidas económicas, las micotoxinas tienen un impacto severo en el bienestar humano (Wu et al., 2014). Sus propiedades toxicológicas y sus posibles efectos sobre la salud han sido ampliamente estudiados y relacionados con algunas enfermedades, aunque es muy difícil demostrar el vínculo entre la exposición a la toxina y el inicio de los síntomas en la mayoría de los casos.

Las micotoxinas son liberadas por algunos hongos en la naturaleza por razones poco conocidas, y aunque se ha aceptado que la síntesis y secreción de toxinas median la virulencia patógena de los microorganismos en las plantas, las dianas moleculares y las estrategias para lograrlo aún no se han determinado en el caso de las micotoxinas (Mobius and Hertweck, 2009). Se han hecho considerables esfuerzos para comprender los mecanismos moleculares de las micotoxinas que causan daño celular y toxicidad (Doi and Uetsuka, 2014; Escriva et al., 2015; Vettorazzi et al., 2014). Aunque es importante comprender la base molecular de la acción de las micotoxinas en animales, estos enfoques son a menudo difíciles de llevar a cabo porque la relación dosis-efecto depende de muchos parámetros diferentes (Escriva et al., 2015). Como alternativa, los mecanismos fundamentales de toxicidad para cada micotoxina se pueden revelar de manera eficiente en cultivos celulares de células eucariotas inferiores como levadura. 
Las ocratoxinas son un pequeño grupo de micotoxinas producidas por las especies Aspergillus y Penicillium, con ocratoxina A (OTA) como compuesto principal, que se encuentra en una amplia gama de materias primas y alimentos procesados (Wang et al., 2016). La OTA es nefrotóxica, carcinogénica y un teratógeno potente cuando se prueba en diferentes modelos de mamífero, y por lo tanto, es un riesgo potencial para la salud humana (Koszegi and Poor, 2016). Varios autores respaldan que el modo de acción de OTA implica la formación de aductos de ADN covalentes (Faucet et al., 2004; Mantle et al., 2010; Pfohl-leszkowicz and Manderville, 2012) y el aumento de especies reactivas de oxígeno (Rahimtula et al., 1988; Sorrenti et al., 2013), y por lo tanto, estas actividades podrían explicar la actividad genotóxica y mutagénica de la OTA.

La co-ocurrencia de OTA con citrinina (CIT), otra micotoxina, ha sido frecuentemente reportada (Bragulat et al., 2008; Vrabcheva et al., 2000). CIT es producida por hongos filamentosos de los géneros Penicillium, Aspergillus y Monascus, y contamina los mismos alimentos básicos que OTA (Ostry et al., 2013). Los hongos como Penicillium verrucosum son capaces de producir tanto OTA como CIT, sin embargo, diferentes condiciones ambientales podrían favorecer la producción de una micotoxina sobre la otra (Schmidt-Heydt et al., 2012; Schmidt-Heydt et al., 2015; Stoll et al., 2013). Mucho menos se sabe sobre los mecanismos de toxicidad de CIT, sin embargo, se ha demostrado que también es una eficiente nefrotoxina (Flajs and Peraica, 2009). Varios grupos han contribuido a la identificación de posibles mecanismos moleculares de la toxicidad de CIT, encontrando, entre otras consecuencias, el aumento de estrés oxidativo relacionado con alteraciones de la función mitocondrial, y la inducción de la apoptosis (Bouslimi et al., 2008; Chan, 2007; Kumar et al., 2014; Kumar et al., 2011; Pascual-Ahuir et al., 2014; Ribeiro et al., 1997; Yu et al., 2006). Se ha propuesto que la concurrencia de ambas toxinas da lugar a efectos sinérgicos, sin embargo, no se han llegado a conclusiones claras (Follmann et al., 2014; Klaric et al., 2013).

\section{Antecedentes.}

Las células de levadura son un modelo excelente para estudiar la respuesta adaptativa a distintos estreses, como la exposición a distintos químicos y xenobióticos. Esto es debido a que los organismos unicelulares tienen la necesidad de desarrollar sistemas de defensa para la detoxificación muy eficientes y que se activen de forma rápida, ya que están totalmente expuestas al entorno (Dos Santos et al., 2012). El análisis de expresión 
Introducción

génica se ha convertido en una herramienta valiosa para tratar de comprender los mecanismos moleculares en respuesta a agentes tóxicos, incluidas micotoxinas (Afshari et al., 2011), y el modelo de levadura es particularmente importante en estudios en toxigenómica (Yasokawa and Iwahashi, 2010).

En estudios anteriores, cuantificamos la respuesta de adaptación transcripcional inmediata a CIT en levadura empleando reporteros del sistema luciferasa (PascualAhuir et al., 2014). El sistema de luciferasa desestabilizada nos permite cuantificar la expresión génica inducida por un estrés de forma sensible y en tiempo real en células vivas de levadura (Rienzo et al., 2012). Además, podemos estudiar simultáneamente distintas condiciones de uno o varios compuestos al obtener sus perfiles dosis-respuesta (Dolz-Edo et al., 2013).

Una forma de estudiar la respuesta de adaptación transcripcional a xenobióticos en conjunto son los análisis transcriptómicos. Se han realizado distintos enfoques transcriptómicos con OTA usando diferentes líneas celulares y sistemas de modelos de mamíferos (Arbillaga et al., 2007; Hibi et al., 2013; Hundhausen et al., 2008; MarinKuan et al., 2006). La comparación de los datos genómicos no produce un patrón uniforme de genes desregulados, por lo que parece que la variabilidad de la respuesta transcriptómica inducida por OTA podría ser una consecuencia del rango de condiciones experimentales así como el contexto celular (Vettorazzi et al., 2013). A diferencia de OTA, los datos de perfil genómico para el tratamiento de CIT son escasos, sin embargo, la aplicación de enfoques de microarrays de levadura ha identificado la defensa antioxidante como uno de los modos primordiales de detoxificación en exposición a CIT (Iwahashi et al., 2007). Una parte primordial de la planificación del ensayo transcriptómico es la selección de las condiciones de inducción óptimas ya que la respuesta transcripcional a las micotoxinas parece ser transitoria y dependiente de la dosis, como se observó previamente con CIT (Pascual-Ahuir et al., 2014).

En la respuesta adaptativa a xenobióticos en levadura participa un grupo de proteínas que forman el denominado sistema PDR (pleiotropic drug resistance). Aunque existe mucha literatura sobre los distintos factores de transcripción y transportadores multidroga que componen este sistema, todavía no está claro como se produce la especificidad en la respuesta a tan variado número de moléculas. Una estructura regulatoria muy bien definida parece ser fundamental, por lo que los factores de 
transcripción Pdr podrían ser clave, ya que parece que son capaces de detectar directamente las moléculas a eliminar (Thakur et al., 2008). Por ello, desarrollar herramientas para descrifar las distintas sensibilidades del sistema PDR en levadura puede ser de gran utilidad.

En este trabajo, vamos a estudiar cuáles son los mecanismos de toxicidad de las micotoxinas CIT y OTA, y tratar de comprender en más profundidad la red de regulación del sistema PDR. 

OBJETIVOS 

El objetivo general de este trabajo es estudiar la implicación de las proteínas pertenecientes al sistema PDR de la levadura Saccharomyces cerevisiae en la respuesta adaptativa a xenobióticos, como las micotoxinas citrinina y ocratoxina A. Para lograr este objetivo general desarrollamos varios objetivos específicos:

1. Identificar y comparar los mecanismos de toxicidad de las micotoxinas citrinina y ocratoxina A.

2. Caracterizar la activación transcripcional dosis-dependiente de transportadores multidroga en respuesta a diferentes xenobióticos.

3. Comparar de forma cuantitativa las sensibilidades y selectividades de los factores de transcripción involucrados en la respuesta multidroga. 

MATERIALES $Y$ MÉTODOS 



\section{Cepas y condiciones de cultivo de bacterias.}

En este trabajo se utilizó la cepa DH5a (F'Ф80dlacZAM15 $\triangle$ (lacZYA-argF) deoRrecA1 endA1 hsdR17(rKm mK $K^{+}$phoA supE44 $\left.\lambda^{-1} t h i^{-I}\right)$ de Escherichia coli para la propagación y posterior aislamiento de los plásmidos.

El medio de cultivo empleado para su crecimiento fue el medio LB (Luria Bertani), cuya composición es $0,5 \%$ extracto de levadura, $1 \%$ triptona y $1 \% \mathrm{NaCl}$, disuelto en agua MiliQ y autoclavado a $121^{\circ} \mathrm{C}$ durante 20 minutos. En el caso de los medios sólidos de LB se adicionó un $2 \%$ de agar bacteriológico. Además, se utilizaron medios selectivos LB con adición de ampicilina $(50 \mu \mathrm{g} / \mathrm{ml})$ o kanamicina $(100 \mu \mathrm{g} / \mathrm{ml})$ para la selección de plásmidos.

Los cultivos de bacterias se incubaron durante toda la noche a $37^{\circ} \mathrm{C}$, manteniendo una agitación constante (200 rpm) en el caso de los cultivos en medio líquido.

\section{Cepas y condiciones de cultivo de levaduras.}

Las diferentes cepas de Saccharomyces cerevisiae empleadas en este trabajo se muestran en las tablas suplementarias 1 a 4 . Los medios utilizados para crecer las cepas de levadura fueron el medio completo YPD (Yeast Extract Peptone Dextrose) y el medio mínimo SD (Synthetic Dextrose), suplementados con aminoácidos o antibiótico en función de las necesidades.

El medio YPD está compuesto de 1\% extracto de levadura, 2\% peptona bacteriólogica y $2 \%$ glucosa, diluido en agua MiliQ y autoclavado a $121^{\circ} \mathrm{C}$ durante 20 minutos. Se suplementó con $200 \mu \mathrm{g} / \mathrm{ml}$ de geneticina (G418) para seleccionar mutantes de deleción a los que se integró el marcador de resistencia a kanamicina.

El medio de cultivo SD está compuesto por 0,7\% yeast nitrogen base (YNB), 2\% glucosa, y 50mM ácido succínico $\mathrm{pH}=5,5$ ó 3 (ajustado con Tris base), diluido en agua MiliQ y autoclavado a $121^{\circ} \mathrm{C}$ durante 20 minutos. Además, a este medio se le adicionaron aminoácidos y bases nitrogenadas $(25 \mu \mathrm{g} / \mathrm{ml}$ adenina, $100 \mu \mathrm{g} / \mathrm{ml}$ histidina, $100 \mu \mathrm{g} / \mathrm{ml}$ leucina, $100 \mu \mathrm{g} / \mathrm{ml}$ metionina, $50 \mu \mathrm{g} / \mathrm{ml}$ triptófano y $25 \mu \mathrm{g} / \mathrm{ml}$ uracilo) en función de la selección por auxotrofía a utilizar.

En los medios sólidos, en todos los casos, se suplementó 2\% agar bacteriológico. Las células se incubaron a $28^{\circ} \mathrm{C}$, y en el caso de los cultivos líquidos, en agitación constante a $200 \mathrm{rpm}$. 


\subsection{Disrupción génica.}

Los mutantes de deleción $\Delta$ gal4 (gal4::kan), $\Delta p d r 1$ (pdr1::his3) y $\Delta p d r 3$ (pdr3::his3) se obtuvieron a partir de las cepas W303-1A, $\Delta p d r 1$ (pdr1::kan) y $\Delta p d r 3$ (pdr3::kan), respectivamente, mediante la adaptación del sistema loxP de disrupción de genes descrito por Güldener et al. (1996). A continuación se muestra un esquema de trabajo de esta técnica (Figura 5).
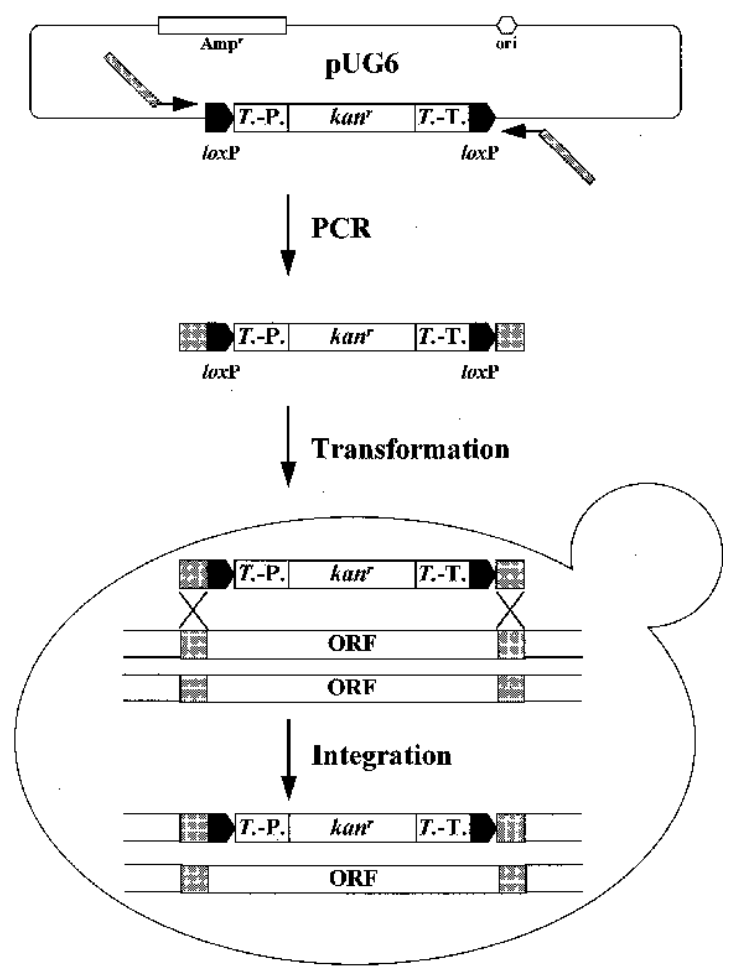

Figura 5. Deleción de genes de levadura con el marcador $\operatorname{kan}^{\mathbf{r}}$. A partir del plásmido pUG6 se obtiene y amplifica mediante la técnica PCR el cassette de disrupción génica. Para ello se utilizan cebadores con 45pb complementarias a la secuencia diana del gen a delecionar y 19-22pb complementarias a la región contigua a los sitios loxP del módulo de disrupción. El producto de PCR es utilizado para transformar las células de levadura, dónde, por recombinación homóloga, el cassette se integra en el genoma, produciéndose la deleción del gen a estudio. (Güldener et al., 1996)

\subsubsection{Construcción del cassette de disrupción génica.}

En el mutante $\Delta$ gal4 (gal4::kan) se utilizó el plásmido pUG6 como ADN molde para la obtención del cassette de disrupción TS-loxP-kanMX-loxP-TS, el cual se compone, en los extremos, de dos secuencias complementarias al gen diana a delecionar (TS) junto a los sitios loxP, los cuales flanquean el gen $\operatorname{kan}^{\mathrm{r}}$ que confiere resistencia al antibiótico G418, con su correspondiente promotor y terminador (TEF2). En el caso de $\Delta p d r 1$ (pdr1::his3) y $\Delta p d r 3$ (pdr3::his3) se utilizó el plásmido pAG413 como template para la obtención del fragmento de ADN a integrar (TS(kan)-HIS3-TS(kan)), el cual contiene, en los extremos, secuencias complementarias al marcador de resistencia a kanamicina (kanMX), junto al gen de histidina (HIS3). 
La amplificación del fragmento de ADN se realizó mediante la reacción en cadena de la polimerasa (PCR). Los oligonucleótidos utilizados tienen una secuencia de 19-22 nucleótidos en 3' complementaria a la región del plásmido flanqueante a los sitios loxP/HIS3 y unos 45 nucleótidos en 5' complementarios a los sitios upstream o downstream correspondientes a la secuencia del gen diana. Cada reacción se realizó por duplicado, con un volumen final de $100 \mu$, se añadió $1 \mu \mathrm{l}$ de cada uno de los cebadores (primers) a $10 \mathrm{pmol} / \mu \mathrm{l}, 10 \mu \mathrm{l}$ de dNTPs a $2 \mathrm{mM}, 1 \mu \mathrm{l}(10 \mathrm{ng})$ de ADN molde, $10 \mu \mathrm{lde}$ tampón de PCR 10x comercial (Thermo Scientific), $10 \mu \mathrm{lde} \mathrm{MgCl}_{2}$ a $25 \mathrm{mM}$ (Thermo Scientific), $1 \mu \mathrm{l}$ de enzima TrueStart Hot Start Taq DNA Polymerase a 1U/ $\mu 1$ (Thermo Scientific) y $66 \mu \mathrm{l}$ de $\mathrm{H}_{2} \mathrm{O}$. Las condiciones de amplificación fueron: un paso de desnaturalización, de 5 minutos a $94^{\circ} \mathrm{C} ; 35$ ciclos de amplificación (desnaturalización durante $30 \mathrm{seg}$ a $94^{\circ} \mathrm{C}$, alineamiento durante $30 \mathrm{seg}$ a $53^{\circ} \mathrm{C}$, y extensión durante 2 min a $72^{\circ} \mathrm{C}$ ); y un paso final de elongación de $10 \mathrm{~min}$ a $72^{\circ} \mathrm{C}$.

Para comprobar la correcta formación y amplificación del cassette de disrupción se corrió un gel de agarosa al $1 \%$.

\subsubsection{Transformación de levadura con construcción de disrupción.}

Los amplicones obtenidos fueron purificados con el kit QIAquick PCR Purification (Qiagen) y utilizados para la transformación de las células de levadura con las técnicas descritas en los apartados correspondientes, aunque en la transformación se emplearon 1-2 $\mu \mathrm{g}$ de ADN y, para permitir la recombinación homóloga, las células se incubaron durante $3 \mathrm{~h}$ a $28^{\circ} \mathrm{C}$ en medio no selectivo (YPD) previamente a la inoculación en placa con medio selectivo YPD+G418 ( $\Delta$ gal4)/SD-his $(\Delta p d r 1$ y $\Delta p d r 3)$.

\subsubsection{Verificación de la deleción.}

Las colonias obtenidas fueron aisladas y se extrajo su ADN genómico para utilizarlo como molde en una nueva PCR de verificación. En este caso, los cebadores empleados eran específicos del promotor del gen delecionado y del cassette. Obteniendo un producto de 400-500 pb. Además, se utilizó un control positivo para comprobar que el ADN genómico se encontraba en buen estado. En este caso la reacción tenía un volumen final de $50 \mu \mathrm{l}$, se añadió $1 \mu \mathrm{l}$ de cada uno de los primers a $100 \mathrm{pmol} / \mu \mathrm{l}, 5 \mu \mathrm{l}$ de dNTPs a 2 mM, $1 \mu \mathrm{l}$ de ADN molde, $5 \mu \mathrm{l}$ de tampón de PCR 10x comercial (Biotools) con $\mathrm{MgCl}_{2}, 1 \mu \mathrm{l}$ de Taq polimerasa a $1 \mathrm{U} / \mu \mathrm{l}$ (Biotools) y $36 \mu \mathrm{lde} \mathrm{H}_{2} \mathrm{O}$. Las condiciones de amplificación fueron: un paso de desnaturalización, de 5 minutos a $94^{\circ} \mathrm{C} ; 30$ ciclos de amplificación (desnaturalización durante $30 \mathrm{seg}$ a $94^{\circ} \mathrm{C}$, alineamiento durante 30 
sega $53^{\circ} \mathrm{C}$, y extensión durante $1 \mathrm{~min}$ y $30 \mathrm{seg}$ a $72^{\circ} \mathrm{C}$ ); y un paso final de elongación de 7 min a $72^{\circ} \mathrm{C}$.

De nuevo se comprobó si la integración había sido correcta mediante un gel de agarosa al $1 \%$.

En el caso de $\Delta p d r 1$ y $\Delta p d r 3$, al tratarse de un cambio de marcador de selección, kanMX a HIS3, se verificó este intercambio por selección de las colonias que crecieron en el medio selectivo SD-his pero no lo hicieron en placas de YPD+G418.

\section{Plásmidos y construcciones.}

Los plásmidos empleados en este trabajo fueron pUG6, pAG413 y pGBKT7 con diversas construcciones, mostradas en la tabla suplementaria 5. A partir de estos tres plásmidos se realizaron tres tipos de construcciones, descritas más adelante.

El plásmido pUG6-lucCP $\mathbf{P}^{+}$-Cyc1T-KAN fue empleado para obtener las cepas con las construcciones luciferasa integrativas (construcción 1). El plásmido pAG413-CYC1 $\Delta$ lucCP ${ }^{+}$se utilizó tanto para la construcción 2 (pAG413-3xPDRE-lucCP ${ }^{+}$) como en la construcción 3 (pAG413-GAL1 UAS-lucCP $^{+}$). Por último, pGBKT7-ADH1p-Gal4 DBD- $^{-}$

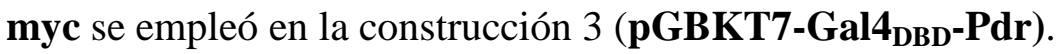

Todas las construcciones desarrolladas en este trabajo están basadas en el sistema de luciferasa desestabilizada (Rienzo et al., 2012), explicada en el apartado 8, y cuyo detalle del gen de luciferasa desestabilizada se muestra en la Figura 6.

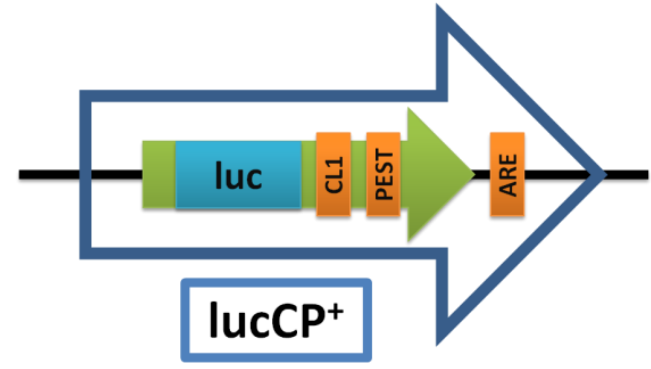

Figura 6. Detalle del gen de luciferasa desestabilizada (lucCP${ }^{+}$). El gen de luciferasa desestabilizada (lucCP ${ }^{+}$) contiene, junto al gen de luciferasa de luciérnaga (luc), dos motivos de degradación proteica (CL1 y PEST) y de ARNm (ARE), de forma que no hay acumulación.

\subsection{Construcción 1: Fusión de los promotores PDR5, PDR15, SNQ2, y YOR1 con lucCP ${ }^{+}$en el genoma.}

La construcción 1 se obtuvo al integrar en el genoma de levadura un fragmento de ADN con el gen de luciferasa desestabilizada $\left(\operatorname{lucC} \mathrm{CP}^{+}\right)$y el marcador de resistencia a geneticina G418 $\left(\mathrm{Kan}^{\mathrm{r}}\right)$, con su correspondiente promotor y terminador (TEF2), en lugar del correspondiente gen de interés. Este fragmento se fusionó al promotor de los 
transportadores multidroga $P D R 5, P D R 15, S N Q 2$ y YOR1. En la Figura 7 se muestra un esquema de esta construcción.

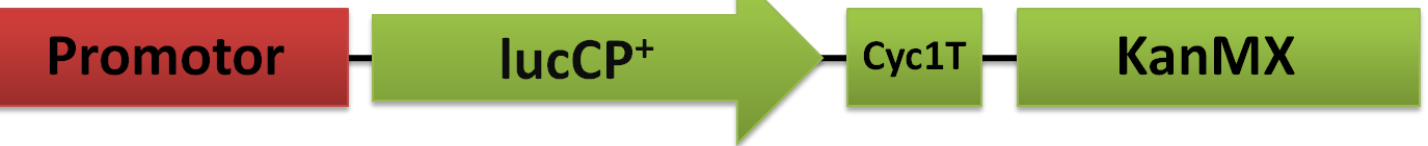

Figura 7. Esquema de la construcción 1. La construcción 1 se compone de un fragmento de ADN con el gen de luciferasa desestabilizada (lucCP ${ }^{+}$), el terminador artificial Cyc1 y el marcador de resistencia a geneticina G418 (KanMX). Este fragmento, al integrarse en el genoma, queda fusionado al promotor del gen diana.

Se empleó el plásmido pUG6-lucCP ${ }^{+}$-Cyc1T-KAN como template para obtener el fragmento de ADN con la construcción a integrar en el genoma. Para ello, se utilizó la misma técnica que se describe en el apartado anterior. En este caso, al tratarse de fragmentos mayores, el tiempo de extensión durante la amplificación fue de 4 minutos. Se muestra una representación del fragmento amplificado en la Figura 8.

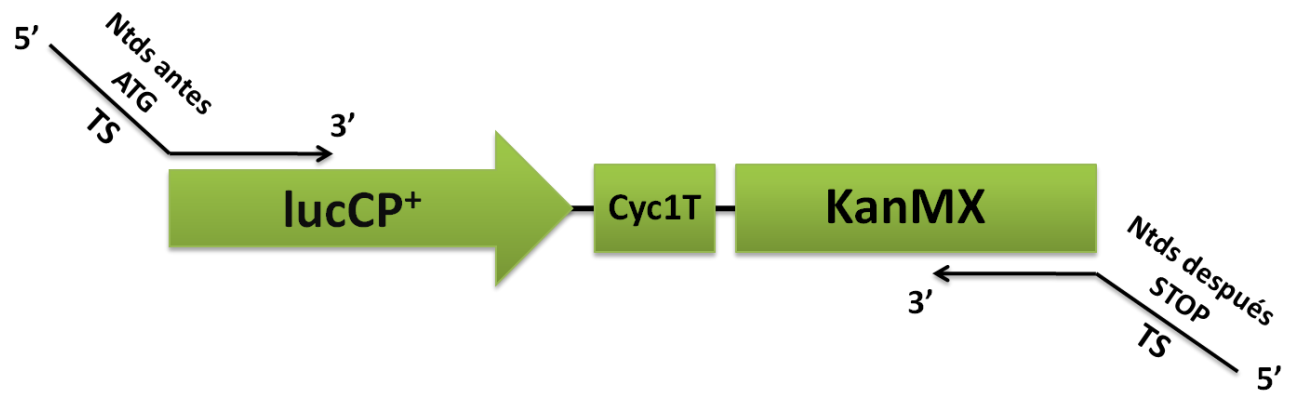

Figura 8. Cassette de integración. El fragmento de ADN con el gen de luciferasa desestabilizada (lucCP ${ }^{+}$), el terminador artificial Cyc1 y el marcador de resistencia a geneticina G418 (Kan ${ }^{\mathrm{r}}$ ) se amplifica utilizando cebadores complementarios en 3' a los extremos de la región del plásmido que queremos integrar y en 5', a la secuencia del gen diana (TS).

Una vez obtenido el fragmento de ADN se procedió a su purificación y transformación de las células de levadura según el procedimiento descrito anteriormente. Las colonias obtenidas se aislaron y se extrajo su ADN genómico para verificar la integración mediante PCR y gel de agarosa al 1\%, como en el apartado anterior.

\subsection{Construcción 2: pAG413-3xPDRE-lucCP ${ }^{+}$.}

La construcción 2 (3xPDRE-lucCP ${ }^{+}$) se obtuvo al fusionar 3 repeticiones del elemento PDR (PDRE), con secuencia 5'-CCGCGG-3', al gen de luciferasa desestabilizada en el plásmido pAG413-CYC1 $\Delta$-lucCP ${ }^{+}$. En la Figura 9 se muestra un esquema de esta construcción. 


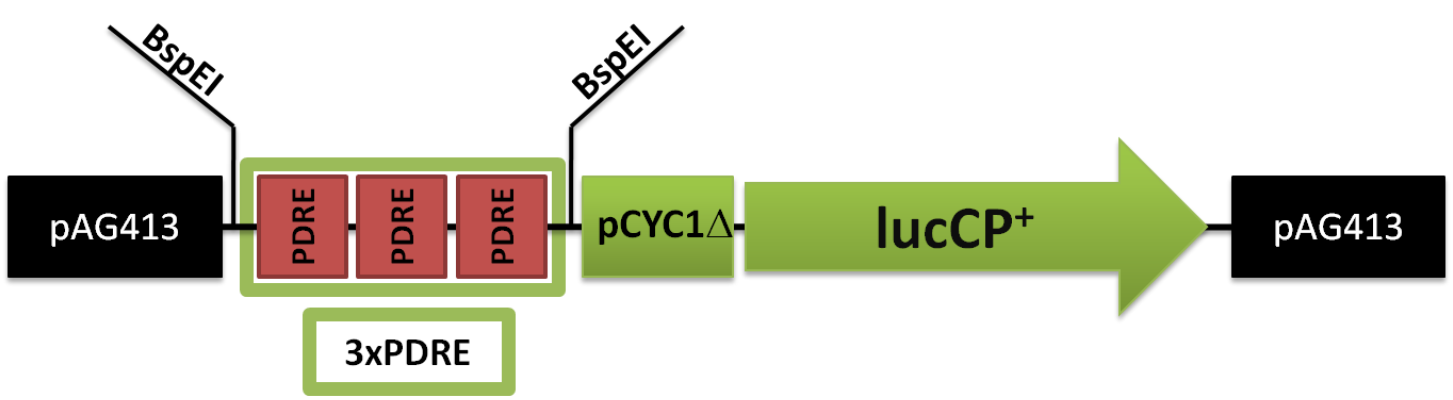

Figura 9. Esquema construcción 2 (pAG413-3xPDRE-lucCP ${ }^{+}$). La construcción 2 contiene, en el plásmido pAG413-CYC1 $\Delta$-lucCP ${ }^{+}, 3$ repeticiones del elemento PDR (3xPDRE), el promotor CYC1 $\Delta, \mathrm{y}$ el gen de luciferasa desestabilizada $\left(\operatorname{lucC} \mathrm{CP}^{+}\right.$). En la figura se muestra el sitio de corte de la enzima de restricción empleada (BspEI).

En primer lugar, se obtuvo el fragmento de ADN con las 3 repeticiones PDRE (3xPDRE) mediante hibridación $\left(5\right.$ minutos a $\left.95^{\circ} \mathrm{C}\right)$ de oligonucleótidos sintéticos fosforilados (BspEI-EcoRV-3xPdr1-1 y BspEI-EcoRV-3xPdr1-2). El plásmido pAG413-CYC1 $\Delta$-lucCP ${ }^{+}$se digirió con la enzima de restricción BspEI (Kpn2) durante 2 horas a $55^{\circ} \mathrm{C}$ y tratado con fosfatasa alcalina durante 1 hora a $37^{\circ} \mathrm{C}$ para evitar la recircularización del plásmido. A continuación, se purificó el vector digerido y desfosforilado con el kit QIAquick PCR Purification (Qiagen). La ligación entre vector e inserto se realizó empleando el kit Quick Ligation kit (New England Biolabs). El producto de ligación fue empleado en la transformación de bacterias DH5 $\alpha$ según el protocolo habitual. Las colonias obtenidas fueron cultivadas en tubos de precultivo con LB líquido suplementado con ampicilina, y se les extrajo y purificó el ADN plasmídico (minipreps) empleando el kit Nucleospin Plasmid (Macherey Nagel). A continuación, se verificó la inserción mediante digestión con EcoRV ( $1 \mathrm{~h}$ a $\left.37^{\circ} \mathrm{C}\right)$, ya que tenemos sitio de corte en inserto y vector, y visualización en gel de electroforesis al $1 \%$.

Las cepas de levadura se transformaron con el plásmido portador de la construcción $3 \times \mathrm{XDRE}-\mathrm{ucCP}^{+}$según la técnica habitual y se seleccionaron las colonias positivas en medio sólido SD-his.

\subsection{Construcción 3: Sistema binario GAL1 $1_{\mathrm{UAS}}-\mathrm{lucCP}^{+}$y $\mathrm{Gal}_{\mathrm{DBD}^{-P d r}}$.}

La construcción 3 se compone de dos plásmidos (pAG413-GAL1 UAs-lucCP $^{+}$y pGBKT7-Gal4 ${ }_{\text {DBD }}$-Pdr).

El vector pAG413-GAL1 UAS-lucCP $^{+}$se obtuvo fusionando la parte del promotor GAL1 que contiene las secuencias UAS (Upstream Activation Sequence), específicas para 
unión de Gal4, al gen de luciferasa desestabilizada (lucCP ${ }^{+}$) en el plásmido pAG413CYC1 $\Delta$-lucCP ${ }^{+}$. Las secuencias UAS son potenciadores o enhancers en la activación de la transcripción del gen. En este caso, encontramos 4 regiones UAS con secuencia CGG(11N)CCG. En la Figura 10 se muestra un esquema de este vector.

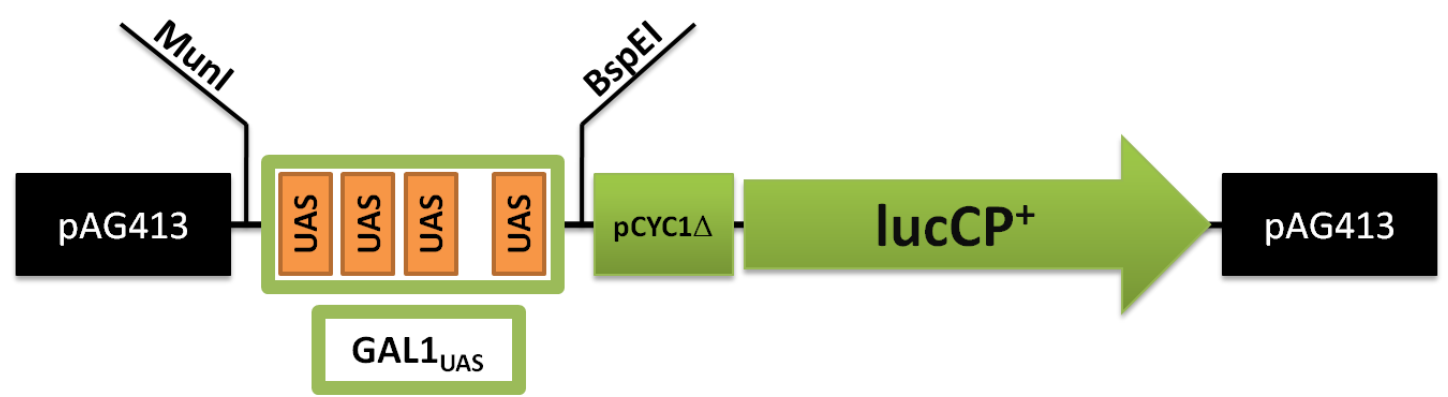

Figura 10. Esquema pAG413-GAL1 UAS $^{-l u c C P}{ }^{+}$. El vector pAG413-GAL1 UAS - lucCP $^{+}$contiene, en el plásmido pAG413-CYC1 $\Delta$-lucCP ${ }^{+}$, un inserto con la región del promotor GAL1 donde se encuentran las 4 secuencias UAS específicas de unión de Gal4 (GAL1 $1_{\mathrm{UAS}}$ ), el promotor CYC1 $\Delta$, y el gen de luciferasa desestabilizada $\left(\right.$ lucCP$\left.^{+}\right)$. En la figura se muestra los sitios de corte de las enzimas de restricción empleadas (MunI y BspEI).

El fragmento de ADN con las secuencias UAS se obtuvo a partir de ADN genómico de la cepa de levadura W303-1A. Para ello, se amplificó el inserto empleando cebadores que incorporaban en sus extremos 5' sitios de corte para las endonucleasas MunI (Gal1UAS-MunI) y BspEI (Gal1UAS-Kpn2I). La reacción de amplificación tenía un volumen final de $100 \mu \mathrm{l}$, se añadió $1 \mu \mathrm{l}$ de cada uno de los primers a $100 \mathrm{pmol} / \mu 1,10 \mu 1$ de dNTPs a $2 \mathrm{mM}, 1 \mu \mathrm{l}$ de ADN molde, $10 \mu \mathrm{l}$ de tampón de PCR 10x comercial (Biotools) con $\mathrm{MgCl}_{2}, 1 \mu \mathrm{l}$ de Taq polimerasa a $1 \mathrm{U} / \mu \mathrm{l}$ (Biotools) y $76 \mu \mathrm{lde} \mathrm{H}_{2} \mathrm{O}$. Las condiciones de amplificación fueron: un paso de desnaturalización, de 5 minutos a $94^{\circ} \mathrm{C} ; 35$ ciclos de amplificación (desnaturalización durante $30 \mathrm{seg}$ a $94^{\circ} \mathrm{C}$, alineamiento durante $30 \mathrm{seg}$ a $53^{\circ} \mathrm{C}$, y extensión durante $1 \min$ a $72^{\circ} \mathrm{C}$ ); y un paso final de elongación de 7 min a $72^{\circ} \mathrm{C}$. Se comprobó si la amplificación había sido correcta mediante un gel de agarosa al $1 \%$ y se purificó el amplicón con el kit QIAquick PCR Purification (Qiagen).

El inserto y el plásmido pAG413-CYC1 $\Delta$-lucCP ${ }^{+}$se digirieron con las enzimas de restricción MunI y BspEI (Kpn2) durante 2 horas a $55^{\circ} \mathrm{C}(\mathrm{BspEI})$ y overnight $(\mathrm{o} / \mathrm{n})$ a $37^{\circ} \mathrm{C}$ (ambas). A continuación, se purificaron inserto y vector con QIAquick PCR Purification (Qiagen) y Geneclean ${ }^{\circledR}$ Turbo Kit (QBiogene, Inc), respectivamente.La ligación entre vector e inserto se realizó empleando Rapid DNA Ligation Kit (Thermo 
Scientific). El producto de ligación fue empleado en la transformación de bacterias DH5 $\alpha$ competentes según el protocolo habitual. Las colonias obtenidas fueron cultivadas en tubos de precultivo con LB líquido suplementado con ampicilina, y se les extrajo y purificó el ADN plasmídico empleando el kit NucleoSpin Plasmid (Macherey Nagel). A continuación, se verificó la inserción mediante digestión con MunI y BspEI, y por PCR empleando el cebador Gal1UAS correspondienteal inserto y un cebador interno del gen luciferasa (LucSeqRev) con el extremo 3' hacia el inicio del gen. De nuevo, se visualizó con gel de electroforesis al $1 \%$.

Por su parte, el vector pGBKT7-Gal4 $_{\text {DBD }}$-Pdr se consiguió al clonar los distintos factores de transcripción PDR, sin el extremo N-terminal con el dominio de unión a

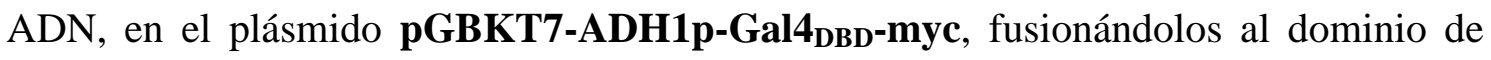
unión a ADN de Gal4 (Gal4 $\mathrm{DBD})$, como se muestra en la Figura 11.

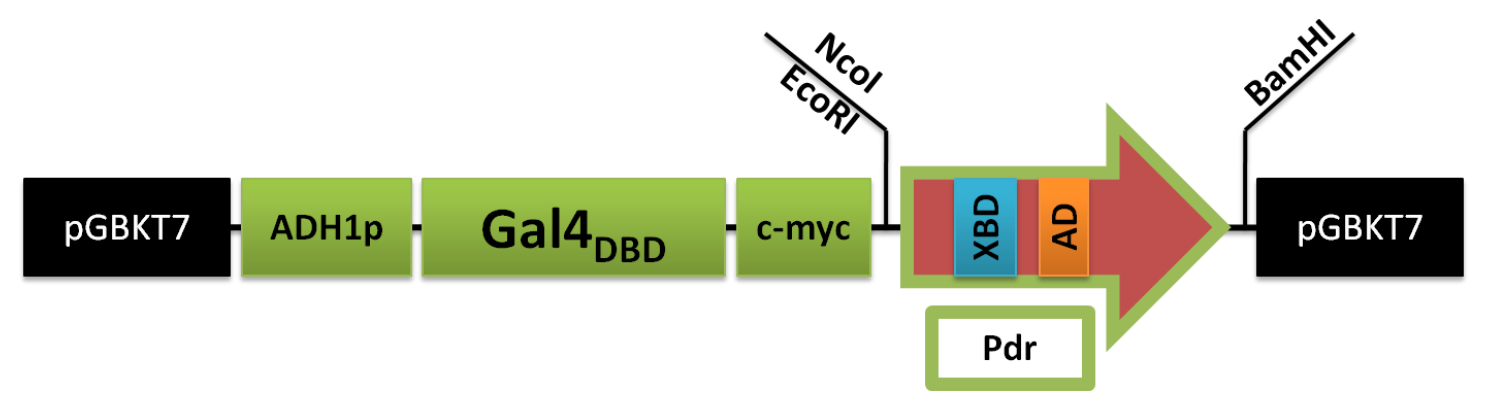

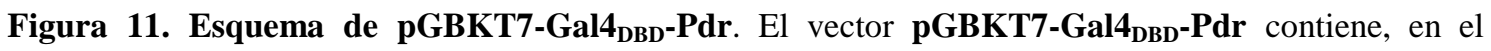

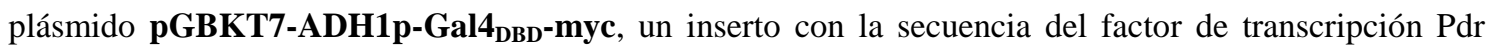
correspondiente con las regiones de unión a xenobióticos (XBD) y de activación (AD), pero sin el dominio de unión a ADN (DBD). El inserto Pdr se clona junto al dominio de unión a ADN de Gal4 $\left(\mathrm{Gal}_{\mathrm{DBD}}\right)$, sustituyendo al propio. Además, se encuentra el promotor constitutivo $A D H 1$, y un epítopo cmyc que permite la detección de la proteína fusión por métodos inmunológicos. En la figura se muestra los sitios de corte de las enzimas de restricción empleadas (NcoI/EcoRI y BamHI).

En primer lugar, se obtuvieron los insertos con los factores de transcripción Pdr a partir de ADN genómico de la cepa de levadura BY4741 mediante PCR. Para la amplificación del inserto se emplearon cebadores que incorporaban en sus extremos 5' sitios de corte para las endonucleasas NcoI/EcoRI y BamHI. Cada reacción de amplificación se realizó por duplicado, con un volumen final de $100 \mu \mathrm{l}$, se añadió $1 \mu \mathrm{l}$ de cada uno de los cebadores (primers) a $10 \mathrm{pmol} / \mu \mathrm{l}, 10 \mu \mathrm{l}$ de dNTPs a $2 \mathrm{mM}, 1 \mu \mathrm{l}$ (10 ng) de ADN molde, $10 \mu \mathrm{l}$ de tampón de PCR 10x comercial (Thermo Scientific), $10 \mu \mathrm{lde} \mathrm{MgCl}_{2}$ a $25 \mathrm{mM}$ (Thermo Scientific), $1 \mu \mathrm{l}$ de enzima TrueStart Hot Start Taq DNA Polymerase a $1 \mathrm{U} / \mu 1$ (Thermo Scientific) y $66 \mu \mathrm{l}$ de $\mathrm{H}_{2} \mathrm{O}$. Las condiciones de amplificación fueron: un 
paso de desnaturalización, de 5 minutos a $94^{\circ} \mathrm{C} ; 35$ ciclos de amplificación (desnaturalización durante $30 \mathrm{seg}$ a $94^{\circ} \mathrm{C}$, alineamiento durante $30 \mathrm{seg}$ a $53^{\circ} \mathrm{C}, \mathrm{y}$ extensión durante $4 \min$ a $72^{\circ} \mathrm{C}$ ); y un paso final de elongación de $10 \mathrm{~min}$ a $72^{\circ} \mathrm{C}$. Se comprobó si la amplificación había sido correcta mediante un gel de agarosa al $1 \%$ y se purificó el amplicón con el kit QIAquick PCR Purification (Qiagen).

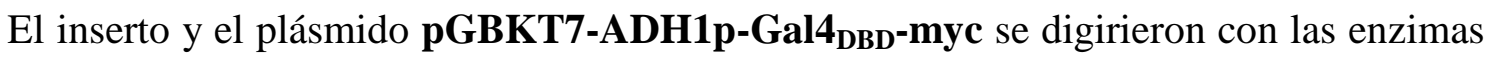
de restricción NcoI/EcoRI y BamHI toda la noche $(\mathrm{o} / \mathrm{n})$ a $37^{\circ} \mathrm{C}$. A continuación, se purificaron inserto y vector con QIAquick PCR Purification (Qiagen) y Geneclean ${ }^{\circledR}$ Turbo Kit (QBiogene, Inc), respectivamente. La ligación entre vector e inserto se realizó empleando Rapid DNA Ligation Kit (Thermo Scientific). El producto de ligación fue empleado en la transformación de bacterias DH5a competentes según el protocolo habitual. Las colonias obtenidas fueron cultivadas en tubos de precultivo con LB líquido suplementado con kanamicina, y se les extrajo y purificó el ADN plasmídico empleando el kit NucleoSpin Plasmid (Macherey Nagel). A continuación, se verificó la inserción mediante digestión con NcoI/EcoRI y BamHI, y por PCR empleando los cebadores correspondientesa los insertos. De nuevo, se visualizó con gel de electroforesis al $1 \%$.

La cepa de levadura $\Delta$ gal4 se transformó con ambos plásmidos (pAG413-GAL1 UAS- $_{\text {- }}$

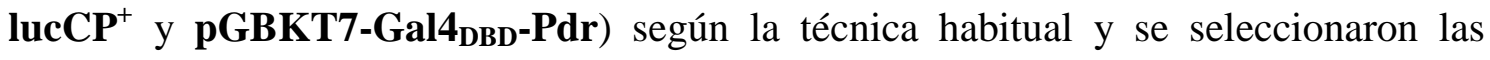
colonias positivas en medio sólido SD-his-trp.

\section{Oligonucleótidos.}

En la tabla suplementaria 6 se muestran los oligonucleótidos utilizados en este trabajo.

\section{Técnicas de manipulación de ADN.}

\subsection{Técnicas de transferencia génica.}

\subsubsection{Transformación de bacterias.}

La transformación se realizó a partir de alícuotas de un stock de células competentes de E. coli. A cada tubo, se añadieron aproximadamente 100 ng de DNA plasmídico, y se incubó durante 30 minutos en hielo. Se sometió a las células a un shock térmico durante 45 segundos a $42^{\circ} \mathrm{C}$, e, inmediatamente, se depositaron de nuevo en hielo durante 5 minutos. A continuación, se añadió $1 \mathrm{ml}$ de medio LB y se incubaron durante 1 hora a $37^{\circ} \mathrm{C}$. Los tubos fueron centrifugados (10000 rpm, $1 \mathrm{~min}$ ), el sobrenadante se desechó y 
las células se cultivaron en medio sólido selectivo (LB con ampicilina/kanamicina) a $37^{\circ} \mathrm{C}$ durante 1-2 días hasta la aparición de colonias de transformantes.

\subsubsection{Transformación de levaduras.}

La transformación de levadura se realizó mediante el método del acetato de litio (Gietz et al., 1995), descrito a continuación.

Se creció un cultivo líquido de levadura en $50 \mathrm{ml}$ YPD hasta una densidad óptica de 0,7-1,2 a $600 \mathrm{~nm}$, en el espectrofotómetro Eppendorf BioPhotometer Plus y se centrifugaron las células en un tubo Falcon de $50 \mathrm{ml}$ (3 min, 3000rpm). Se lavaron con agua estéril y con LiTE 1x estéril (0.1M acetato de litio en 1xTE (10mM Tris/HCl pH 7.6; 1mM EDTA)), y el pellet se resuspendió en $500 \mu \mathrm{l}$ de LiTE 1x. Se incubó las células durante 15 minutos a $30^{\circ} \mathrm{C}$ para hacerlas competentes y, a continuación, se añadieron 0,5-5 $\mu \mathrm{g}$ de $\mathrm{ADNa} 60 \mu \mathrm{l}$ de células competentes, y se añadió $5 \mu 1$ de una solución de ADN monocatenario de salmón al 0,1\% y $300 \mu$ de LiTE/40\% PEG4000 (9 volúmenes de PEG4000 45\% y 1 volúmen de LiTE 10x), y se mezcló bien con el vórtex. La mezcla se incubó durante 30 minutos a $30^{\circ} \mathrm{C}$, y después durante 20 minutos a $42^{\circ} \mathrm{C}$, para permitir la entrada del $\mathrm{ADN}$ en la célula. Finalmente, se centrifugó a 10000 rpm durante 1 minuto, se lavó con agua estéril y se resuspendió el pellet en el líquido remanente. Las células se sembraron en placas con medio selectivo. Las colonias de levadura transformadas aparecieron 2-3 días después de la incubación de las placas a $28^{\circ} \mathrm{C}$.

\subsection{Técnicas de extracción de ADN.}

Para la extracción de ADN genómico se empleó un protocolo de aislamiento rápido del ADN genómico. En primer lugar se creció un cultivo de levadura en $3 \mathrm{ml}$ de medio YPD líquido hasta saturación en agitación a $28^{\circ} \mathrm{C}$ durante toda la noche. Las células se precipitaron por centrifugación (10000 rpm, $1 \mathrm{~min}$ ) en un microtubo eppendorf de 1,5 $\mathrm{ml}$, y el pellet se lavó con agua MiliQ, se resuspendió en $200 \mu \mathrm{l}$ de tampón PP (100mM Tris/HCl pH 7.5, 10mM EDTA, $10 \mu 1 / \mathrm{ml} \beta$-mercaptoetanol, $0.2 \mathrm{mg} / \mathrm{ml}$ zymolyasa) y se incubó a $37^{\circ} \mathrm{C}$ durante $1 \mathrm{~h}$ para obtener los protoplastos de las células. A continuación se añadió $200 \mu \mathrm{l}$ de tampón de lisis $(0.2 \mathrm{M} \mathrm{NaOH}, 1 \%$ SDS $)$, mezclando por inversión, y se incubó a $65^{\circ} \mathrm{C}$ durante 20 minutos. Tras la lisis celular, se añadió $200 \mu$ de acetato potásico $5 \mathrm{M}$ pH 5.5 y se mezcló por inversión. Se centrifugó durante 3 minutos a máxima velocidad (13000 rpm) y se pasó el sobrenadante a nuevos tubos eppendorf a los que se añadió $600 \mu \mathrm{l}$ de isopropanol para precipitar el ADN cromosómico, y se 
centrifugó de nuevo (1 min, 13000rpm). Por último, se lavó el pellet con etanol (70\%), se secó bien y se resuspendió en $50 \mu 1$ de agua.

Para la extracción de ADN plasmídico se empleó el kit NucleoSpin Plasmid (Macherey-Nagel). De forma resumida, este protocolo consiste en lisar y eliminar los residuos celulares del cultivo bacteriano con el ADN plasmídico de interés, pasar este lisado por las columnas del kit para que el ADN sea adsorbido en su membrana, y tras ser lavado, eluírlo.

\subsection{Amplificación y purificación de fragmentos de ADN}

La amplificación de fragmentos de ADNespecíficos se realizó mediante la reacción en cadena de la polimerasa (PCR), con la enzima ADN polimerasa $(1 \mathrm{U} / \mu \mathrm{L})$ de Biotools o con la TrueStart Hot Start Taq DNA polimerase (Thermo Scientific) y adaptando las condiciones de amplificación a los cebadores utilizados y el tamaño del amplicón. La cuantificación del ADN obtenido se llevó a cabo con el aparato NanoDrop ${ }^{\circledR}$ ND-1000 Spectrophotometer (ThermoScientific), y su calidad y tamaño se comprobó en un gel de agarosa al 1\%. Para purificar los productos de PCR se utilizó el kit QIAquick PCR Purification (Qiagen), el cual utiliza columnas para adsorber el ADN y posteriormente, eluirlo. Para purificar fragmentos de ADN de geles, se utilizó el Geneclean® Turbo Kit (QBiogene, Inc), también basado en la purificación de ADN por columnas.

\subsection{Digestión con enzimas de restricción y electroforesis en gel de agarosa.}

El producto de $\mathrm{ADN}$ obtenido de extracciones y/o purificaciones fue digerido mediante enzimas de restricción para poder comprobar posteriormente en un gel de agarosa al 1\% si estos procesos habían sido satisfactorios.

Las reacciones de digestión contenían 2-5 $\mu$ l de ADN, $2 \mu 1$ de tampón de enzima (10x), 1-2 U de enzima (Fermentas) y agua MiliQ hasta un volumen final de $20 \mu$ l. Las reacciones de digestión se incubaron a la temperatura óptima de la enzima empleada, durante 1-2 horas, de forma general.

Los productos de digestión obtenidos, así como los productos de PCR fueron comprobados en un gel de agarosa al 1\% (0.5g agarosa, $50 \mathrm{ml}$ TAE1x, $1 \mu 1$ de bromuro de etidio (10 mg/ml)) con tampón 1xTAE (TAE 50x: 57,1 ml de ácido acético glacial, $100 \mathrm{ml}$ de 0,5M EDTA $\mathrm{pH} 8,0$, y agua destilada hasta $1 \mathrm{~L}$ ). Las muestras fueron mezcladas con Loading dye 6x (Thermo Scientific) para poder ver el avance en el gel, se inyectaron en éste, y se dejó correr a un voltaje de 90-100 V durante 
aproximadamente 1 hora. Junto con las muestras se inyectó un marcador de masas (Massruler) de Thermo Scientific con el que comparar las bandas obtenidas para conocer su masa aparente.

\section{Análisis de expresión de levadura: RT-PCR y microarray}

Se llevó a cabo un estudio a nivel transcriptómico en el mutante $\Delta p d r 5$ tratado con las micotoxinas citrinina (CIT) y ocratoxina A (OTA). Para ello se empleó la técnica de microarray y PCR de transcripción reversa (RT-PCR) como técnica de confirmación. Al trabajar con ARN se mantuvieron las muestras en hielo durante el experimento y se tuvo especial cuidado en el tratamiento del material utilizado para evitar la degradación y contaminación de las muestras.

\subsection{Toma de muestras.}

Se crecieron cultivos de levadura $\Delta p d r 5$, en matraces con medio $\mathrm{SD}$, hasta una $\mathrm{OD}_{600}=2$ y se sometieron a cuatro tratamientos distintos: control (no estrés), citrinina (200 ppm durante $60 \mathrm{~min}$ ), ocratoxina A (200 ppm durante $30 \mathrm{~min}$ ), y una combinación de ambas (100 ppm cada una durante $30 \mathrm{~min}$ ). Se tomaron 4 alícuotas de $10 \mathrm{ml}$ de los cultivos para cada uno de los tratamientos en los tiempos correspondientes. Cada una de estas alícuotas se centrifugaron (3 min, $3000 \mathrm{rpm}$ ) para precipitar las células, y posteriormente, se lavó el pellet con agua MilliQ fría. Se mantuvieron a $-20^{\circ} \mathrm{C}$ hasta obtener todas.

\subsection{Extracción de ARN con el método del "fenol ácido" $(\mathrm{pH}=4.3)$.}

Se resuspendieron las muestras en $400 \mu \mathrm{l}$ de tampón TES $(10 \mathrm{mM}$ Tris / $\mathrm{HCl} \mathrm{pH}=7.5$, 10mM EDTA, $0.5 \%$ SDS). A continuación se añadieron $400 \mu 1$ de fenol ácido y se mezcló bien con vórtex. Se incubaron las muestras a $65^{\circ} \mathrm{C}$ durante 45 minutos y se pusieron seguidamente en hielo 5 minutos. Para separar el ARN del fenol, se centrifugaron las muestras durante 1 minuto a $10000 \mathrm{rpm}$. La fase acuosa se transfirió a un nuevo tubo eppendorf y se volvió a añadir $400 \mu \mathrm{l}$ de fenol ácido, se mezcló y centrifugó (10000 rpm, 1 min). De nuevo, el sobrenadante se pasó a nuevos microtubos y se añadieron $40 \mu \mathrm{l}$ de acetato de sodio $3 \mathrm{M}$ con $\mathrm{pH}=5$ y 2.5 volúmenes de etanol. A continuación se centrifugaron las muestras a $14000 \mathrm{rpm}$ durante 10 minutos. Tras desechar el sobrenadante se lavó el pellet con etanol (70\%), centrifugando a $14000 \mathrm{rpm}$ durante 5 minutos. Tras ello, se secó bien el pellet y se resuspendió en $100 \mu$ de agua MilliQ. 
La cantidad de ARN presente en cada una de las muestras se cuantificó mediante el espectrofotómetro NanoDrop ${ }^{\circledR}$ ND-1000 Spectrophotometer (Thermo Scientific). Para comprobar la calidad del ARN extraído se analizaron las muestras mediante un gel de agarosa al 1\% en tampón 1 x MAE (10x MAE: 0.2 M MOPS pH=7, ajustando el pH con $\mathrm{NaOH}, 50 \mathrm{mM}$ Acetato de Sodio, $10 \mathrm{mM}$ EDTA) con formaldehido (2\%). El tampón de electroforesis se preparó con 100mL de tampón MAE 10x y $30 \mathrm{~mL}$ de formaldehído al 37\%, en un volumen final de 1L. Antes de cargarlas en el gel, se mezclaron $10 \mu \mathrm{L}$ de muestracon $40 \mu \mathrm{L}$ de tampón de carga $(2,2 \mathrm{~mL}$ deformamida, $0,8 \mathrm{~mL}$ de formaldehído, 0,5mL de tampón MAE 10x, 0,4mL de glicerol al 80\%, y 0,1mL de azul de bromofenol al $2 \%$ ) y $2 \mu \mathrm{L}$ de bromuro de etidio al $0,1 \%$. La mezcla se calentó a $56^{\circ} \mathrm{C}$ durante $10 \mathrm{~min}$ y se corrieron en elgel a $150 \mathrm{~V}$ durante $2-3$ horas, para poder comprobar la aparición de los rRNAs a 3,5 y 1,8 kb.

\subsection{Purificación del ARN total.}

Una vez determinada la calidad del ARN, se eliminó el ADN residual de la muestra con la enzima DNasaI (DNase I Amplification Grade $(1 \mathrm{U} / \mu \mathrm{L})$ de Invitrogen) y se empleó un inhibidor de ribonucleasas (RNase Out, Invitrogen) para evitar la degradación del ARN. Se incubó 30 min a $37^{\circ} \mathrm{C}$ una mezcla con $50 \mu \mathrm{g}$ de RNA total, $10 \mu \mathrm{L}$ de tampón 10x, $2 \mu \mathrm{L}$ de enzima DNasa I, $1 \mu \mathrm{L}$ de inhibidor de ribonucleasas y agua, hasta un volumen de $100 \mu \mathrm{L}$. Tras este tratamiento se empleó RNeasy Mini Kit (Qiagen) para purificar y concentrar el ARN. En resumen, se pasó la muestra por columnas del kit para retener el ARN en su membrana y posteriormente eluirlo purificado. De nuevo, se cuantificó el ARN total con el NanoDrop.

\subsection{Análisis mediante microarray.}

\subsubsection{Hibridación en cristales.}

El ARN purificado fue enviado al Servicio de Genómica del Instituto de Biología Molecular y Celular de Plantas (IBMCP (Valencia, España)) donde se realizó el resto del proceso experimental del análisis transcriptómico. Resumidamente, las muestras fueron marcadas con el fluoróforo Cianina-3 (Cy3), hibridadas en 4 cristales Yeast Gene Expression $8 * 15 K$ Microarray (Agilent), y escaneadas con el escáner Agilent DNA Microarray Scanner (G2505B). Los datos crudos se obtuvieron empleando Feature Extraction software 9.5.1. 


\subsubsection{Análisis bioinformático y estadístico.}

El análisis de los datos crudos se realizó empleando el programa GeneSpring 12.6 de Agilent. Los datos se normalizaron por el método de cuantiles y se analizaron estadísticamente con el t-Test de Student. Se seleccionaron las diferencias significativas en expresión génica empleando un p-value <0.05. Para evitar la detección de falsos positivos, se aplicó una corrección de test multiples (Bonferroni FWER) que permitió obtener p-values corregidos. Los grupos funcionales de genes significativos fueron identificados mediante la herramienta YeastMine Gene Ontology (GO) de la base de datos Saccharomyces cerevisiae Genome Database (SGD). Este experimento, con los datos obtenidos, se registró en Gene Expression Omnibus (GEO) Database con el número de acceso GSE84187.

\subsection{RT-PCR.}

Para comprobar el resultado del microarray se observó el nivel transcripcional del gen GRE2 mediante la técnica PCR de transcripción reversa (RT-PCR) a partir del ARN purificado previamente (ver apartado 6.3).

\subsubsection{Síntesis de ADNc por transcripción reversa.}

Se utilizó el kit Superscript III: cDNA first strand synthesis de Invitrogen. Las muestras se trataron por duplicado, por un lado en tubos denominados "RT" y que contenían la enzima retrotranscriptasa, y por otro, en tubos denominados "no RT", a los que no se les adicionó posteriormente la enzima y sirvieron de controles. Los tubos contenían $5 \mu \mathrm{l}$ de cada una de las muestras de RNA tratadas con DNasaI, $1 \mu 1$ de $50 \mu \mathrm{M}$ de cebador oligo $(\mathrm{dT})_{20}, 1 \mu \mathrm{l}$ de $10 \mathrm{mM}$ de mezcla de dNTPs y $3 \mu 1$ de agua MilliQ. Las mezclas de reacción obtenidas se incubaron a $65^{\circ} \mathrm{C}$ durante 5 minutos para desnaturalizar las hebras del ARN, y a continuación se pusieron en hielo al menos durante 1 minuto, para así permitir la unión de los cebadores a las colas poli-A del ARN mensajero. A cada una de las muestras se les adicionó en el siguiente orden: $2 \mu 1$ del tampón 10x de la Retrotranscriptasa, $4 \mu \mathrm{l}$ de $25 \mathrm{mM} \mathrm{MgCl}_{2}, 2 \mu 1$ de $0.1 \mathrm{M}$ DTT, $1 \mu 1$ de RNaseOut $40 \mathrm{U} / \mu \mathrm{l}$ y $1 \mu \mathrm{l}$ de la enzima SuperScriptIII $R T 200 \mathrm{U} / \mu \mathrm{l}$. Este último componente se sustituyó por agua en el caso de los controles "no RT". Se mezcló bien e incubamos a $50{ }^{\circ} \mathrm{C}$ durante 50 minutos e inmediatamente después se pusieron durante 5 minutos a $85{ }^{\circ} \mathrm{C}$ para detener la reacción y luego en hielo. Tras una rápida centrifugación, se les añadió $1 \mu \mathrm{l}$ de $\mathrm{RNasaH}$ y se incubaron durante 20 minutos a $37^{\circ} \mathrm{C}$. 
Una vez transcurridos los 20 minutos, se añadieron $90 \mu \mathrm{l}$ de agua MilliQ y se almacenaron las muestras a $-20^{\circ} \mathrm{C}$ hasta emplearlas en el análisis de RT-qPCR.

\subsubsection{Análisis mediante PCR cuantitativa a tiempo real (RT-qPCR).}

Una vez obtenido el ADNc se analizaron los niveles de expresión mediante RT-qPCR. El volumen de reacción fue $20 \mu 1$, por lo que cada una de ellas contenía $6 \mu 1$ de la mezcla a 3,3 $\mu \mathrm{M}$ de primers, $4 \mu \mathrm{l}$ de ADNc molde y $10 \mu \mathrm{l}$ de Master Mix (para 100 reacciones: $1000 \mu \mathrm{l}$ de Fast EvaGreen qPCR Master Mix (Biotium) y $12 \mu \mathrm{l}$ de 5(6)carboxy-X-rodamina (ROX, diluido a $0.1 \mu \mathrm{M}$ en DMSO). Estas reacciones de PCR cuantitativa, se llevaron a cabo mediante un detector de secuencias Applied Biosystem ${ }^{\mathrm{TM}} 7500$ Fast, siguiendo las condiciones que se muestran a continuación: desnaturalización inicial a $95{ }^{\circ} \mathrm{C}$ durante 2 minutos, a continuación 40 ciclos de 5 segundos a $95^{\circ} \mathrm{C}, 5$ segundos a $53^{\circ} \mathrm{C}$ y 30 segundos a $72^{\circ} \mathrm{C}$ (extensión).

A partir de las curvas de amplificación se compararon los $\mathrm{Ct}$ (Threshold Cycle) correspondientes a las distintas muestras para poder determinar la abundancia de ARN. Para ello, los valores de Ct obtenidos para cada uno de los genes, se compararon relativamente con respecto al gen $A C T 1$, gen de referencia empleado, puesto que no varía su expresión. El análisis de la expresión génica normalizada frente al gen de referencia se realizó mediante la siguiente fórmula: $2^{\mathrm{Ct}(\text { ACTI-GRE2) }}$.

\section{Técnicas de manipulación de proteínas.}

\subsection{Obtención de extractos proteicos totales.}

La obtención de extractos proteicos se realizó por dos métodos: hervido en tampón Laemmli y agitación con bolas. En ambos casos, las muestras y extractos se trataron con cuidado y en hielo durante todo el proceso, para evitar su degradación y contaminación.

\subsubsection{Obtención de extractos proteicos totales por hervido en tampón Laemmli.}

Para la obtención de extractos proteicos totales se empleó el método de hervido en tampón Laemmli. Se crecieron células de levadura en medio SD hasta una $\mathrm{OD}_{600}=0,8$ 1,2 y se tomaron alícuotas de $10 \mathrm{ml}$. A continuación, se centrifugaron 5 minutos a $3.000 \mathrm{rpm}$ y se lavaron con agua fría. La composición del tampón Laemmli 5X es de 0,3M de Tris/HCl $\mathrm{pH}$ 6,8, 7,5\% de SDS, 0,1M de DTT, 10mM de EDTA, 30\% de sacarosa y $0,25 \mathrm{mg} / \mathrm{ml}$ de azul de bromofenol. Seguidamente, se añadieron $150 \mu \mathrm{lde}$ tampón Laemmli 2X (a partir de stock Laemmli 5X: 0,3 M de Tris/ $\mathrm{HCl} \mathrm{pH}$ 6,8, 7,5\% de SDS, 0,1 M de DTT, $10 \mathrm{mM}$ de EDTA, 30\% de sacarosa y 0,25 mg/ml de azul de 
bromofenol) y se hirvió durante 5 minutos a $95^{\circ} \mathrm{C}$. Por último, el extracto obtenido fue almacenado a $-20^{\circ} \mathrm{C}$ hasta su uso.

\subsubsection{Obtención de extractos proteicos totales por agitación con bolas.}

En primer lugar, se crecieron cada una de las cepas en medio selectivo hasta una $\mathrm{OD}_{600}=1$. Se tomaron $10 \mathrm{ml}$ de cultivo y se sedimentaron las células por centrifugación (1500 rpm, $3 \mathrm{~min}, 4^{\circ} \mathrm{C}$ ). A continuación, se lavaron las células, primero con $1 \mathrm{ml} \mathrm{de}$ agua MQ fría y luego con $1 \mathrm{ml}$ de tampón de extracción A $(50 \mathrm{mM}$ Tris/ $\mathrm{HCl}$ pH=7,5; 15 mM EDTA; 2 mM DTT; 0,1\% Tritón X-100; 150 mM NaCl) frío. Tras el lavado, las células se resuspendieron en $1 \mathrm{ml}$ de tampón A con $1 \mathrm{mM}$ de PMSF y un inhibidor de proteasas (cOmplete ${ }^{\mathrm{TM}}$, Mini, EDTA-free Protease Inhibitor Cocktail (Roche), 1 tableta en $10 \mathrm{ml}$ ). Seguidamente, las células resuspendidas se transfirieron a microtubos de 2 $\mathrm{ml}$ y se añadieron aproximadamente $500 \mu \mathrm{l}$ de bolas de vidrio $(0,5 \mathrm{mM}$ Glass Beads, Biospec Products, Inc.). Se rompieron las células mediante agitación fuerte, empleando el equipo Precellys ${ }^{\circledR}$ Evolution (Bertin Technologies). Para ello, se realizaron dos ciclos de agitación durante 20 segundos a $7.500 \mathrm{rpm}$, con un descanso de 30 segundos entre éstos. Este protocolo se repitió 3 veces, dejando las muestras en hielo durante un minuto entre agitaciones. Tras la ruptura de las células, se centrifugaron a $4^{\circ} \mathrm{C}$ durante 5 minutos a $10.000 \mathrm{rpm}$. El sobrenadante se transfirió a nuevos tubos de 1,5 ml y se añadió $1 / 5$ vol de tampón de carga 5x Laemmli. Por último, se hirvieron las muestras a $95^{\circ} \mathrm{C}$ durante 5 minutos y se almacenaron a $-20^{\circ} \mathrm{C}$ hasta su uso.

\subsection{Electroforesis de proteínas.}

La electroforesis de proteínas se realizó empleando el sistema Mini Protean 3 (BioRad), en el que se utilizan geles de poliacrilamida al $10 \%$ en condiciones desnaturalizantes (SDS-PAGE), de forma que la movilidad de las proteínas depende sólo de su peso molecular. Los geles tienen dos capas: de empaquetamiento y de separación en función del tamaño. La capa de empaquetamiento se compone de $4 \%$ de acrilamida:bisacrilamida 40:0,8, 0,1\% de SDS, $125 \mathrm{mM}$ de Tris/HCl, $1 \%$ de APS y $0,1 \%$ de TEMED a $\mathrm{pH} 6,8$. La capa de separación se compone de $12 \%$ de acrilamida:bisacrilamida 40:0,8, 0,1\% de SDS, $375 \mathrm{mM}$ de Tris/HCl, $1 \%$ de APS y 0,1\% de TEMED a pH 8,8. La electroforesis se llevó a cabo a voltaje constante de 70$80 \mathrm{~V}$ y con el tampón de resolución SDS-PAGE $1 \mathrm{X}(0,19 \mathrm{M}$ de glicina y $0,1 \%$ de SDS ajustado a $\mathrm{pH}$ 8,3 con Tris). Las muestras se inyectaron en el gel junto al marcador de pesos moleculares PageRuler ${ }^{\mathrm{TM}}$ Prestained Protein Ladder (Fermentas). 


\subsection{Transferencia a membrana de proteínas (Western Blot).}

Tras separar las proteínas en el gel, fueron transferidas a membranas para que mejoraran su accesibilidad en las reacciones de detección mediante anticuerpos. Se emplearon las membranas de Immunoblot ${ }^{\circledR}$ PVDF 0,45 $\mu \mathrm{m}$ (Amersham ${ }^{\mathrm{TM}}$ Hybond $^{\mathrm{TM}}$, GE Healthcare) y se utilizó el sistema Mini-Trans Blot (BioRad) para transferir las proteínas mediante corriente eléctrica. El tampón de transferencia utilizado estaba compuesto por SDSPAGE 1X y metanol al $20 \%$ para permitir la ruptura del complejo SDS-proteína y facilitar su unión a la membrana. La transferencia se realizó a $10 \mathrm{~V}$ y a $4^{\circ} \mathrm{C}$ durante toda la noche.

A continuación, se realizó la tinción de las membranas con DirectBlue 71 (DB71) al 0,008\% para comprobar la eficiencia de la transferencia y como control de carga. Las membranas de PVDF se sumergieron en la solución de tinción durante 5 minutos con agitación y el exceso de colorante se eliminó mediante la solución de lavado (40\% de etanol absoluto y $10 \%$ de ácido acético glacial). Por último, se escaneó la membrana y se eliminó la tinción con la solución de desteñido (50\% de etanol absoluto y $1 \mathrm{M}$ de bicarbonato sódico) durante 10-15 minutos.

\subsection{Detección inmunológica de proteínas.}

En primer lugar, se bloquearon los sitios de unión no específicos lavando la membrana en solución de bloqueo, compuesta por leche en polvo al 2\% en TBS 1X (TBS 10X: $1,5 \mathrm{M}$ de $\mathrm{NaCl}$ y $0,2 \mathrm{M}$ de Tris/ $\mathrm{HCl}$ a $\mathrm{pH} 7,6$ ) en agitación durante 30 minutos. A continuación, se incubó la membrana en solución de bloqueo con el anticuerpo primario específico, el anticuerpo monoclonal de ratón $\alpha$-myc (Roche), en una dilución 1:5000, durante 1 hora en agitación. Tras esta incubación se lavó la membrana 3 veces durante 10 minutos con tampón TBS 1X para eliminar el exceso de anticuerpo primario. Posteriormente, se incubó en TBS 1X con el anticuerpo secundario ( $\alpha$-HRP-ratón) en dilución 1:10000 durante 1 hora en agitación. Finalmente, se realizaron 3 lavados de 10 minutos con TBS $1 \mathrm{X}$.

La detección se realizó mediante el sistema $E C L^{T M}$ Prime Western Blotting Detection System (GE Healthcare - Amersham Biosciences). Este sistema permite, gracias a la existencia de peroxidasa en el segundo anticuerpo utilizado, detectar las proteínas de interés. La señal de quimioluminiscencia se obtuvo de forma electrónica mediante la cámara LAS-3000 (Fujifilm). 


\section{Sistema luciferasa.}

El sistema luciferasa (Rienzo et al., 2012) es un sistema reportero basado en la cuantificación, en tiempo real, de la expresión de luciferasa en células vivas de levadura, al someterlas a un estrés. La estructura de este sistema se muestra en la Figura 12.

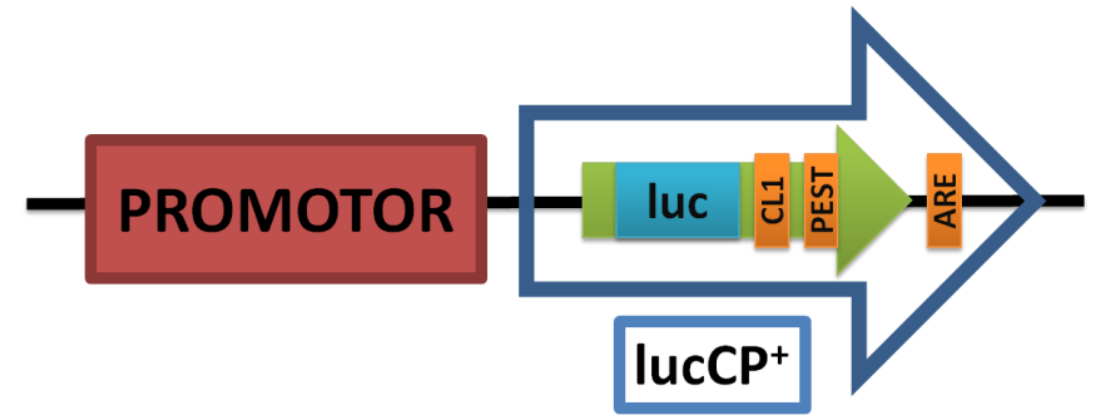

Figura 12. Esquema del sistema luciferasa. El sistema luciferasa contiene la secuencia de un promotor de interés fusionado al gen de luciferasa desestabilizada $\left(\operatorname{lucCP}{ }^{+}\right)$. El gen lucCP${ }^{+}$contiene, junto al gen de luciferasa de luciérnaga, dos motivos de degradación proteica (hCL1 y hPEST) y de ARNm (ARE), de forma que no hay acumulación y se detecta la expresión de la luciferasa a medida que ésta va sucediendo.

En esta tesis, se emplearon variantes del sistema reportero de luciferasa desestabilizada descrito previamente en Rienzo et al., 2012. Las construcciones empleadas se describen en el apartado 3.

En primer lugar, las cepas de levadura fueron crecidas en medio mínimo SD suplementado con aminoácidos, en función de su auxotrofía, durante toda la noche, hasta una $\mathrm{OD}_{600} \sim 2$. A continuación, se incubaron los cultivos con luciferina (Synchem) a $0,5 \mathrm{mM}$ (a partir de stock $10 \mathrm{mM}$ ) durante $60 \mathrm{~min}$ a $28^{\circ} \mathrm{C}$ en agitación, y se cargaron alícuotas de $120 \mu \mathrm{l}$ de cultivo por pocillo, en una placa de 96 pocillos (Nunc). Estos pocillos se cargaron con un rango de concentraciones del estrés a estudiar. Cada concentración de estrés y cepa cargada en la placa se hizo por triplicado. Inmediatamente después de cargar la placa, se puso en el luminómetro GloMax Multidetection System (Promega). Para el análisis de los resultados se normalizaron los datos por su OD correspondiente y se procesaron empleando Microsoft Excel.

\section{Ensayos de sensibilidad: crecimiento en medio sólido (Goteo).}

Se realizó una caracterización fenotípica de distintas cepas de levadura ante diversas drogas mediante crecimiento en medio sólido (goteo o droptest). Se crecieron los cultivos de levadura durante la noche hasta $\mathrm{OD}_{600}=1$ en medio mínimo $\mathrm{SD}$ a $28^{\circ} \mathrm{C}$ en agitación. A continuación, en una placa multipocillo estéril, se realizaron tres diluciones seriadas $(1: 10,1: 100,1: 1000)$ de los cultivos y se les sometió a determinadas condiciones de estrés. Una vez preparada la placa se utilizó un aplicador manual 
(Sigma) para poder depositar las gotas correctamente sobre el medio sólido a distintos tiempos, y se incubaron las placas a $28^{\circ} \mathrm{C}$ durante 2-3 días. 

RESULTADOS 



\section{CAPÍTULO 1: MECANISMOS DE TOXICIDAD DE CITRININA (CIT) Y OCRATOXINA A (OTA).}

Las micotoxinas citrinina (CIT) y ocratoxina A (OTA) son dos importantes contaminantes en alimentos, considerados tóxicos para el ser humano. Estos compuestos suelen aparecer juntos en muchas ocasiones, por lo que se ha sugerido que puedan tener un efecto sinérgico en su toxicidad. La mayoría de estudios sugieren que esta toxicidad proviene del estrés oxidativo producido por estas micotoxinas.

En estudios preliminares realizados en el modelo de levadura Saccharomyces cerevisiae por nuestro laboratorio (Pascual-Ahuir et al., 2014) se observó la activación de los promotores de respuesta a estrés GRE2 y SOD2, así como indicios de la posible implicación de ciertos genes de repuesta a estrés oxidativo y de resistencia multidroga, en células sometidas a la micotoxina citrinina.

En este trabajo se quiso conocer mejor los posibles mecanismos de toxicidad de citrinina y ocratoxina A, así como la posible relación entre estas dos micotoxinas. Para ello, se realizaron varias aproximaciones: análisis a nivel transcriptómico con microarray, de expresión génica a través de reporteros luciferasa, y ensayos de sensibilidad en placa.

\section{Perfiles de expresión génica de los promotores GRE2 y SOD2 ante CIT y OTA.}

\subsection{Respuesta dosis-dependiente de la cepa wild type.}

En primer lugar, se estudiaron los perfiles dosis-respuesta de los promotores inducibles a estrés general (GRE2) y a estrés oxidativo (SOD2) ante distintas condiciones de citrinina y ocratoxina A. Para ello, empleamos la cepa silvestre BY4741 con plásmidos de fusión del gen de luciferasa desestabilizada a los promotores GRE2 (GRE2-lucCP ${ }^{+}$) (Rienzo et al., 2012) y SOD2 (SOD2-lucCP ${ }^{+}$) (Dolz-Edo et al., 2013). Los valores obtenidos tras su cuantificación en luminómetro representan la expresión luciferasa cuantificada por su actividad y medida como unidades de luz relativas, y fueron normalizados por la OD correspondiente. El resultado se muestra en la Figura 13. 

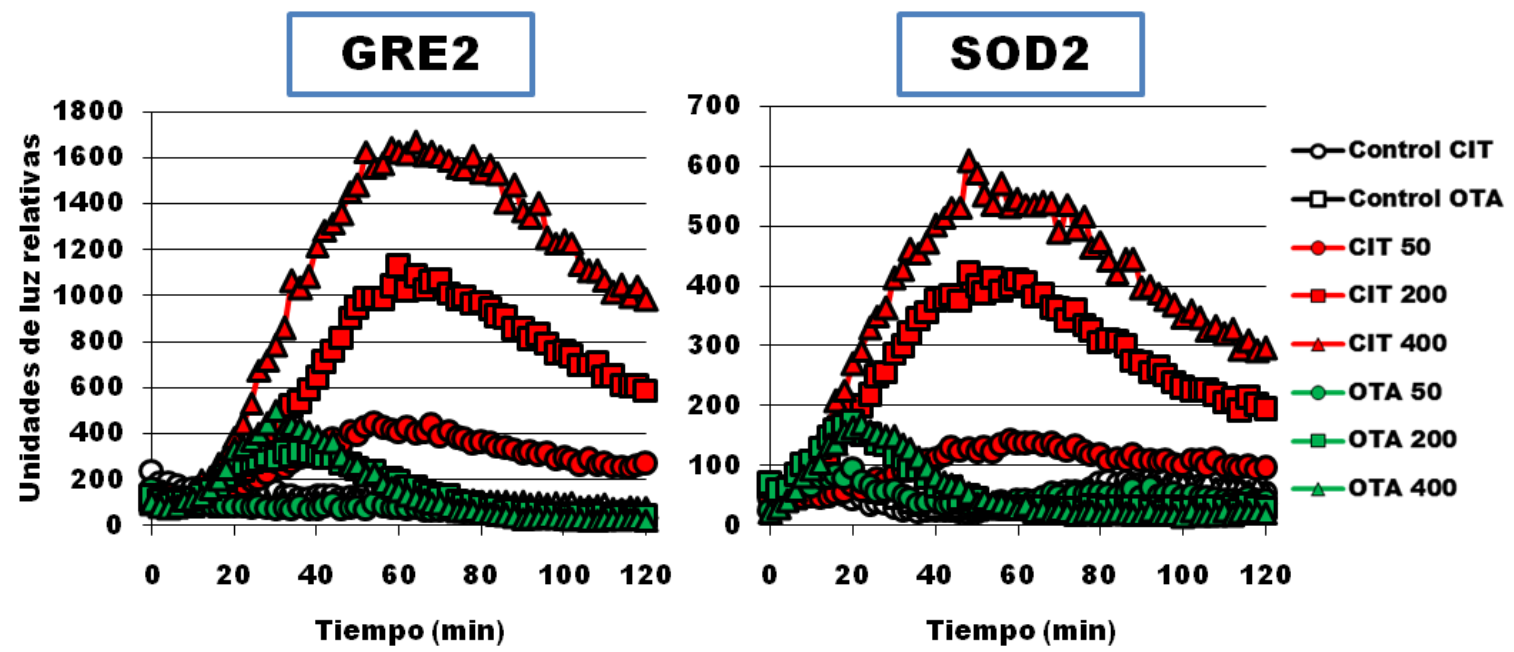

Figura 13. Perfiles dosis-respuesta de la expresión luciferasa de los promotores $\boldsymbol{G R E 2}$ y $\boldsymbol{S O D 2}$. Las células de la cepa BY4741 con las construcciones GRE2-lucCP ${ }^{+}$y SOD2-lucCP ${ }^{+}$se sometieron a un rango de concentraciones $(0$, 50, 200 y 400 ppm) de citrinina y ocratoxina A, y se cuantificó la actividad luciferasa con luminómetro por triplicado. Desviación estándar del ensayo no supera el $15 \%$.

En la Figura 13 se observan resultados similares para ambos promotores. Los perfiles dosis-respuesta muestran una activación transitoria con un aumento progresivo de actividad luciferasa conforme aumenta la concentración de micotoxina. En el caso del tratamiento con OTA parece haber saturación en la actividad luciferasa alrededor de 200 ppm, mientras que en el tratamiento con CIT la inducción observada alcanza los 400 ppm. Además, tanto GRE2 como SOD2 presentan niveles de expresión superiores ante CIT que ante OTA, y por otra parte, se observa mayor rapidez en alcanzar los picos de actividad máxima en OTA (aproximadamente $30 \mathrm{~min}$ ) que en CIT (aproximadamente $60 \mathrm{~min}$ ). Esto podría indicar que la inducción de estos genes y su participación en la respuesta a OTA es más transitoria y menos importante que en respuesta a CIT.

\subsection{Comparación de wild type y mutante $\Delta p d r 5$.}

Una vez caracterizado el perfil dosis-respuesta a citrinina y ocratoxina A en la cepa silvestre, se estudió la respuesta a estas micotoxinas en el mutante $\Delta p d r 5$. Pdr5 está considerado como uno de los transportadores de membrana multidroga más importantes en Saccharomyces cerevisiae, y en estudios anteriores (Pascual-Ahuir et al., 2014) se comprobó que estaba implicado en la respuesta de defensa ante CIT. Por ello, quisimos analizar el efecto de estas toxinas en una cepa con dificultades en el transporte multidroga y así, poder comparar las posibles diferencias en los perfiles de ambos promotores.

En la Figura 14 se observan los resultados obtenidos en la comparación entre la cepa silvestre y el mutante $\Delta p d r 5$. En estos resultados se muestran mayores niveles de inducción en la cepa defectuosa en la función de Pdr5 en ambos promotores. Esto podría implicar problemas en la eliminación de CIT y OTA de la célula al no tener este transportador de membrana, de forma que estas toxinas se acumularían en el interior de ésta durante más tiempo. Estos resultados parecen indicar que Pdr5 tiene un papel 
importante en la respuesta de adaptación a estas micotoxinas, como ya se había indicado anteriormente.

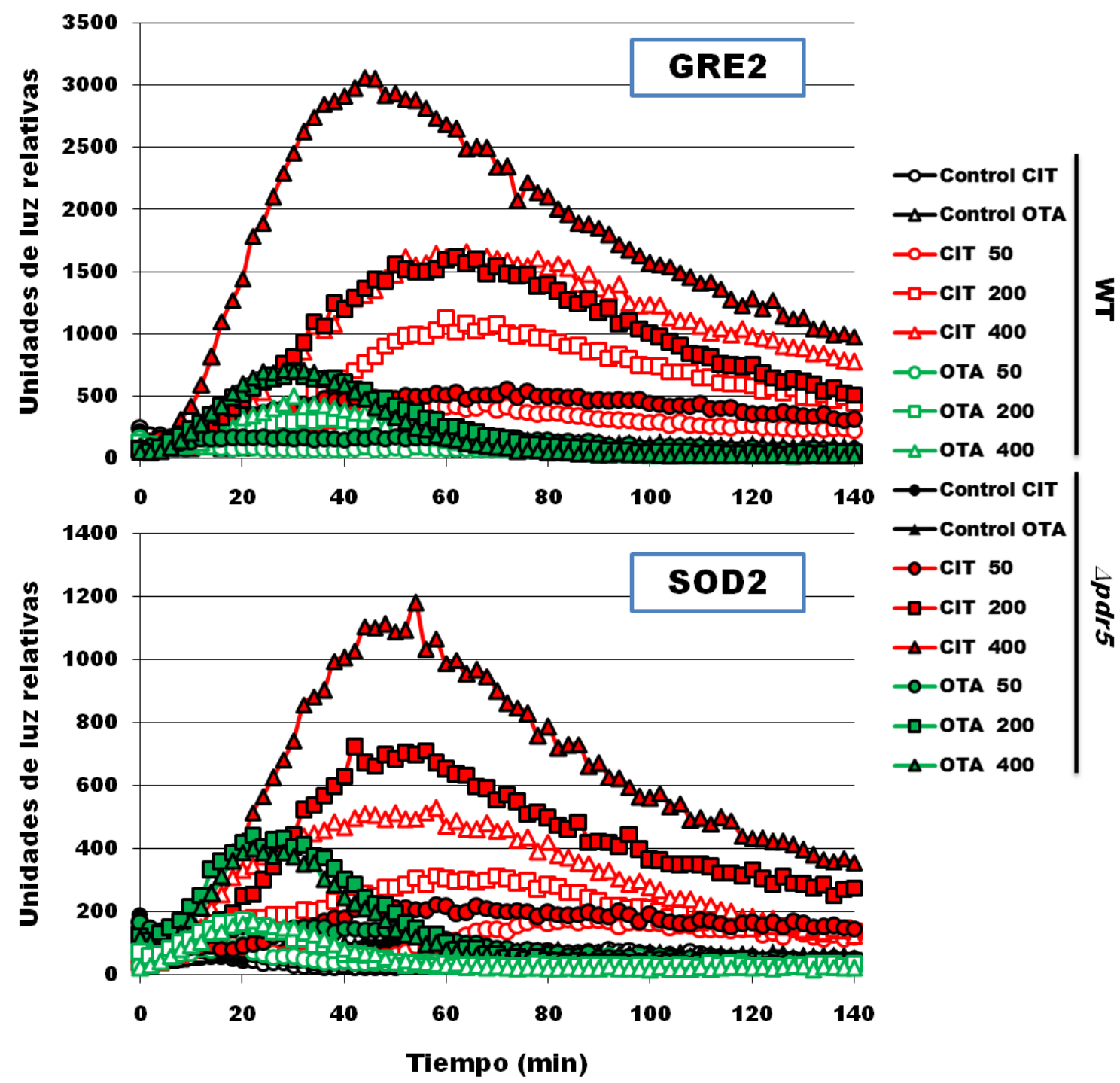

Figura 14. Comparación de perfiles dosis-respuesta de la expresión luciferasa de los promotores GRE2 y SOD2 de wild type y $4 p d r 5$. Las células de las cepas BY4741 y $\Delta p d r 5$ con las construcciones GRE2-lucCP ${ }^{+}$y $\mathrm{SOD}_{2}-\mathrm{lucCP}^{+}$se sometieron a un rango de concentraciones $(0,50,200$ y $400 \mathrm{ppm})$ de citrinina y ocratoxina $\mathrm{A}$, y se cuantificó la actividad luciferasa con luminómetro por triplicado. Desviación estándar del ensayo no supera el $15 \%$.

1.3. Respuesta de reporteros luciferasa GRE2-lucCP ${ }^{+}$y $\mathrm{SOD}_{2}-\mathrm{lucCP}{ }^{+}$frente a la combinación de citrinina y ocratoxina A.

Estudios anteriores (Klaric et al., 2013; Follmann et al., 2014) han sugerido que CIT y OTA, al aparecer juntas pudieran tener un efecto sinérgico en su toxicidad. Por ello, para terminar con el estudio de los reporteros $\mathrm{GRE}^{-}-\mathrm{lucCP}^{+}$y SOD2-lucCP ${ }^{+}$, quisimos estudiar, sobre estas mismas cepas, el posible efecto sinérgico de citrinina y ocratoxina A al combinar ambas micotoxinas en distintas concentraciones. En la Figura 15 se muestran los resultados obtenidos. 

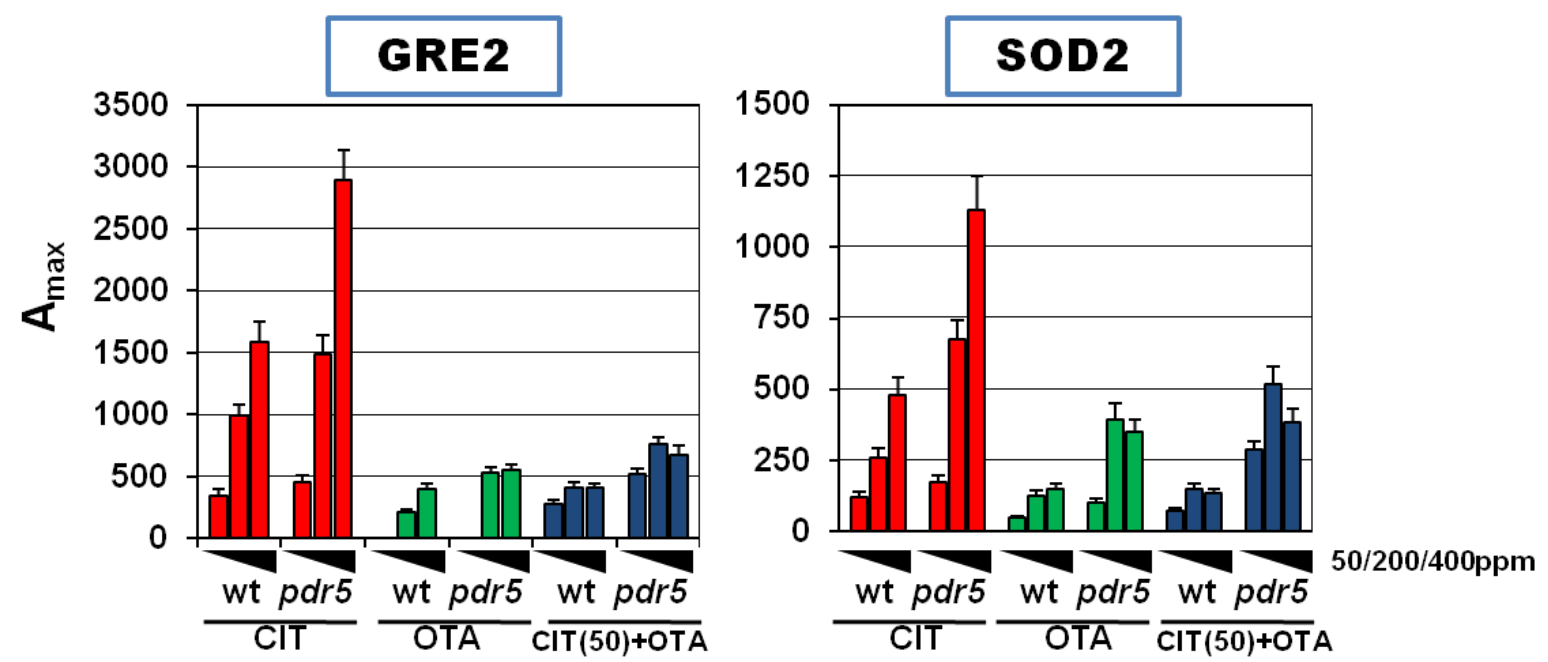

Figura 15. Efecto sinérgico de citrinina y ocratoxina A. Las células de las cepas BY4741 y $\Delta p d r 5$ con las construcciones GRE2-lucCP ${ }^{+}$y SOD2-lucCP ${ }^{+}$se sometieron a un rango de concentraciones $(0,50,200$ y 400 ppm) de citrinina y ocratoxina A por separado y combinadas (50 ppm citrinina con 50/200/400 ppm de ocratoxina A), y se cuantificó la actividad luciferasa con luminómetro por triplicado. En la figura se representan los puntos de actividad máxima para cada uno de los tratamientos con micotoxinas. Desviación estándar del ensayo no supera el 15\%.

La Figura 15 muestra nuevamente una mayor inducción de ambos promotores en el mutante $\Delta p d r 5$, así como las diferencias entre CIT y OTA. Como en los anteriores ensayos, la actividad luciferasa en el tratamiento con citrinina alcanza valores más elevados que en el tratamiento con ocratoxina A. Por su parte, los tratamientos combinados de micotoxina, al contrario de lo esperado, no mostraron un efecto sinérgico entre ambas, ya que se observa una inducción de los promotores menor que en los tratamientos sólo con citrinina.

Estos primeros resultados parecen indicar que citrinina y ocratoxina A tienen distintos efectos sobre los promotores inducibles por estrés GRE2 y SOD2, tanto en la cepa silvestre como en el mutante de deleción $\Delta p d r 5$. Además, Pdr5 parece tener un papel importante en la detoxificación de estas micotoxinas, ya que las células defectuosas en la síntesis de este transportador tienen niveles de inducción de los promotores de respuesta mayores, probablemente debido a un mayor efecto de estas drogas al no poder ser eliminadas de la célula eficientemente.

A continuación, para poder estudiar en mayor profundidad las diferencias observadas entre citrinina y ocratoxina A realizamos un análisis a nivel transcriptómico.

\section{Estudio transcriptómico del mutante $4 p d r 5$ sometido a distintas condiciones de citrinina y ocratoxina A.}

\subsection{Análisis de expresión genómica mediante microarray.}

Tras estudiar la respuesta de los promotores GRE2 y SOD2 con los reporteros luciferasa al someter las células a distintas condiciones de citrinina y ocratoxina A se observaron diferencias entre ambas drogas. Para conocer en más profundidad las diferencias de expresión en respuesta a estas micotoxinas se realizó un experimento a nivel 
transcriptómico en el mutante $\Delta p d r 5$ bajo cuatro tratamientos distintos: un control sin micotoxina, 200 ppm de CIT, 200 ppm de OTA, y una combinación de ambas (100 ppm de cada una). Tanto la selección de la cepa como de la concentración de micotoxina para cada tratamiento fue escogida tras los resultados de los experimentos con los reporteros luciferasa para tratar de optimizar los resultados del experimento con microarray.

Los resultados obtenidos se exponen a continuación, mostrando los genes sobreexpresados con un valor de corte 5 veces mayor al comparar las células tratadas con las no tratadas $(\mathrm{FC}>5)$. Las listas resultantes se muestran en la Tabla 1 para CIT, la Tabla 2 para OTA, y la Tabla 3 para el tratamiento combinado (CIT/OTA).

Tabla 1. Genes sobreexpresados con $\mathrm{FC}>5$ en tratamiento con 200ppm de CIT.

\begin{tabular}{|c|c|c|c|c|}
\hline Gen & $\begin{array}{l}\text { Nomenclatura } \\
\text { Standard }\end{array}$ & FC & p-value & Descripción \\
\hline YPL171C & OYE3 & 473.09 & $3.00 \times 10^{-08}$ & $\begin{array}{l}\text { NADPH oxidoreductasa con flavina } \\
\text { mononucleótido (FMN) }\end{array}$ \\
\hline YFL056C & AAD6 & 252.36 & $9.60 \times 10^{-07}$ & Aryl-alcohol deshidrogenasa putativa \\
\hline YDL243C & AAD4 & 252.12 & $1.77 \times 10^{-09}$ & Aryl-alcohol deshidrogenasa putativa \\
\hline YCL026C-A & FRM2 & 177.22 & $1.77 \times 10^{-05}$ & Nitroreductasa tipo II \\
\hline YLL060C & GTT2 & 142.38 & $4.50 \times 10^{-05}$ & Glutatión S-transferasa \\
\hline YBR008C & FLR1 & 120.60 & $1.83 \times 10^{-07}$ & $\begin{array}{c}\text { Transportador multidroga de membrana } \\
\text { plasmática de la Major Facilitator } \\
\text { Superfamily(MFS) }\end{array}$ \\
\hline YCL026C-B & HBN1 & 61.69 & $1.81 \times 10^{-06}$ & Proteína de función desconocida \\
\hline YGR213C & RTA1 & 57.84 & $1.77 \times 10^{-08}$ & $\begin{array}{l}\text { Proteína involucrada en resistencia a 7- } \\
\text { aminocolesterol }\end{array}$ \\
\hline YML116W & ATR1 & 54.76 & $1.45 \times 10^{-07}$ & $\begin{array}{l}\text { Bomba de eflujo multidroga de la Major } \\
\text { Facilitator Superfamily (MFS) }\end{array}$ \\
\hline YKR076W & ECM4 & 51.60 & $6.10 \times 10^{-06}$ & Glutatión transferasa clase omega \\
\hline YML131W & & 41.24 & $9.44 \times 10^{-03}$ & Proteína de función desconocida \\
\hline YHR139C & SPS100 & 35.16 & $4.78 \times 10^{-07}$ & $\begin{array}{l}\text { Proteína requerida en maduración de } \\
\text { pared de espora }\end{array}$ \\
\hline YFL057C & AAD16 & 33.52 & $2.12 \times 10^{-02}$ & Aryl-alcohol deshidrogenasa putativa \\
\hline YDR011W & SNQ2 & 31.05 & $6.78 \times 10^{-07}$ & $\begin{array}{l}\text { Transportador de membrana plasmática } \\
\text { ATP-binding cassette ( } \mathrm{ABC})\end{array}$ \\
\hline YOL151W & GRE2 & 25.82 & $2.28 \times 10^{-06}$ & $\begin{array}{l}\text { Reductasa 3-metilbutanal y } \\
\text { reductasametilglioxal NADPH-dependiente }\end{array}$ \\
\hline YKL086W & SRX1 & 25.63 & $5.22 \times 10^{-07}$ & Sulfiredoxina \\
\hline YDR406W & PDR15 & 18.06 & $1.12 \times 10^{-06}$ & $\begin{array}{l}\text { Transportador de membrana plasmática } \\
\text { ATP-binding cassette ( } \mathrm{ABC})\end{array}$ \\
\hline YLR108C & & 16.55 & $5.77 \times 10^{-08}$ & Proteína de función desconocida \\
\hline YDL020C & RPN4 & 15.80 & $9.41 \times 10^{-08}$ & $\begin{array}{l}\text { Factor de transcripción estimulador de } \\
\text { expresión de genes de proteosoma }\end{array}$ \\
\hline YNL117W & MLS1 & 15.05 & $3.95 \times 10^{-06}$ & Malato sintasa \\
\hline YOR328W & PDR10 & 14.52 & $2.41 \times 10^{-08}$ & $\begin{array}{l}\text { Transportador de membrana plasmática } \\
\text { ATP-binding cassette ( } \mathrm{ABC})\end{array}$ \\
\hline YHR199C & AIM46 & 13.34 & $1.58 \times 10^{-07}$ & Proteína de función desconocida \\
\hline YHR029C & YHI9 & 12.93 & $3.86 \times 10^{-07}$ & Proteína de función desconocida \\
\hline YGR256W & GND2 & 10.88 & $5.58 \times 10^{-07}$ & 6-fosfogluconato deshidrogenasa \\
\hline
\end{tabular}




\begin{tabular}{|c|c|c|c|c|}
\hline YBR244W & GPX2 & 10.49 & $3.56 \times 10^{-06}$ & $\begin{array}{l}\text { Fosfolípido hidroperóxido glutatión } \\
\text { peroxidasa }\end{array}$ \\
\hline YFL030W & AGX1 & 10.29 & $4.28 \times 10^{-08}$ & Alanina:glioxylato aminotransferasa (AGT) \\
\hline YDR453C & TSA2 & 9.61 & $2.01 \times 10^{-07}$ & $\begin{array}{c}\text { Tioredoxín peroxidasa citoplasmática } \\
\text { estrés-inducible }\end{array}$ \\
\hline YER143W & DDI1 & 9.54 & $8.66 \times 10^{-05}$ & $\begin{array}{l}\text { Proteína de unión v-SNARE inducible por } \\
\text { daño a AND }\end{array}$ \\
\hline YNR074C & AlF1 & 9.15 & $4.46 \times 10^{-07}$ & Efector mitocondrial de muerte celular \\
\hline YER042W & MXR1 & 9.01 & $2.11 \times 10^{-06}$ & Metionina-S-sulfóxido reductasa \\
\hline YJL101C & GSH1 & 8.93 & $1.30 \times 10^{-07}$ & Gamma glutamilcisteína sintetasa \\
\hline YHR138C & & 8.80 & $1.42 \times 10^{-03}$ & Proteína de función desconocida \\
\hline YHL036W & MUP3 & 8.61 & $1.13 \times 10^{-05}$ & Permeasa de baja afinidad a metionina \\
\hline YNL129W & NRK1 & 8.45 & $1.61 \times 10^{-05}$ & Nicotinamida ribósido quinasa \\
\hline YPR200C & ARR2 & 8.09 & $1.57 \times 10^{-04}$ & Arsenato reductasa \\
\hline YER103W & SSA4 & 7.80 & $2.65 \times 10^{-05}$ & $\begin{array}{l}\text { Proteína de choque térmico de la familia } \\
\qquad \text { HSP70 }\end{array}$ \\
\hline YJL045W & & 7.67 & $3.32 \times 10^{-07}$ & Isozima succinato deshidrogenasa \\
\hline YPL027W & SMA1 & 7.65 & $9.86 \times 10^{-07}$ & $\begin{array}{l}\text { Proteína involucrada en ensamblaje de } \\
\text { membrana de proespora }\end{array}$ \\
\hline YGR010W & NMA2 & 7.54 & $1.02 \times 10^{-07}$ & $\begin{array}{c}\text { Ácido nicotínico mononucleótido adenilil } \\
\text { transferasa }\end{array}$ \\
\hline YMR169C & ALD3 & 7.38 & $6.10 \times 10^{-04}$ & Aldehido deshidrogenasa citoplasmática \\
\hline YDR132C & & 7.33 & $1.74 \times 10^{-06}$ & Proteína de función desconocida \\
\hline YOR162C & YRR1 & 7.23 & $1.24 \times 10^{-07}$ & Factor de transcripción \\
\hline YMR038C & CCS1 & 6.93 & $6.96 \times 10^{-05}$ & Chaperona de cobre para Sod1p \\
\hline YJL219W & HXT9 & 6.93 & $1.67 \times 10^{-07}$ & Transportador de hexosa putativo \\
\hline YER142C & MAG1 & 6.82 & $5.46 \times 10^{-07}$ & 3-metil-adenina DNA glicosilasa \\
\hline YBR046C & ZTA1 & 6.71 & $1.13 \times 10^{-05}$ & Quinona reductasa NADPH-dependiente \\
\hline YNL231C & PDR16 & 6.61 & $7.41 \times 10^{-03}$ & $\begin{array}{l}\text { Proteína de transferencia de } \\
\text { Fosfatidilinositol (PITP) }\end{array}$ \\
\hline YPL091W & GLR1 & 6.49 & $1.49 \times 10^{-05}$ & $\begin{array}{c}\text { Glutatión oxidoreductasa citosólica y } \\
\text { mitocondrial }\end{array}$ \\
\hline YGR281W & YOR1 & 6.42 & $2.16 \times 10^{-03}$ & $\begin{array}{l}\text { Transportador de membrana plasmática } \\
\qquad \text { ATP-binding cassette }(\mathrm{ABC})\end{array}$ \\
\hline YGR197C & SNG1 & 6.29 & $3.47 \times 10^{-07}$ & $\begin{array}{c}\text { Proteína implicada en resistencia a } \\
\text { nitrosoguanidina y 6-azauracil }\end{array}$ \\
\hline YNL155W & CUZ1 & 6.15 & $5.38 \times 10^{-03}$ & $\begin{array}{l}\text { Proteína con papel en ruta ubiquitina- } \\
\text { proteosoma }\end{array}$ \\
\hline YAL054C & ACS1 & 6.12 & $3.74 \times 10^{-07}$ & Acetil-coA sintetasa \\
\hline YOL119C & $\mathrm{MCH} 4$ & 6.09 & $1.27 \times 10^{-05}$ & $\begin{array}{l}\text { Proteína similar a monocarboxilato } \\
\text { permeasas de mamífero }\end{array}$ \\
\hline YDL168W & SFA1 & 6.05 & $1.21 \times 10^{-05}$ & Alcohol y formaldehido deshidrogenasa \\
\hline YCR021C & HSP30 & 5.99 & $5.37 \times 10^{-03}$ & Regulador negativo de $\mathrm{H}^{+}$-ATPasa Pma1p \\
\hline YBR256C & RIB5 & 5.93 & $1.15 \times 10^{-03}$ & Riboflavin sintasa \\
\hline YOR052C & TMC1 & 5.85 & $9.56 \times 10^{-03}$ & $\begin{array}{l}\text { Proteína de dedo de zinc de tipo AN1 } \\
\text { de función desconocida }\end{array}$ \\
\hline YOL155C & HPF1 & 5.82 & $6.09 \times 10^{-05}$ & $\begin{array}{l}\text { Manoproteína de reducción de turbidez } \\
\text { (Haze-protective factor) }\end{array}$ \\
\hline YMR318C & $\mathrm{ADH} 6$ & 5.78 & $7.64 \times 10^{-03}$ & $\begin{array}{l}\text { Alcohol deshidrogenasa de cadena media } \\
\text { dependiente de NADPH }\end{array}$ \\
\hline YJL082W & IML2 & 5.77 & $4.56 \times 10^{-04}$ & Proteína de función desconocida \\
\hline YKL051W & SFK1 & 5.63 & $6.62 \times 10^{-06}$ & Proteína de membrana plasmática para \\
\hline
\end{tabular}




\begin{tabular}{|c|c|c|c|c|}
\hline & & & & normalizar niveles de PI4P \\
\hline YER185W & PUG1 & 5.62 & $3.14 \times 10^{-05}$ & $\begin{array}{c}\text { Proteína de membrana plasmática } \\
\text { implicada en transporte de protoporfirina y } \\
\text { hemo }\end{array}$ \\
\hline YIR017C & MET28 & 5.61 & $3.48 \times 10^{-06}$ & $\begin{array}{c}\text { Activador transcripcional basic leucine } \\
\text { zipper (bZIP) en complejo Cbf1p-Met4p- } \\
\text { Met28p }\end{array}$ \\
\hline YHL024W & RIM4 & 5.53 & $4.66 \times 10^{-06}$ & Proteína de unión a ARN putativa \\
\hline YGR243W & MPC3 & 5.40 & $7.07 \times 10^{-05}$ & $\begin{array}{l}\text { Subunidad altamente conservada de } \\
\text { portador de piruvato mitocondrial(MPC) }\end{array}$ \\
\hline YGL010W & MPO1 & 5.35 & $7.58 \times 10^{-06}$ & $\begin{array}{c}\text { Proteína implicada en el metabolismo de } \\
\text { fitoesfingosina }\end{array}$ \\
\hline YDR513W & $\mathrm{GRX} 2$ & 5.09 & $6.09 \times 10^{-03}$ & Glutaredoxina citoplásmica \\
\hline YHR179W & OYE2 & 5.09 & $1.04 \times 10^{-02}$ & $\begin{array}{l}\text { NADPH oxidorreductasa conservada que } \\
\text { contiene mononucleótido de flavina (FMN) }\end{array}$ \\
\hline YDR059C & UBC5 & 5.05 & $2.39 \times 10^{-04}$ & Enzima conjugadora de ubiquitina \\
\hline YMR276W & DSK2 & 5.02 & $5.01 \times 10^{-03}$ & $\begin{array}{c}\text { Proteína de unión a poliubiquitina de tipo } \\
\text { ubiquitina enriquecida en núcleos }\end{array}$ \\
\hline
\end{tabular}

Tabla 2. Genes sobreexpresados con FC>5 en tratamiento con 200ppm de OTA.

\begin{tabular}{|c|c|c|c|c|}
\hline Gen & $\begin{array}{l}\text { Nomenclatur } \\
\text { a Standard }\end{array}$ & FC & p-value & Descripción \\
\hline YER106W & MAM1 & 60.19 & $2.77 \times 10^{-08}$ & Monopolin \\
\hline YGR225W & AMA1 & 57.40 & $9.19 \times 10^{-10}$ & $\begin{array}{c}\text { Activador del complejo promotor de } \\
\text { anafase meiótica (APC/C) }\end{array}$ \\
\hline YER179W & DMC1 & 40.52 & $5.34 \times 10^{-07}$ & Recombinasa específica de meiosis \\
\hline YOR298W & MUM3 & 33.53 & $9.62 \times 10^{-04}$ & $\begin{array}{c}\text { Proteína de función desconocida implicada } \\
\text { en la organización de la pared externa de } \\
\text { esporas }\end{array}$ \\
\hline YFL011W & HXT10 & 33.21 & $1.38 \times 10^{-07}$ & Transportador de hexosa putativo \\
\hline YLL046C & RNP1 & 27.33 & $1.08 \times 10^{-07}$ & Ribonucleoproteína \\
\hline YER104W & RTT105 & 25.99 & $3.22 \times 10^{-08}$ & $\begin{array}{l}\text { Proteína con papel en regulación de la } \\
\text { transposición de Ty1 }\end{array}$ \\
\hline YLR377C & FBP1 & 23.34 & $1.62 \times 10^{-07}$ & Fructosa-1,6-bisfosfatasa \\
\hline YDR523C & SPS1 & 22.72 & $6.27 \times 10^{-06}$ & Kinasa serina/treonina \\
\hline YHR176W & FMO1 & 20.24 & $1.11 \times 10^{-05}$ & Monooxigenasa que contiene flavina \\
\hline YBR040W & FIG1 & 19.70 & $1.16 \times 10^{-07}$ & Proteína integral de membrana \\
\hline YGR059W & SPR3 & 18.63 & $4.74 \times 10^{-05}$ & Septina involucrada en esporulación \\
\hline YEL039C & CYC7 & 16.86 & $6.54 \times 10^{-07}$ & Citocromo c isoforma 2 \\
\hline YMR101C & SRT1 & 16.73 & $3.73 \times 10^{-07}$ & $\begin{array}{l}\text { Forma complejo dehidrodolicil difosfato } \\
\text { syntasa (DDS) con NUS1 }\end{array}$ \\
\hline YDR218C & SPR28 & 14.07 & $1.11 \times 10^{-06}$ & Septina meiótica \\
\hline YDR256C & CTA1 & 13.47 & $7.51 \times 10^{-08}$ & Catalasa A \\
\hline YIL113W & SDP1 & 13.28 & $2.62 \times 10^{-07}$ & $\begin{array}{l}\text { MAP kinasa fosfatasade especidad dual } \\
\text { estrés-inducible }\end{array}$ \\
\hline YOL123W & HRP1 & 12.89 & $1.98 \times 10^{-06}$ & $\begin{array}{l}\text { Subunidad del complejo del factor de } \\
\text { escisión I }\end{array}$ \\
\hline YGL254W & FZF1 & 12.55 & $2.03 \times 10^{-07}$ & $\begin{array}{l}\text { Factor de transcripción implicado en el } \\
\text { metabolismo del sulfito }\end{array}$ \\
\hline YPL201C & YIG1 & 12.44 & $3.23 \times 10^{-05}$ & $\begin{array}{l}\text { Proteína que interactúa con glicerol 3- } \\
\text { fosfatasa }\end{array}$ \\
\hline
\end{tabular}




\begin{tabular}{|c|c|c|c|c|}
\hline Q0275 & $\operatorname{cox} 3$ & 12.31 & $1.01 \times 10^{-04}$ & $\begin{array}{c}\text { Subunidad III de citocromo c oxidasa } \\
\text { (Complejo IV) }\end{array}$ \\
\hline YFL055W & AGP3 & 12.31 & $2.34 \times 10^{-06}$ & Permeasa de aminoácidos de baja afinidad \\
\hline YDR259C & YAP6 & 11.37 & $1.88 \times 10^{-05}$ & $\begin{array}{l}\text { Factor de transcripción basic leucine zipper } \\
\text { (bZIP) }\end{array}$ \\
\hline YPR193C & HPA2 & 11.29 & $2.74 \times 10^{-05}$ & Histona tetramérica acetiltransferasa \\
\hline YOR378W & AMF1 & 11.28 & $2.33 \times 10^{-06}$ & Transportador NH4+ de baja afinidad \\
\hline YLL042C & ATG10 & 11.26 & $3.47 \times 10^{-06}$ & Enzima de conjugación tipo E2 conservada \\
\hline YIL101C & XBP1 & 11.07 & $3.43 \times 10^{-04}$ & Represor transcripcional \\
\hline YBR018C & GAL7 & 10.98 & $2.12 \times 10^{-05}$ & Galactosa-1-fosfato uridil transferasa \\
\hline YEL019C & MMS21 & 10.92 & $6.11 \times 10^{-06}$ & $\begin{array}{c}\text { SUMO ligasa y componente del complejo } \\
\text { SMC5-SMC6 }\end{array}$ \\
\hline YPR040W & TIP41 & 10.90 & $3.19 \times 10^{-05}$ & Proteína que interactúa con Tap42p \\
\hline YPL033C & SRL4 & 10.70 & $1.75 \times 10^{-06}$ & Proteína de función desconocida \\
\hline YLL057C & JLP1 & 10.48 & $1.82 \times 10^{-06}$ & $\begin{array}{l}\text { Sulfonato/alfa-ketoglutarato dioxigenasa } \\
\text { Fe(II)-dependiente }\end{array}$ \\
\hline YGR142W & BTN2 & 10.34 & $2.34 \times 10^{-05}$ & Proteína de unión v-SNARE \\
\hline YPL279C & FEX2 & 10.33 & $2.64 \times 10^{-07}$ & Proteína implicada en exportación de flúor \\
\hline YHL022C & SPO11 & 10.16 & $2.70 \times 10^{-07}$ & Proteína específica de meiosis \\
\hline YKL055C & OAR1 & 10.00 & $2.10 \times 10^{-06}$ & $\begin{array}{l}\text { 3-oxoacil-[proteína transportadora de acil] } \\
\text { reductasa mitocondrial }\end{array}$ \\
\hline YNL009W & IDP3 & 9.97 & $1.42 \times 10^{-02}$ & $\begin{array}{l}\text { NADP-dependiente isocitrato } \\
\text { deshidrogenasa peroxisomal }\end{array}$ \\
\hline YOR297C & TIM18 & 9.86 & $3.75 \times 10^{-05}$ & $\begin{array}{l}\text { Componente del complejo mitocondrial } \\
\qquad \mathrm{TIM} 22\end{array}$ \\
\hline YER053C-A & & 9.82 & $7.45 \times 10^{-06}$ & Proteína de función desconocida \\
\hline YPL027W & SMA1 & 9.67 & $1.50 \times 10^{-07}$ & Proteína de función desconocida \\
\hline YBR074W & PFF1 & 9.60 & $5.70 \times 10^{-06}$ & $\begin{array}{l}\text { Proteasa de membrana vacuolar multi- } \\
\text { spanning }\end{array}$ \\
\hline YEL048C & TCA17 & 9.59 & $2.14 \times 10^{-07}$ & $\begin{array}{l}\text { Componente del complejo de partículas de } \\
\text { transporte de proteínas (TRAPP) II }\end{array}$ \\
\hline YGR197C & SNG1 & 9.23 & $7.32 \times 10^{-08}$ & $\begin{array}{c}\text { Proteína implicada en resistencia a } \\
\text { nitrosoguanidina y 6-azauracil }\end{array}$ \\
\hline YJR047C & ANB1 & 9.17 & $1.29 \times 10^{-06}$ & Factor de elongación de traducción elF-5A \\
\hline YKL093W & MBR1 & 9.05 & $3.41 \times 10^{-05}$ & $\begin{array}{l}\text { Proteína involucrada en funciones } \\
\text { mitocondriales y respuesta al estrés }\end{array}$ \\
\hline YGR212W & SLI1 & 9.01 & $2.03 \times 10^{-05}$ & $\mathrm{~N}$-acetiltransferasa \\
\hline YCL026C-A & FRM2 & 8.77 & $1.66 \times 10^{-06}$ & Nitroreductasa tipo II \\
\hline YEL072W & RMD6 & 8.73 & $6.39 \times 10^{-07}$ & Proteína requerida para la esporulación \\
\hline YML054C & CYB2 & 8.51 & $2.74 \times 10^{-06}$ & $\begin{array}{c}\text { Citocromo b2 (L-lactato citocromo-c } \\
\text { oxidoreductasa) }\end{array}$ \\
\hline YNL187W & SWT21 & 8.48 & $6.08 \times 10^{-06}$ & $\begin{array}{l}\text { Proteína implicada en el ayuste (splicing) de } \\
\text { ARNm }\end{array}$ \\
\hline YNR064C & & 8.46 & $1.99 \times 10^{-05}$ & Epóxido hidrolasa \\
\hline YBR065C & ECM2 & 8.43 & $9.49 \times 10^{-06}$ & Factor de splicing pre-ARNm \\
\hline YPL171C & OYE3 & 8.39 & $6.43 \times 10^{-06}$ & $\begin{array}{l}\text { NADPH oxidoreductasa con flavina } \\
\text { mononucleótido (FMN) }\end{array}$ \\
\hline YGL212W & VAM7 & 8.37 & $1.02 \times 10^{-04}$ & Proteína vacuolar SNARE \\
\hline YOR390W & FEX1 & 8.17 & $3.59 \times 10^{-06}$ & Proteína implicada en exportación de flúor \\
\hline YMR069W & NAT4 & 8.05 & $1.76 \times 10^{-04}$ & $\mathrm{~N}$-alfa-acetil-transferasa \\
\hline YDL020C & RPN4 & 8.04 & $3.51 \times 10^{-07}$ & $\begin{array}{l}\text { Factor de transcripción estimulador de } \\
\text { expresión de genes del proteosoma }\end{array}$ \\
\hline
\end{tabular}




\begin{tabular}{|c|c|c|c|c|}
\hline YDR171W & HSP42 & 8.02 & $6.87 \times 10^{-06}$ & $\begin{array}{l}\text { Proteína de choque térmico pequeña (sHSP) } \\
\text { con actividad chaperona }\end{array}$ \\
\hline YER054C & GIP2 & 7.89 & $2.59 \times 10^{-06}$ & $\begin{array}{c}\text { Subunidad reguladora putativa de la } \\
\text { proteína fosfatasa Glc7p }\end{array}$ \\
\hline YPR151C & SUE1 & 7.89 & $9.84 \times 10^{-07}$ & $\begin{array}{l}\text { Proteína requerida para la degradación de } \\
\text { formas inestables de citocromo c }\end{array}$ \\
\hline YGR131W & FHN1 & 7.66 & $1.62 \times 10^{-06}$ & Proteína de función desconocida \\
\hline YEL061C & CIN8 & 7.64 & $1.15 \times 10^{-05}$ & Proteína motora kinesina \\
\hline YDR079W & PET100 & 7.63 & $4.29 \times 10^{-06}$ & $\begin{array}{l}\text { Chaperona que facilita específicamente el } \\
\text { ensamblaje de citocromo c oxidasa }\end{array}$ \\
\hline YKL051W & SFK1 & 7.56 & $1.38 \times 10^{-04}$ & $\begin{array}{c}\text { Proteína de membrana plasmática para } \\
\text { normalizar niveles de PI4P }\end{array}$ \\
\hline YMR017W & SPO20 & 7.52 & $1.72 \times 10^{-03}$ & $\begin{array}{l}\text { Subunidad específica de meiosis del } \\
\text { complejo t-SNARE }\end{array}$ \\
\hline YDR011W & SNQ2 & 7.49 & $4.53 \times 10^{-07}$ & $\begin{array}{l}\text { Transportador de membrana plasmática } \\
\text { ATP-binding cassette (ABC) }\end{array}$ \\
\hline YOR152C & ATG40 & 7.43 & $4.01 \times 10^{-05}$ & $\begin{array}{l}\text { Receptor de autofagia con un papel en la } \\
\text { degradación del RE }\end{array}$ \\
\hline YLR312C & ATG39 & 7.41 & $2.53 \times 10^{-07}$ & $\begin{array}{l}\text { Receptor de autofagia con un papel en la } \\
\text { degradación de la RE y el núcleo }\end{array}$ \\
\hline YBL078C & ATG8 & 7.33 & $7.40 \times 10^{-07}$ & $\begin{array}{l}\text { Componente de autofagosomas y vesículas } \\
\text { Cvt }\end{array}$ \\
\hline YPL186C & UIP4 & 7.19 & $4.47 \times 10^{-04}$ & Proteína que interactúa con Ulp1p \\
\hline YLR142W & PUT1 & 7.08 & $2.11 \times 10^{-06}$ & Prolina oxidasa \\
\hline YOR065W & CYT1 & 7.03 & $4.71 \times 10^{-05}$ & Citocromo c1 \\
\hline YOL149W & DCP1 & 6.99 & $1.35 \times 10^{-03}$ & $\begin{array}{l}\text { Subunidad del complejo enzimático de } \\
\text { decapping Dcp1p-Dcp2p }\end{array}$ \\
\hline Q0250 & $\operatorname{cox} 2$ & 6.68 & $3.78 \times 10^{-02}$ & $\begin{array}{l}\text { Subunidad II de citocromo c oxidasa } \\
\text { (Complejo IV) }\end{array}$ \\
\hline YDR402C & DIT2 & 6.62 & $1.08 \times 10^{-03}$ & $\mathrm{~N}$-formiltirosina oxidasa \\
\hline YGR243W & MPC3 & 6.60 & $1.70 \times 10^{-05}$ & $\begin{array}{l}\text { Subunidad altamente conservada del } \\
\text { transportador de piruvato mitocondrial } \\
\text { (MPC) }\end{array}$ \\
\hline YOR005C & DNL4 & 6.56 & $5.57 \times 10^{-06}$ & ADN ligasa \\
\hline YJR010W & MET3 & 6.56 & $9.83 \times 10^{-07}$ & ATP sulfurilasa \\
\hline YLR151C & PCD1 & 6.52 & $2.79 \times 10^{-06}$ & 8-oxo-dGTP difosfatasa \\
\hline YNL158W & PGA1 & 6.33 & $4.04 \times 10^{-04}$ & $\begin{array}{c}\text { Componente esencial de GPI- } \\
\text { manosiltransferasa II }\end{array}$ \\
\hline YDR524C & AGE1 & 6.32 & $8.02 \times 10^{-07}$ & $\begin{array}{l}\text { Proteína activadora de GTPasa (GAP) para } \\
\text { los factores de ribosilación de ADP (ARF) }\end{array}$ \\
\hline YNL012W & SPO1 & 6.31 & $4.68 \times 10^{-06}$ & Proteína proespora específica de meiosis \\
\hline YGL240W & DOC1 & 6.30 & $6.44 \times 10^{-05}$ & Factor de procesividad \\
\hline YDR076W & RAD55 & 6.29 & $1.32 \times 10^{-04}$ & $\begin{array}{l}\text { Proteína que estimula el intercambio de } \\
\text { cadena }\end{array}$ \\
\hline YOR192C & THI72 & 6.29 & $7.85 \times 10^{-06}$ & $\begin{array}{l}\text { Transportador de tiamina o compuesto } \\
\text { relacionado }\end{array}$ \\
\hline YMR251W & GTO3 & 6.26 & $2.35 \times 10^{-05}$ & Glutatión transferasa de clase omega \\
\hline YDR185C & UPS3 & 6.19 & $4.77 \times 10^{-06}$ & $\begin{array}{l}\text { Proteína mitocondrial de función } \\
\text { desconocida }\end{array}$ \\
\hline YNL014W & HEF3 & 6.19 & $1.32 \times 10^{-04}$ & Factor de elongación de traducción EF-3 \\
\hline YML087C & AIM33 & 6.17 & $1.01 \times 10^{-04}$ & Proteína de función desconocida \\
\hline YNR034W & SOL1 & 6.16 & $7.19 \times 10^{-07}$ & $\begin{array}{l}\text { Proteína con posible papel en exportación } \\
\text { de ARNt }\end{array}$ \\
\hline
\end{tabular}




\begin{tabular}{|c|c|c|c|c|}
\hline YDR070C & FMP16 & 6.13 & $3.24 \times 10^{-04}$ & Proteína de función desconocida \\
\hline YJR129C & EFM3 & 6.08 & $4.06 \times 10^{-02}$ & $\begin{array}{l}\text { Metiltransferasa dependiente de S- } \\
\text { adenosilmetionina }\end{array}$ \\
\hline Q0045 & $\operatorname{cox} 1$ & 6.04 & $176 \times 10^{-02}$ & $\begin{array}{l}\text { Subunidad I de citocromo c oxidasa } \\
\text { (Complejo IV) }\end{array}$ \\
\hline YNL036W & NCE103 & 5.90 & $4.88 \times 10^{-05}$ & Anhidrasa carbónica \\
\hline YOR178C & GAC1 & 5.86 & $6.08 \times 10^{-04}$ & $\begin{array}{l}\text { Subunidad reguladora para la proteína } \\
\text { fosfatasa tipo } 1 \text { (PP1) Glc7p }\end{array}$ \\
\hline YGR088W & CTT1 & 5.85 & $8.13 \times 10^{-05}$ & Catalasa T citosólica \\
\hline YDL247W & MPH2 & 5.83 & $2.28 \times 10^{-05}$ & Alfa-glucósido permeasa \\
\hline YCL066W & HMLALPHA1 & 5.74 & $6.90 \times 10^{-04}$ & Copia silenciada de ALPHA1 en HML \\
\hline YNL077W & APJ1 & 5.64 & $3.33 \times 10^{-06}$ & $\begin{array}{l}\text { Chaperona con papel en degradación de } \\
\text { proteínas mediada por SUMO }\end{array}$ \\
\hline YKL095W & YJU2 & 5.61 & $1.29 \times 10^{-03}$ & $\begin{array}{c}\text { Proteína esencial requerida para splicing } \\
\text { pre-ARNm }\end{array}$ \\
\hline YJL030W & MAD2 & 5.61 & $1.64 \times 10^{-04}$ & $\begin{array}{l}\text { Componente del complejo de control de } \\
\text { ensamblaje del huso }\end{array}$ \\
\hline YHL016C & DUR3 & 5.58 & $9.87 \times 10^{-07}$ & $\begin{array}{c}\text { Transportador de membrana plasmática } \\
\text { para urea y poliaminas }\end{array}$ \\
\hline YNL188W & KAR1 & 5.57 & $1.64 \times 10^{-04}$ & $\begin{array}{l}\text { Proteína implicada en cariogamia y } \\
\text { duplicación del cuerpo del polo del huso }\end{array}$ \\
\hline YGR234W & YHB1 & 5.56 & $1.02 \times 10^{-05}$ & Oxidoreductasa de óxido nítrico \\
\hline YCR040W & MATALPHA1 & 5.54 & $6.76 \times 10^{-04}$ & $\begin{array}{l}\text { Coactivador transcripcional que regula } \\
\text { genes específicos de apareamiento }\end{array}$ \\
\hline YFL016C & MDJ1 & 5.48 & $2.05 \times 10^{-04}$ & $\begin{array}{l}\text { Co-chaperona que estimula la actividad } \\
\text { Ssc1p ATPasa de la proteína HSP70 }\end{array}$ \\
\hline YNL194C & & 5.39 & $4.89 \times 10^{-04}$ & $\begin{array}{l}\text { Proteína integral de membrana requerida } \\
\text { para esporulación y contenido de } \\
\text { esfingolípidos en la membrana plasmática }\end{array}$ \\
\hline YDR475C & JIP4 & 5.30 & $2.01 \times 10^{-03}$ & Proteína de función desconocida \\
\hline YJR160C & MPH3 & 5.29 & $8.87 \times 10^{-05}$ & Alfa-glucósido permeasa \\
\hline YCR104W & PAU3 & 5.25 & $1.92 \times 10^{-03}$ & $\begin{array}{l}\text { Miembro de la familia multigénica } \\
\text { seripauperina }\end{array}$ \\
\hline YIL084C & SDS3 & 5.25 & $6.30 \times 10^{-06}$ & $\begin{array}{l}\text { Componente del complejo de histona } \\
\text { deacetilasa Rpd3L }\end{array}$ \\
\hline YIL056W & VHR1 & 5.15 & $3.53 \times 10^{-03}$ & Activador transcripcional \\
\hline YAR020C & PAU7 & 5.01 & $1.56 \times 10^{-04}$ & $\begin{array}{l}\text { Miembro de la familia multigénica } \\
\text { seripauperina }\end{array}$ \\
\hline YDR227W & SIR4 & 5.01 & $1.71 \times 10^{-05}$ & Regulador de silenciamiento \\
\hline YLR376C & PSY3 & 5.00 & $6.70 \times 10^{-06}$ & $\begin{array}{l}\text { Componente del complejo Shu (complejo } \\
\text { PCSS) }\end{array}$ \\
\hline
\end{tabular}

Tabla 3. Genes sobreexpresados con FC $>5$ en tratamiento combinado de CIT/OTA.

\begin{tabular}{ccccc}
\hline Gen & $\begin{array}{c}\text { Nomenclatur } \\
\text { a Standard }\end{array}$ & FC & p-value & Descripción \\
\hline YPL171C & OYE3 & 199.63 & $1.29 \times 10^{-04}$ & $\begin{array}{c}\text { NADPH oxidoreductasa con flavina } \\
\text { mononucleótido (FMN) }\end{array}$ \\
YDL243C & AAD4 & 46.48 & $1.49 \times 10^{-09}$ & Aryl-alcohol deshidrogenasa putativa \\
YFL056C & AAD6 & 41.25 & $1.16 \times 10^{-07}$ & Aryl-alcohol deshidrogenasa putativa \\
YLL060C & GTT2 & 34.58 & $1.44 \times 10^{-09}$ & $\begin{array}{c}\text { Glutatión S-transferasa } \\
\text { YBR008C }\end{array}$ \\
\hline
\end{tabular}




\begin{tabular}{|c|c|c|c|c|}
\hline YML131W & & 24.18 & $2.41 \times 10^{-06}$ & $\begin{array}{l}\text { plasmática de la Major Facilitator } \\
\text { Superfamily(MFS) } \\
\text { Proteína de función desconocida }\end{array}$ \\
\hline YOL151W & GRE2 & 21.89 & $1.17 \times 10^{-04}$ & $\begin{array}{l}\text { Reductasa 3-metilbutanal y } \\
\text { reductasametilglioxal NADPH-dependiente }\end{array}$ \\
\hline YCL026C-A & FRM2 & 21.51 & $1.53 \times 10^{-08}$ & Nitroreductasa tipo II \\
\hline YMR101C & SRT1 & 21.35 & $2.64 \times 10^{-08}$ & $\begin{array}{l}\text { Forma complejo dehidrodolicil difosfato } \\
\text { syntasa (DDS) con NUS1 }\end{array}$ \\
\hline YGR225W & AMA1 & 20.53 & $3.87 \times 10^{-07}$ & $\begin{array}{l}\text { Activador del complejo promotor de anafase } \\
\text { meiótica (APC/C) }\end{array}$ \\
\hline YDL020C & RPN4 & 19.49 & $4.24 \times 10^{-04}$ & $\begin{array}{l}\text { Factor de transcripción estimulador de } \\
\text { expresión de genes de proteosoma }\end{array}$ \\
\hline YDR256C & CTA1 & 18.79 & $4.53 \times 10^{-09}$ & Catalasa A \\
\hline YGR197C & SNG1 & 18.75 & $5.35 \times 10^{-09}$ & $\begin{array}{c}\text { Proteína implicada en resistencia a } \\
\text { nitrosoguanidina y 6-azauracil }\end{array}$ \\
\hline YKL051W & SFK1 & 18.67 & $6.62 \times 10^{-08}$ & $\begin{array}{c}\text { Proteína de membrana plasmática para } \\
\text { normalizar niveles de PI4P }\end{array}$ \\
\hline YML116W & ATR1 & 16.26 & $9.44 \times 10^{-06}$ & $\begin{array}{l}\text { Bomba de eflujo multidroga de la Major } \\
\text { Facilitator Superfamily (MFS) }\end{array}$ \\
\hline YGR142W & BTN2 & 15.23 & $7.12 \times 10^{-06}$ & Proteína de unión v-SNARE \\
\hline YHR087W & RTC3 & 14.98 & $1.01 \times 10^{-06}$ & $\begin{array}{l}\text { Proteína de función desconocida implicada en } \\
\text { el metabolismo del ARN }\end{array}$ \\
\hline YDR406W & PDR15 & 14.21 & $3.31 \times 10^{-06}$ & $\begin{array}{c}\text { Transportador de membrana plasmática ATP- } \\
\text { binding cassette }(\mathrm{ABC})\end{array}$ \\
\hline YFL057C & AAD16 & 13.74 & $1.51 \times 10^{-05}$ & Aryl-alcohol deshidrogenasa putativa \\
\hline YOL149W & DCP1 & 13.54 & $3.61 \times 10^{-05}$ & $\begin{array}{l}\text { Subunidad del complejo enzimático decapping } \\
\qquad \text { Dcp1p-Dcp2p }\end{array}$ \\
\hline YDR171W & HSP42 & 13.52 & $1.19 \times 10^{-03}$ & $\begin{array}{l}\text { Proteína de choque térmico pequeña (sHSP) } \\
\text { con actividad chaperona }\end{array}$ \\
\hline YIL101C & XBP1 & 12.35 & $3.01 \times 10^{-05}$ & Represor transcripcional \\
\hline YHR139C & SPS100 & 12.29 & $1.95 \times 10^{-07}$ & $\begin{array}{l}\text { Proteína requerida en maduración de la pared } \\
\text { de esporas }\end{array}$ \\
\hline YGR213C & RTA1 & 12.11 & $1.04 \times 10^{-08}$ & $\begin{array}{c}\text { Proteína involucrada en resistencia a 7- } \\
\text { aminocolesterol }\end{array}$ \\
\hline YEL039C & CYC7 & 11.83 & $4.14 \times 10^{-08}$ & Citocromo c isoforma 2 \\
\hline YIL056W & VHR1 & 10.52 & $4.95 \times 10^{-07}$ & Activador transcripcional \\
\hline YCL026C-B & HBN1 & 10.47 & $8.33 \times 10^{-06}$ & Proteína de función desconocida \\
\hline YOL123W & HRP1 & 10.36 & $2.81 \times 10^{-06}$ & Subunidad del complejo del factor de escisión I \\
\hline YHL036W & MUP3 & 9.54 & $6.44 \times 10^{-07}$ & Permeasa de baja afinidad a metionina \\
\hline YKR076W & ECM4 & 9.40 & $4.12 \times 10^{-07}$ & Glutatión transferasa clase omega \\
\hline YLR108C & & 9.06 & $3.50 \times 10^{-07}$ & Proteína de función desconocida \\
\hline YER054C & GIP2 & 8.90 & $1.55 \times 10^{-07}$ & $\begin{array}{l}\text { Subunidad reguladora putativa de la proteína } \\
\text { fosfatasa Glc7p }\end{array}$ \\
\hline YOR298W & MUM3 & 8.85 & $3.49 \times 10^{-06}$ & $\begin{array}{l}\text { Proteína de función desconocida implicada en } \\
\text { la organización de la pared externa de esporas }\end{array}$ \\
\hline YHL024W & RIM4 & 8.59 & $4.31 \times 10^{-08}$ & Proteína de unión a ARN putativa \\
\hline YMR169C & ALD3 & 8.27 & $6.99 \times 10^{-03}$ & Aldehido deshidrogenasa citoplasmática \\
\hline YOR028C & CIN5 & 8.23 & $2.47 \times 10^{-07}$ & $\begin{array}{l}\text { Factor de transcripción basic leucine zipper } \\
\qquad \text { (bZIP) de la familia yAP-1 }\end{array}$ \\
\hline YGR088W & CTT1 & 8.10 & $3.34 \times 10^{-06}$ & Catalasa T citosólica \\
\hline YER103W & SSA4 & 7.96 & $1.02 \times 10^{-05}$ & $\begin{array}{l}\text { Proteína de choque térmico de la familia } \\
\text { HSP70 }\end{array}$ \\
\hline YER185W & PUG1 & 7.45 & $1.07 \times 10^{-05}$ & Proteína de membrana plasmática implicada \\
\hline
\end{tabular}




\begin{tabular}{|c|c|c|c|c|}
\hline & & & & en transporte de protoporfirina y hemo \\
\hline YER053C-A & & 7.21 & $1.56 \times 10^{-04}$ & Proteína de función desconocida \\
\hline YOR152C & ATG40 & 7.18 & $3.92 \times 10^{-05}$ & $\begin{array}{c}\text { Receptor de autofagia con un papel en la } \\
\text { degradación del RE }\end{array}$ \\
\hline YDL204W & RTN2 & 6.65 & $1.74 \times 10^{-06}$ & Proteína reticulón \\
\hline YOR065W & CYT1 & 6.60 & $4.43 \times 10^{-06}$ & Citocromo c1 \\
\hline YJL051W & IRC8 & 6.56 & $5.68 \times 10^{-05}$ & $\begin{array}{l}\text { Proteína de función desconocida localizada en } \\
\text { extremo de la yema }\end{array}$ \\
\hline YLR329W & REC102 & 6.54 & $4.83 \times 10^{-06}$ & $\begin{array}{l}\text { Proteína implicada en las primeras etapas de la } \\
\text { recombinación meiótica }\end{array}$ \\
\hline YKR077W & MSA2 & 6.42 & $6.97 \times 10^{-06}$ & Activador transcripcional putativo \\
\hline YHR138C & & 6.09 & $7.19 \times 10^{-03}$ & Proteína de función desconocida \\
\hline YPL201C & YIG1 & 5.99 & $4.46 \times 10^{-07}$ & $\begin{array}{l}\text { Proteína que interactúa con glicerol 3- } \\
\text { fosfatasa }\end{array}$ \\
\hline YDL025C & RTK1 & 5.97 & $3.61 \times 10^{-02}$ & Proteína kinasa putativa \\
\hline YOR178C & GAC1 & 5.89 & $9.69 \times 10^{-04}$ & $\begin{array}{l}\text { Subunidad reguladora para la proteína } \\
\text { fosfatasa tipo } 1 \text { (PP1) Glc7p }\end{array}$ \\
\hline YFL016C & MDJ1 & 5.81 & $4.14 \times 10^{-05}$ & $\begin{array}{c}\text { Co-chaperona que estimula la actividad Ssc1p } \\
\text { ATPasa de la proteína HSP70 }\end{array}$ \\
\hline YFL030W & AGX1 & 5.81 & $1.51 \times 10^{-06}$ & Alanina:glioxylato aminotransferasa (AGT) \\
\hline YKL086W & SRX1 & 5.78 & $5.28 \times 10^{-05}$ & Sulfiredoxina \\
\hline YOR328W & PDR10 & 5.76 & $1.96 \times 10^{-06}$ & $\begin{array}{l}\text { Transportador de membrana plasmática ATP- } \\
\text { binding cassette }(\mathrm{ABC})\end{array}$ \\
\hline YPR151C & SUE1 & 5.55 & $1.71 \times 10^{-07}$ & $\begin{array}{c}\text { Proteína requerida para la degradación de } \\
\text { formas inestables de citocromo c }\end{array}$ \\
\hline YLL026W & HSP104 & 5.54 & $4.85 \times 10^{-02}$ & Desagregasa \\
\hline YGR243W & MPC3 & 5.53 & $5.30 \times 10^{-05}$ & $\begin{array}{l}\text { Subunidad altamente conservada de portador } \\
\text { de piruvato mitocondrial(MPC) }\end{array}$ \\
\hline YKL093W & MBR1 & 5.53 & $2.19 \times 10^{-05}$ & $\begin{array}{l}\text { Proteína involucrada en funciones } \\
\text { mitocondriales y respuesta al estrés }\end{array}$ \\
\hline YNL036W & NCE103 & 5.51 & $5.13 \times 10^{-05}$ & Anhidrasa carbónica \\
\hline YNL008C & ASI3 & 5.46 & $1.69 \times 10^{-05}$ & $\begin{array}{l}\text { Subunidad de la membrana nuclear interna del } \\
\text { complejo ubiquitina ligasa Asi }\end{array}$ \\
\hline YLR343W & GAS2 & 5.45 & $4.37 \times 10^{-06}$ & 1,3-beta-glucanosiltransferasa \\
\hline YGR223C & HSV2 & 5.44 & $1.69 \times 10^{-06}$ & Proteína de unión a fosfoinosítido (PI) \\
\hline YER060W-A & $\mathrm{FCY} 22$ & 5.24 & $1.17 \times 10^{-05}$ & Purina-citosina permeasa putativa \\
\hline YNL155W & CUZ1 & 5.19 & $1.90 \times 10^{-03}$ & $\begin{array}{l}\text { Proteína con papel en ruta ubiquitina- } \\
\text { proteosoma }\end{array}$ \\
\hline YHL021C & AIM17 & 5.17 & $1.36 \times 10^{-04}$ & Proteína de función desconocida \\
\hline YHR199C & AIM46 & 5.16 & $1.08 \times 10^{-05}$ & Proteína de función desconocida \\
\hline YGR281W & YOR1 & 5.12 & $2.18 \times 10^{-03}$ & $\begin{array}{l}\text { Transportador de membrana plasmática ATP- } \\
\text { binding cassette }(\mathrm{ABC})\end{array}$ \\
\hline YGL010W & MPO1 & 5.07 & $3.53 \times 10^{-06}$ & $\begin{array}{c}\text { Proteína implicada en el metabolismo de } \\
\text { fitoesfingosina }\end{array}$ \\
\hline
\end{tabular}

En los distintos tratamientos el número de genes sobreexpresados variaron, así como sus grupos funcionales (Tabla 4). En la Tabla 1, donde las células se trataron con citrinina, se encontraron 70 genes sobreexpresados, cuyos grupos funcionales mayoritariamente están relacionados con la respuesta a estrés oxidativo, el más importante el implicado en el metabolismo del glutatión, conocido antioxidante, y en el transporte de drogas, 
mostrando la importancia de la detoxificación de la célula a través de los transportadores, especialmente Snq2, Pdr15, Pdr10, Pdr16, Yor1, Flr1, y Atr1. En la Tabla 2, correspondiente al tratamiento con OTA, se identificaron 115 genes, cuyos grupos funcionales están relacionados mayoritariamente con procesos de desarrollo celular, como esporulación y reproducción. En este caso, el único transportador de xenobióticos moderadamente activo fue Snq2. En la Tabla 3, correspondiente al tratamiento combinado, aparecen 68 genes sobreexpresados, cuyos grupos funcionales son una combinación de los dos tratamientos anteriores.

Tabla 4. Grupos funcionales de genes inducidos por tratamientos con CIT, OTA, y CIT/OTA.

\begin{tabular}{|c|c|}
\hline CIT & \multirow{2}{*}{$p$-value } \\
\hline Grupos Gene Ontology & \\
\hline Proceso de oxidación-reducción & $1.8 \times 10^{-13}$ \\
\hline Respuesta celular al estrés oxidativo & $2.2 \times 10^{-9}$ \\
\hline Proceso metabólico del glutatión & $1.8 \times 10^{-6}$ \\
\hline Transporte de drogas & $1.3 \times 10^{-5}$ \\
\hline Respuesta a especies reactivas de oxígeno & $1.3 \times 10^{-4}$ \\
\hline OTA & \multirow{2}{*}{$p$-value } \\
\hline Grupos Gene Ontology & \\
\hline Proceso de desarrollo de un organismo & $2.2 \times 10^{-8}$ \\
\hline Proceso de oxidación-reducción & $2.0 \times 10^{-7}$ \\
\hline Diferenciación celular & $3.0 \times 10^{-6}$ \\
\hline Proceso de desarrollo involucrado en la reproducción & $5.4 \times 10^{-6}$ \\
\hline Esporulación & $1.6 \times 10^{-5}$ \\
\hline Respuesta celular al estrés oxidativo & $5.4 \times 10^{-3}$ \\
\hline CIT + OTA & \multirow{2}{*}{$p$-value } \\
\hline Grupos Gene Ontology & \\
\hline Proceso de oxidación-reducción & $1.7 \times 10^{-7}$ \\
\hline Transporte de drogas & $1.3 \times 10^{-5}$ \\
\hline Respuesta celular al estrés oxidativo & $3.1 \times 10^{-4}$ \\
\hline Ensamblaje de la pared de esporas & $1.4 \times 10^{-3}$ \\
\hline Proceso de desarrollo de un organismo & $4.2 \times 10^{-3}$ \\
\hline
\end{tabular}

Estos resultados mostraron diferencias significativas en la expresión génica celular en respuesta a los tratamientos con CIT y OTA. En la Figura 16 se observa que apenas 8 genes (menos del 5\%) del total de genes inducidos con estas toxinas, son compartidos en ambos tratamientos, y que están relacionados con procesos de oxidación-reducción. El hecho de que estas micotoxinas inducen distintos grupos de genes, parece indicar que podrían tener distintos efectos biológicos en las células. 


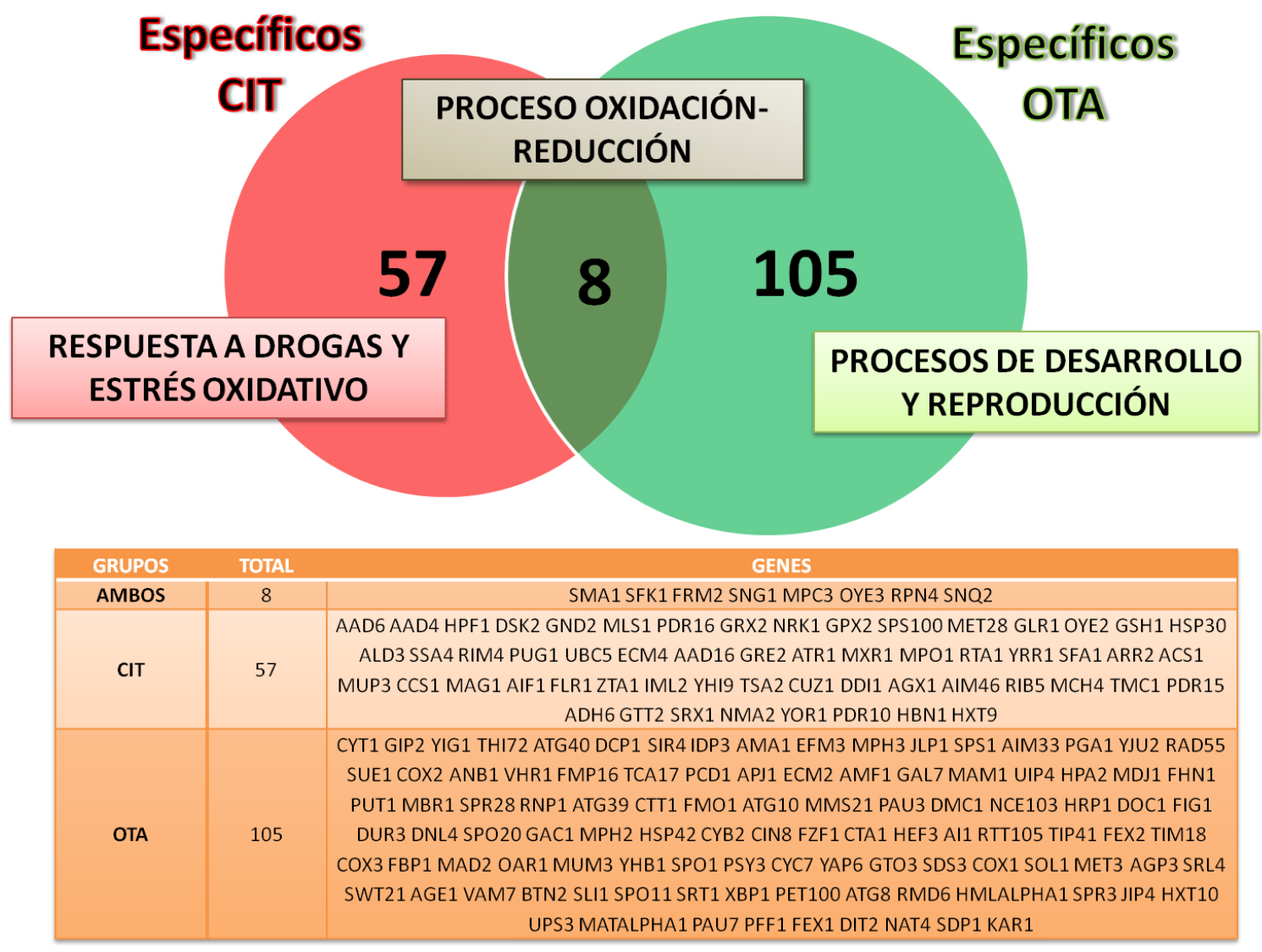

Figura 16. Comparación de genes inducidos en tratamientos con CIT y OTA con un diagrama de Venn. Se compararon los genes inducidos con FC $>5$ para los tratamientos por separado de CIT (rojo) y OTA (verde). La lista de genes inducidos, exclusivos y comunes, aparecen indicados en la tabla. Los grupos funcionales representativos de cada conjunto de genes se muestran en el diagrama.

\section{Estudio de la posible relación del estrés oxidativo con los efectos causados por citrinina y ocratoxina A.}

Los resultados de los experimentos transcriptómicos mostraron diferencias en la inducción de genes entre citrinina y ocratoxina A. En el caso de la exposición a CIT el conjunto mayoritario de genes inducidos estaba relacionado con la respuesta a estrés oxidativo, así como con la eliminación de drogas mediante diversos transportadores, mientras que con OTA esta respuesta se observó de forma más débil.

Para conocer mejor la posible relación entre la respuesta a estrés oxidativo y extrusión de tóxicos con la exposición a CIT y OTA, se realizó, por un lado, un ensayo de sensibilidad con varios mutantes, y por otro lado, un estudio con reporteros luciferasa.

\subsection{Estudio de reporteros luciferasa GRE2-lucCP ${ }^{+}$, 3xAP1-lucCP ${ }^{+}$, y PDR5- lucCP ${ }^{+}$sometidos a CIT y OTA.}

En primer lugar, quisimos estudiar los efectos de CIT y OTA en reporteros inducibles por distintos estreses para conocer sus perfiles dosis-respuesta y ver las posibles diferencias entre ellos. Para ello, empleamos el reportero integrativo PDR5-lucCP ${ }^{+}$ 
como control, ya que anteriormente vimos que Pdr5 se activa y participa en la respuesta a ambas micotoxinas. Además, utilizamos otros dos reporteros: GRE2-lucCP ${ }^{+}$, que también habíamos empleado antes y es inducible a estrés de forma general, y 3xAP1lucCP$^{+}$(Dolz-Edo et al. 2013), que es un reportero inducible específico de estrés oxidativo. Estos reporteros fueron sometidos a un rango de concentraciones de CIT y OTA y se cuantificó su actividad en luminómetro. Los perfiles dosis-respuesta resultantes se muestran en la Figura 17.
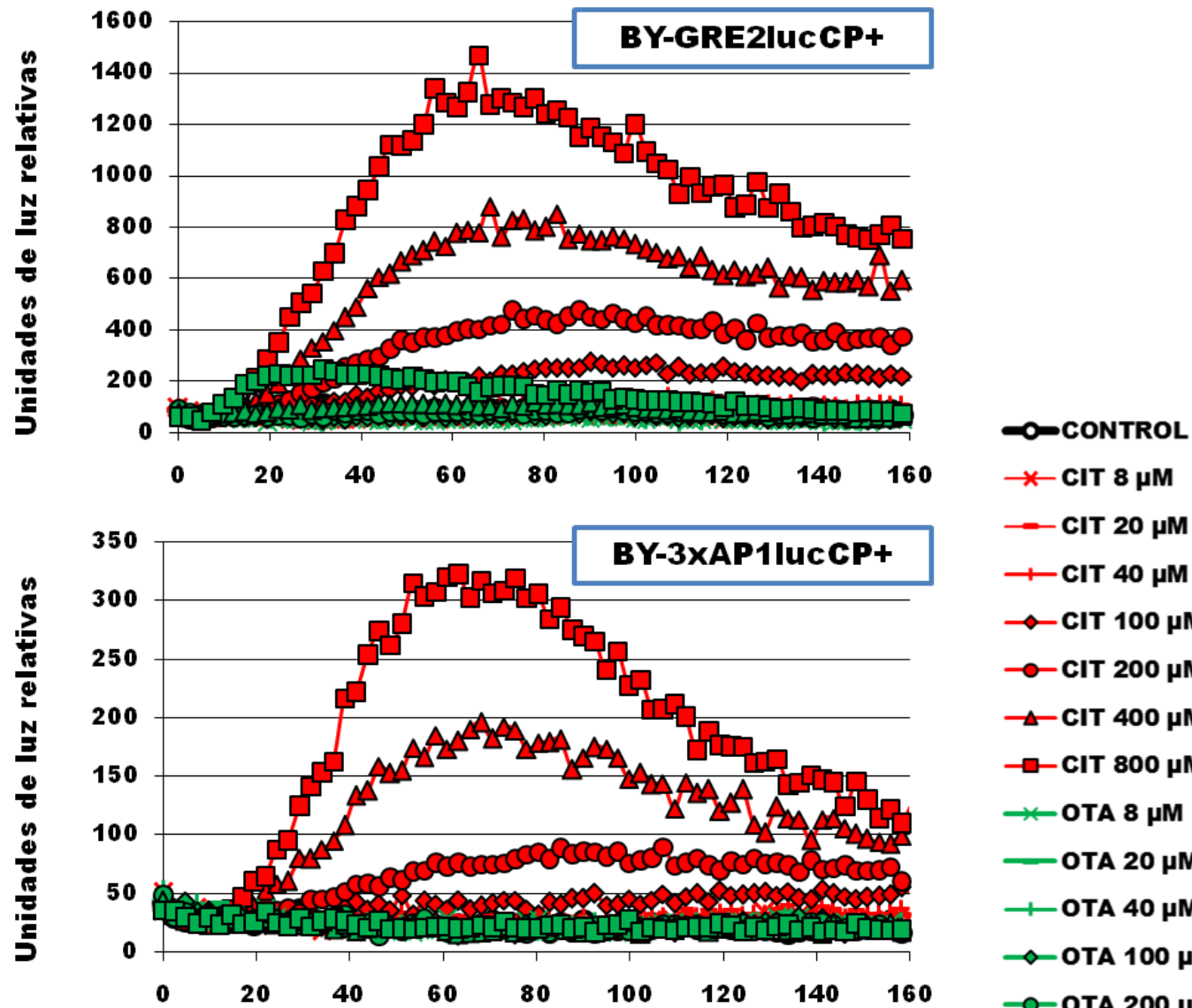

$\rightarrow$ CIT $8 \mu \mathrm{M}$

- CIT 20 нM

—CIT $40 \mu \mathrm{M}$

$\leadsto$ CIT $100 \mu \mathrm{M}$

- CIT $200 \mu \mathrm{M}$

$\triangle-$ CIT $400 \mu \mathrm{M}$

$\rightarrow$-CIT $800 \mu \mathrm{M}$

$\leftarrow$ OTA $8 \mu \mathrm{M}$

— OTA $20 \mu \mathrm{M}$

— OTA $40 \mu \mathrm{M}$

$\leadsto$ OTA $100 \mu \mathrm{M}$

-O-OTA $200 \mu \mathrm{M}$

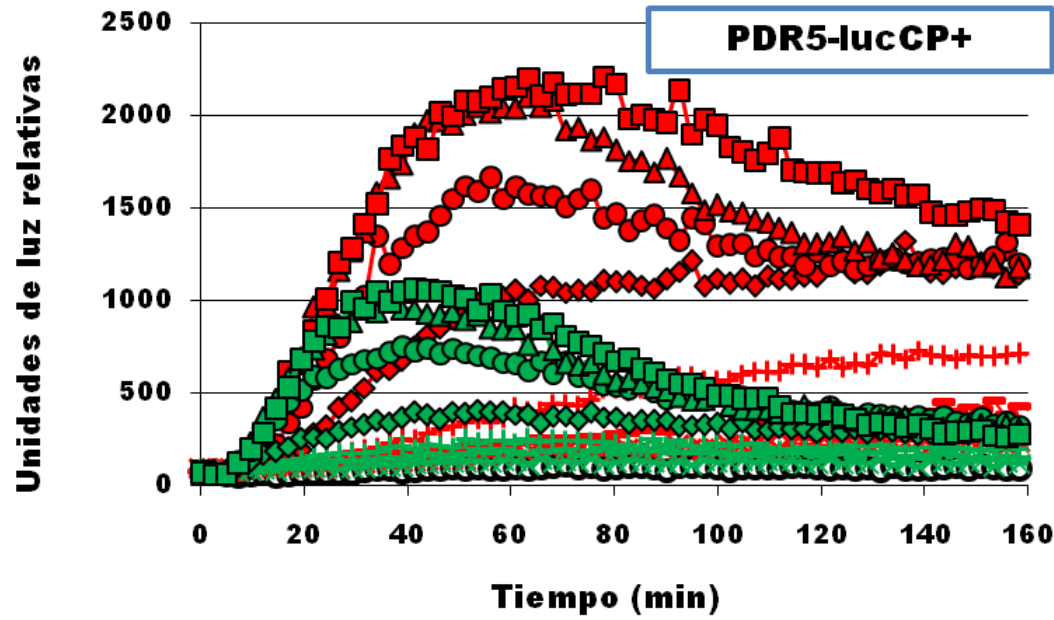

$\triangle$-ОTА $400 \mu \mathrm{M}$

$\neg$ ОTA $800 \mu \mathrm{M}$

Figura 17. OTA y CIT inducen reporteros de estrés de forma diferencial. Las células con las construcciones $\mathrm{GRE}-\mathrm{lucCP}^{+}, 3 \mathrm{xAP1}$-lucCP${ }^{+}$y PDR5-lucCP ${ }^{+}$se sometieron a un rango de concentraciones $(0,8,20,40,100,200$, 400 y $800 \mu \mathrm{M})$ de citrinina y ocratoxina A, y se cuantificó la actividad luciferasa con luminómetro por triplicado. Desviación estándar del ensayo no supera el $15 \%$. 
Los perfiles dosis-respuesta mostraron diferencias en función del reportero y la droga, aunque en todos los casos se observó una mayor actividad luciferasa en los tratamientos con citrinina y a medida que la concentración de micotoxina aumenta. Para poder comparar más fácilmente los tres reporteros representamos la actividad máxima (Amax) para cada concentración (Figura 18).

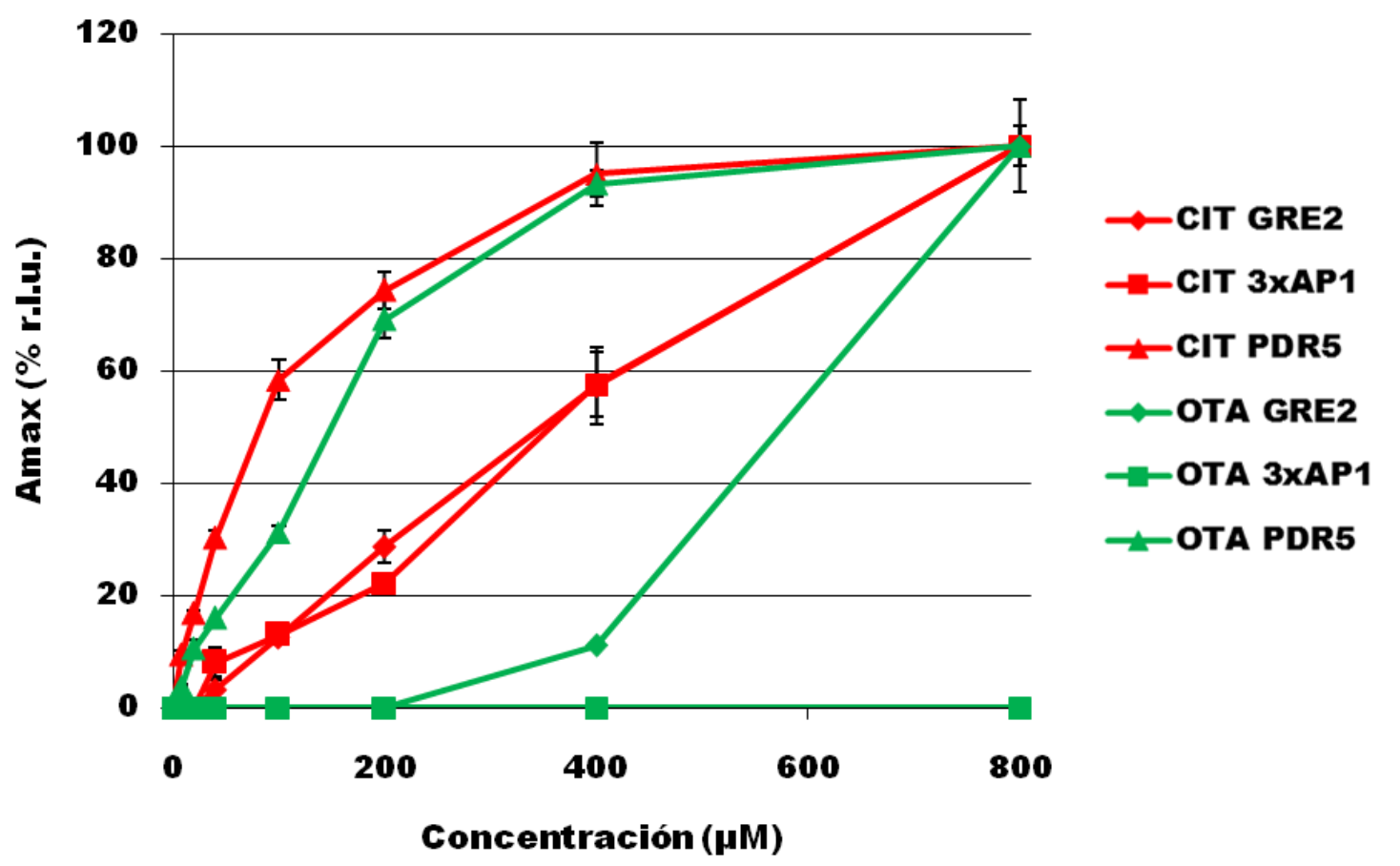

Figura 18. Actividad máxima (Amax) de los reporteros GRE2, 3xAP1, y PDR5-lucCP ${ }^{+}$. Representación de la Amax de los reporteros GRE2-lucCP ${ }^{+}, 3 x A P 1-l u c C P^{+}$y PDR5-luc $\mathrm{PP}^{+}$tratados con un rango de concentraciones $(0$, $8,20,40,100,200,400$ y $800 \mu \mathrm{M}$ ) de citrinina (rojo) y ocratoxina A (verde), y se cuantificó la actividad luciferasa con luminómetro por triplicado. Los valores máximos de actividad se representan frente a la concentración de micotoxina. Los valores Amax fueron ajustados sobre 100.

En la Figura 18 se observa que $P D R 5$ es inducido de forma similar por ambas micotoxinas, sin embargo, los reporteros específicos de estrés se inducen mayoritariamente cuando son tratados con citrinina. Concretamente, en el caso del reportero 3xAP1-lucCP ${ }^{+}$, cuyos elementos AP1 son exclusivos en respuesta a estrés oxidativo, sólo se induce con CIT.

Estos resultados apoyarían los obtenidos en los experimentos anteriores, donde se observaron diferencias entre CIT y OTA respecto a los genes inducidos en la respuesta celular adaptativa a estas micotoxinas, y que indican que CIT causa más específicamente daños oxidativos que OTA, de forma que hay una activación de genes implicados en la respuesta antioxidante. Para comprobar el efecto de esta activación a nivel génico, se decidió analizar estos resultados a nivel fenotípico empleando mutantes defectuosos en la adaptación a estrés oxidativo y transporte multidroga. 
3.2. CIT causa estrés oxidativo que se agrava en mutantes con defectos en la respuesta antioxidante.

Para conocer mejor la participación de determinadas proteínas implicadas en la respuesta antioxidante y cómo afecta al crecimiento de las células la exposición a citrinina y ocratoxina A, se estudió el efecto a nivel fenotípico de estas micotoxinas comparando células de la cepa silvestre con varios mutantes. Para ello, se realizó un ensayo de sensibilidad en medio sólido con mutantes defectuosos en la adaptación a estrés oxidativo ( $\Delta y a p 1, \Delta s k n 7)$ y en el transporte multidroga ( $\Delta s n q 2$ y $\Delta y o r l)$.

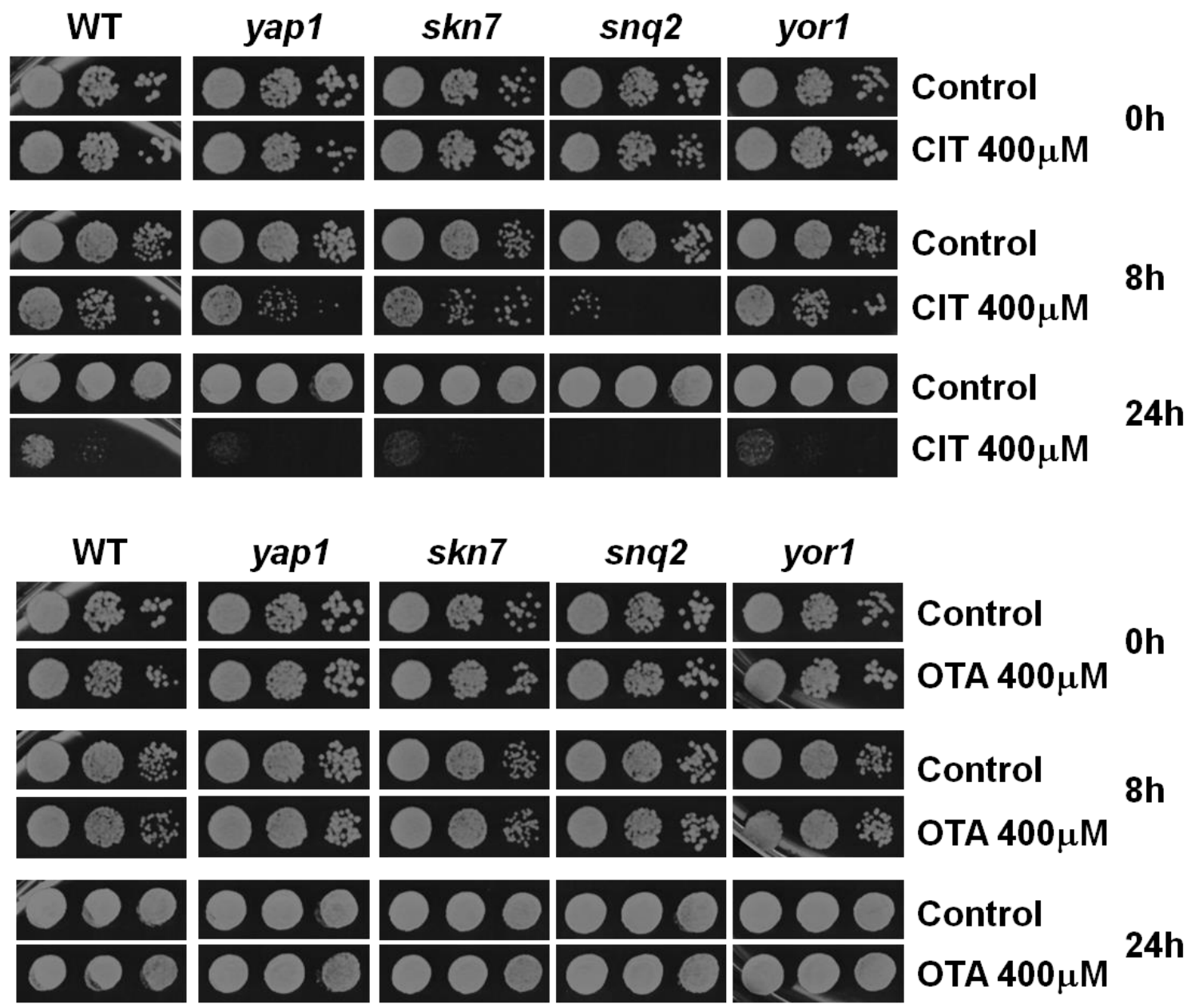

Figura 19. La toxicidad de CIT, pero no de OTA, aumenta en mutantes con defectos en la respuesta adaptativa a estrés oxidativo o el transporte multidroga. Los mutantes indicados fueron tratados o no con $400 \mu \mathrm{M}$ de CIT (panel superior) o 400 $\mathrm{M}$ de OTA (panel inferior). Se hicieron diluciones seriadas 1:1, 1:10, y 1:100 de los cultivos y plaquearon en los tiempos indicados en medio YPD sólido sin micotoxinas.

En la Figura 19 se observa que la falta del factor de transcripción de defensa a estrés oxidativo Yap1, así como del transportador multidroga Snq2 afecta a la viabilidad de las células frente a CIT a partir de $8 \mathrm{~h}$. Además, el efecto de esta toxina es notable en todos los casos a las 24h. Por el contrario, el tratamiento con OTA no parece afectar a ninguno de los mutantes estudiados. Estos resultados se corresponden con los ensayos anteriores, 
corroborando la diferencia tanto a nivel de activación génica como fenotípica en las células sometidas a estas dos micotoxinas.

En conjunto, estos resultados muestran que la exposición a las micotoxinas citrinina y ocratoxina A tiene efectos biológicos distintos en las células, es decir, los mecanismos de toxicidad son diferentes, desencadenando una respuesta de adaptación distinta frente a cada una de ellas. Los resultados en este trabajo muestran que CIT causa estrés oxidativo lo que da lugar a una respuesta transcripcional antioxidante y la expulsión de los compuestos tóxicos a través de los transportadores específicos de drogas de la membrana. Por su parte, OTA parece producir una desregulación de genes centrados en procesos del desarrollo, algunos habitualmente no expresados, como los genes implicados en la esporulación, y sólo induce levemente una respuesta antioxidante. 


\section{CAPÍTULO 2: ANÁLISIS EN TIEMPO REAL DE LA RESPUESTA MULTIDROGA EN LEVADURA: REGULACIÓN DIFERENCIAL DE LOS TRANSPORTADORES PDR Y SELECTIVIDAD DE LOS ACTIVADORES TRANSCRIPCIONALES INVOLUCRADOS.}

Las proteínas pertenecientes al sistema PDR (Pleiotropic Drug Resistance) son un grupo de proteínas con distintas funciones en la respuesta celular de adaptación a xenobióticos, y que se encuentran conservadas de bacterias a organismos eucarióticos superiores. Anteriormente, encontramos que diferentes transportadores de membrana están regulados de forma distinta ante la exposición a las micotoxinas citrinina (CIT) y ocratoxina A (OTA). En esta parte del presente trabajo, quisimos ampliar nuestros estudios de expresión génica con reporteros luciferasa al sistema de genes PDR de levadura. Así, estudiamos la expresión de ciertos transportadores de membrana y la contribución individual de varios activadores transcripcionales Pdr a la respuesta adaptativa de las células cuando son tratadas con diversos xenobióticos, entre ellos, las micotoxinas citrinina y ocratoxina A.

\section{Estudio transcripcional de los transportadores Pdr5, Pdr15, Snq2 y Yor1 tratados con varios xenobióticos.}

El sistema PDR responde a un amplio rango de moléculas xenobióticas estructural y funcionalmente distintas, en muchos casos hidrofóbicas, pero también otros estreses abióticos $\left(\mathrm{NaCl}, \mathrm{H}_{2} \mathrm{O}_{2}\right.$, etc.). En primer lugar, quisimos investigar una posible regulación diferencial de distintos transportadores de membrana de la superfamilia de proteínas $\mathrm{ABC}$ en respuesta a diferentes tratamientos tóxicos, concretamente, citrinina (CIT), ocratoxina A (OTA), menadiona (MEN) y peróxido de hidrógeno $\left(\mathrm{H}_{2} \mathrm{O}_{2}\right)$. Estudiamos la expresión de los transportadores de membrana multidroga Pdr5, Pdr15, Snq2, y Yor1, que según los resultados transcriptómicos del capítulo 1 se activan ante la presencia de CIT y en algunos casos también OTA. Para ello, empleamos los reporteros luciferasa integrativos PDR5-, PDR15-, SNQ2-, y YOR1-lucCP ${ }^{+}$y los sometimos a un rango de concentraciones de las micotoxinas CIT, y OTA, y los oxidantes MEN, y $\mathrm{H}_{2} \mathrm{O}_{2}$.

\subsection{Respuesta diferencial de transportadores multidroga a las micotoxinas CIT y OTA.}

En primer lugar, sometimos las cepas con los reporteros luciferasa PDR5-, PDR15-, SNQ2-, y YOR1-lucCP ${ }^{+}$a un rango de concentraciones de CIT y OTA y cuantificamos sus perfiles dosis-respuesta en luminómetro. Como en los experimentos luciferasa del capítulo anterior, los valores obtenidos tras su cuantificación en luminómetro representan la expresión luciferasa cuantificada por su actividad y medida como unidades de luz relativas, y fueron normalizados por la OD correspondiente (Figura 20). Para poder comparar más fácilmente los cuatro reporteros representamos la actividad máxima (Amax) para cada concentración (Figura 21). 

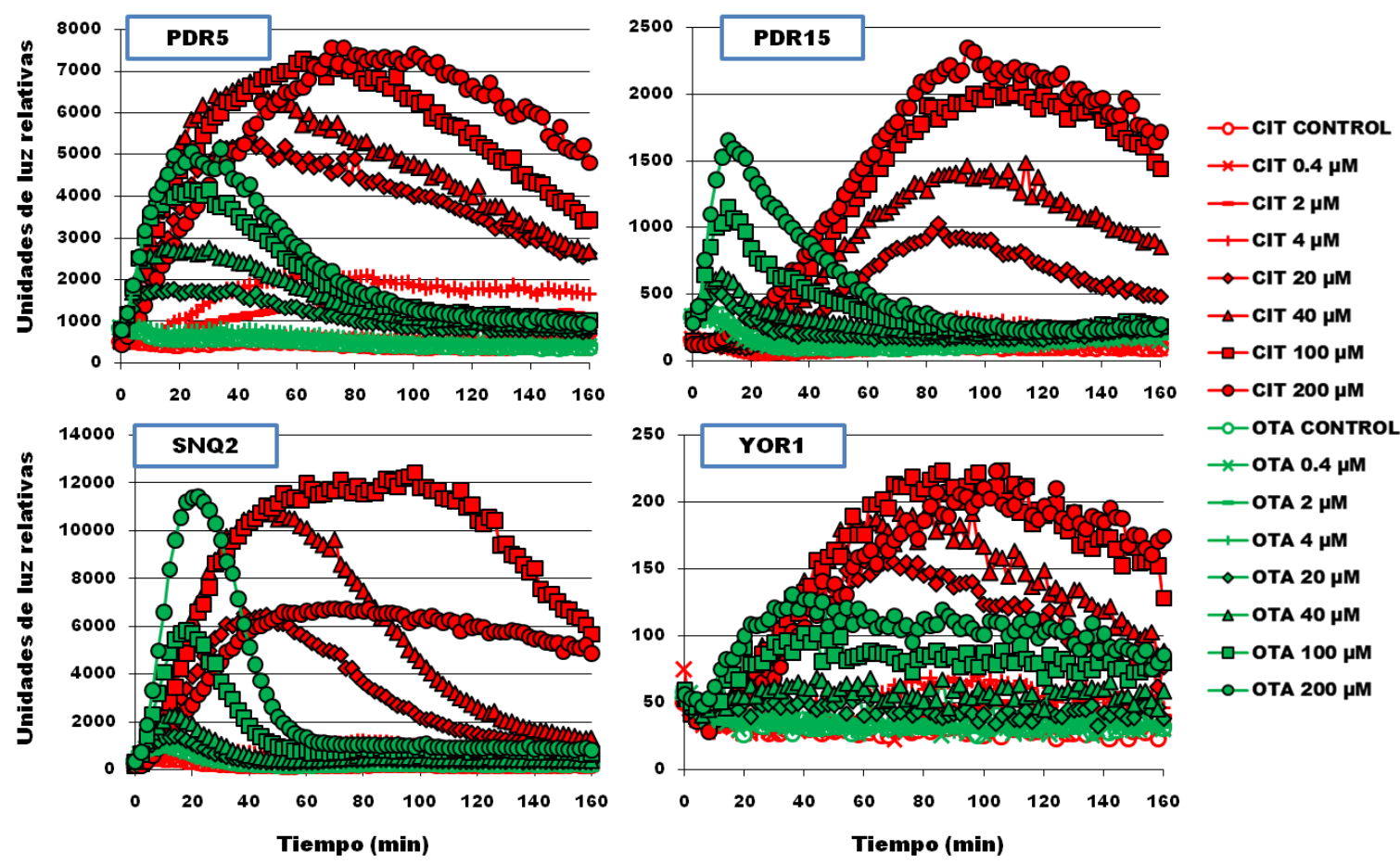

-O-OTA CONTROL

* OTA $0.4 \mu \mathrm{M}$

- OTA $2 \mu \mathrm{M}$

- ОТА $4 \mu \mathrm{M}$

$\rightarrow$ OTA $20 \mu \mathrm{M}$

$\triangle$ OTA $40 \mu \mathrm{M}$

- -ОTА $100 \mu \mathrm{M}$

-O-OTA $200 \mu \mathrm{M}$

Figura 20. Pdr5, Pdr15, Snq2 y Yor1 responden de forma diferencial a las micotoxinas CIT y OTA. Las células de la cepa silvestre BY4741 con las construcciones PDR5-, PDR15-, SNQ2- y YOR1-lucCP ${ }^{+}$se sometieron a un rango de concentraciones $(0,0.4,2,4,20,40,100$ y $200 \mu \mathrm{M})$ de citrinina y ocratoxina A, y se cuantificaron sus perfiles dosis-respuesta de la actividad luciferasa con luminómetro por triplicado. Desviación estándar del ensayo no supera el $15 \%$

En la Figura 20 se observan distintos perfiles de respuesta no sólo entre los distintos transportadores, sino también en función de la droga y dosis. Estos resultados indicarían que los cuatro transportadores participarían en la detoxificación de citrinina y ocratoxina A, aunque de forma diferencial. La primera diferencia se observa entre las mismas drogas, con una respuesta inicial más rápida y transitoria para OTA con respecto a CIT, que muestra curvas más amplias en el tiempo, además de niveles de actividad luciferasa más elevados en general. Este retraso en la inducción ante CIT es más notable en el transportador Pdr15, lo que podría significar que tuviera una función de detoxificación de CIT secundaria con respecto al resto de transportadores. Además, como observamos en las Figuras 20 y 21, los transportadores Snq2 y Pdr5 serían los más activos al someter las células a estas micotoxinas, especialmente Snq2, con niveles de expresión luciferasa más elevados y que al ser tratado con CIT presenta saturación alrededor de una concentración de $100 \mu \mathrm{M}$. Por el contrario, Yor1 sería el que menos responde a estas toxinas. 


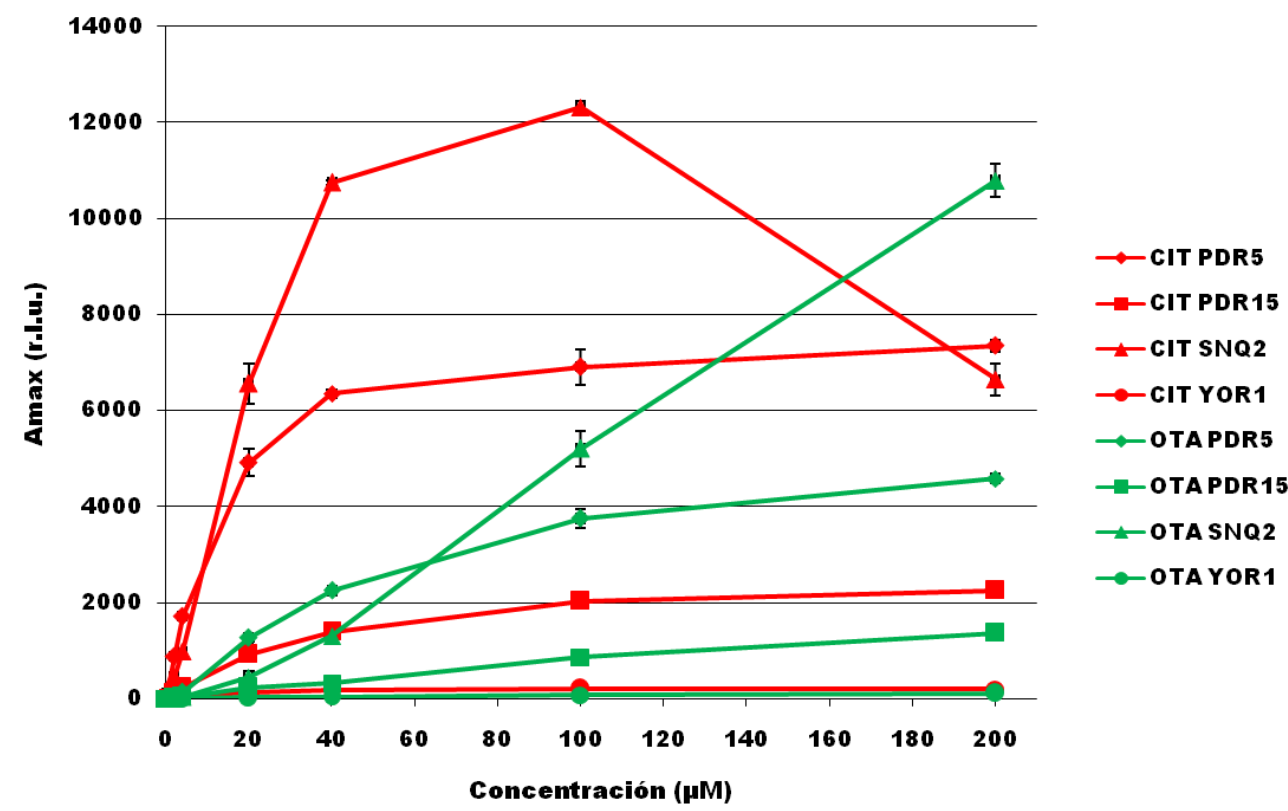

Figura 21. Comparación de la activación de PDR5, PDR15, SNQ2 y YOR1 por CIT y OTA. Representación de la Amax de los reporteros PDR5-, PDR15-, SNQ2- y YOR1-lucCP ${ }^{+}$tratados con un rango de concentraciones $(0,0.4,2$, $4,20,40,100$ y $200 \mu \mathrm{M}$ ) de citrinina (rojo) y ocratoxina A (verde), y se cuantificó la actividad luciferasa con luminómetro por triplicado. Los valores máximos de actividad se representan frente a la concentración de micotoxina.

Estos resultados se corresponderían en gran parte con los obtenidos en el análisis transcriptómico del capítulo anterior, donde Snq2 es el transportador con niveles de inducción más elevados de los tres, y está presente en ambos tratamientos, y por otra parte, YORl aparece sólo en el tratamiento con citrinina y con la menor inducción de los tres.

\subsection{Respuesta diferencial de transportadores multidroga a menadiona y $\mathrm{H}_{2} \mathrm{O}_{2}$.}

Tras estudiar los transportadores Pdr5, Pdr15, Snq2 y Yor1 al ser sometidos a citrinina y ocratoxina A, quisimos conocer la posible actividad de estos transportadores frente a otros compuestos, como menadiona y peróxido de oxígeno, dos moléculas ligadas a estrés oxidativo. Para ello, de nuevo, sometimos las células de levadura con los mismos reporteros integrativos a un rango de concentraciones de $\mathrm{MEN}$ y $\mathrm{H}_{2} \mathrm{O}_{2}$ y cuantificamos la actividad luciferasa en luminómetro (Figura 22). 

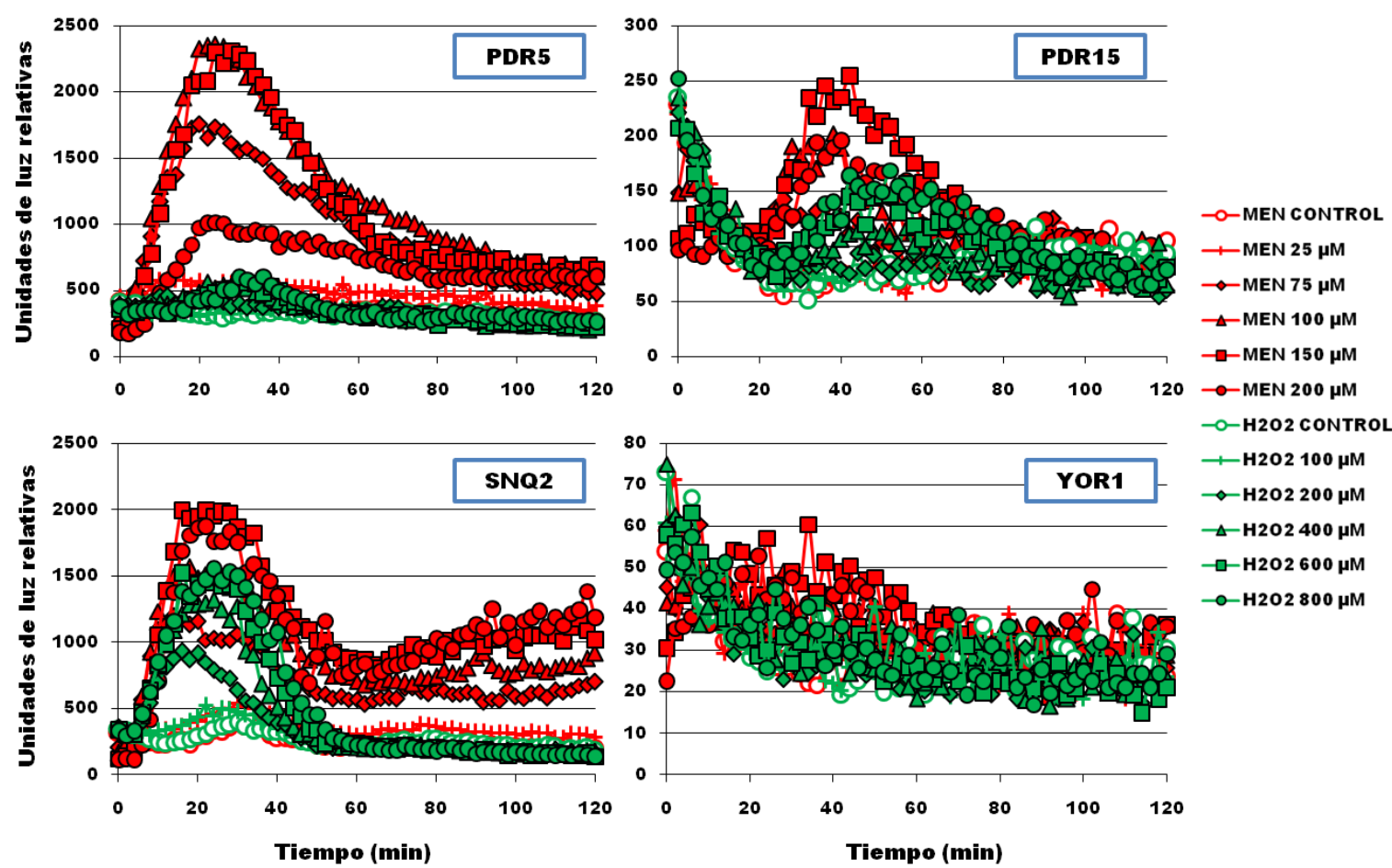

Figura 22. Pdr5, Pdr15, Snq2 y Yor1 responden de forma diferencial a menadiona y $\mathrm{H}_{2} \mathrm{O}_{2}$. Las células de la cepa silvestre BY4741 con las construcciones PDR5-, PDR15-, SNQ2- y YOR1-lucCP+ se sometieron a un rango de concentraciones de menadiona $(0,25,75,100,150$ y $200 \mu \mathrm{M})$ y peróxido de hidrógeno $(0,100,200,400,600$ y 800 $\mu \mathrm{M}$ ), y se cuantificaron sus perfiles dosis-respuesta de la actividad luciferasa con luminómetro por triplicado. Desviación estándar del ensayo no supera el 15\%

Los perfiles dosis-respuesta mostraron diferencias entre los transportadores. Pdr15 mostró una inducción mínima, mientras que Yor1 parece no reaccionar a ninguno de los compuestos. Por el contrario, tanto Pdr5 como Snq2 vuelven a mostrar actividad, aunque en mucha menor medida que frente a CIT y OTA. En el caso de Snq2, este transportador muestra una actividad ligeramente mayor en MEN, pero los perfiles para ambos compuestos es similar. En cuanto a Pdr5, este transportador muestra diferencias claras entre MEN y $\mathrm{H}_{2} \mathrm{O}_{2}$, observando inducción frente a menadiona, pero mucha menor actividad con peróxido de hidrogeno. Para observar más claramente las diferencias entre los distintos transportadores volvimos a representar la actividad máxima de las curvas frente a las concentraciones (Figura 23). 

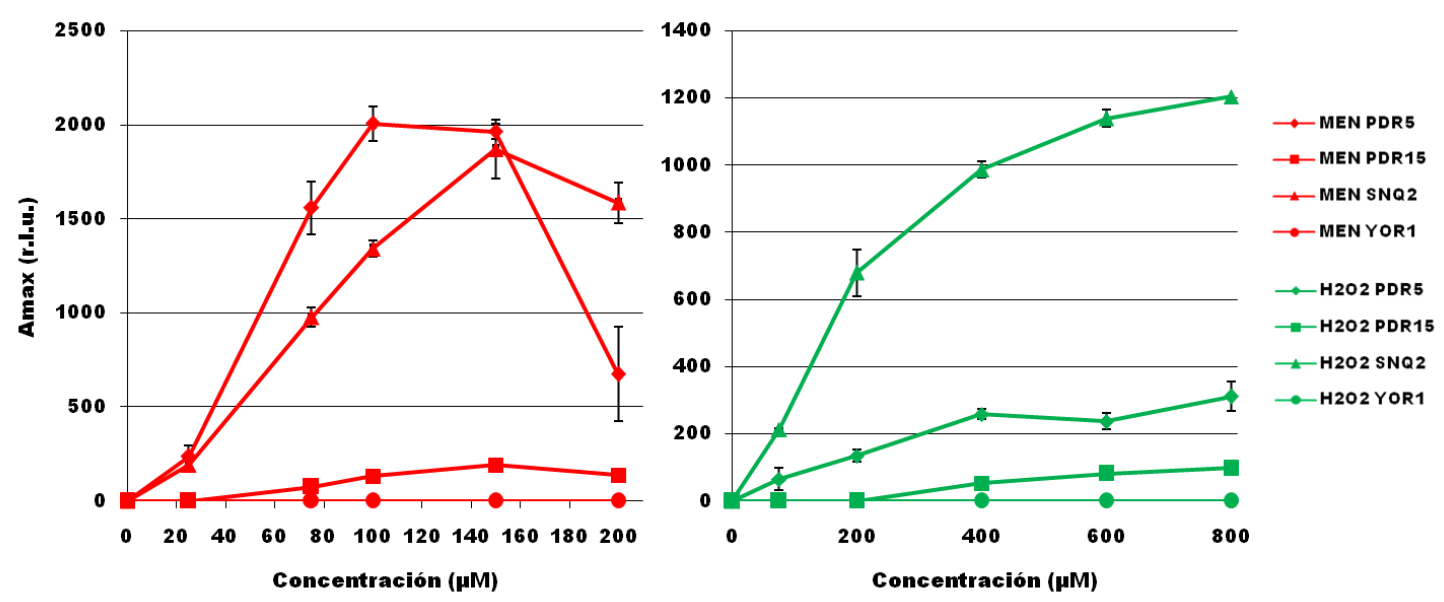

Figura 23. Actividad máxima (Amax) de los reporteros PDR5-, PDR15-, SNQ2- y YOR1-lucCP+. Representación de la Amax de los reporteros PDR5-, PDR15-, SNQ2- y YOR1-lucCP+ tratados con un rango de concentraciones de menadiona $(0,25,75,100,150$ y $200 \mu \mathrm{M})$ (rojo) y peróxido de hidrógeno $(0,100,200,400,600$ y $800 \mu \mathrm{M})$ (verde), y se cuantificó la actividad luciferasa con luminómetro por triplicado. Los valores máximos de actividad se representan frente a la concentración de micotoxina.

Pdr5 y Snq2 vuelven a aparecer como los transportadores más activos de los cuatro, aunque en este caso, además, Snq2 sobresale del resto al ser el único que se induce de forma significante en el tratamiento con peróxido de hidrógeno. Esta respuesta podría estar relacionada con la regulación de Snq2 por parte del factor de transcripción Stb5, implicado en la respuesta a estrés oxidativo (Akache and Turcotte, 2002).

\section{Función de los activadores Pdr1 y Pdr3 en la regulación transcripcional de transportadores multidroga por CIT.}

Tras estudiar los transportadores anteriores en cepas silvestres, quisimos conocer la respuesta de estos mismos transportadores, a excepción de Yor1 por su leve inducción, en cepas defectuosas para los reguladores principales en la respuesta multidroga, $\Delta p d r 1$ y $\Delta p d r 3$, y así tratar de estudiar en más profundidad la posible función diferencial de estos activadores transcripcionales en la respuesta a citrinina. Los resultados de actividad luciferasa en unidades relativas de luz fueron tratados dividiendo cada uno de los puntos por su valor inicial, obteniendo los valores de inducción (Fold Induction) para cada tratamiento y cepa (Figura 24). De esta forma, pudimos comparar y analizar mejor las diferencias entre las cepas y transportadores. 

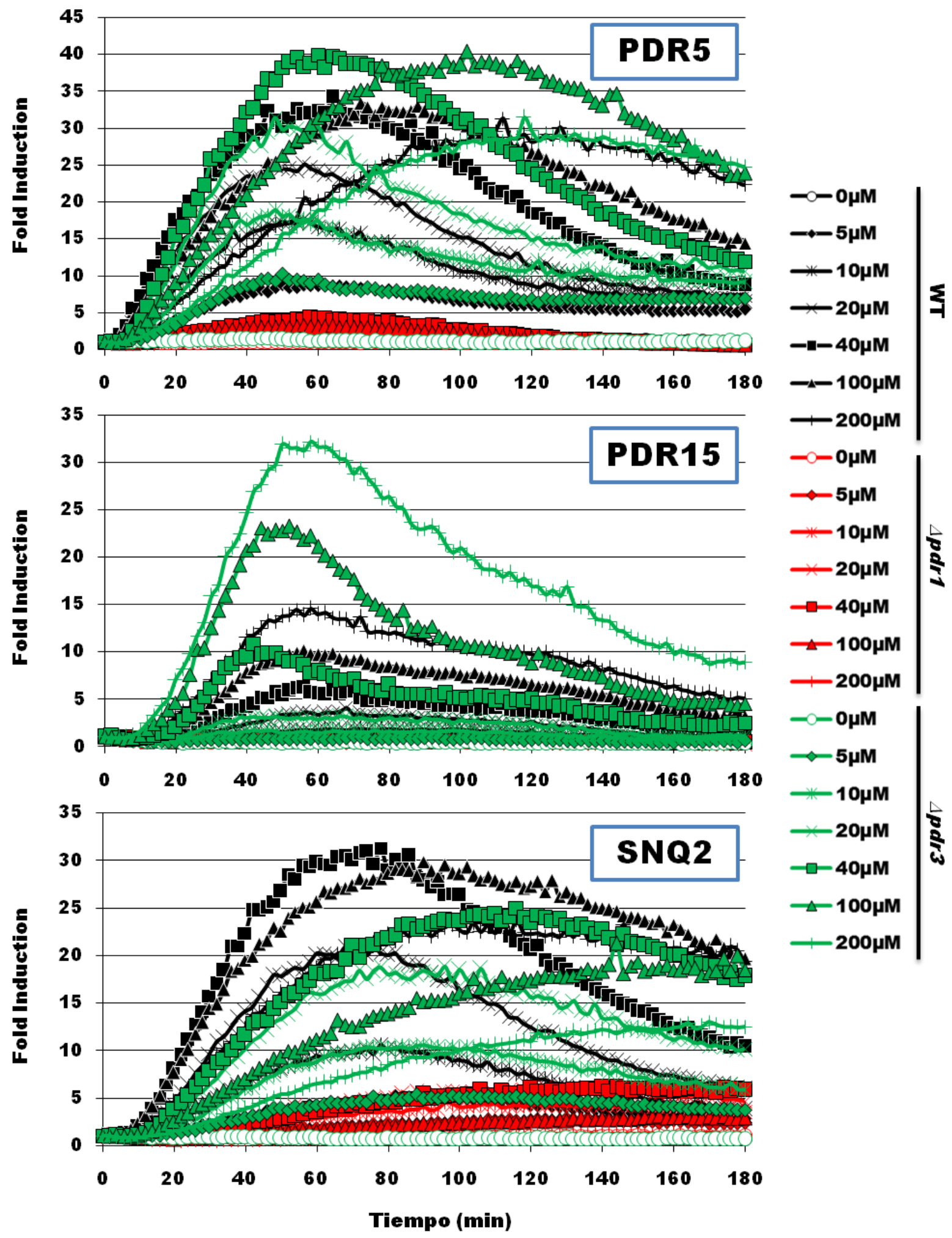

Figura 24. Función de Pdr1 y Pdr3 en la activación de Pdr5, Pdr15 y Snq2 por CIT. Las células de wild type (WT), $\Delta p d r 1$ y $\Delta p d r 3$ con las construcciones PDR5-, PDR15-, y SNQ2-lucCP ${ }^{+}$se sometieron a un rango de concentraciones de citrinina $(0,5,10,20,40,100$ y $200 \mu \mathrm{M})$ y se cuantificó la actividad luciferasa con luminómetro por triplicado. Los resultados se muestran en niveles de inducción (Fold induction). 
En todos los transportadores estudiados se observó un defecto importante en la inducción por CIT en ausencia de la función de Pdr1. En el caso de los mutantes $\Delta p d r 3$ se observaron ligeras diferencias entre transportadores. En la cepa con el reportero $\mathrm{SNQ}^{2}-\mathrm{lucCP}^{+}$hay retraso y menor inducción comparado con la cepa silvestre, mientras que en los otros dos reporteros estudiados la respuesta es mayor en el mutante, más discreta en el caso de PDR5-lucCP ${ }^{+}$, pero evidente en PDR15-lucCP ${ }^{+}$. En la Figura 25 se representan las inducciones máximas de las curvas frente a las distintas concentraciones de citrinina para ver mejor estas diferencias.
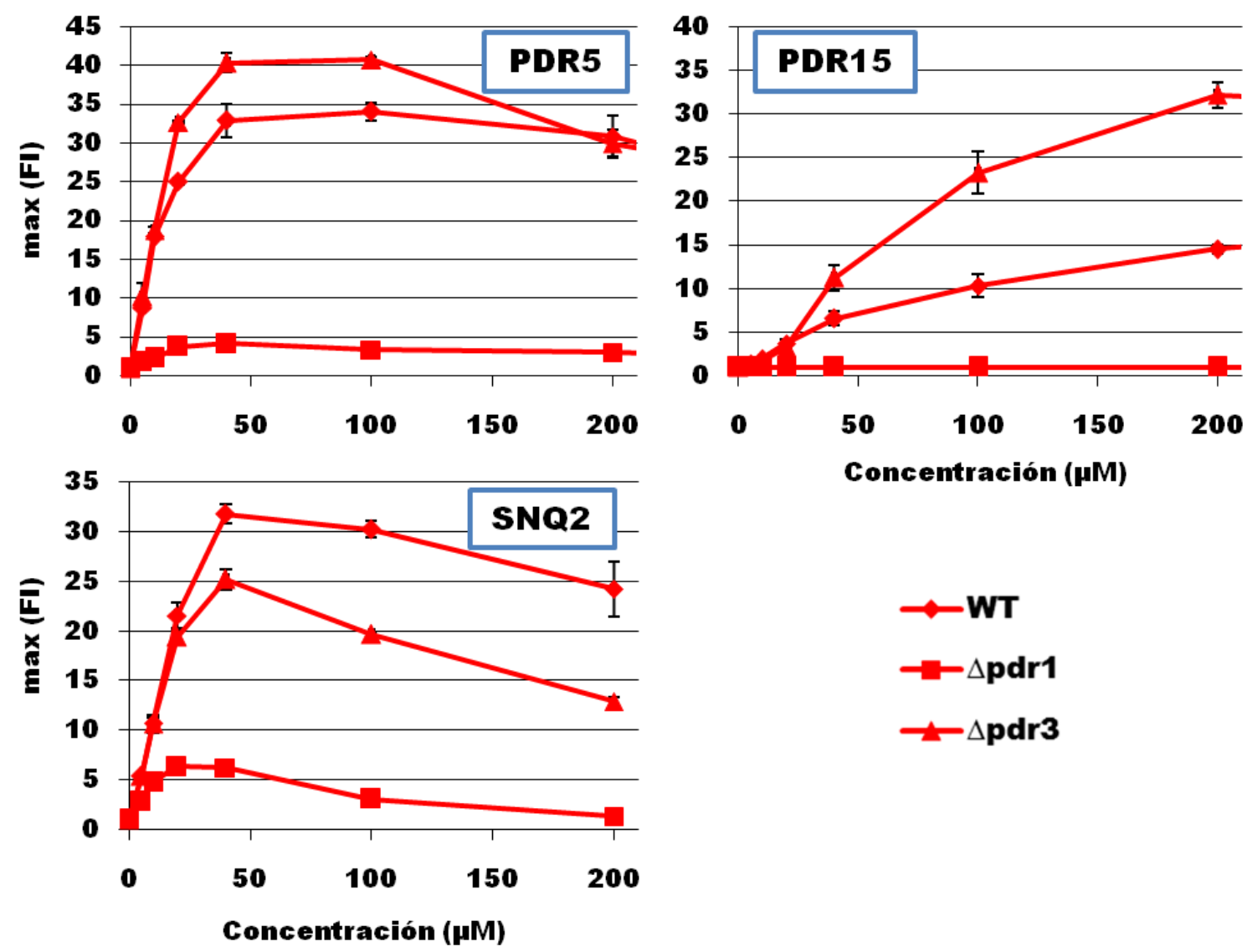

Figura 25. Comparación de las funciones de Pdr1 y Pdr3 en la activación de transportadores multidroga por CIT. Representación de los valores máximos de inducción de los reporteros PDR5-, PDR15-, y SNQ2-lucCP+ en las células de wild type (WT), $\Delta p d r 1$ y $\Delta p d r 3$ tratados con a un rango de concentraciones de citrinina $(0,5,10,20,40,100$ y $200 \mu \mathrm{M})$ y cuantificando la actividad luciferasa con luminómetro por triplicado. Los resultados se muestran en niveles de inducción (Fold induction). Los valores máximos de inducción (FI) se representan frente a la concentración de micotoxina.

Los resultados parecen mostrar que Pdr1 es el principal factor implicado en la regulación de estos transportadores multidroga durante la adaptación celular a citrinina al no observarse apenas inducción cuando éste no está presente. Por el contrario, Pdr3 parece no estar tan involucrado en esta respuesta adaptativa, y además lo hace de forma dispar en función del transportador. Esto podría indicar que su participación en la regulación de estos transportadores fuera secundaria o incluso que actuara como un regulador negativo en los casos de $P D R 5 \mathrm{y}$, especialmente, $P D R 15$, y como ayudante en la activación de $S N Q 2$. 
Además, en la Figura 25 podemos apreciar diferencias en la sensibilidad y capacidad de saturación de los transportadores, en este caso, independiente de la cepa. Snq2 parece ser el transportador que antes se satura, alcanzando su máximo a una concentración de citrinina de $40 \mu \mathrm{M}$, mientras que en Pdr5 estaría a $100 \mu \mathrm{M}$, y en el caso de Pdr15, llega a una concentración de $\geq 200 \mu \mathrm{M}$. Si nos centramos en la cepa silvestre, parece que, como ya se observó en anteriores experimentos, Pdr5 y Snq2 serían los transportadores principales frente a citrinina, mientras que Pdr15, con unos niveles de inducción menores y menor sensibilidad, podría actuar como un transportador secundario.

A continuación, quisimos profundizar más en la posible implicación de varios reguladores Pdr, no sólo de Pdr1 y Pdr3, en la respuesta de adaptación celular a citrinina y ocratoxina A.

\section{Estudio de los factores de transcripción Pdr en la respuesta adaptativa celular a micotoxinas y otros compuestos.}

Los transportadores multidroga están regulados por distintos factores de transcripción. De ellos, Pdr1 y Pdr3, son considerados los mayores reguladores, especialmente Pdr1. En el apartado anterior, comprobamos que éste era el caso al someter las células a varias concentraciones de citrinina.

Aunque Pdr1 es el factor de transcripción principal de los reguladores Pdr conocidos en levadura, no es el único. Además, se ha visto que en muchas ocasiones estos factores reguladores trabajan conjuntamente, e incluso se regulan entre ellos (Mamnun et al., 2002; Akache and Turcotte, 2002). En este trabajo, junto con Pdr1 y Pdr3, nos centramos en estudiar los factores de transcripción Pdr8, Yrm1, Yrr1, y Stb5. Estos factores de transcripción regulan la actividad de los transportadores multidroga reconociendo secuencias denominadas PDRE que se encuentran en los promotores de los genes codificantes de las proteínas diana.

\subsection{Respuesta adaptativa a citrinina y ocratoxina A a través de los elementos} PDRE.

En primer lugar, estudiamos qué factores de transcripción respondían a CIT y OTA por medio de la activación de los elementos PDRE. Para ello se emplearon, junto con la cepa silvestre, cepas de levadura defectuosas para dichos factores ( $\Delta p d r 1, \Delta p d r 3$, $\Delta p d r 8, \Delta y r m 1, \Delta y r r l)$ que portaban las construcciones $3 x$ PDRE-lucCP ${ }^{+}$. Sometimos estas células a un rango de concentraciones de citrinina y ocratoxina $\mathrm{A}$, y cuantificamos sus respuestas de activación dependientes de dosis con el luminómetro (Figura 26). 

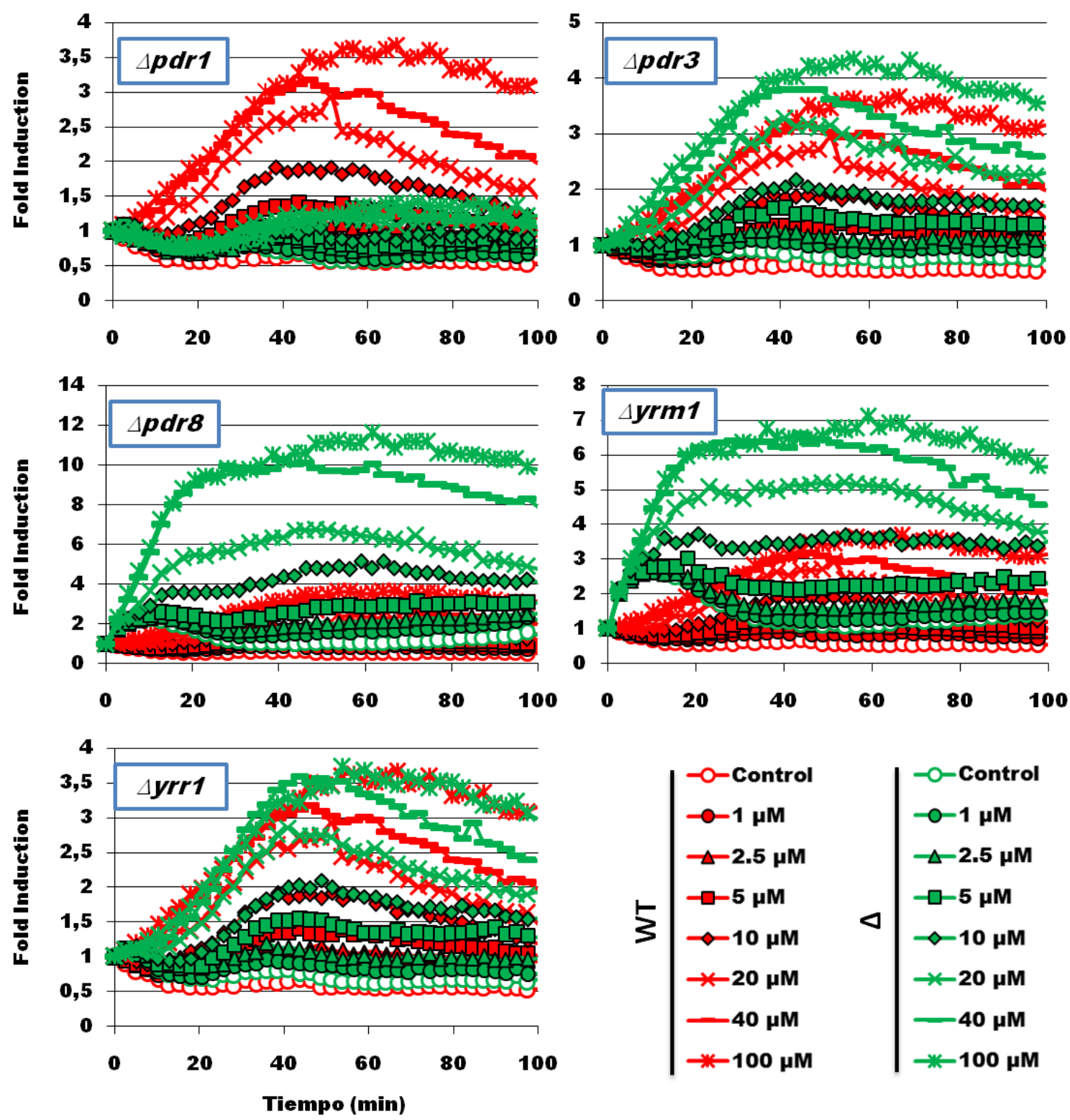

Figura 26. Función de los activadores transcripcionales Pdr en la regulación génica a través de elementos PDRE por CIT. Las células de wild type (WT), $\Delta p d r 1, \Delta p d r 3, \Delta p d r 8, \Delta y r m 1$ y $4 y r r 1$ con el reportero 3xPDRElucCP ${ }^{+}$se sometieron a un rango de concentraciones de citrinina $(0,1,2.5,5,10,20,40$, y $100 \mu \mathrm{M})$ y se cuantificaron sus perfiles dosis-respuesta de la actividad luciferasa con luminómetro por triplicado. Los resultados se muestran en niveles de inducción (Fold induction).

En la Figura 26 se representan los perfiles dosis-respuesta a varias concentraciones de citrinina en cada uno de los mutantes (verde) con respecto a la cepa silvestre (rojo). Como se observó anteriormente en el caso de la regulación de los transportadores, de nuevo, las células de mutantes defectuosos para el factor de transcripción Pdr1, no muestran actividad. Esta inactividad en el mutante $\Delta p d r l$ también se observó en el tratamiento con OTA (Figura 27), lo que podría indicar el papel fundamental de Pdr1. Por el contrario, $\Delta p d r 8$ e $\Delta y r m 1$, en tratamientos con CIT presentaron mayores niveles de inducción que la cepa silvestre, aunque no mostraron grandes diferencias cuando se trataron con OTA. 

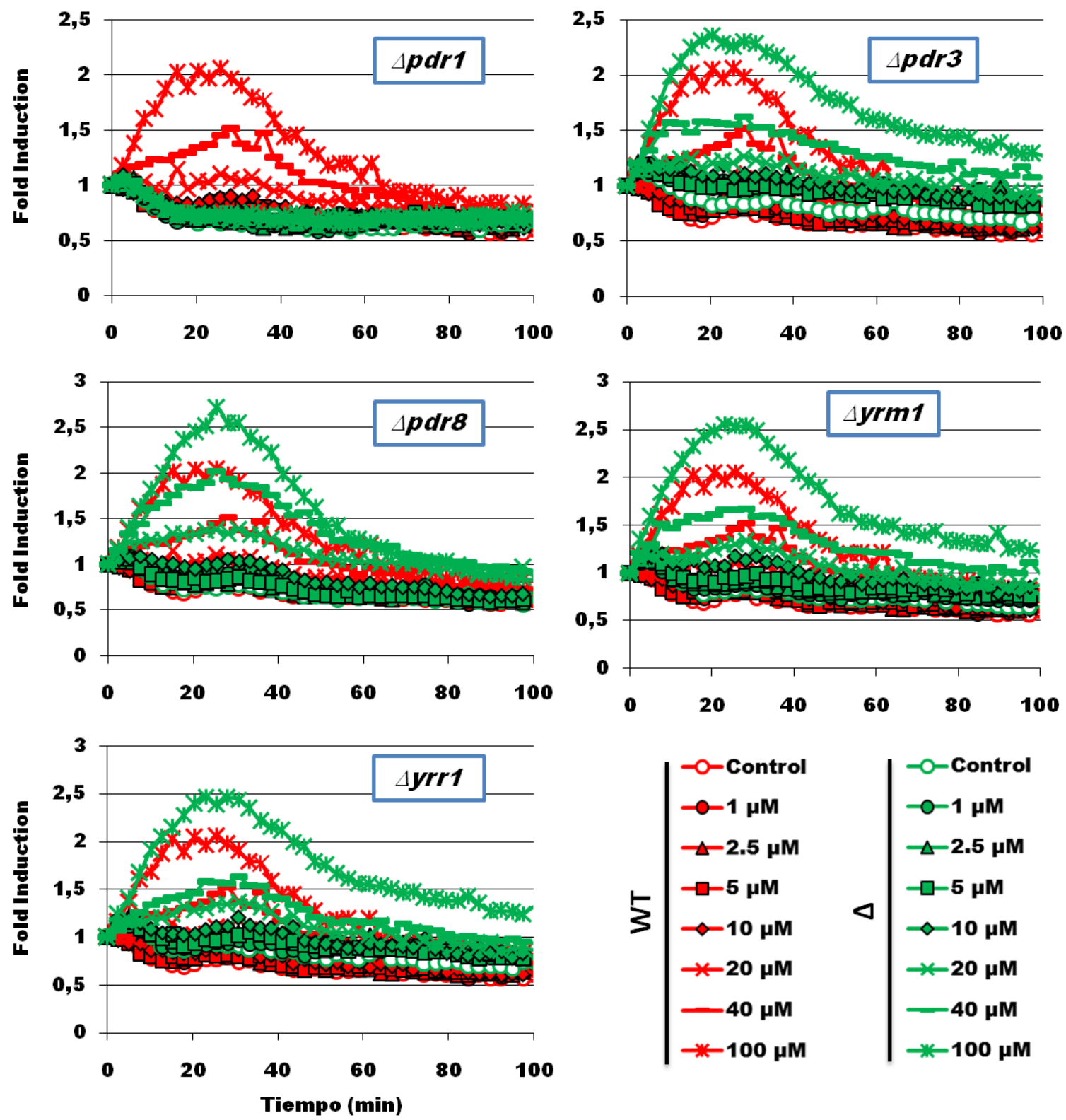

Figura 27. Función de los activadores transcripcionales Pdr en la regulación génica a través de elementos PDRE por OTA. Las células de wild type (WT), $\Delta p d r 1, \Delta p d r 3, \Delta p d r 8, \Delta y r m 1$ y $\Delta y r r 1$ con el reportero 3xPDRE-lucCP+ se sometieron a un rango de concentraciones de ocratoxina A $(0,1,2.5,5,10,20,40$, y $100 \mu \mathrm{M})$ y se cuantificaron sus perfiles dosis-respuesta de la actividad luciferasa con luminómetro por triplicado. Los resultados se muestran en niveles de inducción (Fold induction).

Para estudiar y poder comparar más fácilmente ambas condiciones en los distintos mutantes, representamos los valores máximos de inducción frente a las concentraciones (Figura 28). 


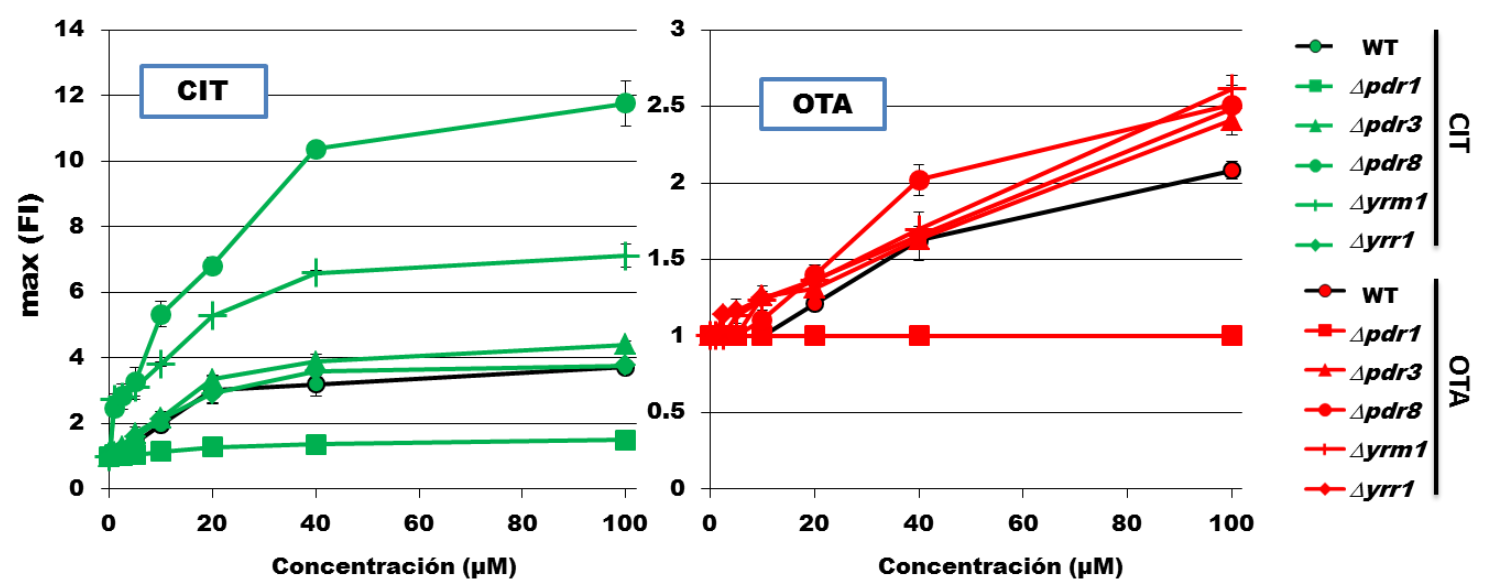

Figura 28. Comparación de las funciones de Pdr1, Pdr3, Pdr8, Yrm1, e Yrr1 en la activación génica a través de PDRE por CIT y OTA. Representación de los valores máximos de inducción del reportero 3xPDRE-lucCP ${ }^{+}$en las células de wild type (WT), $\Delta p d r 1, \Delta p d r 3, \Delta p d r 8, \Delta y r m 1$ y $4 y r r l$ tratados con un rango de concentraciones de citrinina y ocratoxina A $(0,1,2.5,5,10,20,40$, y $100 \mu \mathrm{M})$ y cuantificando la actividad luciferasa con luminómetro por triplicado. Los resultados se muestran en niveles de inducción (Fold induction). Los valores máximos de inducción (FI) se representan frente a la concentración de micotoxina.

Los resultados parecen mostrar que Pdr1 es el principal regulador, a través de los elementos PDRE entre estos factores en la respuesta adaptativa a citrinina y ocratoxina A, al no observarse actividad en el mutante defectuoso para Pdr1 cuando es tratado con ambas micotoxinas. Por otro lado, también se observó que tanto $\Delta p d r 8$ como $\Delta y r m 1$ presentaban mayor inducción con respecto a la cepa silvestre en el tratamiento con CIT, pudiendo implicar que Pdr8 e Yrm1 tengan algún tipo de papel como reguladores negativos en la respuesta de adaptación a esta toxina a través de los elementos PDRE. Por su parte, ni Pdr3, ni Yrr1, parecen tener un efecto importante en la adaptación celular a CIT y OTA a través de los elementos PDRE en levadura.

\section{Reconocimiento de xenobióticos por parte de los factores de transcripción Pdr.}

Hasta ahora hemos visto que, por un lado, los transportadores estudiados, Pdr5, Pdr15, Snq2 y Yor1, responden con sensibilidad diferente a distintos compuestos químicos, y por otro lado, que la eliminación de los factores de transcripción Pdr1, Pdr3, Pdr8, Yrm1, e Yrr1, tiene efectos diferenciales en la activación a través de los PDRE en respuesta a las micotoxinas CIT y OTA. Por lo tanto, para estudiar en mayor profundidad la posibilidad de que los factores de transcripción Pdr reconocen sustratos de forma diferencial, desarrollamos un sistema experimental que nos permitiera investigar la interacción/activación de estos factores individualmente.

Para ello, empleamos una modificación del sistema luciferasa general. Las células

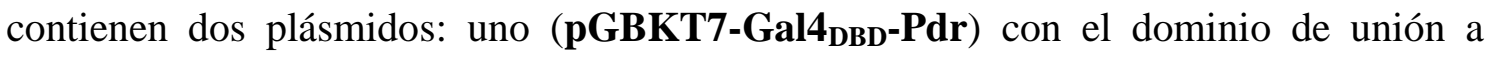
ADN (DBD) de Gal4 fusionado al dominio de unión a ligando (LBD) de factores de transcripción Pdr concretos (Pdr1, Pdr3, Pdr8, Yrm1, Yrr1, y Stb5), y otro plásmido (pAG413-GAL1 UAS-lucCP $^{+}$) con las secuencias de activación UAS de GAL1 (a la que se une el DBD Gal4) fusionado al gen de luciferasa desestabilizada. De esta forma, si hay reconocimiento por parte del factor de transcripción, podemos cuantificarlo con la 
actividad luciferasa. En la Figura 29 se muestra una representación del funcionamiento de este sistema experimental.
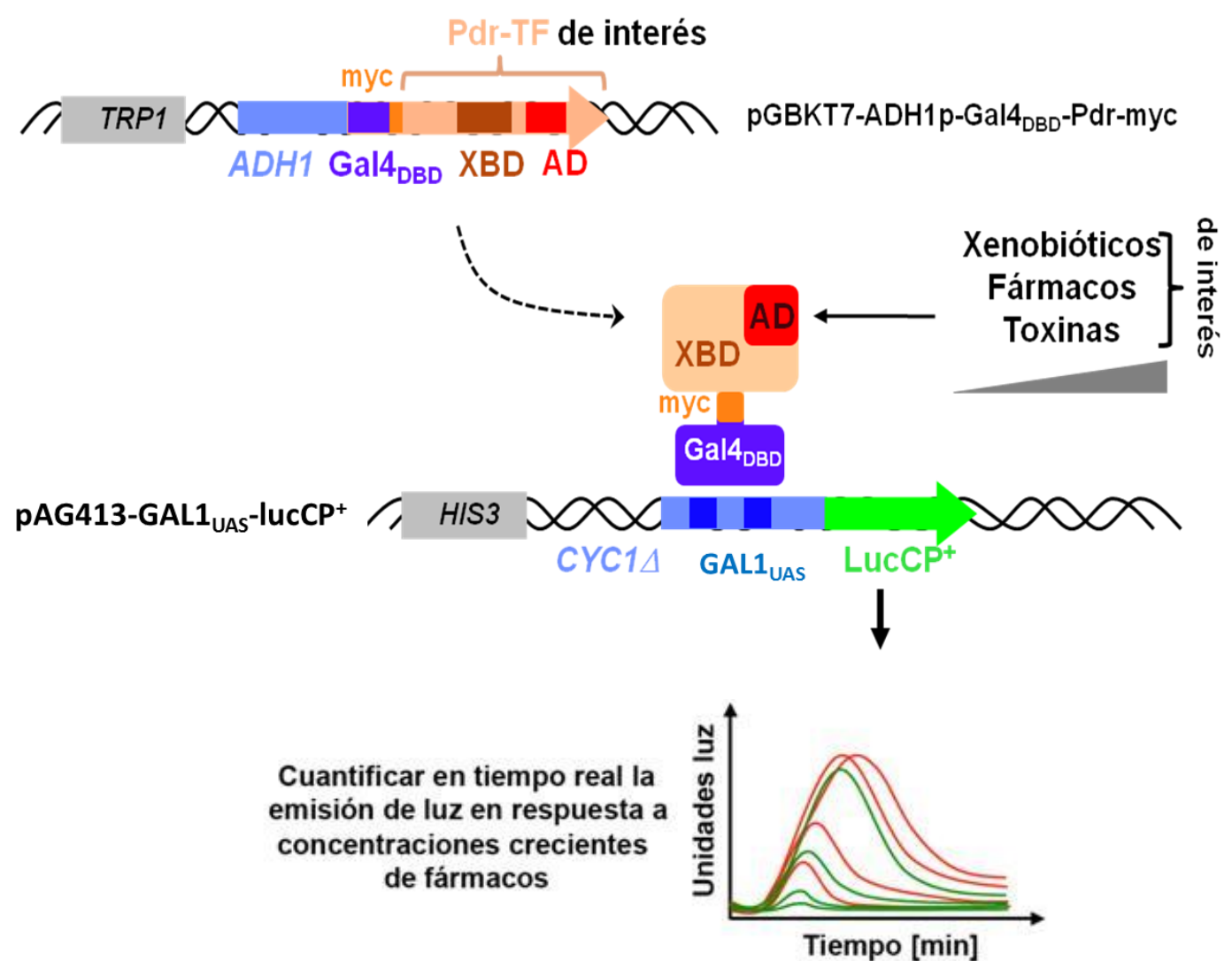

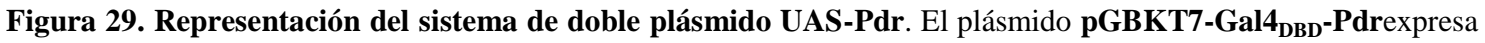
de forma constitutiva proteínas con el dominio de unión a ADN (DBD) de Gal4 fusionado al dominio de unión a ligando (LBD) de los factores Pdr, representado aquí con el dominio de unión a xenobióticos (XBD) y el dominio de activación (AD). El plásmido pAG413-GAL1 UAS $^{- \text {lucCP}^{+}}$contiene las secuencias de activación UAS de GAL1 fusionadas al gen de luciferasa desestabilizada $\left(\operatorname{lucCP}^{+}\right)$. Las proteínas fusión $\mathrm{GAL}_{\mathrm{DBD}}-\mathrm{Pdr}_{\mathrm{LBD}}$ reconocen las secuencias UAS de GAL1 $\mathrm{UAS}^{-} \mathrm{lucCP}^{+}$. Cuando los compuestos xenobióticos entran en la célula y son reconocidos por el dominio $\mathrm{Pdr}_{\mathrm{LBD}}$ se produce la activación, y se observa actividad luciferasa, cuantificándola en luminómetro.

Para comprobar la expresión de las proteínas fusión $\mathrm{Gal}_{\mathrm{DBD}}-\mathrm{Pdr}_{\mathrm{LBD}}$ codificadas por el

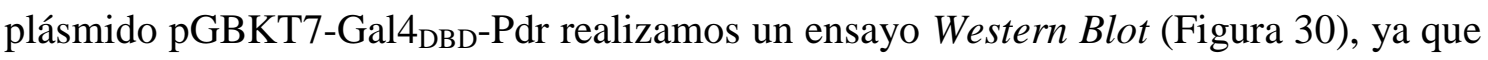
este plásmido contiene un epítopo c-myc que permitía detectar la proteína con un ensayo de inmunoprecipitación. En este experimento se emplearon cepas de levadura con fondo genético W303-1A con el gen GAL4 delecionado (Agal4) para aumentar la actividad luciferasa evitando que la proteína endógena Gal4 compita con nuestra proteína de fusión. Estas células de levadura fueron transformadas con los plásmidos pGBKT7-Gal4 ${ }_{\mathrm{DBD}}-\mathrm{Pdr}$ y se verificó que la expresión de nuestras proteínas era correcta en todos los casos. 


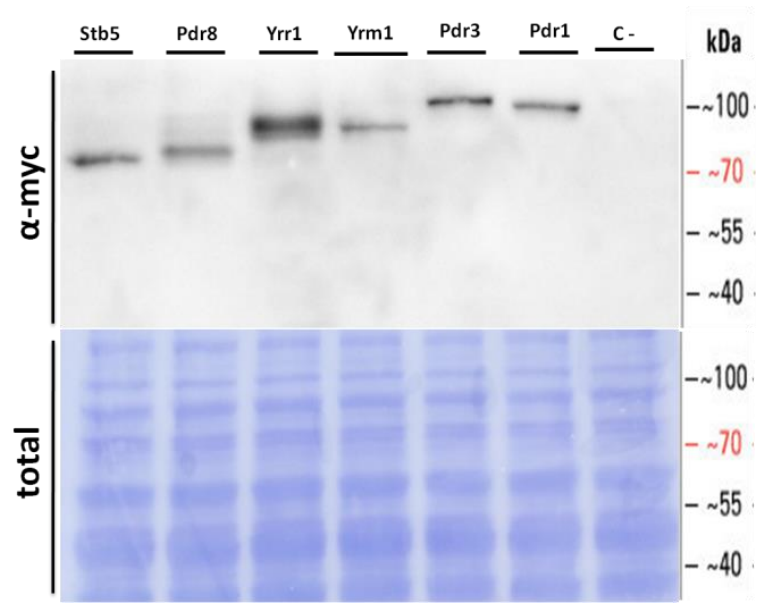

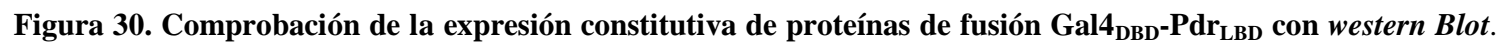
Se utilizó la cepa de levadura $\Delta$ gal4 expresando con la proteína fusión del factor de transcripción Pdr indicado. Se detectaron las proteínas mediante western blot con anticuerpo monoclonal anti-myc $(\alpha$-myc) y se comparó con la respectiva carga total de proteínas (total).

\subsection{Análisis bioinformático.}

En primer lugar quisimos estudiar a nivel de secuencia proteica la relación entre los factores de transcripción Pdr de la familia GAL4 que participan en la respuesta multidroga (Pdr1, Pdr3, Pdr8, Yrm1, Yrr1, y Stb5). Se conoce que esta familia de factores de transcripción contiene un cluster de Zinc del tipo $\mathrm{Zn}_{2} \mathrm{Cys}_{6}$ de unión a ADN (DBD) que se encuentra conservado (Kolaczkowska and Goffeau, 1999), pero apenas hay información sobre la similitud entre dominios de reconocimiento de los xenobióticos (XBD). A pesar de ello, la mayoría de estudios y revisiones sugieren que estos dominios pueden variar y estar menos conservados entre los factores de transcripción, de forma que se aumente la especificidad y el número de compuestos reconocidos.

En primer lugar, se realizó un alineamiento entre las secuencias proteicas de los factores de transcripción más estudiados, Pdr1 y Pdr3. Para ello se empleó la herramienta Blast para proteínas de la página web del National Center for Biotechnology Information (NCBI) y se obtuvo un alineamiento con un $34 \%$ de similitud de secuencia. A continuación, quisimos comparar ambos factores a nivel de los dominios descritos. Como hemos dicho anteriormente, el DBD está conservado y descrito, pero no así el XBD. Thakur et al., 2008, realizaron un estudio de estos dos factores en respuesta a azoles, y describieron experimentalmente una región de reconocimiento a estos compuestos. Por ello, decidimos realizar un alineamiento entre las regiones XBD descritas en este estudio para Pdr1 (aa352-543) y Pdr3 (aa290-420) (Figura 31). Además, también comparamos las regiones DBD conservadas de estos factores (Figura 32). El resultado obtenido fue una similitud de secuencia del $37 \%$ en el dominio XBD, mientras que la similitud en la región DBD fue del 69\%. Esto corrobora la suposición de que las regiones XBD no se encuentran muy conservadas para poder permitir la promiscuidad y diferencias de especificidad entre los factores de transcripción. 
Pdr1 362 VALVINHLPOPFVRNITGISNSELLSEMNNDISMFGILLKMLDMHKNSYONFLMEITSNP 421

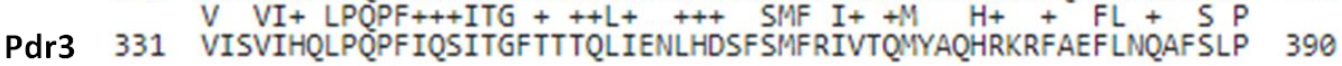

Pdr1 422 SVAKNTQSIDVLQEFIHYCQAGEALIALCYSYYNSTL 458

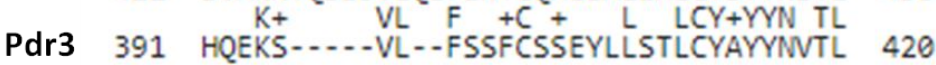

Figura 31. Comparación de la secuencia aminoacídica de la región XBD de Pdr1 y Pdr3. Alineamiento de las secuencias proteicas de la región XBD de Pdr1 (aa352-543) y Pdr3 (aa290-420) con la herramiento Blast del NCBI.

\section{Pdr1 40 SKVSKACDNCRKRKIKCNGKFPCASCEIYSCECTF 74 \\ Pdr3 9 SKVSTACVNCRKRKIKCTGKYPCTNCISYDCTCVF 43}

Figura 32. Comparación de la secuencia aminoacídica de la región DBD de Pdr1 y Pdr3. Alineamiento de las secuencias proteicas de la región DBD de Pdr1 (aa40-77) y Pdr3 (aa9-49) con la herramiento Blast del NCBI.

No hay mucha información detallada sobre los dominios XBD del resto de factores de transcripción implicados en la respuesta multidroga, pero quisimos conocer un poco mejor la relación filogenética entre ellos previamente a su estudio. Para ello, realizamos un alineamiento de secuencia proteica empleando la herramienta web CLUSTALW (Figura 33) y posterior representación del árbol filogenético (Figura 34).

\begin{tabular}{|c|c|c|}
\hline PDR1 & 1 & .....-MRGLTPKNGVHIETGPDTESSADSS-.....-NFSTGFS KIRKPRSIVSKACD \\
\hline PDR3 & 1 & . INKSTRSIVSTACV \\
\hline PDR8 & 1 & . \\
\hline YRM1 & 1 & .............................. MSKRGS-LQORASPSEE-T KKAQKRRR PIKSCA \\
\hline YRR1 & 1 & MKRRSDALLGSF--QATINTPPSDNSNSTAGG-AN-GSNSGTP-TITSGKKRNKLIKSCG \\
\hline STB5 & 1 & 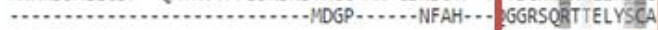 \\
\hline PDR1 & 48 & 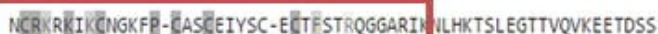 \\
\hline POR3 & 17 & NCRKRKIKGTGKYP-CTMCISYDC-TCVFLKKHLPQKELSSQ--SLPTTAVAPPS-...S \\
\hline PDR8 & 33 & 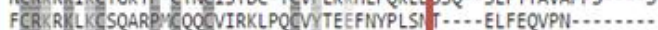 \\
\hline YRM1 & 33 & FCR KRELLCDQQKPYCSTCKTRGRSGCLYTEKFTHKIE -...-ELFGSTPN-... \\
\hline YRR1 & 56 & FCRRRKLRCDOQKPYCSTCISRNLTTCQYAEEFNUKNIEK $\mathrm{K}$....-ATYGPYPN-......... \\
\hline STB5 & 24 & RCRXLKKKCGKQIPTCANCDKNGA-HCSY PGRAPRRTKR LLADAMLRGEYVPVKRNKKVG \\
\hline POR1 & 106 & STSFSNPQRCTDGPCAVE $\cdots \cdots \cdot$ QPTKFF $\cdots \cdots$ ENFKLGGRSSGDNSGSDG - KNDDDDV \\
\hline PDR3 & 69 & HANEASADVOHLDTAIK -.....-LDNOYYFKLLMDLIOTPVSPSATHAPDT - -SNNPTN \\
\hline PDR8 & 81 & 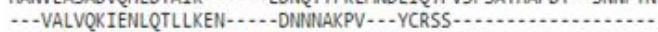 \\
\hline YRM1 & 81 & ...IELLKRTEDLEKRLDDKELTEKDV................ \\
\hline YRR1 & 104 & ...ADLLLKKVEELENKIRTLEAEKNTNSSASSM.... YTSPNFPPLGGSVGRG..... \\
\hline ST85 & 83 & KSPLSTKS -...MP............NSSSPLSAMGAITPGFSPYENDDAHKMKQLKPSD \\
\hline PDR1 & 154 & 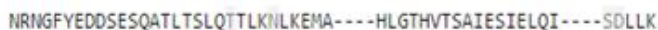 \\
\hline PDR3 & 121 & DWWILFKDOSKYQNQLVTYQUILTILYALP....PCD-DTQLLIDKTKSQL ..... \\
\hline POR8 & 111 & 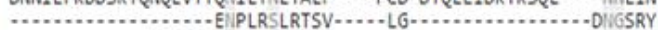 \\
\hline YRM1 & 105 & 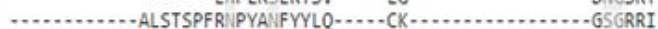 \\
\hline YRR1 & 150 & $\ldots \ldots$ STETSSPLPDGVINPYADRYLL $-\ldots \ldots$ SK $\cdots \ldots \ldots$ \\
\hline \multirow[t]{2}{*}{ STB5 } & 127 & PINLVMGASPNSSEGVSSLISVLTSLNDNSNPSSHLSSNENSMIPSRSLPASVQQSSTTS \\
\hline & & .. \\
\hline PDR1 & 206 & 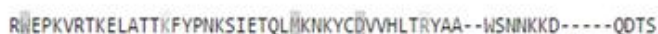 \\
\hline PDR3 & 172 & SWWPEINYPKLSSFSPRPORSIETYLL TMKYRN KIHMTRFSF--WTDQNVKSOSPDSFLA \\
\hline PDR8 & 130 & VFGP......... TSWKTLSLFEONKFOTEFOHLWKVLKPLP..........ECTKSQLN \\
\hline YRM1 & 131 & VYGP..........TSLRTHLSNDDNRFVWTYWOLWSKVKIERNRWKARHKWTMKPETTQLL \\
\hline YRR1 & 181 & LYGP.......... TSMRTQIANSWWGGIEKYKOLLWAKVKVERNIKWKQNNQKTMCRELGLL \\
\hline \multirow[t]{2}{*}{ STB5 } & 187 & 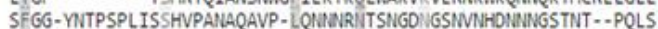 \\
\hline & & $: \quad: \quad$. \\
\hline PDR1 & 259 & SQPLIDE--IFGLYS--PF--OFLSLQGIGKCFONYRSKSKCEIFPRTAKETIYIMLRFF \\
\hline POR3 & 230 & TTPLVDE --VFGLFS -.PI -.PAFSLRGIGYLIKKNIENTGSS-MLIDTKETIYLILRLF \\
\hline PDR8 & 171 & E........... - DVVADLPSFPQMESCIK $\cdots \cdots \cdots \cdots$ \\
\hline YRM1 & 182 & EGPPLEKT-GSDILO - - Q VONVLPSFEQSSKIIT ....... \\
\hline & 232 & DESDW $-=0$-PDPLIK --OICRFLPSYNKALSILD $\ldots \ldots \ldots \ldots$ \\
\hline \multirow[t]{2}{*}{ STB5 } & 243 & LTPYANWSAPNGKFDSVPVDASSIEFETMSCCFKGGRTTSINREDGSFKSIDRSLLDRFI \\
\hline & &. \\
\hline
\end{tabular}




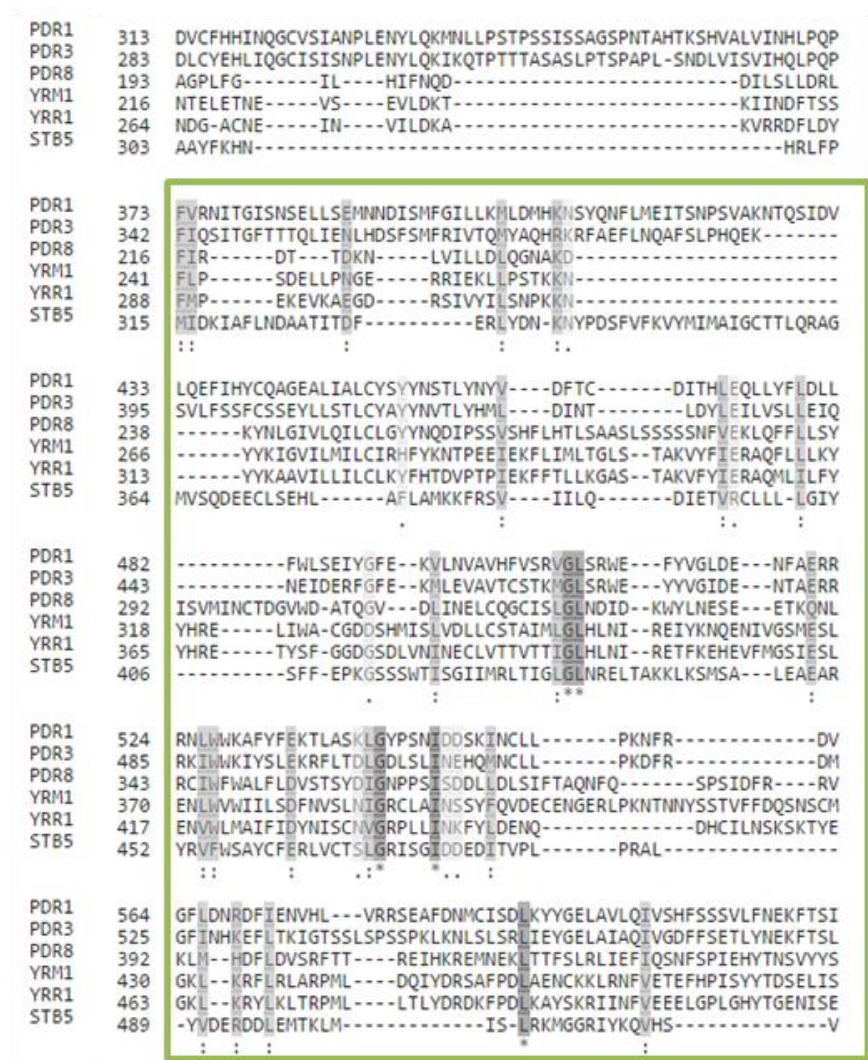

\begin{tabular}{|c|c|c|}
\hline OR1 & 621 & RNTSKPSWVEKKLL-FEVLEIFNETEMKYDAIKEQTGKLFDIAFSKDSTELKVSREDKI \\
\hline PDR3 & 585 & EVSVKPTIIROKLL-EKVFEDIESFRLKLAKIKLHTSRVFQVAHCKYP..-EYPKNDLI \\
\hline PDR8 & 446 & DID $\cdots . .$. PFDILILSRSLSIVASI $\cdots . . . .$. YN $\cdots$ \\
\hline YRM1 & 484 & 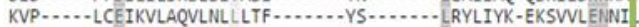 \\
\hline YRR1 & 517 & EVP-..... LRESRILSMAVGLLLSF $\ldots . . . \ldots$ YA $\cdots \ldots \ldots$ IHSVLK-VRNIESKNNT \\
\hline STBS & 520 & 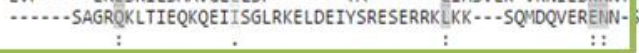 \\
\hline PDR1 & 680 & ASKFV̄LLFYE-HHFCRMVNESDNIVARLCVHRRPSILIENLKIYLHKIYKSWTDMUKÏ-... \\
\hline PDR3 & 641 & AAKFVSYHK -NTWFSILGAVNNLIIARLS - EDPEVITEOSMKYANEMFQEWREIMQF-.. \\
\hline PDR8 & 486 & QFLLISISV..$- \ldots \ldots$ CVNTMVFHFK -........ EPINDOENVLTEGLKLSIILINPLLIR \\
\hline YRM1 & 524 & QTILVSFSL $\cdots . . . .-$ VINTTILCFNLDEKHFPEFFDHVCVHLPPFMALSLVTNFLFPR \\
\hline YRR1 & 557 & QLVLINFSI $\cdots . . . .$. IVNTTIRCYRIDKALYPEKFEASNPHLPPHMALSMSLTAGLFSK \\
\hline \multirow[t]{2}{*}{ STBS } & 570 & TTNISFHSSEIWLAMRYSQLQILLYRPSALMP KPPIDSLSTLGEFCLQAWKHTYTLYKK \\
\hline & & $\therefore$ \\
\hline PDR1 & 736 & ...-NDYSVYRSFAHYSISCIILVSQAFSVAEFIIKVWDVWWIRVFKRF \\
\hline PDR3 & 695 & -..TDFIWWACLDFYELIFFVMASKFYVEDPHITLEDVINTLKVFKRI \\
\hline POR8 & 532 & IVSQV $\cdots \ldots$ \\
\hline YR/1 & 577 & 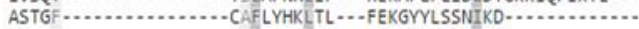 \\
\hline YRR1 & 610 & 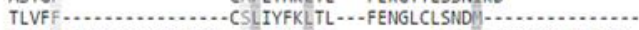 \\
\hline STBS & 630 & 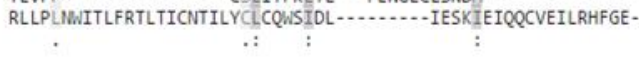 \\
\hline PDR1 & 786 & LDIKIFSENETNEHVFNSQSFKDYTRAFSFLTIVTTRIMMLLAYGESSSTNLDVISKYIDEN \\
\hline PDR3 & 745 & TNIISFFNNNLDEKDYDCQTFREFSRSSSLVAISIRIIFLKYCYAEQIDRAEFIERLKEV \\
\hline POR8 & 570 & 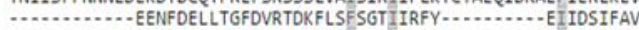 \\
\hline YRM1 & 605 & $\ldots \ldots \ldots \ldots \ldots$ QEVTOWDLSTLNIPLDKAMNLLTAFKIHS $\cdots \ldots \ldots \ldots$ IFAKWSN- \\
\hline YRR1 & 636 & $\ldots \ldots \ldots$ EVGWSDLTKLTVPLDKDLSLGTAMSLYS $\ldots . \ldots \ldots \ldots$ SIFDRLFT- \\
\hline STB5 & 680 & 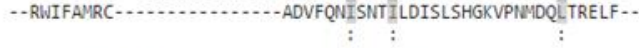 \\
\hline PDR1 & 846 & APDLKGIIELVLDTNSCAYRFLLEPVQKSGFHLTVSQMLKNRK $\cdots \cdots$...... QEPLMSNED \\
\hline PDR3 & 805 & EPGLSDLLREFFDTRSFIYRYMLKSVEKSGFHLIIRKMLESDY-..-KFLYRDKLATG-. \\
\hline PDR8 & 608 & NERNKRLLKAV -...-SNFYQLTSTLAFERVSRVLFDKASQARIETEKIWLKKGINUVEHFS \\
\hline YRM1 & 642 & -DNNK QLRIIM -...-ARSYTFVINIALESIYRAVLEKVIKYRTEVENTWLQQLQOELNGS \\
\hline & 672 & -VGNKELIRTM-.--HRSSQFVIELAIERTYRTILGNVIEFRKLTEETWLAQIKQELDPQ \\
\hline \multirow[t]{2}{*}{ STBS } & 720 & - GASDSYQDILDENNVDVSWVOKLV*......... \\
\hline & & . \\
\hline PDR1 & 899 & NKQMKHNSGKNLNPDLPSLKTGTSCLLNGI - ESPQLPFNGRS - - APSPVRNNSLPEFAQ \\
\hline PDR3 & 859 & 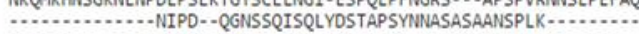 \\
\hline PDR8 & 664 & 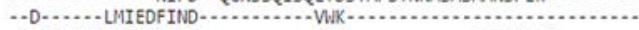 \\
\hline YRM1 & 697 & 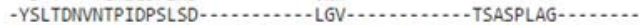 \\
\hline YRR1 & 727 & -SDNPSSEAKIVSDRQRD \\
\hline STB5 & 745 & \\
\hline
\end{tabular}

Figura 33. Comparación de las secuencias proteicas de factores de transcripción Pdr. Alineamiento múltiple de las secuencias proteicas de los factores de transcripción Pdr mediante programa CLUSTALW. En rojo se indica la región Zn-cluster DBD, y en verde se indica la principal región XBD. Los aminoácidos conservados están marcados en gris. 


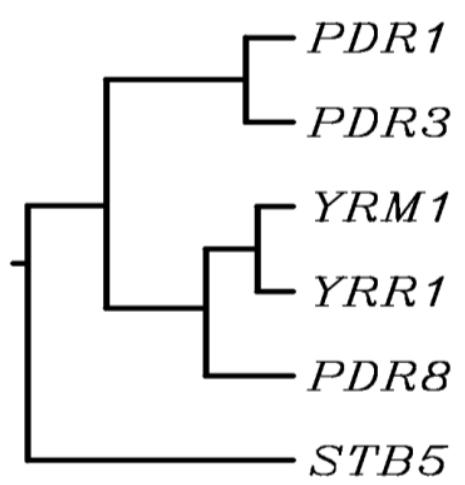

Figura 34. Representación filogenética de factores de transcripción Pdr.

En la representación del árbol de similitud de secuencia proteica entre los factores de transcripción Pdr (Figura 34), se observa cómo estos factores se agrupan entre sí formando tres "grupos": 1) Pdr1 y Pdr3, 2) Yrm1, Yrr1, y Pdr8, y 3) Stb5.

Tras hacer este estudio previo a nivel de secuencia de los factores de transcripción pasamos a analizar experimentalmente la capacidad de reconocimiento de estos factores a determinados compuestos.

\subsection{Estudio del reconocimiento y activación por compuestos químicos de los factores Pdr.}

Estudios previos han mostrado la capacidad de los factores de transcripción Pdr para reconocer y unirse directamente a diversos azoles (Thakur et al., 2008). En este trabajo, quisimos desarrollar un sistema experimental que nos permitiese determinar las sensibilidades y selectividades de la familia Pdr ante diversos xenobióticos. Las células del mutante $\Delta$ gal4 transformadas con ambos plásmidos (pGBKT7-Gal4 ${ }_{\mathrm{DBD}}-\mathrm{Pdr}$ y pAG413-GAL1 $1_{\text {UAS-lucCP }}{ }^{+}$) fueron sometidas a distintos rangos de concentraciones de citrinina (Figura 35), ocratoxina A (Figura 36), menadiona (Figura 37), y peróxido de hidrógeno (Figura 38). 

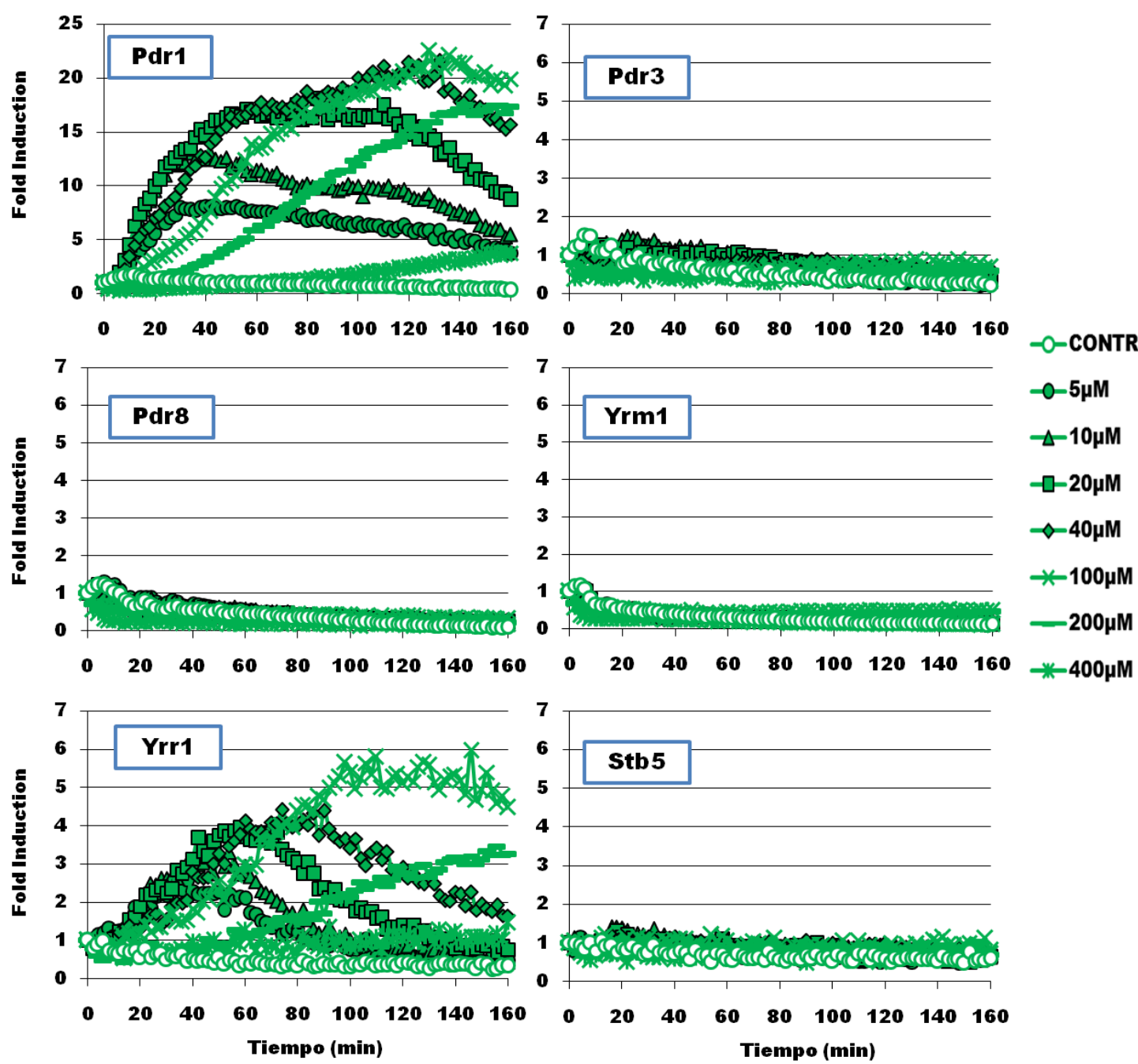

Figura 35. Comparación de perfiles de activación por citrinina de los factores de transcripción Pdr. Las células $\triangle$ gal4 con los plásmidos pAG413-GAL $\mathrm{UAS}^{-} \mathrm{lucCP}^{+}$y $\mathrm{pGBKT}-\mathrm{Gal}_{\mathrm{DBD}}-\mathrm{Pdr}$ específico para cada factor Pdr (Pdrl, Pdr3, Pdr8, Yrml, Yrrl y Stb5) se sometieron a un rango de concentraciones de citrinina (0, 5, 10, 20, 40, $100,200$, y $400 \mu \mathrm{M})$ y se cuantificó la actividad luciferasa con luminómetro por triplicado. Los resultados se muestran en niveles de inducción (Fold induction).

Los resultados en el tratamiento con citrinina (Figura 35) mostraron que dos factores de transcripción Pdr, Pdr1 e Yrr1, participarían en el reconocimiento de la toxina y activación del proceso de adaptación celular a ésta, siendo Pdr1 el regulador con mayor inducción de los dos. 

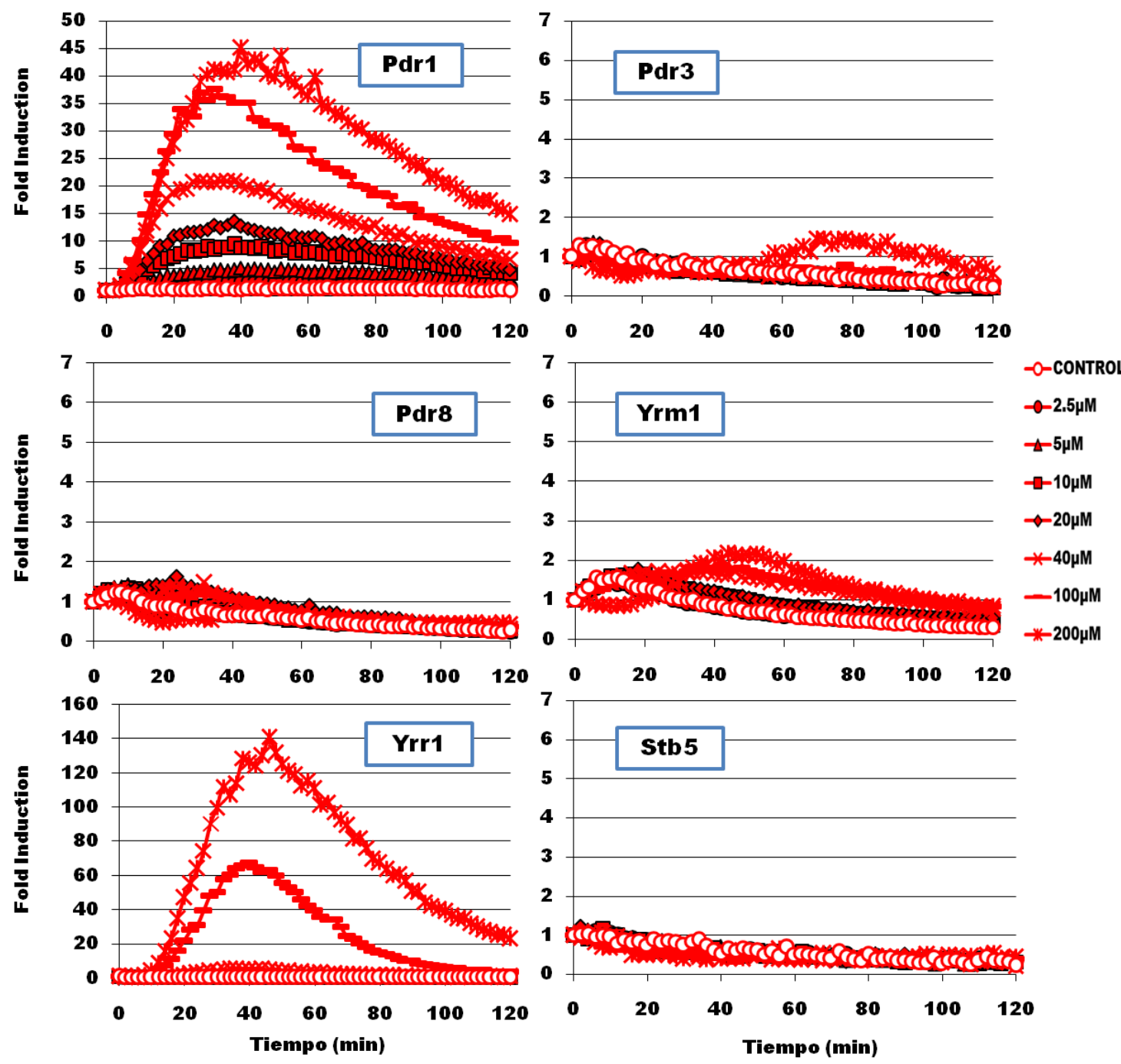

Figura 36. Comparación de perfiles de activación por ocratoxina A de los factores de transcripción Pdr. Las células $\Delta$ gal4 con los plásmidos pAG413-GA1L $\mathrm{UAS}_{-}-\mathrm{lucCP}^{+}$y $\mathrm{pGBKT}-\mathrm{Gal}{ }_{\mathrm{DBD}}-\mathrm{Pdr}$ específico para cada factor Pdr (Pdrl, Pdr3, Pdr8, Yrml, Yrrl y Stb5) se sometieron a un rango de concentraciones de ocratoxina A $(0,2.5,5,10$, $20,40,100$, y $200 \mu \mathrm{M})$ y se cuantificó la actividad luciferasa con luminómetro por triplicado. Los resultados se muestran en niveles de inducción (Fold induction).

En el caso del tratamiento con OTA (Figura 36), de nuevo, Pdr1 e Yrr1 mostraron los niveles de inducción más altos, pero, mientras que Pdr1 parece presentar una sensibilidad similar tanto para citrinina como ocratoxina A, Yrr1 parece ser capaz de discriminar entre ambas toxinas, presentando mayor sensibilidad a OTA, especialmente en las concentraciones más elevadas. Pero además de estudiar si estos factores Pdr eran capaces de activarse al tratar las células con micotoxinas, quisimos comprobar su capacidad de reconocimiento y activación por otros compuestos químicos relacionados con estrés oxidativo: menadiona y peróxido de hidrógeno. 

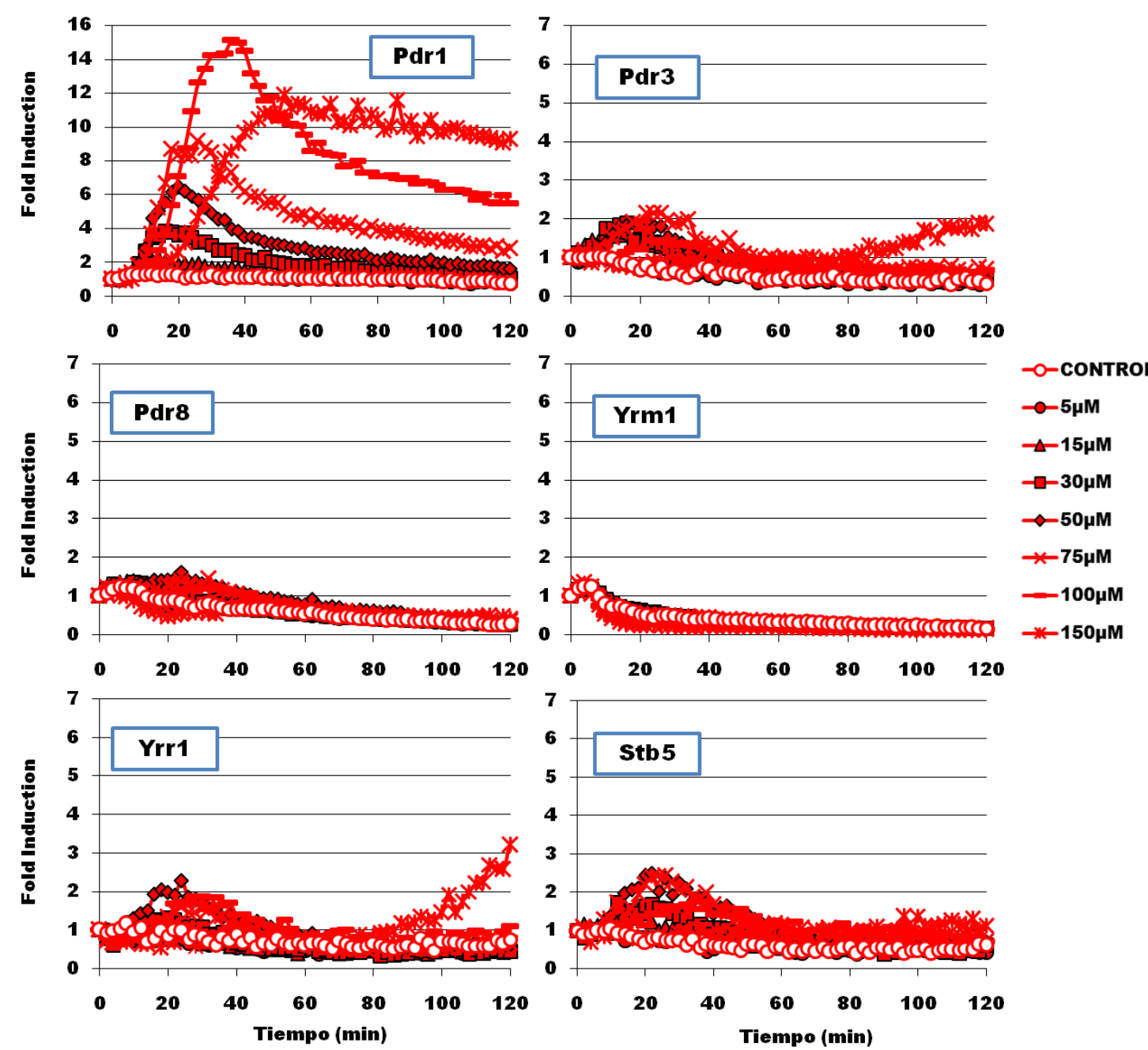

Figura 37. Comparación de perfiles de activación por menadiona de los factores de transcripción Pdr. Las células 4 gal4 con los plásmidos pAG413-GAL $\mathrm{UAS}_{-}-\mathrm{lucCP}^{+}$y pGBKT7-Gal4 $\mathrm{DBD}-\mathrm{Pdr}$ específico para cada factor Pdr (Pdrl, Pdr3, Pdr8, Yrml, Yrrl y Stb5) se sometieron a un rango de concentraciones de menadiona (0, 5, 15, 30, 50, $75,100$, y $150 \mu \mathrm{M})$ y se cuantificó la actividad luciferasa con luminómetro por triplicado. Los resultados se muestran en niveles de inducción (Fold induction).

Los resultados para el tratamiento con menadiona (Figura 37) mostraron inducción en Pdr1, saturándose a una concentración de $100 \mu \mathrm{M}$, mientras que en el caso del tratamiento con $\mathrm{H}_{2} \mathrm{O}_{2}$ (Figura 38) apenas muestra inducción. Por su parte, Stb5 muestra una inducción leve con menadiona, pero sí observamos actividad con peróxido de hidrógeno. 

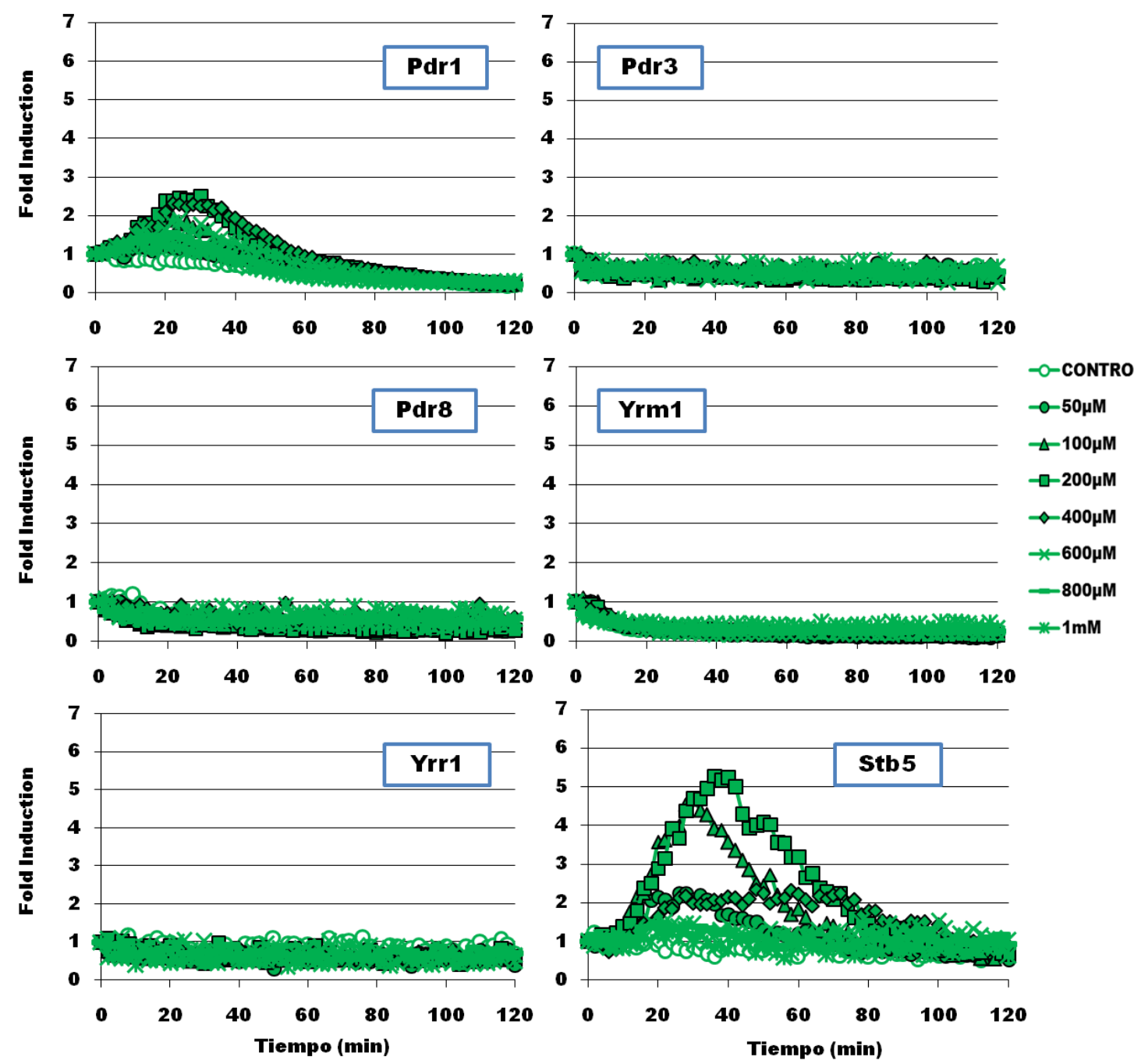

Figura 38. Comparación de perfiles de activación por $\mathrm{H}_{2} \mathrm{O}_{2}$ de los factores de transcripción Pdr. Las células $\triangle$ gal4 con los plásmidos pAG413-GAL $\mathrm{UAS}^{-} \mathrm{lucCP}^{+}$y pGBKT7-Gal4 $\mathrm{DBD}^{-\mathrm{Pdr}}$ específico para cada factor Pdr (Pdrl, Pdr3, Pdr8, Yrml, Yrrl y Stb5) se sometieron a un rango de concentraciones de $\mathrm{H}_{2} \mathrm{O}_{2}(0,50,100,200,400,600$, $800 \mu \mathrm{M}$, y $1 \mathrm{mM}$ ) y se cuantificó la actividad luciferasa con luminómetro por triplicado. Los resultados se muestran en niveles de inducción (Fold induction).

Los resultados de los cuatro tratamientos mostraron cómo Pdr1, aunque en menor proporción cuando las células son sometidas a $\mathrm{H}_{2} \mathrm{O}_{2}$, es capaz de reconocer y activar la expresión de proteínas en respuesta a todos los tratamientos, demostrando un alto grado de promiscuidad. A continuación, y para analizar los perfiles dosis-respuesta obtenidos de forma más detallada representamos los máximos de inducción de los distintos factores y tratamientos frente a la concentración (Figura 39). 

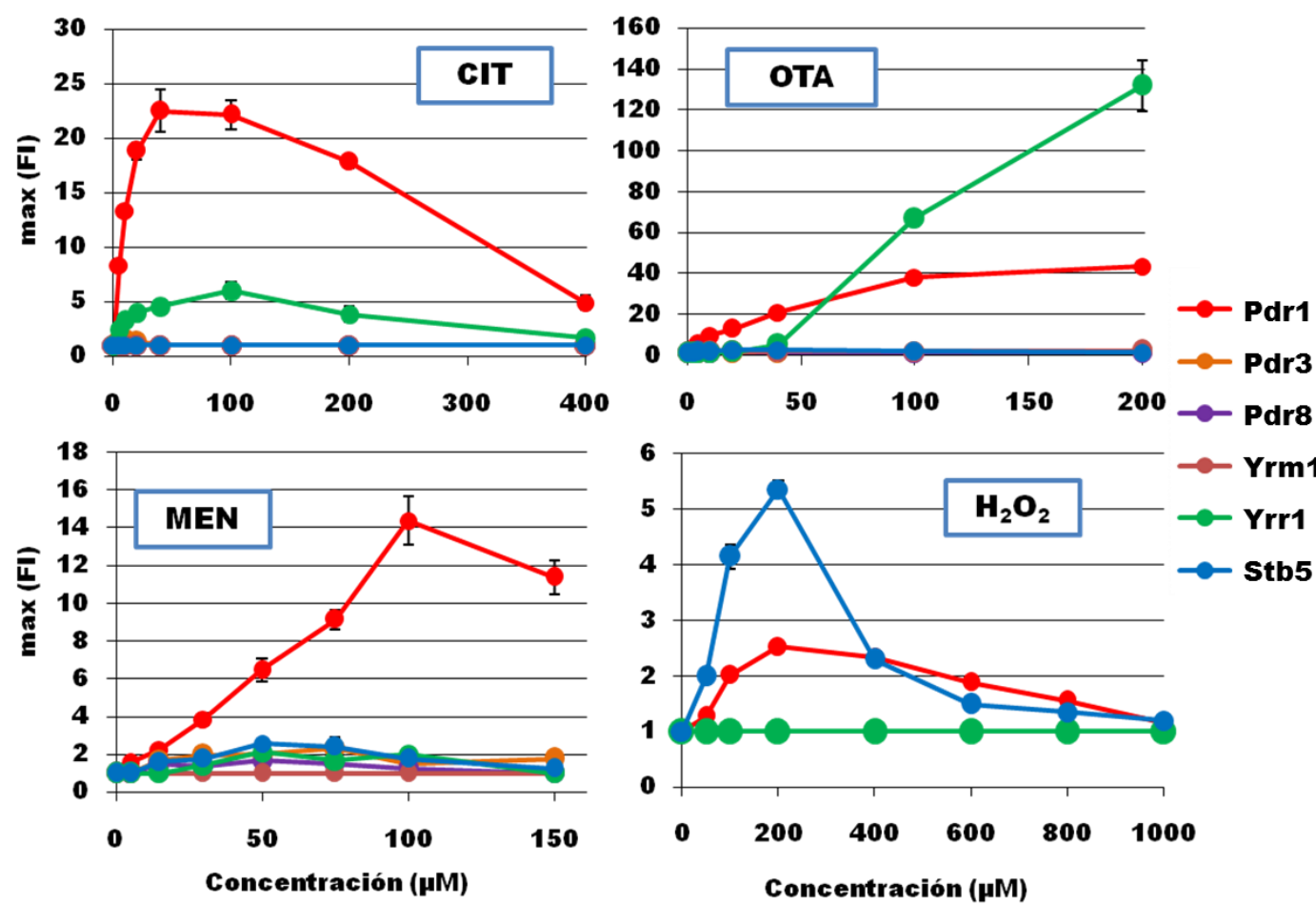

Figura 39. Comparación de los perfiles dosis-respuesta entre los factores transcripcionales Pdr en respuesta a diferentes xenobióticos. Representación de los valores máximos de inducción de los factores Pdr indicados en las células de levadura $\Delta g a l 4$ tratados con un rango de concentraciones de citrinina (CIT) $(0,5,10,20,40,100,200$, y $400 \mu \mathrm{M})$, ocratoxina A (OTA) $(0,2.5,5,10,20,40,100$, y $200 \mu \mathrm{M})$, menadiona (MEN) $(0,5,15,30,50,75,100$, y $150 \mu \mathrm{M})$, y peróxido de hidrógeno $\left(\mathrm{H}_{2} \mathrm{O}_{2}\right)(0,50,100,200,400,600,800 \mu \mathrm{M}$, y $1 \mathrm{mM})$ y cuantificando la actividad luciferasa con luminómetro por triplicado. Los resultados se muestran en niveles de inducción (Fold induction). Los valores máximos de inducción (FI) se representan frente a la concentración.

Al estudiar en conjunto los resultados de los experimentos luciferasa con los seis factores Pdr utilizados (Figura 39 y Figura 40) se observó que Pdr1 parece ser el factor principal, participando en mayor o menor medida en todos los tratamientos empleados. Pdr1 se activó de forma similar con citrinina y ocratoxina A, y de la misma forma parece ser el principal factor al someter las células a distintas condiciones de menadiona. Por el contrario, aunque se observó inducción en el tratamiento con peróxido de hidrógeno, ésta era muy leve. Entre el resto de factores Pdr, Yrr1 y Stb5 parecen ser los únicos con algún papel en la activación transcripcional de genes de defensa para alguno de los tratamientos estudiados. Yrr1 parece participar, junto con Pdr1, en la activación de la respuesta adaptativa a citrinina y ocratoxina A, aunque discriminando entre ambas drogas. Este factor presenta una inducción menor con CIT que con OTA, y además, se satura antes con la primera. De hecho, se observaron niveles de inducción bastantes elevados en el tratamiento con OTA a mayores concentraciones. Por su parte, Stb5 mostró actividad principalmente, aunque no muy elevada, en el tratamiento con peróxido de hidrogeno, y una inducción muy leve con menadiona. 

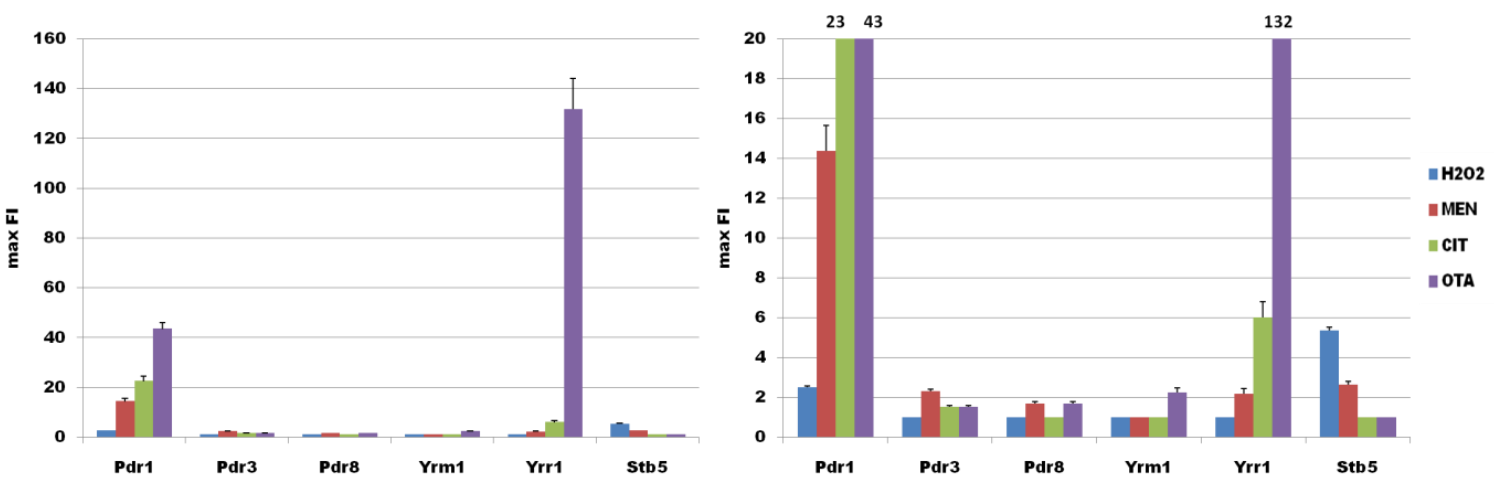

Figura 40. Comparación de los valores de inducción máxima entre los factores transcripcionales Pdr en respuesta a diferentes xenobióticos. Representación de los valores máximos de inducción de los factores Pdr indicados en las células de levadura $\Delta g a l 4$ tratados con un rango de concentraciones de citrinina (CIT) $(0,5,10,20$,

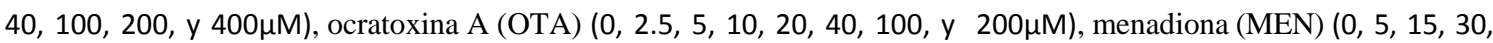
$50,75,100$, y $150 \mu \mathrm{M})$, y peróxido de hidrógeno $\left(\mathrm{H}_{2} \mathrm{O}_{2}\right)(0,50,100,200,400,600,800 \mu \mathrm{M}$, y $1 \mathrm{mM})$ y cuantificando la actividad luciferasa con luminómetro por triplicado. Los resultados se muestran en niveles de inducción (Fold induction). Los valores máximos de inducción (FI) se representan frente a los distintos factores de transcripción.

Por tanto, en esta parte de la presente tesis, se analizaron, por un lado los transportadores multidroga Pdr5, Pdr15, Snq2, y Yor1, y por otro, los factores de transcripción Pdr1, Pdr3, Pdr8, Yrm1, Yrr1, y Stb5, en respuesta a diversos tratamientos xenobióticos.

Los transportadores multidroga estudiados tienen una respuesta diferencial en función del compuesto estudiado y el transportador. Pudimos comprobar que Pdr5 y Snq2, son los más activos de los cuatro y suelen tener una respuesta rápida en los primeros instantes. Por el contrario, PDR15 también parece inducirse ante los xenobióticos estudiados, pero en niveles menores y como un actor secundario. Por su parte, YORI se induce muy poco ante CIT y OTA, y nada con menadiona y peróxido de hidrógeno. Además, cabe destacar, que sólo Snq2 muestra actividad en el tratamiento con $\mathrm{H}_{2} \mathrm{O}_{2}$, lo que pudiera tener relación con ser regulado con el factor de transcripción Stb5. De hecho, este factor de transcripción, ha sido el único que ha mostrado una activación significativa ante dicho compuesto, corroborando que participa en la respuesta ante estrés oxidativo.

Entre los factores de transcripción estudiados cabe destacar la importancia y promiscuidad de Pdr1. Este regulador participa en todos los tratamientos estudiados, aunque en menor medida ante peróxido de hidrógeno. Además, hemos comprobado que se encarga de la regulación de Pdr5, Pdr15, y Snq2 en tratamiento con CIT. De la misma manera, se ha podido observar que es el regulador principal en la respuesta ante CIT y OTA a través de los elementos PDRE. A pesar de ser considerado uno de los factores de transcripción principales en respuesta a xenobióticos, Pdr3 no parece tener una participación muy activa en la defensa ante las micotoxinas CIT y OTA, ni los oxidantes menadiona y peróxido de hidrógeno. Del resto de factores de transcripción estudiados, destacan Yrr1 en la respuesta a CIT y OTA, y Stb5 en la respuesta a $\mathrm{H}_{2} \mathrm{O}_{2}$. Yrr1 ha mostrado actividad en ambas toxinas, pero parece ser capaz de discriminar entre 
ambas, e inducir una gran activación ante OTA. Por su parte, Stb5, como se ha comentado anteriormente reconoce e induce la activación transcripcional ante $\mathrm{H}_{2} \mathrm{O}_{2}$. Pdr8 e Yrm1 no parecen tener gran participación en la respuesta de adaptación a estos compuestos, excepto como posibles reguladores negativos en respuesta al tratamiento con citrina a través de los elementos PDRE.

Por último, además de estudiar el papel de estos componentes del sistema PDR, también hemos desarrollado un sistema binario que nos ha permitido revelar las sensibilidades de los factores de transcripción Pdr específicamente, a distintas condiciones de estreses. Esta técnica nos puede servir para conocer más ampliamente y de forma rápida y sencilla, la participación a nivel individual de cada factor ante un amplio número de compuestos xenobióticos, como otras toxinas o fármacos. 

DISCUSIÓN 

La respuesta a xenobióticos permite a la célula a adaptarse y sobrevivir a la exposición ante gran variedad de compuestos exógenos, como toxinas o fármacos. En esta respuesta participan distintos tipos de proteínas, como transportadores de membrana, enzimas detoxificadoras, o factores de transcripción. En este trabajo nos hemos centrado en el papel de un conjunto de proteínas de las células de la levadura Saccharomyces cerevisiae que participan en la respuesta multidroga (MDR) o respuesta pleiotrópica a drogas (PDR). Los compuestos químicos estudiados fueron toxinas, concretamente las micotoxinas citrinina (CIT) y ocratoxina A (OTA), y otros dos compuestos químicos relacionados con la producción de estrés oxidativo, específicamente menadiona (MEN) y peróxido de hidrógeno $\left(\mathrm{H}_{2} \mathrm{O}_{2}\right)$ (Figura 41).

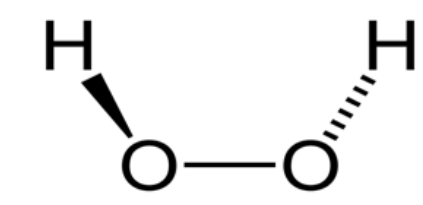

Peróxido de hidrógeno<smiles>CC1=C2C(=CO[C@@H](C)[C@@H]2C)C(O)=C(C(=O)O)C1=O</smiles>

Citrinina<smiles>CC1=CC(=O)c2ccccc2C1=O</smiles>

Menadiona<smiles>C[C@@H]1Cc2c(Cl)cc(C(=O)N[C@@H](Cc3ccccc3)C(=O)O)c(O)c2C(=O)O1</smiles>

Ocratoxina A

Figura 41. Estructura molecular de peróxido de hidrógeno, menadiona, citrinina, y ocratoxina A.

En la primera parte de este trabajo nos hemos centrado en tratar de comprender mejor cuales son los mecanismos de toxicidad de las micotoxinas citrinina y ocratoxina A. Las micotoxinas son metabolitos secundarios producidos por hongos filamentosos, muy diversas entre ellas y que pueden ser dañinas para el ser humano (Bennet and Klich, 2003). Entre este grupo tan variable de moléculas tóxicas se encuentran citrinina (CIT) y ocratoxina A (OTA). Para conocer mejor sus mecanismos de toxicidad empleamos la levadura Saccharomyces cerevisiae. Las células de levadura son un modelo excelente para estudiar la respuesta adaptativa a xenobióticos ya que han desarrollado sistemas de adaptación a estrés ambiental muy eficientes que activan rápidamente la transcripción de genes de defensa. CIT y OTA producen cambios importantes y rápidos en la expresión génica de levadura, por lo que la respuesta transcripcional de las células ante estas toxinas puede compararse de forma cuantitativa a tiempo real con distintos reporteros específicos, y también a nivel genómico. 
En estudios anteriores (Pascual-Ahuir et al., 2014) observamos cómo CIT era capaz de inducir rápidamente y de forma transitoria la activación de ciertos promotores de respuesta a estrés, y la posible implicación de proteínas de respuesta a estrés oxidativo y resistencia multidroga. Continuando con lo observado anteriormente, estudiamos la respuesta no sólo a CIT sino también a OTA en estos mismos promotores, puesto que ambas suelen presentarse juntas y en distintas ocasiones se ha indicado que pudieran tener un efecto sinérgico (Klaric et al., 2013) y sus mecanismos de toxicidad podrían estar ligados a la producción de estrés oxidativo (Sorrenti et al., 2013). Los resultados mostraron que ambas toxinas inducían una respuesta en los promotores estudiados, pero de forma diferencial, mucho menor en OTA. Aunque no tenemos datos cuantitativos, podemos suponer que esto es debido a la diferente implicación de estos promotores ante las micotoxinas y no a una menor acumulación en el interior de la célula de OTA, ya que observamos una rápida inducción y niveles de saturación a menores concentraciones. Por tanto, esto indicaría que los mecanismos de la activación génica de CIT y OTA no son los mismos. Además, contrariamente a lo esperado, no observamos efectos sinérgicos entre las dos micotoxinas, al no producirse aumento en la expresión génica ante la presencia de ambas.

Una estrategia de defensa en la detoxificación celular ante xenobióticos y otros compuestos tóxicos es la activación de transportadores de la membrana plasmática (Jungwirth and Kuchler, 2006). Pdr5 es uno de los transportadores de membrana en respuesta a xenobióticos más importante. Al estudiar y comparar los reporteros anteriormente empleados en mutantes defectuosos en la producción de este transportador, se comprobó que tenía un papel en la detoxificación celular de CIT y OTA, ya que estos mutantes respondían de forma más sensible ante ellas, con una clara inducción incluso en concentraciones menores. Esto podría ser debido a la acumulación de la toxina en el interior de la célula, ya que no podría eliminarla eficientemente.

Tras comprobar la alta sensibilidad de las células defectuosas para Pdr5, se empleó este mutante para realizar un experimento a nivel transcriptómico. Los tiempos y concentraciones fueron seleccionados a partir de los experimentos previos para tratar de optimizar el experimento, ya que son puntos críticos para la obtención de buenos resultados. Esto nos permitió identificar gran número de genes que respondían positivamente a la exposición a CIT y OTA, pero distintos en función del tratamiento. Este resultado indicaría que la reprogramación transcripcional que sucede tras exponer las células a estas toxinas es distinta en función de la micotoxina, es decir, que posiblemente la forma en que dañan a la célula sea diferente, ya que desencadenan la activación de estrategias de defensa distintas.

Citrinina induce la expresión de muchos genes, entre los cuales sobresalen los incluidos en los grupos funcionales de "transporte de drogas" y "respuesta a estrés oxidativo". Algunos de los genes más inducidos son codificantes de transportadores multidroga (FLR1, ATR1, SNQ2, PDR15, PDR10, PDR16, y YOR1), mayoritariamente localizados en la membrana plasmática. Lo que podría significar que gran parte del mecanismo de detoxificación celular de CIT, al menos en los primeros instantes, está basado en la 
eliminación de esta toxina de la célula. Estos datos se corresponderían con lo observado en los otros experimentos realizados con mutantes con pérdida de función, dónde se detectó sensibilidad por parte de Pdr5, Snq2, y en menor medida, Yor1, al ser tratados con CIT. Además, habría que recordar que en el ensayo transcriptómico empleamos un mutante $\Delta p d r 5$, por lo que algunos genes, de forma compensatoria podrían inducirse en mayor medida, mostrando un fenotipo menor en otros experimentos con CIT. Éste podría ser el caso con Yor1, puesto que se ha visto anteriormente que este transportador, junto con Pdr5 y Snq2, presentan actividad compensatoria en la defensa a drogas cuando alguno de ellos no es funcional (Kolaczkowska et al., 2008). Por su parte, OTA no parece producir un gran impacto en el transporte multidroga, ya que sólo se induce $S N Q 2$ y en menor intensidad que con CIT.

Ocratoxina A induce la activación de genes de grupos funcionales ligados a procesos de desarrollo del organismo, como la meiosis y la esporulación. Estos procesos, normales en células diploides de levadura bajo condiciones adecuadas (Govin and Berger, 2009; Winter, 2012), se encuentran reprimidos en células haploides como las empleadas en este trabajo. Esta represión génica es controlada epigenéticamente por factores específicos de unión a ADN que reclutan histona-desacetilasas como la sirtuina Hst1 en los genes de meiosis y esporulación (Grunstein and Gasser, 2013). Se desconoce cómo es el proceso de interferencia en este silenciamiento génico por parte de OTA, pero este mecanismo parece formar parte de la reprogramación génica en células cancerígenas (Chalkiadaki and Guarente, 2015), por lo que podría estar implicado en el posible efecto carcinogénico de ocratoxina A.

Citrinina y ocratoxina A han sido relacionadas con la producción de estrés oxidativo, especialmente en mamíferos (Sorrenti et al., 2013; Kumar et al., 2011; Pascual-Ahuir et $a l ., 2014)$. Los resultados de este trabajo mostraron que el mecanismo de toxicidad más predominante en los tratamientos con CIT era la inducción de estrés oxidativo. Tanto los reporteros luciferasa específicos de estrés como los mutantes defectuosos en la defensa antioxidante estudiados demostraron gran sensibilidad a esta micotoxina. Además, en el ensayo transcriptómico, como hemos comentado anteriormente, se activaron genes incluidos en grupos funcionales de respuesta a estrés oxidativo, y también, más concretamente, a especies reactivas de oxígeno (ROS), lo que sugiere que la producción de ROS es la principal causa de estrés oxidativo en los tratamientos con CIT. Estos resultados concuerdan con los obtenidos en otro estudio transcriptómico realizado previamente con citrinina en levadura (Iwahashi et al., 2007). Por su parte, OTA parece depender menos de la producción de estrés oxidativo para producir daño a las células. Tanto en el ensayo transcriptómico como en los experimentos con los reporteros luciferasa se observó una menor activación de genes implicados en esta respuesta, y con menor sensibilidad que con CIT. Por tanto, no parece que el estrés oxidativo sea el mecanismo de toxicidad primario, coincidiendo con algunos estudios en mamíferos donde se indica que el daño producido por OTA no podría ser explicado por daño oxidativo (Gayathri et al., 2015; Qi et al., 2014). Aún así, OTA, al igual que CIT, produce la inducción de diversos genes implicados en la defensa antioxidante, aunque 
éstos son distintos. OTA, por ejemplo, activa la expresión de catalasas mitocondriales/peroxisomales (Ctt1 y Cta1), mientras que CIT estimula las funciones enzimáticas implicadas en el metabolismo del glutatión (Ecm4, Glr1, Gtt2, y Grx2). Las diferencias observadas podrían significar que estas micotoxinas producen distintos tipos de especies ROS, de forma que la respuesta adaptativa celular es diferente.

Los resultados de este trabajo muestran que citrinina y ocratoxina A inducen distintas estrategias de defensa en las células, lo que sugiere mecanismos de toxicidad distintos. CIT parece causar estrés oxidativo como principal estrategia, mientras que OTA parece activar genes que normalmente se encuentran silenciados, como la esporulación.

Como hemos visto, los genes codificantes de transportadores multidroga se inducen rápidamente cuando son expuestos a CIT y, en menor medida, OTA. Estas proteínas de membrana están consideradas una primera estrategia de detoxificación de la célula al expulsar los compuestos dañinos, principalmente exógenos, de ésta (Jungwirth and Kuchler, 2006). En levadura, los transportadores multidroga de la membrana plasmática que eliminan estos compuestos de la célula forman parte del denominado sistema PDR (pleiotropic drug resistance).

El sistema PDR de levadura confiere a las células tolerancia a un amplio número de compuestos químicos exógenos así como a algunos compuestos tóxicos endógenos al expulsarlos fuera de éstas. Este sistema está compuesto por proteínas conservadas de bacterias a humanos, entre ellos, transportadores multidroga, pero también otro tipo de proteínas como factores de transcripción que se encargan de regular su expresión. En ocasiones, estos transportadores se encuentran sobreexpresados, lo que da lugar a un fenómeno conocido como resistencia pleiotrópica a drogas (PDR) o resistencia a múltiples drogas (MDR), de donde procede el nombre para este conjunto de proteínas. Este proceso de resistencia es de gran importancia en diversos tratamientos médicos, como quimioterapia en cáncer, o antifúngicos, ya que disminuyen su eficiencia (Holohan et al., 2013; Paul and Moye-Rowley, 2014). Por esto, estudiar el funcionamiento de este sistema es necesario para desarrollar estrategias que permitan reducir el fenómeno de resistencia. En este trabajo quisimos conocer mejor el funcionamiento del sistema PDR en levadura, concretamente de varios transportadores multidroga (Pdr5, Pdr15, Snq2, y Yor1) y factores de transcripción (Pdr1, Pdr3, Pdr8, Yrm1, Yrr1, y Stb5).

En primer lugar, se quiso conocer la participación de los transportadores Pdr5, Pdr15, Snq2, y Yor1 en la respuesta a citrinina, ocratoxina A, menadiona y peróxido de hidrógeno. Anteriormente, se comprobó que estos transportadores tenían un papel, en mayor o menor medida, en el proceso de adaptación celular frente a CIT y OTA, así que decidimos conocer mejor su perfil de respuesta empleando reporteros luciferasa integrativos. Los resultados mostraron comportamientos diferenciales entre transportadores y xenobióticos. Pdr5 y Snq2 parecen ser los transportadores principales en respuesta a las moléculas estudiadas, mientras que Pdr15 y Yor1 no parecen tener una participación tan importante, con valores de actividad mucho menores o casi 
inexistentes. Concretamente, al tratar las células con CIT, se observó una activación más rápida de $P D R 5$ y $S N Q 2$, que de $P D R 15$ y YOR1. Estos datos indicarían que Pdr5 y Snq2 actúan como transportadores primarios, mientras que Pdr15 y Yor1 serían transportadores secundarios en la respuesta a CIT. Varios estudios sugieren que Pdr5 y Pdr15 actúan de forma complementaria y no solapante en la detoxificación celular bajo distintas condiciones metabólicas o fases de crecimiento (Mamnun et al., 2004; Wolfger et al., 2004). Los resultados en CIT parecen indicar una posible actividad complementaria, almenos entre los dos grupos de transportadores, primarios $\mathrm{y}$ secundarios. Por otra parte, también se observa cierto solapamiento en reconocimiento de sustrato, especialmente entre Pdr5 y Snq2, aunque con distintas sensibilidades. Estos dos transportadores reconocen multitud de xenobióticos, en muchos casos, como se ha visto en otros estudios (Kolaczkowska et al., 2008) solapándose y compensando defectos de función. Esta capacidad de reconocimiento cooperativa podría permitir una mayor eficiencia en la detoxificación de las moléculas tóxicas durante los primeros instantes de exposición.

La capacidad para reconocer gran número de sustratos viene dada por la especificidad de los dominios transmembrana (TMD) (Prasad and Goffeau, 2012), pero estudios entre transportadores con funciones similares y estructura distinta, como P-glicoproteína y Pdr5, indicaban que el comportamiento dinámico de estas proteínas, es también importante (Ernst et al., 2010). Además, en tratamientos antifúngicos, la capacidad de compensación de función y solapamiento de reconocimiento de sustrato entre transportadores supone un gran obstáculo (Kolaczkowska et al., 2008). Esto coincide con los actuales estudios para desarrollar nuevas terapias frente a la resistencia multidroga. Estas investigaciones, al no obtener el resultado esperado con inhibidores directos de transportadores, se están centrando en disminuir la resistencia multidroga a través del control de la regulación de los transportadores, con RNA de interferencia o moduladores epigenéticos (Robey et al., 2018; Chen et al., 2016; Li et al., 2016). Por ello, conocer cómo está regulada la respuesta en MDR parece un paso fundamental.

En las células de levadura, como en otros hongos y células humanas, las moléculas tóxicas son directamente detectadas por ciertos factores de transcripción, que a su vez, activan la expresión de genes de transportadores de membrana para tratar de eliminar los agentes tóxicos del interior de la célula (Thakur et al., 2008). En este trabajo, junto con el análisis y cuantificación de expresión luciferasa en promotores o sitios de reconocimiento concretos, desarrollamos un sistema binario de plásmidos que nos permitiera estudiar la respuesta a xenobióticos de varios factores de transcripción de forma individualizada. Este es posible al combinar un plásmido con las regiones de reconocimiento de sustrato (XBD) y activación (AD) (X-TAD), que se activa específicamente tras el reconocimiento del sustrato, con otro plásmido que contiene el gen de la luciferasa desestabilizada. De esta forma pudimos estudiar más concretamente la especificidad de dichos reguladores.

La expresión de los transportadores PDR está controlada por varios factores de transcripción entre los que destacan Pdr1 y Pdr3. Pdr1 y Pdr3 regulan la transcripción 
de los genes diana a través de sitios de unión en el promotor del gen y que se denominan elementos PDRE. Nuestros resultados muestran que Pdr1 participa en la respuesta de todas las moléculas estudiadas, en mayor o menor medida. Este regulador transcripcional parece ser un factor imprescindible en la activación de los transportadores Pdr5, Pdr15 y Snq2 en la respuesta a CIT, ya que en el ensayo con mutantes defectuosos de función de Pdr1 no había inducción de los genes codificantes para estos transportadores. Por su parte, Pdr3 parece interactuar de forma diferencial en función del transportador, como regulador positivo en el caso de $S N Q 2$, o negativo en el caso de PDR5 y PDR15. De todas formas, excepto con PDR15, al que parece reprimir de forma más llamativa no parece tener una presencia fundamental en los otros dos transportadores. Esta capacidad de modulación de la regulación, positiva y negativa, coincide con lo descrito para estos dos factores de transcripción por Mamnun et al., 2002, dónde se comprobó que Pdr1 y Pdr3 eran muy versátiles en la regulación de Pdr5, Snq2 y Yor1 a través de los sitios PDRE, formando homo- y heterodímeros. Nuestros resultados parecen coincidir con este estudio, además de incluir el transportador Pdr15. En general, podemos pensar que el mecanismo más directo de regulación negativa entre los factores de transcripción Pdr sería la competición por la unión al elemento PDRE entre un Pdr que no reconoce el xenobiótico (como Pdr3 o Yrm1) con uno que realmente lo hace.

Pdr1 también mostró un papel fundamental en la respuesta a CIT y OTA a través de los elementos PDRE en el ensayo comparativo con mutantes defectuosos de función para distintos factores de transcripción Pdr con reporteros luciferasa. De nuevo, en los mutantes $\Delta p d r l$ no había inducción de expresión luciferasa. Contrariamente, otros dos mutantes de deleción presentaron altos niveles de inducción: $\Delta p d r 8$ e $4 y r m 1$. Pdr8 e Yrm1 están poco descritos. Son dos factores de transcripción Pdr, homólogos del factor de transcripción Yrr1. Además, Pdr8 parece formar parte de la regulación del transportador multidroga Yor1 (Hikkel et al., 2003). Estos datos podrían sugerir una regulación negativa de Pdr8 sobre Yor1 en el tratamiento con CIT, explicando el nivel inferior de expresión con respecto al resto de transportadores.

La última aproximación experimental con los factores de transcripción del sistema PDR la realizamos desarrollando un sistema binario de plásmidos que nos permitiera analizar su respuesta a distintas moléculas tóxicas de forma individual a través de la región XBD. Esta variación con respecto a los otros ensayos luciferasa nos permite aumentar la sensibilidad y especificidad del experimento. Los resultados volvieron a mostrar la importancia de Pdr1. Este factor de transcripción volvió a aparecer activo en todos los tratamientos realizados, aunque con niveles distintos, lo que indicaría diferencias en la capacidad de reconocimiento de las distintas moléculas estudiadas. Entre el resto de factores de transcripción estudiados, cabe destacar a Yrr1 y Stb5. Yrr1 mostró inducción tanto en CIT como en OTA, pero los perfiles de la respuesta fueron distintos, indicando que es capaz de discriminar entre ambas moléculas. Hemos visto que tanto Pdr1 como Yrr1 reconocen y activan la expresión génica en respuesta a CIT y OTA, pero, sin embargo, en el estudio de los elementos PDRE, el mutante con falta de función de Yrr1 
no presentó diferencias con la cepa silvestre, mientras que en $\Delta p d r 1$ no había inducción. Por ello, podemos inferir que Yrr1 activa la respuesta a estas micotoxinas a través de otros sitios de reconocimiento, lo que coincidiría con estudios anteriores (Le Crom S, et $a l ., 2002)$. Por su parte, Stb5 fue el factor de transcripción más activo ante la presencia de peróxido de hidrógeno. Esto coincide con lo conocido hasta ahora de este factor, y es que es importante para la respuesta antioxidante de la levadura de forma aparentemente independiente del factor de transcripción Yap1 (Akache and Turcotte, 2002). De hecho, datos recientes de nuestro laboratorio demuestran que Stb5 responde a $\mathrm{H}_{2} \mathrm{O}_{2}$ de forma más sensible que Yap1 y activa la transcripción a través de elementos PDRE independientemente de Pdr1.

Yrr1 y Stb5 son reguladores de algunos transportadores multidroga. Yrr1 está implicado en el control de Snq2 y Yor1, mientras que Stb5 se encarga de Snq2. Esto parece coincidir, parcialmente, con lo visto en la respuesta a los distintos tratamientos por parte de los transportadores. Si nos centramos en Snq2, podemos decir que se activa de forma similar a Pdr1 e Yrr1 en los tratamientos de CIT y OTA, y a Stb5 en el tratamiento con $\mathrm{H}_{2} \mathrm{O}_{2}$. Sin embargo, en el caso de Yor1, regulado también por Pdr1 e Yrr1, la respuesta es muy diferente. Estos resultados muestran, una vez más, la complejidad de los circuitos regulatorios en la respuesta multidroga. Podemos hacer varias suposiciones de porqué obtenemos estos perfiles de activación distintos. Por un lado, podría ser que algunos promotores tengan más elementos PDRE, de forma que se produzca un mayor número de interacciones entre los factores de transcripción y el promotor, pero, por otro lado, parece más probable que la afinidad por los diferentes PDRE varíe en función del factor de transcripción. Por ejemplo, si comparamos los resultados de los experimentos de los transportadores con los obtenidos empleando el sistema binario, vemos similitud en la respuesta entre ciertos transportadores y factores de transcripción, como PDR5 y Pdr1 o $S N Q 2$ e Yrr1 en los tratamientos con CIT y OTA, y $S N Q 2$ y Stb5, con $\mathrm{H}_{2} \mathrm{O}_{2}$.

Otro dato a tener en cuenta en la regulación de la respuesta multidroga es la capacidad de algunos de estos factores a formar homo- y heterodímeros. Pdr1 y Pdr3 forman heterodímeros en muchas ocasiones (Mamnun et al., 2002), y también se sabe que Stb5 está activo formando heterodímero con Pdr1 (Akache and Turcotte, 2002; Larochelle et al., 2006). ¿Pero cuál es la función biológica? Esta conformación podría tener una función moduladora de la expresión, y de especificidad. Por un lado, se reprime la expresión, como en el caso del factor Rdr1 que forma heterodímeros con Pdr1 o Pdr3 compitiendo para unirse a los elementos PDRE (Hellauer et al., 2002). Por otro lado, y siempre como una suposición, ya que no tenemos datos experimentales que lo corroboren, la formación de heterodímeros podría aumentar la especificidad y eficiencia de algunos factores de transcripción. Pdr1 es el factor de transcripción del sistema PDR más abundante, encontrándose de forma constitutiva en el núcleo alrededor de 1300 moléculas/celula, mientras que de Pdr3 y Stb5 encuentramos 166 y 279 moléculas/célula, respectivamente (Ghaemmaghami et al., 2003). Los datos presentados en este trabajo muestran que Pdr1 presenta una gran promiscuidad en reconocimiento y respuesta a distintos xenobióticos, por lo que, capaz de formar tanto homo- como 
heterodímeros, podría actúar de primera respuesta, y además, aumentar la eficiencia de la respuesta celular al formar heterodímeros con factores de transcripción menos abundantes y más específicos.

Otro punto a destacar en este trabajo, fue el desarrollo de una variante del sistema luciferasa desestabilizada que nos permitiera estudiar de forma individual la activación de los factores de transcripción Pdr. Una característica importante de este sistema es que todos los factores Pdr estudiados tienen la misma afinidad de unión a ADN debido a su fusión con Gal4 $4_{D B D}$, ya que de esta forma podemos ver si hay activación sin depender de qué elementos de unión a ADN reconocen ni las diferencias de afinidad. Este sistema binario nos permitió determinar en tiempo real la sensibilidad de respuesta del sistema multidroga a diferentes moléculas, concretamente, citrinina, ocratoxina A, menadiona y peróxido de hidrógeno, y la posibilidad de ampliar el estudio a otras, como fármacos. La aplicación de gradientes complejos de fármacos de interés permitiría determinar de forma cuantitativa la sensibilidad con la cual interacciona cada fármaco con los diferentes factores Pdr del sistema multidroga. Este conocimiento forma la base para estudiar tratamientos que evitan la respuesta pleiotrópica a fármacos por potenciales inhibidores del sistema multidroga. El sistema binario se podría aplicar por tanto a estudios más biomédicos de la inhibición del sistema PDR para determinar de forma rápida y cuantitativa el grado de eficiencia de estos inhibidores.

En resumen, la resistencia multidroga supone un grave problema en el desarrollo de terapias farmacológicas a distintas patologías, ya sea cáncer, infecciones bacterianas, o enfermedades neurológicas. Aquí, hemos tratado de comprender un poco mejor el funcionamiento del sistema PDR de Saccharomyces cerevisiae desde los transportadores multidroga a los factores de transcripción que los regulan empleando varios xenobióticos. Pdr5 y Snq2 se han presentado como los transportadores multidroga más activos, seguidos de Pdr15. Por otra parte, los resultados mostraron el papel de Pdr1 como factor de transcripción principal en esta respuesta. Además, otros factores parecen participar de forma más específica en función del sustrato, como reguladores negativos en el caso de Pdr8, e Yrm1, como reguladores positivos, como Pdr1, Yrr1, y Stb5, o en el caso de Pdr3, como ambos. Aunque el control de Pdr1 sobre la respuesta de los transportadores a xenobióticos parece clara, todavía quedan preguntas sobre el modo en que este factor es capaz de reconocer tantas moléculas distintas y generar respuestas de defensa específicas. Por ello, pudiera ser que la cooperación con otros factores de transcripción, como los antes mencionados permitan un aumento en la especificidad de la respuesta. Lo que está claro, es que es necesario continuar estudiando esta red de regulación tan compleja que permita desarrollar nuevas estrategias más eficientes en tratamientos farmacológicos. 
CONCLUSIONES 

Las conclusiones obtenidas a partir de los resultados del presente trabajo son las siguientes:

1. Las micotoxinas citrinina y ocratoxina A inducen la expresión de genes para la defensa a estrés de forma dosis-dependiente.

2. Citrinina y ocratoxina A provocan respuestas transcriptómicas diferentes en levadura indicando mecanismos de toxicidad distintos para estas micotoxinas.

3. Citrinina induce fuertemente la expresión de sistemas antioxidantes y de transporte de drogas, y su toxicidad incrementa en mutantes con defectos en la defensa a estrés oxidativo y el transporte multidroga, como $\Delta y a p 1$ y $\Delta s n q 2$.

4. Ocratoxina A parece desreprimir genes del desarrollo, concretamente de la meiosis y esporulación, y sólo activa ligeramente la defensa antioxidante.

5. Los xenobióticos citrinina, ocratoxina A, menadiona, y peróxido de hidrógeno, activan la expresión génica de los transportadores multidroga Pdr5, Pdr15, Snq2, y Yor1 con sensibilidades distinguibles.

6. Pdr5 y Snq2 son los transportadores multidroga más expresados en presencia de citrinina, ocratoxina A y menadiona, y sólo $S N Q 2$ se induce en respuesta a peróxido de hidrógeno.

7. Pdr1, pero no Pdr3, es el factor de transcripción con mayor importancia para la activación de genes multidroga en respuesta a citrinina.

8. Los activadores transcripcionales del sistema PDR responden de forma diferencial a peróxido de hidrógeno, menadiona, citrinina y ocratoxina A.

9. Pdr1 es fundamental en la respuesta a citrinina y ocratoxina A a través de los elementos PDRE, y participa en la activación transcripcional en respuesta a los cuatro xenobióticos estudiados, pero en menor medida frente a peróxido de hidrógeno.

10. Yrr1 participa en la activación transcripcional de genes en respuesta a citrinina y a ocratoxina A de forma diferencial, y Stb5 produce la activación de la expresión génica ante peróxido de hidrógeno. 
Conclusiones

11. El empleo de reporteros luciferasa in vivo permite descrifar de forma cuantitativa vías de toxicidad y selectividades de activadores del sistema multidroga en respuesta a diferentes clases de xenobióticos. 


\section{BIBLIOGRAFÍA}



Afshari CA, Hamadeh HK, Bushel PR (2011). The evolution of bioinformatics in toxicology: Advancing toxicogenomics. Toxicol. Sci., 120 (Suppl. 1), S225-S237

Akache B, MacPherson S, Sylvain MA, Turcotte B (2004) Complex interplay among regulators of drug resistance genes in Saccharomyces cerevisiae.J Biol Chem 279(27):27855-60

Akache B, Turcotte B (2002) New regulators of drug sensitivity in the family of yeast zinc cluster proteins. J Biol Chem277(24):21254-60

Arbillaga L, Azqueta A, van Delft JH, Lopez de Cerain A (2007). In vitro gene expression data supporting a DNA non-reactive genotoxic mechanism for ochratoxin A. Toxicol. Appl. Pharmacol., 220: 216-224

Balzi, E., Chen,W., Ulaszewski,S., Capieaux,E., and Goffeau,A. (1987). The multidrug resistance gene PDRl from Saccharomyces cerevisiae.J. Biol. Chem. 262, 16871-16879.

Balzi E, Wang M, Leterme S, Van Dyck L, Goffeau A (1994). PDR5, a novel yeast multidrug resistance conferring transporter controlled by the transcription regulator PDR1.J Biol Chem. 269(3):2206-14.

Bennett, JW, Klich M. (2003). Mycotoxins.Clin.Microbiol. Rev. 16, 497-516

Bouslimi A, Ouannes Z, Golli EE, Bouaziz C, Hassen W, Bacha H (2008). Cytotoxicity and oxidative damage in kidney cells exposed to the mycotoxins ochratoxin a and citrinin: Individual and combined effects. Toxicol. Mech. Methods18, 341-349

Bragulat MR, Martinez E, Castella G, Cabanes FJ (2008). Ochratoxin A and citrinin producing species of the genus Penicillium from feedstuffs.Int. J. Food. Microbiol.126, 43-48.

Cabrito T, Remy E, Teixeira M, Duque P and Sá-correia I (2011). Resistance to Herbicides in the Model Organisms Saccharomyces cerevisiae and Arabidopsis thaliana: the Involvement of Multidrug Resistance Transporters. Herbicides and Environment.IntechOpen, DOI: 10.5772/13057.

Cabrito T, Teixeira M, Singh A, Prasad R, Sá-Correia I (2011). The yeast ABC transporter Pdr18 (ORF YNR070w) controls plasma membrane sterol composition, playing a role in multidrug resistance. Biochem J. 440(2):195-202.

Cadenas E, Davies KJA (2000) Mitochondrial free radical generation, oxidative stress and aging. Free Radical Biology \& Medicine 29 (3/4): 222-230

Cannon RD, Lamping E, Holmes AR, Niimi K, Baret PV, Keniya MV, Tanabe K, Niimi M, Goffeau A, Monk BC (2009) Efflux-mediated antifungal drug resistance.Clin Microbiol Rev 22(2):291-321 
Causton HC, Ren B, Koh SS, Harbison CT, Kanin E, Jennings EG, Lee TI, True HL, Lander ES, Young RA (2001) Remodeling of yeast genome expression in response to environmental changes. Molecular biology of the Cell 12: 323-337

Chalkiadaki, A, Guarente, L (2015).The multifaceted functions of sirtuins in cancer.Nat. Rev. Cancer15:608-624

Chan WH (2007). Citrinin induces apoptosis via a mitochondria-dependent pathway and inhibition of survival signals in embryonic stem cells, and causes developmental injury in blastocysts. Biochem. J. 404, 317-326.

Chen Z, Shi T, Zhang L, Zhu P, Deng M, Huang C, Hu T, Jiang L, Li J (2016). Mammalian drug efflux transporters of the ATP binding cassette (ABC) family in multidrug resistance: A review of the past decade.Cancer Lett.370(1):153-64

Conte SS, Lloyd AM (2011). Exploring multiple drug and herbicide resistance in plants--spotlight on transporter proteins.Plant Sci. 180(2):196-203.

Cui Z, Hirata D, Tsuchiya E, Osada H, Miyakawa T (1996). The multidrug resistanceassociated protein (MRP) subfamily (Yrs1/Yor1) of Saccharomyces cerevisiae is important for the tolerance to a broad range of organic anions.J Biol Chem. 271(25):14712-6.

Cui Z, Shiraki T, Hirata D, Miyakawa T (1998) Yeast gene YRR1, which is required for resistance to 4-nitroquinoline $\mathrm{N}$-oxide, mediates transcriptional activation of the multidrug resistance transporter gene SNQ2. Mol Microbiol29(5):1307-15

de Nadal E, Ammerer G, Posas F. (2011) Controlling gene expression in response to stress. Nature Reviews Genetics12, 833-845

Dean M, Annilo T (2005). Evolution of the ATP-binding cassette (ABC) transporter superfamily in vertebrates.Annu Rev Genomics Hum Genet.6:123-42.

Decottignies A, Grant AM, Nichols JW, de Wet H, McIntosh DB, Goffeau A (1998) ATPase and multidrug transport activities of the overexpressed yeast $\mathrm{ABC}$ protein Yor1p. J Biol Chem273(20):12612-22

Delahodde A, Delaveau T, Jacq C (1995) Positive autoregulation of the yeast transcription factor Pdr3p, which is involved in control of drug resistance. Mol Cell Biol15(8):4043-51

Delaveau,T.,Delahodde,A.,Carvajal,E.,Subik,J.,andJacq,C.(1994). PDR3, a new yeast regulatory gene, is homologous to $P D R 1$ and controls the multidrug resistance phenomenon. Mol.Gen.Genet. 244, 501-511.

Doi K, Uetsuka K (2014). Mechanisms of Mycotoxin-induced Dermal Toxicity and Tumorigenesis through Oxidative Stress-related Pathways.J. Toxicol. Pathol.27, 1-10. 
Dolz-Edo L, Rienzo A, Poveda-Huertes D, Pascual-Ahuir A, Proft M (2013) Deciphering dynamic dose responses of natural promoters and single cis elements upon osmotic and oxidative stress in yeast. Mol Cell Biol33(11):2228-40

Dos Santos SC, Teixeira MC, Cabrito TR, Sá-Correia I (2012) Yeast toxicogenomics: genome-wide responses to chemical stresses with impact in environmental health, pharmacology, and biotechnology. Front Genet $3: 63$

Ernst R, Klemm R, Schmitt L, Kuchler K (2005) Yeast ATP-binding cassette transporters: cellular cleaning pumps. Methods Enzymol 400:460-84

Ernst R, Kueppers P, Stindt J, Kuchler K, Schmitt L (2010) Multidrug efflux pumps: substrate selection in ATP-binding cassette multidrug efflux pumps--first come, first served? FEBS J. 277(3):540-9.

Escriva L, Font G, Manyes L (2015). In vivo toxicity studies of fusarium mycotoxins in the last decade: A review. Food. Chem. Toxicol. 78, 185-206

Faucet V, Pfohl-Leszkowicz A, Dai J, Castegnaro M, Manderville RA (2004).Evidence for covalent DNA adduction by Ochratoxin A following chronic exposure to rat and subacute exposure to pig.Chem. Res. Toxicol. 17, 1289-1296.

Flajs D, Peraica M (2009). Toxicological properties of citrinin.Arh.Hig. Rada Toksikol. 60, 457-464.

Fletcher JI, Williams RT, Henderson MJ, Norris MD, Haber M (2016). ABC transporters as mediators of drug resistance and contributors to cancer cell biology. Drug Resist Updat.26:1-9

Follmann W, Behm C, Degen GH (2014). Toxicity of the mycotoxin citrinin and its metabolite dihydrocitrinone and of mixtures of citrinin and ochratoxin A in vitro. Arch. Toxicol. 88, 1097-1107

Gasch AP, Spellman PT, Kao CM, Carmel-Harel O, Eisen MB, Storz G, Botstein D, Brown PO (2000) Genomic expression programs in the response of yeast cells to environmental changes. Molecular Biology of the Cell 11: 4241-4257

Gayathri, L.; Dhivya, R.; Dhanasekaran, D.; Periasamy, V.S.; Alshatwi, A.A.; Akbarsha, M.A. (2015) Hepatotoxiceffect of ochratoxin A and citrinin, alone and in combination, and protective effect of vitamin E: In vitrostudy in HepG2 cell. Food Chem. Toxicol.83, 151-163.

Ghaemmaghami S, Huh WK, Bower K, Howson RW, Belle A, Dephoure N, O'Shea EK, Weissman JS (2003) Global analysis of protein expression in yeast. Nature425(6959):737-41

Govin J, Berger SL (2009) Genome reprogramming during sporulation. Int J Dev Biol 53(2-3):425-32 
Grunstein M, Gasser SM (2013) Epigenetics in Saccharomyces cerevisiae. Cold Spring Harb Perspect Biol 5(7)

Güldener U, Heck S, Fielder T, Beinhauer J, Hegemann JH (1996) A new efficient gene disruption cassette for repeated use in budding yeast. Nucleic Acids Res24(13):2519-24

Halliwell B (2006) Oxidative stress and neurodegeneration: where are we now? Journal of Neurochemistry, 97: 1634-1658.

Hatzixanthis K, Mollapour M, Seymour I, Bauer BE, Krapf G, Schüller C, Kuchler K, Piper PW (2003). Moderately lipophilic carboxylate compounds are the selective inducers of the Saccharomyces cerevisiae Pdr12p ATP-binding cassette transporter. Yeast.20(7):575-85.

Hellauer, K., Akache, B., MacPherson, S., Sirard, E. and Turcotte, B. Zinc cluster protein Rdr1p is a transcriptional repressor of the PDR5 gene encoding a multidrug transporter. J. Biol. Chem. 277 (2002) 17671-17676.

Hellauer K, Rochon MH, Turcotte B (1996) A novel DNA binding motif for yeast zinc cluster proteins: the Leu3p and Pdr3p transcriptional activators recognize everted repeats. Mol Cell Biol16(11):6096-102

Hibi D, Kijima A, Kuroda K, Suzuki Y, Ishii Y, Jin M, Nakajima M, Sugita-Konishi Y, Yanai T, Nohmi T, et al.(2013). Molecular mechanisms underlying ochratoxin Ainduced genotoxicity: Global gene expression analysis suggests induction of DNA double-strand breaks and cell cycle progression. J. Toxicol. Sci., 38: 57-69

Hikkel I, Lucau-Danila A, Delaveau T, Marc P, Devaux F, Jacq C (2003) A general strategy to uncover transcription factor properties identifies a new regulator of drug resistance in yeast. J Biol Chem278(13):11427-32

Hlavácek O, Kucerová H, Harant K, Palková Z, Váchová L (2009) Putative role for $\mathrm{ABC}$ multidrug exporters in yeast quorum sensing. FEBS Lett 583(7):1107-13

Holohan C, Schaeybroeck SV, Longley DB, Johnston PG (2013). Cancer drug resistance: an evolving paradigm. Nature Reviews Cancer 13: 714-726

Hundhausen C, Boesch-Saadatmandi C, Matzner N, Lang F, Blank R, Wolffram S, Blaschek W, Rimbach G (2008). Ochratoxin a lowers mRNA levels of genes encoding for key proteins of liver cell metabolism. Cancer Genom.Proteom.,5: 319-332.

Iwahashi H, Kitagawa E, Suzuki Y, Ueda Y, Ishizawa YH, Nobumasa H, Kuboki Y, Hosoda H, Iwahashi Y (2007). Evaluation of toxicity of the mycotoxin citrinin using yeast ORF DNA microarray and Oligo DNA microarray.BMC Genomics, 8: 95

Jamieson DJ (1998). Oxidative stress responses of the yeast Saccharomyces cerevisiae.Yeast14: 1511-1527 
Jungwirth H, Kuchler K. (2006) Yeast ABC transporters-- a tale of sex, stress, drugs and aging. FEBS Lett, 580(4):1131-8

Katzmann DJ, Hallstrom TC, Mahé Y, Moye-Rowley WS (1996) Multiple Pdr1p/Pdr3p binding sites are essential for normal expression of the ATP binding cassette transporter protein-encoding gene PDR5. J Biol Chem271(38):23049-54

Kihara A, Igarashi Y (2004) Cross talk between sphingolipids and glycerophospholipids in the establishment of plasma membrane asymmetry. Mol Biol Cell 15(11):4949-59

Klaric MS, Rasic D, Peraica M (2013). Deleterious effects of mycotoxin combinations involving ochratoxin A. Toxins5, 1965-1987

Klotz LO, Steinbrenner H (2017). Cellular adaptation to xenobiotics: Interplay between xenosensors, reactive oxygen species and FOXO transcription factors. Redox Biology13: 646-654

Kolaczkowska A, Goffeau A (1999) Regulation of pleiotropic drug resistance in yeast. Drug Resist Updat2(6):403-414

Kolaczkowska A, Kolaczkowski M, Goffeau A, Moye-Rowley WS (2008) Compensatory activation of the multidrug transporters Pdr5p, Snq2p, and Yor1p by Pdr1p in Saccharomyces cerevisiae. FEBS Lett582(6):977-83

Kolaczkowski, M., Kolaczowska, A., Luczynski, J., Witek, S. and Goffeau, A. (1998) In vivo characterization of the drug resistance profile of the major $\mathrm{ABC}$ transporters and other components of the yeast pleiotropic drug resistance network. Microb. Drug Resist. 4, 143-158.

Koszegi T, Poor M (2016). Ochratoxin A: Molecular Interactions, Mechanisms of Toxicity and Prevention at the Molecular Level. Toxins, 8.

Kumar M, Dwivedi P, Sharma AK, Sankar M, Patil RD, Singh ND (2014). Apoptosis and lipid peroxidation in ochratoxin A- and citrinin-induced nephrotoxicity in rabbits.Toxicol. Ind. Health30, 90-98.

Kumar R, Dwivedi PD, Dhawan A, Das M, Ansari KM (2011). Citrinin-generated reactive oxygen species cause cell cycle arrest leading to apoptosis via the intrinsic mitochondrial pathway in mouse skin. Toxicol. Sci. 122, 557-566.

Larochelle M, Drouin S, Robert F, Turcotte B (2006) Oxidative stress-activated zinc cluster protein Stb5 has dual activator/repressor functions required for pentose phosphate pathway regulation and NADPH production. Mol Cell Biol26(17):6690-701

Le Crom S, et al. (2002) New insights into the pleiotropic drug resistance network from genome-wide characterization of the YRR1 transcription factor regulation system. $\mathrm{Mol}$ Cell Biol22(8):2642-9 
Leppert G, McDevitt R, Falco SC, Van Dyk TK, Ficke MB, Golin J (1990) Cloning by gene amplification of two loci conferring multiple drug resistance in Saccharomyces. Genetics 125(1):13-20

Li W, Zhang H, Assaraf YG, Zhao K, Xu X, Xie J, Yang DH, Chen ZS (2016). Overcoming ABC transporter-mediated multidrug resistance: Molecular mechanisms and novel therapeutic drug strategies.Drug Resist Updat.27:14-29

López-Maury L, Marguerat S, Bähler J. (2008) Tuning gene expression to changing environments: from rapid responses to evolutionary adaptation. Nature Reviews Genetics9, 583-893

Löscher W, Potschka H (2005). Drug resistance in brain diseases and the role of drug efflux transporters.Nat Rev Neurosci.6(8):591-602

Lucau-Danila A, Delaveau T, Lelandais G, Devaux F, Jacq C (2003) Competitive promoter occupancy by two yeast paralogous transcription factors controlling the multidrug resistance phenomenon. J Biol Chem278(52):52641-50

Mahé Y, Lemoine Y, Kuchler K (1996). The ATP binding cassette transporters Pdr5 and Snq2 of Saccharomyces cerevisiae can mediate transport of steroids in vivo. J Biol Chem.271(41):25167-72.

Mamnun YM, Pandjaitan R, Mahé Y, Delahodde A, Kuchler K (2002) The yeast zinc finger regulators Pdr1p and Pdr3p control pleiotropic drug resistance (PDR) as homoand heterodimers in vivo. Mol Microbiol46(5):1429-40

Mamnun YM, Schüller C, Kuchler K (2004) Expression regulation of the yeast PDR5 ATP-binding cassette $(\mathrm{ABC})$ transporter suggests a role in cellular detoxification during the exponential growth phase. FEBS Lett 559(1-3):111-7

Mantle PG, Faucet-Marquis V, Manderville RA, Squillaci B, Pfohl-Leszkowicz A (2010). Structures of covalent adducts between DNA and Ochratoxin A: A new factor in debate about genotoxicity and human risk assessment. Chem. Res. Toxicol. 23, 8998.

Marin-Kuan M, Nestler S, Verguet C, Bezencon C, Piguet D, Mansourian R, Holzwarth J, Grigorov M, Delatour T, Mantle P, et al. (2006) A toxicogenomics approach to identify new plausible epigenetic mechanisms of ochratoxin a carcinogenicity in rat. Toxicol. Sci., 89: 120-134

Marroquin-Cardona AG, Johnson NM, Phillips TD, Hayes AW (2014). Mycotoxins in a changing global environment-A review.Food Chem. Toxicol, 69, 220-230

Miyahara K, Mizunuma M, Hirata D, Tsuchiya E, Miyakawa T (1996) The involvement of the Saccharomyces cerevisiae multidrug resistance transporters Pdr5p and Snq2p in cation resistance. FEBS Lett 399(3):317-20 
Mobius N, Hertweck C (2009). Fungal phytotoxins as mediators of virulence.Curr.Opin.Plant. Biol. 12, 390-398.

Morano KA, Grant CM, Moye-Rowley WS (2012) The response to heat shock and oxidative stress in Saccharomyces cerevisiae. Genetics, 190: 1157-1195

Moretti A, Susca A, Mule G, Logrieco AF, Proctor RH (2013). Molecular biodiversity of mycotoxigenic fungi that threaten food safety.Int. J. Food Microbiol.167, 57-66.

Murphy MP (2009) How mitocondria produce reactive oxygen species.Biochemical Journal417: 1-13

Ni L, Bruce C, Hart C, Leigh-Bell J, Gelperin D, Umansky L, Gerstein MB, Snyder M (2009) Dynamic and complex transcription factor binding during an inducible response in yeast. Genes \& Development 23: 1351-1363

Nishikawa JL, Boeszoermenyi A, Vale-Silva LA, Torelli R, Posteraro B, Sohn YJ, Ji F, Gelev V, Sanglard D, Sanguinetti M, Sadreyev RI, Mukherjee G, Bhyravabhotla J, Buhrlage SJ, Gray NS, Wagner G, Näär AM, Arthanari H (2016) Inhibiting fungal multidrug resistance by disrupting an activator-Mediator interaction. Nature530(7591):485-9

Ostry V, Malir F, Ruprich J (2013). Producers and important dietary sources of ochratoxin A and citrinin.Toxins5, 1574-1586

Pagano G, Manini P, Bagchi D (2003). Oxidative stress-related mechanisms are associated with xenobiotics exerting excess toxicity to Fanconi Anemia cells. Enviromental Health Perspectives, 111(14): 1699-1703

Pascual-Ahuir A, Vanacloig-Pedros E, Proft M (2014). Toxicity mechanisms of the food contaminant citrinin: Application of a quantitative yeast model. Nutrients6, 20772087

Paul S, Moye-Rowley WS (2014) Multidrug resistance in fungi: regulation of transporter-encoding gene expression. Front. Physiol. 5:143.

Paumi CM, Chuk M, Snider J, Stagljar I, Michaelis S (2009). ABC transporters in Saccharomyces cerevisiae and their interactors: new technology advances the biology of the ABCC (MRP) subfamily. Microbiol Mol Biol Rev. 73(4):577-93

Pfohl-Leszkowicz A, Manderville R.A (2012). An update on direct genotoxicity as a molecular mechanism of ochratoxin a carcinogenicity. Chem. Res. Toxicol. 25, 252262.

Piper P, Mahé Y, Thompson S, Pandjaitan R, Holyoak C, Egner R, Mühlbauer M, Coote $\mathrm{P}$, Kuchler K (1998). The pdr12 ABC transporter is required for the development of weak organic acid resistance in yeast. EMBO J. 17(15):4257-65. 
Prasad R, Goffeau A (2012). Yeast ATP-binding cassette transporters conferring multidrug resistance. Annu Rev Microbiol.66:39-63

Prasad R, Rawal MK (2014) Efflux pump proteins in antifungal resistance. Front. Pharmacol. 5:202

Prunuske AJ, Waltner JK, Kuhn P, Gu B, Craig EA (2012) Role for the molecular chaperones Zuo1 and Ssz1 in quorum sensing via activation of the transcription factor Pdr1. Proc Natl Acad Sci U S A109(2):472-7

Qi, X.; Yu, T.; Zhu, L.; Gao, J.; He, X.; Huang, K.; Luo, Y.; Xu,W.(2014) Ochratoxin A induces rat renal carcinogenicity with limited induction of oxidative stress responses. Toxicol. Appl. Pharmacol. 280, 543-549.

Rahimtula AD, Bereziat JC, Bussacchini-Griot V, Bartsch H (1988). Lipid peroxidation as a possible cause of ochratoxin A toxicity. Biochem.Pharmacol.37, 4469-4477

Ribeiro SM, Chagas GM, Campello AP, Kluppel ML (1997). Mechanism of citrinininduced dysfunction of mitochondria. V. Effect on the homeostasis of the reactive oxygen species. Cell.Biochem.Funct.15, 203-209

Rienzo A, Pascual-Ahuir A, Proft M (2012) The use of a real-time luciferase assay to quantify gene expression dynamics in the living yeast cell. Yeast29(6):219-31

Robey RW, Pluchino KM, Hall MD, Fojo AT, Bates SE, Gottesman MM (2018) Revisiting the role of $\mathrm{ABC}$ transporters in multidrug-resistant cancer. Nat Rev Cancer.doi: 10.1038/s41568-018-0005-8.

Rockwell NC, Wolfger H, Kuchler K, Thorner J (2009). ABC transporter Pdr10 regulates the membrane microenvironment of Pdr12 in Saccharomyces cerevisiae. $J$ Membr Biol. 229(1):27-52.

Rogers B, Decottignies A, Kolaczkowski M, Caravajal E, Balzi E, Goffeau A. The pleiotropic drug ABC transporters from Saccharomyces cerevisiae.J Mol Microbiol Biotechnol.2001; 3:207-214.

Sá-Correia I, dos Santos SC, Teixeira MC, Cabrito TR, Mira NP (2009) Drug:H+ antiporters in chemical stress response in yeast. Trends in Microbiology, 17 (1): 22 - 31

Schieber M, Chandel NS (2014) ROS function in redox signaling and oxidative stress. Current Biology24: R453-R462

Schmidt-Heydt M, Graf E, Stoll D, Geisen R (2012). The biosynthesis of ochratoxin A by Penicillium as one mechanism for adaptation to $\mathrm{NaCl}$ rich foods.Food Microbiol.29, 233-241

Schmidt-Heydt M, Stoll D, Schutz P, Geisen R (2015). Oxidative stress induces the biosynthesis of citrinin by Penicillium verrucosum at the expense of ochratoxin. Int. J. Food Microbiol.192, 1-6. 
Sena LA, Chandel NS (2012) Physiological roles of mitocondrial reactiva oxygen species. Molecular Cell48

Servos J, Haase E, Brendel M (1993). Gene SNQ2 of Saccharomyces cerevisiae, which confers resistance to 4-nitroquinoline-N-oxide and other chemicals, encodes a $169 \mathrm{kDa}$ protein homologous to ATP-dependent permeases. Mol Gen Genet.236(2-3):214-8.

Sies H, Oxidative stress: introductory remarks, in: H.Sies (Ed.), Oxidative Stress, AcademicPress, London (1985), pp.1-8.

Sies H (2015) Oxidative stress: a concept in redox biology and medicine. Redox Biology4: 180-183

Sorrenti V, di Giacomo C, Acquaviva R, Barbagallo I, Bognanno M, Galvano F (2013). Toxicity of ochratoxin a and its modulation by antioxidants: A review. Toxins $\mathbf{5}, 1742-$ 1766

Stoll D, Schmidt-Heydt M, Geisen R (2013). Differences in the regulation of ochratoxin A by the HOG pathway in Penicillium and Aspergillus in response to high osmolar environments.Toxins5, 1282-1298

Taymaz-Nikerel H, Cankorur-Cetinkaya A, Kirdar B. (2016) Genome-Wide transcriptional response of Saccharomyces cerevisiae to stress-induced perturbations. Frontiers in Bioengineering and Biotechnology4: 17

Teixeira MC, Dias PJ, Simões T, Sá-Correia I (2008) Yeast adaptation to mancozeb involves the up-regulation of FLR1 under the coordinate control of Yap1, Rpn4, Pdr3, and Yrr1. Biochem Biophys Res Commun367(2):249-55

Teixeira MC, Duque P, Sá-Correia I (2007). Environmental genomics: mechanistic insights into toxicity of and resistance to the herbicide 2,4-D. Trends Biotechnol. 25(8):363-70

Thakur JK, Arthanari H, Yang F, Pan SJ, Fan X, Breger J, Frueh DP, Gulshan K, Li DK, Mylonakis E, Struhl K, Moye-Rowley WS, Cormack BP, Wagner G, Näär AM (2008) A nuclear receptor-like pathway regulating multidrug resistance in fungi. Nature452(7187):604-9

Thorpe, G. W., Fong, C. S., Alic, N., Higgins, V. J., \& Dawes, I. W. (2004). Cells have distinct mechanisms to maintain protection against different reactive oxygen species: Oxidative-stress-response genes. Proceedings of the National Academy of Sciences of the United States of America, 101(17), 6564-6569.

Vakifahmetoglu-Norberg H, Ouchida AT, Norberg E (2017). The role of mitocondria in metabolism and cell death.Biochemical and Biophysical Research Communications, 482: 426-431 
van Veen HW, Konings WN (1997). Multidrug transporters from bacteria to man: similarities in structure and function. Semin Cancer Biol. 8(3):183-91.

Vanacloig-Pedros, E., Bets-Plasencia, C., Pascual-Ahuir, A., Proft, M. (2015).Coordinated Gene Regulation in the Initial Phase of Salt Stress Adaptation.Journal of Biological Chemistry, 290(16), 10163-10175

Vettorazzi A, Gonzalez-Penas E, de Cerain AL (2014). Ochratoxin A kinetics: A review of analytical methods and studies in rat model. Food Chem. Toxicol.72, 273-288.

Vettorazzi A, van Delft J, Lopez de Cerain A (2013). A review on ochratoxin A transcriptomic studies. Food Chem. Toxicol., 59: 766-783.

Vihervaara A, Duarte FM, Lis JT. (2018) Molecular mechanisms driving transcriptional stress responses.Nature Reviews Geneticsdoi:10.1038/s41576-018-0001-6

Vrabcheva T, Usleber E, Dietrich R, Martlbauer E (2000). Co-occurrence of ochratoxin $\mathrm{A}$ and citrinin in cereals from Bulgarian villages with a history of Balkan endemic nephropathy.J. Agric. Food. Chem. 48, 2483-2488.

Wang YM, Ong SS, Chai SC, Chen T (2012).Role of CAR and PXR in xenobiotic sensing and metabolism.Expert Opin Drug Metab Toxicol.8(7):803-17

Wang Y, Wang L, Liu F, Wang Q, Selvaraj JN, Xing F, Zhao Y, Liu Y (2016). Ochratoxin A Producing Fungi, Biosynthetic Pathway and Regulatory Mechanisms.Toxins, 8.

Wilcox LJ, Balderes DA, Wharton B, Tinkelenberg AH, Rao G, Sturley SL (2002) Transcriptional profiling identifies two members of the ATP-binding cassette transporter superfamily required for sterol uptake in yeast. J Biol Chem277(36):3246672

Winter E (2012) The Sum1/Ndt80 transcriptional switch and commitment to meiosis in Saccharomyces cerevisiae.Microbiol Mol Biol Rev76(1):1-15

Wolfger H, Mahé Y, Parle-McDermott A, Delahodde A, Kuchler K (1997). The yeast ATP binding cassette (ABC) protein genes PDR10 and PDR15 are novel targets for the Pdr1 and Pdr3 transcriptional regulators. FEBS Lett.418(3):269-74.

Wolfger H, Mamnun YM, Kuchler K (2004). The yeast Pdr15p ATP-binding cassette $(\mathrm{ABC})$ protein is a general stress response factor implicated in cellular detoxification. $J$ Biol Chem. 279(12):11593-9.

Wu F, Groopman JD, Pestka JJ (2014). Public health impacts of foodborne mycotoxins. Annu. Rev. Food Sci. Technol. 5, 351-372.

Yan J, Xie W (2016) A brief history of the discovery of PXR and CAR as xenobiotic receptors.Acta Pharm Sin B. 6(5):450-452 
Yasokawa D, Iwahashi H (2010). Toxicogenomics using yeast DNA microarrays. $J$. Biosci. Bioeng.,110: 511-522.

Ye ZW, Zhang J, Towsend DM, Tew KD (2015) Oxidative stress, redox regulation and diseases of celular differentiation.Biochimica et Biophysica Acta, 1850: 1607-1621

Yu FY, Lia, YC, Chang CH, Liu BH (2006). Citrinin induces apoptosis in HL-60 cells via activation of the mitochondrial pathway. Toxicol.Lett.161, 143-151

Zhang X, Cui Z, Miyakawa T, Moye-Rowley WS (2001) Cross-talk between transcriptional regulators of multidrug resistance in Saccharomyces cerevisiae.J Biol Chem276(12):8812-9 



\section{TABLAS}

SUPLEMENTARIAS 

Tabla suplementaria 1. Cepas silvestres y mutantes de deleción.

\begin{tabular}{|c|c|c|}
\hline Cepa & Genotipo & Procedencia \\
\hline BY4741 & 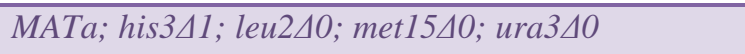 & EUROSCARF \\
\hline$\Delta p d r 1$ & BY4741 withpdr1::KANMX4 & EUROSCARF \\
\hline$\Delta p d r 3$ & BY4741 with $p d r 3:: K A N M X 4$ & EUROSCARF \\
\hline$\Delta p d r 1$ & BY4741 withpdr1::HIS3 & Este trabajo \\
\hline$\Delta p d r 3$ & BY4741 with $p d r 3:: H I S 3$ & Este trabajo \\
\hline$\Delta p d r 5$ & BY4741 with $p d r 5:: K A N M X 4$ & EUROSCARF \\
\hline$\Delta p d r 8$ & BY4741 with $p d r 8:: K A N M X 4$ & EUROSCARF \\
\hline$\Delta s k n 7$ & BY4741 with skn7::KANMX4 & EUROSCARF \\
\hline$\Delta s n q 2$ & BY4741 with snq2::KANMX4 & EUROSCARF \\
\hline$\Delta y a p 1$ & BY4741 with yap $1: \because K A N M X 4$ & EUROSCARF \\
\hline$\Delta y o r 1$ & BY4741 with yorl::KANMX4 & EUROSCARF \\
\hline$\Delta y r m 1$ & BY4741 with yrm1::KANMX4 & EUROSCARF \\
\hline$\Delta y r r 1$ & BY4741 with $y r r 1:: K A N M X 4$ & EUROSCARF \\
\hline W303-1A & $\begin{array}{l}\text { MATa; can1-100, his3-11'15, leu2-3'112, trp1-1, } \\
\text { ura3-1, ade2-1 }\end{array}$ & Ramón Serrano \\
\hline$\triangle g a l 4$ & W303-1A with gal4 $\because K A N M X 4$ & Este trabajo \\
\hline
\end{tabular}

Tabla suplementaria 2. Cepas con construcción plasmídica lucCP+

\begin{tabular}{|c|c|c|}
\hline Cepa & Genotipo & Procedencia \\
\hline $\begin{array}{l}\text { BY4741-3xAP1- } \\
\text { lucCP }^{+}\end{array}$ & BY4741 with plasmid pAG413-3xAP1-LucCP ${ }^{+}$ & $\begin{array}{l}\text { MarkusProft / Amparo } \\
\text { Pascual }\end{array}$ \\
\hline $\begin{array}{l}\text { BY4741-GRE2- } \\
\text { lucCP }^{+}\end{array}$ & BY4741 with plasmid pAG413-GRE2-LucCP ${ }^{+}$ & $\begin{array}{l}\text { MarkusProft / Amparo } \\
\text { Pascual }\end{array}$ \\
\hline$\Delta p d r 5$-GRE2-lucCP ${ }^{+}$ & $\begin{array}{l}\text { BY4741 with } p d r 5:: K A N \text { with plasmid pAG413- } \\
\text { GRE2-lucCP }^{+}\end{array}$ & Este trabajo \\
\hline $\begin{array}{l}\text { BY4741-SOD2- } \\
\text { lucCP }^{+}\end{array}$ & BY4741 with plasmid pAG413-SOD2-LucCP ${ }^{+}$ & $\begin{array}{l}\text { MarkusProft / Amparo } \\
\text { Pascual }\end{array}$ \\
\hline$\Delta p d r 5$-SOD2-lucCP ${ }^{+}$ & $\begin{array}{l}\text { BY4741 with } p d r 5:: K A N \text { with plasmid pAG413- } \\
\text { SOD2-lucCP }^{+}\end{array}$ & Este trabajo \\
\hline $\begin{array}{l}\text { BY4741-3xPDRE- } \\
\text { lucCP }^{+}\end{array}$ & BY4741 with plasmid pAG413-3xPDRE-LucCP ${ }^{+}$ & Este trabajo \\
\hline $\begin{array}{l}\Delta p d r 1-3 x P D R E- \\
\text { lucCP }^{+}\end{array}$ & $\begin{array}{l}\text { BY4741 with } p d r 1:: K A N \text { with plasmid pAG413- } \\
\text { 3xPDRE-lucCP }{ }^{+}\end{array}$ & Este trabajo \\
\hline $\begin{array}{l}\Delta p d r 3-3 x P D R E- \\
\text { lucCP }^{+}\end{array}$ & $\begin{array}{l}\text { BY4741 with } p d r 3:: K A N \text { with plasmid pAG413- } \\
\text { 3xPDRE-lucCP }{ }^{+}\end{array}$ & Este trabajo \\
\hline
\end{tabular}




\begin{tabular}{|c|c|}
\hline $\begin{array}{l}\Delta p d r 8-3 \times P D R E- \\
\text { lucCP }^{+}\end{array}$ & $\begin{array}{l}\text { BY4741 with } p d r 8:: K A N \text { with plasmid pAG413- Este trabajo } \\
\text { 3xPDRE-lucCP }{ }^{+}\end{array}$ \\
\hline $\begin{array}{l}\text { Syrm1-3xPDRE- } \\
\text { lucCP }^{+}\end{array}$ & $\begin{array}{l}\text { BY4741 with } y r m 1:: K A N \text { with plasmid pAG413- Este trabajo } \\
3 \times \text { PDRE-lucCP }^{+}\end{array}$ \\
\hline $\begin{array}{l}\text { Ayrrl-3xPDRE- } \\
\text { lucCP }^{+}\end{array}$ & $\begin{array}{l}\text { BY4741 with } y r r 1:: K A N \text { with plasmid pAG413- Este trabajo } \\
3 \times x_{D R E-l u c C P}{ }^{+}\end{array}$ \\
\hline
\end{tabular}

Tabla suplementaria 3. Cepas con construcción integrativa lucCP+.

\begin{tabular}{|c|c|c|}
\hline Cepa & Genotipo & Procedencia \\
\hline PDR5-lucCP+ & BY4741 with pPDR5-lucCP+-CYC1T-KANMX4 & $\begin{array}{l}\text { MarkusProft/Amparo } \\
\text { Pascual }\end{array}$ \\
\hline PDR15-lucCP+ & BY4741 with pPDR15-lucCP+-CYC1T-KANMX4 & $\begin{array}{l}\text { MarkusProft/Amparo } \\
\text { Pascual }\end{array}$ \\
\hline SNQ2-lucCP+ & BY4741 with pSNQ2-lucCP+-CYC1T-KANMX4 & $\begin{array}{l}\text { MarkusProft/Amparo } \\
\text { Pascual }\end{array}$ \\
\hline YOR1-lucCP+ & BY4741 with pYOR1-lucCP+-CYC1T-KANMX4 & $\begin{array}{l}\text { MarkusProft/Amparo } \\
\text { Pascual }\end{array}$ \\
\hline$\Delta p d r 1$-PDR5-lucCP+ & $\begin{array}{l}\text { BY4741 with pdrl::HIS3 with pPDR5-lucCP+- } \\
\text { CYC1T-KANMX4 }\end{array}$ & Este trabajo \\
\hline $\begin{array}{l}\Delta p d r 1-P D R 15- \\
\text { lucCP+ }\end{array}$ & $\begin{array}{l}\text { BY4741 with pdrl::HIS3 with pPDR15-lucCP+- } \\
\text { CYC1T-KANMX4 }\end{array}$ & Este trabajo \\
\hline$\Delta p d r 1-S N Q 2-l u c C P+$ & $\begin{array}{l}\text { BY4741 with pdrl::HIS3 with pSNQ2-lucCP+- } \\
\text { CYC1T-KANMX4 }\end{array}$ & Este trabajo \\
\hline$\Delta p d r 3-P D R 5-l u c C P+$ & $\begin{array}{l}\text { BY4741 with pdr3::HIS3 with pPDR5-lucCP+- } \\
\text { CYC1T-KANMX4 }\end{array}$ & Este trabajo \\
\hline $\begin{array}{l}\Delta p d r 3 \text {-PDR15- } \\
\text { lucCP+ }\end{array}$ & $\begin{array}{l}\text { BY4741 with pdr3::HIS3 with pPDR15-lucCP+- } \\
\text { CYC1T-KANMX4 }\end{array}$ & Este trabajo \\
\hline$\Delta p d r 3-\mathrm{SNQ2-lucCP+}$ & $\begin{array}{l}\text { BY4741 with pdr3::HIS3 with pSNQ2-lucCP+- } \\
\text { CYC1T-KANMX4 }\end{array}$ & Este trabajo \\
\hline
\end{tabular}

Tabla suplementaria 4. Cepas con construcción de sistema binario.

\begin{tabular}{|c|c|c|}
\hline Cepa & Genotipo & Procedencia \\
\hline $\begin{array}{l}\triangle \text { gal4-Pdr1- } \text { GAL }_{\mathrm{UAS}}- \\
\text { lucCP}^{+}\end{array}$ & $\begin{array}{l}\text { W303-1A gal4::KANMX4 con pGBKT7-ADH1p- } \\
\text { Gal4 }_{\text {DBD-Pdr1-myc y pAG413-GAL }} \text { - }{ }_{\text {UAS }}-\text { lucCP }^{+}\end{array}$ & Este trabajo \\
\hline $\begin{array}{l}\triangle \text { gal4-Pdr3- } \text { GAL }_{\mathrm{UAS}}- \\
\text { lucCP}^{+}\end{array}$ & $\begin{array}{l}\text { W303-1A gal4::KANMX4 con pGBKT7-ADH1p- } \\
\text { Gal4 }_{\text {DBD-Pdr3-myc y pAG413-GAL }} \text { - }{ }_{\text {UAS }}-\text { lucCP }^{+}\end{array}$ & Este trabajo \\
\hline$\triangle$ gal4-Pdr8- GAL $_{\mathrm{UAS}}$ - & W303-1A gal4::KANMX4 con pGBKT7-ADH1p- & Este trabajo \\
\hline
\end{tabular}




\begin{tabular}{|c|c|}
\hline lucCP ${ }^{+}$ & $\mathrm{Gal}_{\mathrm{DBD}}-\mathrm{Pdr} 8-\mathrm{myc}$ y pAG413-GAL $\mathrm{UAS}-\mathrm{lucCP}^{+}$ \\
\hline $\begin{array}{l}\text { ¿gal4-Yrm1- GAL }{ }_{\text {UAS }} \\
\text {-lucCP }\end{array}$ & $\begin{array}{l}\text { W303-1A gal4::KANMX4 con pGBKT7-ADH1p- Este trabajo } \\
\text { Gal4 }_{\mathrm{DBD}^{-} \text {Yrm1-myc y pAG413-GAL }}{ }_{\mathrm{UAS}}-\mathrm{lucCP}^{+}\end{array}$ \\
\hline $\begin{array}{l}\text { \gal4-Yrr1- GAL } \\
\text { lucCP }^{+}\end{array}$ & $\begin{array}{l}\text { W303-1A gal4::KANMX4 con pGBKT7-ADH1p- Este trabajo } \\
{\text { Gal4 } \text { DBD }^{-Y r r 1-m y c ~ y ~ p A G 413-G A L ~}}_{\text {UAS-lucCP }}{ }^{+}\end{array}$ \\
\hline $\begin{array}{l}\triangle \text { gal4-Stb5- } \text { GAL }_{\mathrm{UAS}}- \\
\text { lucCP }^{+}\end{array}$ & $\begin{array}{l}\text { W303-1A gal4::KANMX4 con pGBKT7-ADH1p- Este trabajo } \\
\text { Gal4 }_{\mathrm{DBD}^{-}} \text {-Stb5-myc y pAG413-GAL } \mathrm{UAS}^{-} \text {lucCP }^{+}\end{array}$ \\
\hline
\end{tabular}

Tabla suplementaria 5. Plásmidos y construcciones.

\begin{tabular}{|c|c|c|}
\hline Plásmidos & Descripción & Procedencia \\
\hline pUG6-lucCP ${ }^{+}$-CYC1T-KAN & AmpR, loxp-KANMX-loxp & TFG Sandra Saiz \\
\hline pAG413-CYC1 $\Delta$-lucCP ${ }^{+}$ & AmpR, centromérico, HIS3 & Rienzo et al., 2012 \\
\hline pAG413-GRE2-lucCP ${ }^{+}$ & pAG413 con promotor GRE2 & Rienzo et al., 2012 \\
\hline pAG413-SOD2-lucCP ${ }^{+}$ & pAG413 con promotor SOD2 & Dolz-Edo et al., 2013 \\
\hline pAG413-3xAP1-lucCP ${ }^{+}$ & pAG413 con 3 repeticiones del elemento AP1 & Dolz-Edo et al., 2013 \\
\hline pAG413-3xPDRE-lucCP ${ }^{+}$ & pAG413 con 3 repeticiones del elemento PDRE & Este trabajo \\
\hline pAG413-GAL1 UAS $^{-l u c C P}{ }^{+}$ & pAG413 con secuencia GAL1 $1_{\text {UAS }}$ & Este trabajo \\
\hline $\begin{array}{l}\text { pGBKT7-ADH1p-Gal4 } \text { DBD }^{-} \\
\text {myc }\end{array}$ & KanR, TRP1, & $\begin{array}{l}\text { Clontech cedido por } \\
\text { Pascual Sanz }\end{array}$ \\
\hline $\begin{array}{l}\text { pGBKT7-ADH1p-Gal4 } \text { DBD- }^{-} \\
\text {Pdr1-myc }\end{array}$ & pGBKT7 con XBD de Pdr1 & Este trabajo \\
\hline $\begin{array}{l}\text { pGBKT7-ADH1p-Gal4 } \text { DBD- }^{-} \\
\text {Pdr3-myc }\end{array}$ & pGBKT7 con XBD de Pdr3 & Este trabajo \\
\hline $\begin{array}{l}\text { pGBKT7-ADH1p-Gal4 } \text { DBD- }^{-} \\
\text {Pdr8-myc }\end{array}$ & pGBKT7 con XBD de Pdr8 & Este trabajo \\
\hline $\begin{array}{l}\text { pGBKT7-ADH1p-Gal4 }{ }_{\mathrm{DBD}^{-}} \\
\text {Yrm1-myc }\end{array}$ & pGBKT7 con XBD de Yrm1 & Este trabajo \\
\hline $\begin{array}{l}\text { pGBKT7-ADH1p-Gal4 }{ }_{\mathrm{DBD}^{-}} \\
\text {Yrr1-myc }\end{array}$ & pGBKT7 con XBD de Yrr1 & Este trabajo \\
\hline $\begin{array}{l}\text { pGBKT7-ADH1p-Gal4 } \text { DBD- }^{-} \\
\text {Stb5-myc }\end{array}$ & pGBKT7 con XBD de Stb5 & Este trabajo \\
\hline
\end{tabular}

Tabla suplementaria 6. Oligonucleótidos empleados.

\begin{tabular}{ccc}
\hline Nombre & Secuencia 5' $\mathbf{5}^{\prime} \mathbf{3}$ & Descripción \\
\hline LucSeqRev & GGTGATGTCCACCTCAATG & $\begin{array}{c}\text { Comprobación } \\
\text { gen luciferasa }\end{array}$ \\
$\begin{array}{c}\text { PDR5-luc- } \\
\text { KAN1 }\end{array}$ & CTTTTAAGTTTTCGTATCCGCTCGTTCGAAAGACTTTAG & $\begin{array}{c}\text { Inserción lucCP+ } \\
\end{array}$ \\
\hline
\end{tabular}




\begin{tabular}{|c|c|c|}
\hline & ACAAAACCATGGCCGATGCTAAGAAC & en PDR5 \\
\hline $\begin{array}{l}\text { PDR5-luc- } \\
\text { KAN2 }\end{array}$ & $\begin{array}{c}\text { GTCCATCTTGGTAAGTTTCTTTTCTTAACCAAATTCAAA } \\
\text { ATTCTAGCATAGGCCACTAGTGGATCTG }\end{array}$ & $\begin{array}{l}\text { Inserción lucCP+ } \\
\text { en PDR5 }\end{array}$ \\
\hline PDR5-292 & GTGGTACGATATCTGTTGAACG & $\begin{array}{l}\text { Comprobación } \\
\text { inserción }\end{array}$ \\
\hline $\begin{array}{l}\text { SNQ2-luc- } \\
\text { KAN1 }\end{array}$ & $\begin{array}{l}\text { AGTGGATAGAATAACACAGCTACCAAAATACGTAAAGA } \\
\text { GAATTCACCATGGCCGATGCTAAGAAC }\end{array}$ & $\begin{array}{l}\text { Inserción lucCP+ } \\
\text { en SNQ2 }\end{array}$ \\
\hline $\begin{array}{l}\text { SNQ2-luc- } \\
\text { KAN2 }\end{array}$ & $\begin{array}{c}\text { AAAGGCAGATGAATGCACAAAATGTTAAGTTATCTGAA } \\
\text { GCCCACAGCATAGGCCACTAGTGGATCTG }\end{array}$ & $\begin{array}{l}\text { Inserción lucCP+ } \\
\text { en SNQ2 }\end{array}$ \\
\hline SNQ2-273 & CAAGTTGAAGTGTTGCGAGGTC & $\begin{array}{l}\text { Comprobación } \\
\text { inserción }\end{array}$ \\
\hline $\begin{array}{l}\text { PDR15-luc- } \\
\text { KAN1 }\end{array}$ & $\begin{array}{c}\text { ACACACACACACACAAGCAAACACACTTATAATTATCA } \\
\text { AAAACCTCCATGGCCGATGCTAAGAAC }\end{array}$ & $\begin{array}{l}\text { Inserción lucCP+ } \\
\text { en PDR15 }\end{array}$ \\
\hline $\begin{array}{l}\text { PDR15-luc- } \\
\text { KAN2 }\end{array}$ & $\begin{array}{l}\text { TATAATAAAAAGATAATATAACTAAAAAAAAGGAAAAT } \\
\text { AACGTCAGCATAGGCCACTAGTGGATCTG }\end{array}$ & $\begin{array}{l}\text { Inserción lucCP+ } \\
\text { en PDR15 }\end{array}$ \\
\hline PDR15-278 & CTGCTACTGCTGTGCGAGAC & $\begin{array}{l}\text { Comprobación } \\
\text { inserción }\end{array}$ \\
\hline Kan-B & GGATGTATGGGCTAAATG & $\begin{array}{l}\text { Comprobación } \\
\text { gen kanamicina }\end{array}$ \\
\hline $\begin{array}{l}\text { SwitchKanHis } \\
\text { FW }\end{array}$ & $\begin{array}{c}\text { CTTGCTAGGATACAGTTCTCACATCACATCCGAACATAA } \\
\text { ACAACCAGATGACAGAGCAGAAAGCCC }\end{array}$ & Cambio Kan/His \\
\hline $\begin{array}{l}\text { SwitchKanHis } \\
\text { RV }\end{array}$ & $\begin{array}{l}\text { ATGACAAGTTCTTGAAAACAAGAATCTTTTTATTGTCAG } \\
\text { TACTGACACTACATAAGAACACCTTTGG }\end{array}$ & Cambio Kan /His \\
\hline $\begin{array}{l}\text { BspEI-EcoRV- } \\
\text { 3xPdr1T-1 }\end{array}$ & $\begin{array}{l}\text { CCGGCGATATCTCCGTGGATAGAATACATCCGTGGATC } \\
\text { GCGATCATCCGTGGAT }\end{array}$ & $\begin{array}{l}\text { Oligos de } \\
\text { hibridación; } 5 \\
\text { fosforilado }\end{array}$ \\
\hline $\begin{array}{l}\text { BspEI-EcoRV- } \\
\text { 3xPdr1T-2 }\end{array}$ & $\begin{array}{l}\text { CCGGATCCACGGATGATCGCGATCCACGGATGTATTCTA } \\
\text { TCCACGGAGATATCG }\end{array}$ & $\begin{array}{l}\text { Oligos de } \\
\text { hibridación; } 5 \\
\text { fosforilado }\end{array}$ \\
\hline Gal4D1 & $\begin{array}{c}\text { ACGCCATCATTTTAAGAGAGGACAGAGAAGCAAGCCTC } \\
\text { CTGAAAGCAGCTGAAGCTTCGTACGC }\end{array}$ & GAL4 Deletion \\
\hline Gal4D2 & $\begin{array}{l}\text { CAGTTGAAGTGAACTTGCGGGGTTTTTCAGTATCTACGA } \\
\text { TTCATTGCATAGGCCACTAGTGGATCTG }\end{array}$ & GAL4 Deletion \\
\hline Gal4Chk & TTGAGACAGCATTCGCCCAG & $\begin{array}{l}\text { Check GAL4 } \\
\text { Deletion }\end{array}$ \\
\hline Gal4i1 & TTAGCCATTGGAGCCTGGTG & $\begin{array}{l}\text { Check GAL4 } \\
\text { Deletion }\end{array}$ \\
\hline Gal4i2 & GCGATAGTTGCAGAACCGAC & $\begin{array}{l}\text { Check GAL4 } \\
\text { Deletion }\end{array}$ \\
\hline T7fw & TAATACGACTCACTATAGGGC & $\begin{array}{l}\text { Secuenciar } \\
\text { pGBKT7 }\end{array}$ \\
\hline T7rev & CTCAAGACCCGTTTAGAGGC & $\begin{array}{l}\text { Secuenciar } \\
\text { pGBKT7 }\end{array}$ \\
\hline $\begin{array}{l}\text { Gal1UAS- } \\
\text { MunI }\end{array}$ & CCGGCAATTGTGGAAATGTAAAGAGCCCC & $\begin{array}{l}\text { Obtención } \\
\text { fragmento UAS }\end{array}$ \\
\hline $\begin{array}{l}\text { Gal1UAS- } \\
\text { Kpn2I }\end{array}$ & ATCGTCCGGAGCAGTGCGGCGCGAG & $\begin{array}{l}\text { Obtención } \\
\text { fragmento UAS }\end{array}$ \\
\hline PDR1-NcoI-N & CATGCCATGGGTGGCGCTCGAATAAAAAACC & $\begin{array}{l}\text { Fusionar Pdr1 } \\
\text { con Gal4DBD } \\
\text { (pGBKT7) }\end{array}$ \\
\hline
\end{tabular}


Tablas suplementarias

\begin{tabular}{|c|c|c|}
\hline $\begin{array}{c}\text { PDR1-BamHI- } \\
\text { N }\end{array}$ & CATGGATCCAAACGTATACGTTTAACTATCTGG & $\begin{array}{c}\text { Fusionar Pdr1 } \\
\text { con Gal4DBD } \\
\text { (pGBKT7) }\end{array}$ \\
\hline PDR3-NcoI & CATGCCATGGATAGTTCCCAGTCTTTGCC & $\begin{array}{c}\text { Fusionar Pdr3 } \\
\text { con Gal4DBD } \\
\text { (pGBKT7) }\end{array}$ \\
\hline PDR3-BamHI & CATGGATCCGTTTTCATAAGAAGGGATATG & $\begin{array}{c}\text { Fusionar Pdr3 } \\
\text { con Gal4DBD } \\
\text { (pGBKT7) }\end{array}$ \\
\hline YRM1-NcoI & CATGCCATGGAGTTATTTGGCAGTACTCCG & $\begin{array}{c}\text { Fusionar Yrm1 } \\
\text { con Gal4DBD } \\
\text { (pGBKT7) }\end{array}$ \\
\hline YRM1-BamHI & CATGGATCCTCTACTGCGTATCAAATAA & $\begin{array}{l}\text { Fusionar Yrm1 } \\
\text { con Gal4DBD } \\
\text { (pGBKT7) }\end{array}$ \\
\hline YRR1-NcoI & CATGCCATGGAAAAGAAAGCTACCTATGGTCC & $\begin{array}{c}\text { Fusionar Yrr1 } \\
\text { con Gal4DBD } \\
\text { (pGBKT7) }\end{array}$ \\
\hline YRR1-BamHI & CATGGATCCTCGACTTAGCATTAATTGTC & $\begin{array}{c}\text { Fusionar Yrr1 } \\
\text { con Gal4DBD } \\
\text { (pGBKT7) }\end{array}$ \\
\hline PDR8-EcoRI & CATGAATTCGAGCAAGTGCCCAATGTAG & $\begin{array}{c}\text { Fusionar Pdr8 } \\
\text { con Gal4DBD } \\
\text { (pGBKT7) }\end{array}$ \\
\hline PDR8-BamHI & CATGGATCCATGTAAAAAAATACATCAATC & $\begin{array}{c}\text { Fusionar Pdr8 } \\
\text { con Gal4DBD } \\
\text { (pGBKT7) }\end{array}$ \\
\hline STB5-EcoRI & CATGAATTCAAGAAGGAGTTAGCGGATGC & $\begin{array}{c}\text { Fusionar Stb5 } \\
\text { con Gal4DBD } \\
\text { (pGBKT7) }\end{array}$ \\
\hline STB5-BamHI & CATGGATCCTCGGTGAACATATGTCATAC & $\begin{array}{c}\text { Fusionar Stb5 } \\
\text { con Gal4DBD } \\
\text { (pGBKT7) }\end{array}$ \\
\hline
\end{tabular}



ANEXOS 

Article

\title{
Toxicity Mechanisms of the Food Contaminant Citrinin: Application of a Quantitative Yeast Model
}

\author{
Amparo Pascual-Ahuir ${ }^{1, *}$, Elena Vanacloig-Pedros ${ }^{1}$ and Markus Proft ${ }^{2, *}$ \\ 1 Department of Biotechnology, Instituto de Biología Molecular y Celular de Plantas, \\ Universidad Politécnica de Valencia, Ingeniero Fausto Elio s/n, 46022 Valencia, Spain; \\ E-Mail: mevaped@etsia.upv.es
}

2 Department of Mechanisms of Plant Stress Responses, Instituto de Biología Molecular y Celular de Plantas, Consejo Superior de Investigaciones Científicas, Ingeniero Fausto Elio s/n, 46022 Valencia, Spain

* Authors to whom correspondence should be addressed; E-Mails: apascual@ibmcp.upv.es (A.P.-A.); mproft@ibmcp.upv.es (M.P.); Tel.: +34-96-387-9932 (A.P.-A. \& M.P.);

Fax: +34-96-387-7859 (A.P.-A. \& M.P.).

Received: 31 March 2014; in revised form: 5 May 2014 / Accepted: 15 May 2014 /

Published: 22 May 2014

\begin{abstract}
Mycotoxins are important food contaminants and a serious threat for human nutrition. However, in many cases the mechanisms of toxicity for this diverse group of metabolites are poorly understood. Here we apply live cell gene expression reporters in yeast as a quantitative model to unravel the cellular defense mechanisms in response to the mycotoxin citrinin. We find that citrinin triggers a fast and dose dependent activation of stress responsive promoters such as GRE2 or SOD2. More specifically, oxidative stress responsive pathways via the transcription factors Yap1 and Skn7 are critically implied in the response to citrinin. Additionally, genes in various multidrug resistance transport systems are functionally involved in the resistance to citrinin. Our study identifies the antioxidant defense as a major physiological response in the case of citrinin. In general, our results show that the use of live cell gene expression reporters in yeast are a powerful tool to identify toxicity targets and detoxification mechanisms of a broad range of food contaminants relevant for human nutrition.
\end{abstract}

Keywords: citrinin; oxidative stress; yeast; mycotoxins 


\section{Introduction}

Mycotoxins are secondary metabolites produced by many fungi, which represent a major group of hazardous food contaminants [1,2]. Citrinin, (3R,4S)-8-hydroxy-3,4,5-trimethyl-6-oxo-4,6-dihydro$3 \mathrm{H}$-isochromene-7-carboxylic acid, is a well-known mycotoxin, which was first isolated from Penicillium citrinum, but can be produced by many other fungal species belonging to the genera Penicillium, Aspergillus and Monascus [3]. Citrinin is an important contaminant of human foods, such as cereals, cheese or sake. It is also found in red yeast rice, widely used in Asia as a food additive or in the elaboration of wine. Citrinin might be even a more common contaminant all over the world since it can be synthesized by the same molds which produce the globally found mycotoxin ochratoxin A. Although the actual mechanism of citrinin toxicity is not entirely understood, in many toxicological models it has been found to cause nephrotoxicity [4]. Several studies in different cell systems seem to confirm that citrinin can generally cause the production of reactive oxygen species (ROS) [5-9]. Moreover, antioxidants have been shown to alleviate the citrinin toxicity [10,11]. Furthermore, several oxidative stress related genes are up-regulated in response to citrinin in yeast according to transcriptomic experiments [12]. However, it is not clear whether this antioxidant defense in yeast is general or restricted to specific enzymatic functions. A recent study from the European Food Safety Authority [13] preliminarily set the maximal citrinin dose of no concern for nephrotoxicity in humans at an exposure level of $0.2 \mu \mathrm{g} / \mathrm{kg}$ body weight per day. For high consuming individuals, especially children, the critical citrinin concentration ranges between 9 and $53 \mu \mathrm{g} / \mathrm{kg}$ grain-based products and for average consumers between 19 and $100 \mu \mathrm{g} / \mathrm{kg}$ grain-based products. However, the same study concluded that the impact of uncertainties on the risk assessment of citrinin is large, and that more data regarding both the occurrence of citrinin in food and feed in Europe and the toxicity mechanisms of this mycotoxin are needed.

Here, we use a yeast (Saccharomyces cerevisiae) model to study the toxicology of citrinin. A large body of experimental data confirm that yeast cells respond to many different environmental stresses, including toxins, with the transcriptional activation of so called defense genes in order to survive, adapt and eventually resume growth [14]. The basic idea of the system employed here is that measuring the immediate gene expression response can be indicative of the actual toxicity mechanisms of a particular chemical compound. The use of destabilized luciferase as a reporter allows to quantify stress-induced gene expression in a very sensitive and time resolved manner in living yeast cells [15]. The luciferase assay has the additional advantage that many different environmental conditions, such as different toxin concentrations, etc., can be monitored simultaneously. In this way, true dose response patterns are obtained for any toxic compound of interest. The in vivo luciferase assay has been very recently applied to decipher dynamic responses of yeast cells to oxidative and saline stress [16]. In the present study we apply specific luciferase reporter fusions to gain insights into the mode of toxicity of citrinin. We find that citrinin triggers an immediate response to oxidative stress characterized by a strong and dose-dependent induction of natural genes. Furthermore, the oxidative stress responsive transcription factors Yap1 and $\mathrm{Skn} 7$ are critically involved in the adaptive gene expression triggered by citrinin. More specifically, Yap1 dependent artificial luciferase reporters are highly responsive to citrinin. Genetic manipulations which eliminate specific multidrug export systems 
of yeast increase the citrinin toxicity. Altogether the results presented here strongly suggest that oxidative damage might be the prevalent and immediate toxicity mechanism of the mycotoxin citrinin.

\section{Materials and Methods}

\subsection{Yeast Strains and Growth Conditions}

Saccharomyces cerevisiae strains used in this study were: wild type BY4741 (MATa; his341;

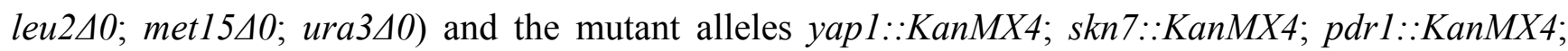
pdr5::KanMX4; snq $2:$ KanMX4. For luciferase assays the cells were transformed with the respective lucCP ${ }^{+}$fusion plasmids and grown in Synthetic Dextrose (SD) medium which contained 0.67\% Yeast Nitrogen Base, 50mM succinic acid pH 5.5, 2\% dextrose, $100 \mathrm{mg} / \mathrm{L}$ methionine, $100 \mathrm{mg} / \mathrm{L}$ leucine and $25 \mathrm{mg} / \mathrm{L}$ uracil. For citrinin sensitivity assays on agar plates, the respective yeast strains were grown in yeast extract-peptone liquid medium containing $2 \%$ dextrose (YPD) to exponential growth phase and then incubated with the indicated concentrations of citrinin.

\subsection{Plasmid Constructions}

The destabilized luciferase reporter fusions with the natural GRE2 or SOD2 promoter are described elsewhere [15,16]. Briefly, the GRE2-lucCP ${ }^{+}$fusion contains the upstream 940 nucleotides of the GRE2 gene fused with the destabilized luciferase $\operatorname{lucCP}^{+}$gene in a centromeric HIS3 containing yeast expression plasmid. The SOD2-lucCP ${ }^{+}$fusion contains the upstream 977 nucleotides of the SOD2 gene in the same vector backbone. The destabilized luciferase reporters with the specific promoter elements STRE, CRE or AP-1 are described in [16]. Briefly, they contain triple insertions of each cis-element in the $C Y C 1$ core promoter fused to $\mathrm{luCP}^{+}$in centromeric HIS3 containing yeast expression plasmids.

\subsection{Live Cell Luciferase Assays}

Yeast strains transformed with the respective luciferase reporter plasmids were grown at $28{ }^{\circ} \mathrm{C}$ overnight in SD medium to $\mathrm{OD}=2$ at $600 \mathrm{~nm}$. The culture volume necessary for the entire luciferase assay was incubated on a roller at $28{ }^{\circ} \mathrm{C}$ for 90 min with $0.5 \mathrm{mM}$ luciferin (Sigma, St. Louis, MO, USA) from a $10 \mathrm{mM}$ stock solution in DMSO. The culture was then distributed in $120 \mu \mathrm{L}$ aliquots in white 96-well plates (Nunc, Penfield, NY, USA) and the indicated concentrations of citrinin were added from a stock solution in DMSO. The mock treated samples contained the same concentration of solvent without the mycotoxin. The light emission from the culture aliquots was continuously recorded in a GloMax Multidetection System (Promega, Madison, WI, USA) in the luminometer mode. Data were normalized for the absolute number of cells used in the assay and processed in Microsoft Excel. For each condition, three independent culture aliquots were analyzed.

\subsection{Yeast Sensitivity Assays}

For plate assays, the yeast strains under study were grown in YPD liquid medium to exponential growth phase. Culture aliquots were then distributed in multiwell plates and exposed for $3 \mathrm{~h}$ to the 
indicated concentrations of citrinin added from a stock solution in DMSO. Equal amounts of cells were then plated on fresh YPD agar plates, which were incubated at $28{ }^{\circ} \mathrm{C}$ for 2 days.

For the Fluorescein Diacetate (FDA) quantification of live cells after acute citrinin exposure, the respective yeast strains were pregrown in liquid YPD medium to exponential growth phase. The amount of cells necessary for the complete assay was washed and resuspended in potassium phosphate (KP) buffer $\left(\mathrm{KH}_{2} \mathrm{PO}_{4} / \mathrm{K}_{2} \mathrm{HPO}_{4} \mathrm{pH}\right.$ 7.4). The indicated doses of citrinin were applied to $120 \mu \mathrm{L}$ cell aliquots in black 96 well plates (Nunc) for $1 \mathrm{~h}$. FDA (Sigma) was added from a $5 \mathrm{mg} / \mathrm{mL}$ stock solution in acetone to a final concentration of $250 \mu \mathrm{g} / \mathrm{mL}$. After $10 \mathrm{~min}$ the fluorescence was quantified in a GloMax Multidetection System (Promega) in the fluorescence mode with excitation at $490 \mathrm{~nm}$ and emission at 510-570 $\mathrm{nm}$. Three independent culture aliquots were measured for each condition. Fluorescence levels were corrected by subtracting the fluorescence produced by the same amount of dead cells, which were obtained by incubation at $80{ }^{\circ} \mathrm{C}$ for $60 \mathrm{~min}$.

\subsection{Statistics}

The luciferase reporter assays were performed with three independent yeast culture aliquots. The standard deviation (SD) in this assay is $<15 \%$; however, error bars are not indicated in the graphs to make the figures clearly visible. For citrinin sensitivity assays, three independent culture aliquots were analyzed. The significance of the differences in the viability among different mutant strains was assessed by the application of the Student's $t$-test.

\section{Results}

We tested whether exposure to the mycotoxin citrinin caused a rapid adaptation of gene expression in yeast. An immediate and transient activation of defense gene expression is a common adaptive response of this organism to a great variety of environmental threats or stresses. Live cell reporters based on the expression of a destabilized luciferase enzyme represent a sensitive method to monitor this adaptive response in real time and upon a gradual range of stress conditions. We first examined a reporter based on a natural yeast promoter (GRE2), which is responsive to different types of stress such as hyperosmotic stress or oxidative stress [17]. As shown in Figure 1, the GRE2-luciferase reporter is readily activated upon acute exposure to citrinin. Robust reporter activation was observed for citrinin doses equal or greater than $100 \mathrm{ppm}$. Importantly the citrinin response of GRE2 was comparable to the activation of the same reporter by salt stress (Figure 1), which is known to trigger a very strong increase of GRE2 expression [16,18]. A dose dependent increase in the luciferase reporter activity was observed in a citrinin concentration range from 100 to $400 \mathrm{ppm}$. Further increases in the toxin dose did not yield a significantly enhanced gene expression response. These results made us confident that the citrinin response of the GRE2-luciferase reporter reflected a biologically meaningful adaptation of yeast to its toxicity, which was further investigated with refined reporter systems.

We next used yeast wild type cells, which were transformed with more specific luciferase reporters, for further citrinin studies. The insertion of multiple copies of just one type of transcription factor binding motif into luciferase expression plasmids, has been shown to create very specific reporters which respond to stimuli via just one or few signal transduction pathways $[15,16]$. Here, we investigated 
three types of cis elements: STRE (bound by the Msn2/4 factors in response to general stress), CRE (bound by the Skol factor in response to osmotic stress and by unknown factors in response to oxidative stress), AP-1 (bound by Yap1 in response to oxidative stress) [16]. As depicted in Figure 2, we found that citrinin exposure activated gene expression from AP-1 and CRE sites, but not from STRE elements. Since yeast AP-1 promoter elements are exclusively activated by oxidative damage, this was a clear indication that citrinin provoked intracellular oxidation, which then activated adaptive gene expression via oxidative stress responsive transcription factors such as Yap1. We further confirmed this by showing that activation of AP1-driven luciferase expression by citrinin was completely absent in a yapl mutant strain (data not shown).

Figure 1. Citrinin activates gene expression from stress responsive yeast promoters in a dose dependent fashion. A fusion of the stress inducible GRE2 promoter with destabilized luciferase was used as a real time reporter for gene expression. Citrinin doses from 100-800 ppm were applied to the yeast cultures. Alternatively the GRE2-luciferase reporter was activated by the indicated concentrations of $\mathrm{NaCl}$. Data shown are mean values from three independent biological samples. $\mathrm{SD}<15 \%$.

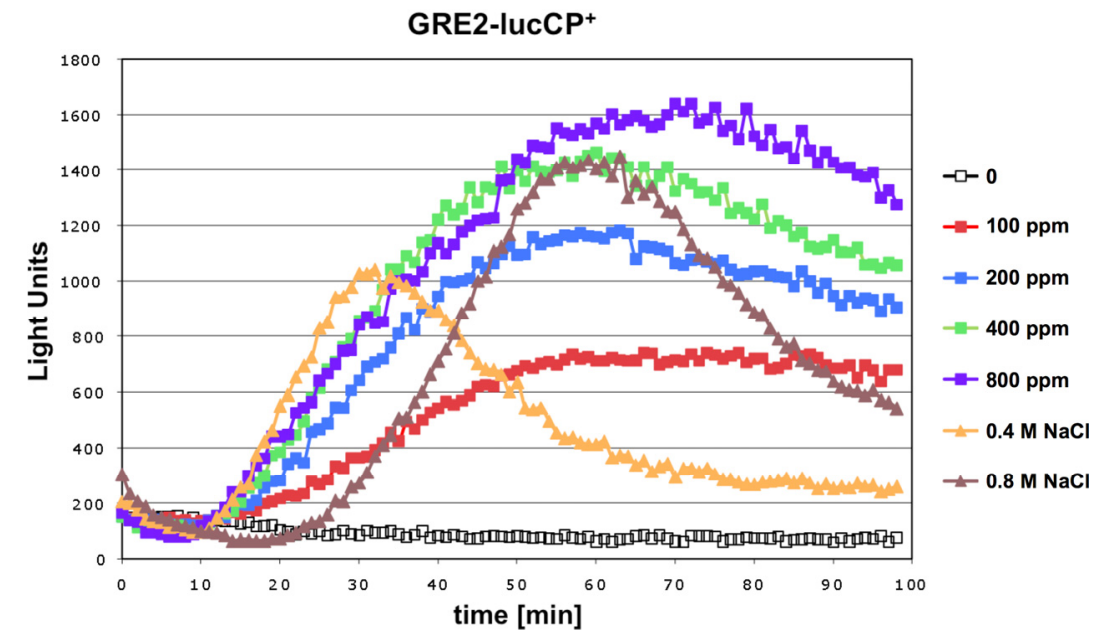

Figure 2. Citrinin activates gene expression from CRE and AP-1 promoter elements in a dose dependent fashion. Artificial promoter-luciferase constructs were used, which contained multiple repetitions of the same cis-element: CRE, AP-1 or STRE as indicated. The indicated citrinin doses were applied at time point 0 to the yeast cultures and the light emission continuously monitored. Data shown are mean values from three independent biological samples. SD $<15 \%$.
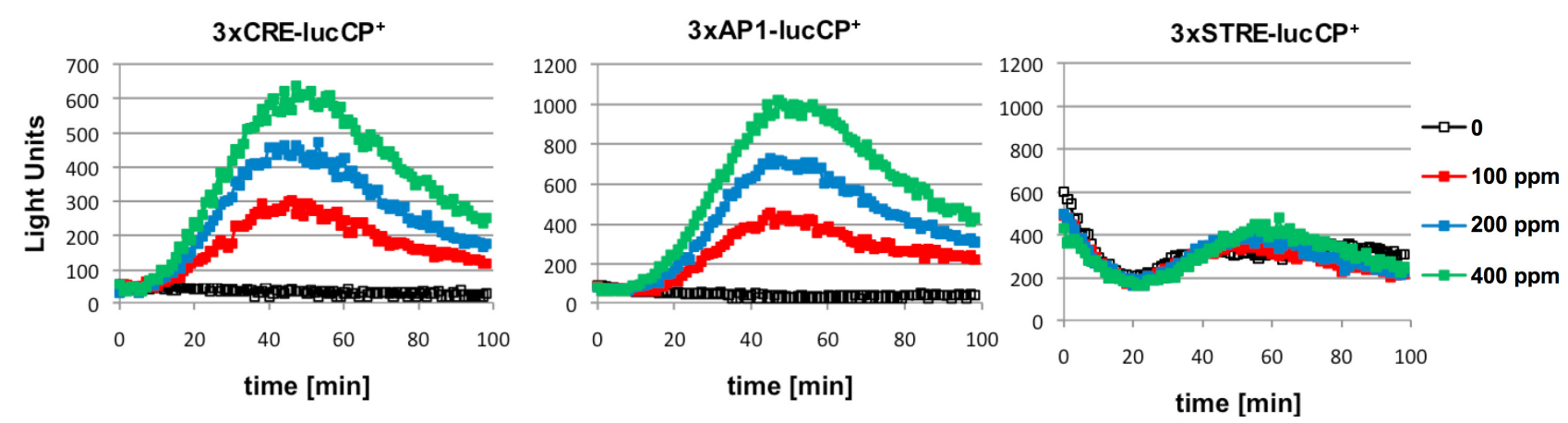
To further investigate the relation between citrinin toxicity and oxidative stress signaling, we monitored the toxin induced gene expression in yeast strains which lacked the activity of the two main transcriptional activators operating upon oxidative stress: Yap1 and Skn7. We used the GRE2-luciferase reporter system to compare the immediate transcriptional upregulation upon citrinin exposure in wild type compared to yapl or skn7 knockout mutants. As shown in Figure 3, in the absence of Yap1 the citrinin induced reporter activity was severely reduced. Yap1 might therefore be one of the main transcriptional regulators which is activated in response to citrinin stress. Skn7 seemed to be additionally involved in the citrinin response; however, its contribution was clearly less important as compared to Yap1 (Figure 3).

Figure 3. Citrinin activates gene expression via the oxidative stress responsive transcription factors Yap1 and Skn7. A fusion of the stress inducible GRE2 promoter with destabilized luciferase was used as a real time reporter for gene expression. The reporter activity was measured in yeast wild type and yapl or $\operatorname{skn} 7$ mutants upon addition of the indicated concentrations of citrinin. Data shown are mean values from three independent biological samples. SD $<15 \%$.

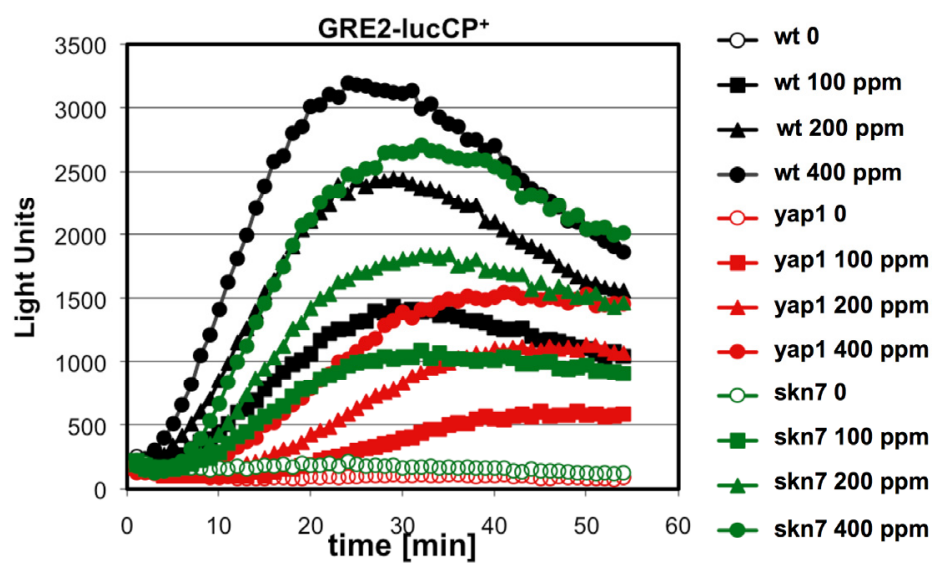

We next wanted to gain insights into the molecular mechanisms of citrinin extrusion and its effect on its toxicitiy. The yeast genome encodes a large family of multidrug transporters which are pleiotropically involved in the export of many xenobiotic chemicals from the cytosol. Two genes of this transporter family, $P D R 5$ and $S N Q 2$, have been identified in yeast as up-regulated upon citrinin exposure [12]. Additionally we included a yeast strain, $\Delta p d r l$, in the citrinin study, which lacks one of the principal transcriptional activators of the multidrug resistance gene family [19]. As shown in Figure 4, the $p d r 5$ mutant strain showed the highest degree of sensitivity to citrinin in a growth assay in rich medium (Figure 4B). The enhanced toxicity of citrinin in a $p d r 5$ mutant was further confirmed by an independent assay using FDA as a live cell stain upon acute citrinin stress in potassium phosphate buffer (Figure 4C). These results indicated that Pdr5 was a major citrinin export activity in yeast and we postulated that $p d r 5$ mutant cells were more sensitive to the mycotoxin because of greater accumulation of citrinin in the cell interior. We therefore measured the adaptive response to citrinin in pdr5 mutants and compared it to wild type. As shown in Figure 4A, the dose dependent response of two citrinin inducible luciferase reporters, GRE2 and SOD2, was largely enhanced in the $p d r 5$ mutant strain. Therefore we can confirm that the lack of the Pdr5 multidrug transporter leads to hypersensitivity 
to citrinin and a more sensitive adaptive response to the toxin, presumably caused by overaccumulation of citrinin inside the cell.

Figure 4. The yeast Pdr5 multidrug transporter is important for the citrinin dose response and sensitivity. (a) Fusions of the stress inducible GRE2 (left panel) or SOD2 (right panel) promoters with destabilized luciferase were used as a real time reporter for gene expression. The reporter activity was measured in yeast wild type and $p d r 5$ mutants upon addition of the indicated concentrations of citrinin. Data shown are mean values from three independent biological samples. SD $<15 \%$; (b) $p d r 5$ mutants show increased sensitivity to citrinin. The indicated citrinin doses were applied to yeast wild type, $p d r 1, p d r 5$ and snq2 mutants for three hours in YPD culture medium. Surviving cells were then assayed on a fresh YPD plate; (c) Yeast wild type and pdr5 mutant cells were incubated for one hour with the indicated amounts of citrinin in KP buffer. The amount of living cells was then quantified by staining with FDA. Data are mean values from three independent biological replicas. Error bars are SD. The asterisks refer to $p<0.05$ different from wt in the same condition according to the Student's $t$-test. The value for mock treated cells was arbitrarily set to 100 for both yeast strains.
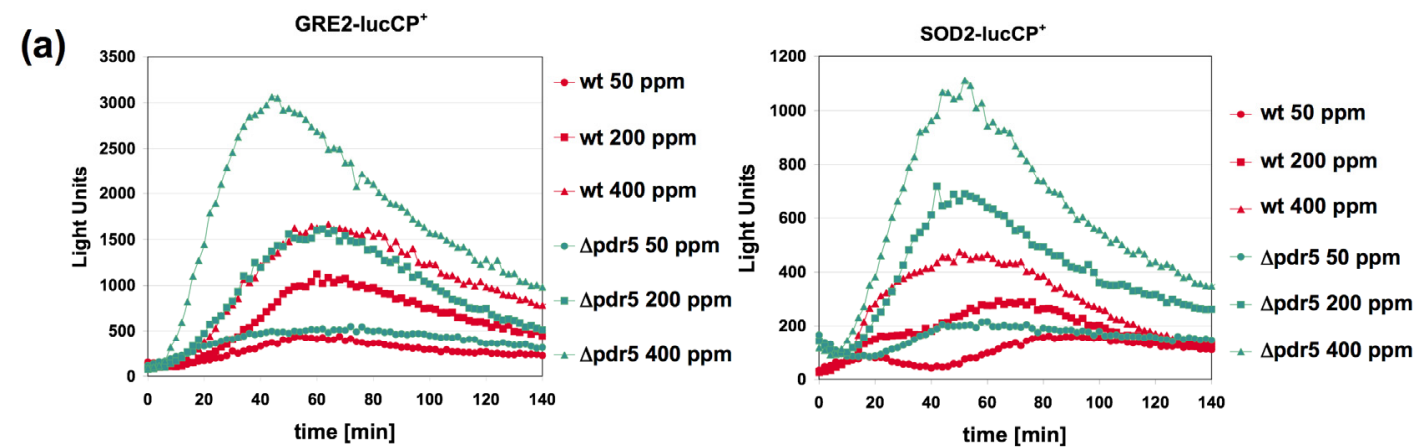

(b)

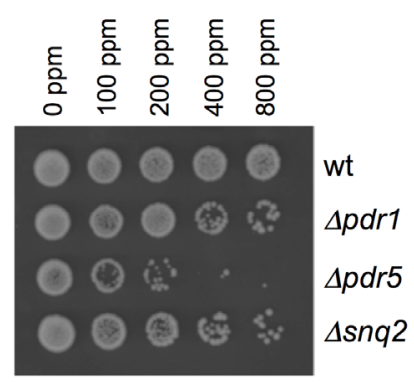

(c)

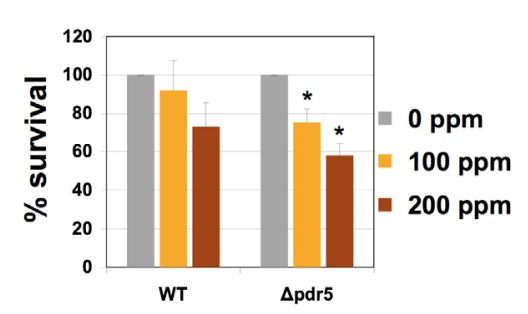

\section{Discussion}

Citrinin is an important food contaminant produced by Penicillium, Aspergillus and Monascus species. Although it is generally classified as a nephrotoxic compound, its principle mechanisms of toxicity are not entirely clear. Various in vitro studies have determined different possible pathways and sources of cellular damage including lipid peroxidation, mitochondrial dysfunction or the induction of apoptotic cell death [5,20-22]. Additionally, genotoxic effects of citrinin have been confirmed by the enhanced formation of micronuclei in different animal and human cell lines [23-26]. However, the primary mechanisms of citrinin toxicity remain elusive. In the present study we use a yeast based reporter system to gain insights into the immediate cellular response to the exposure to citrinin. Yeast 
cells are an excellent cellular model to study the adaptive response to diverse chemical threats, since these unicellular organisms have evolved efficient detoxification paths, which assure cell survival and are often triggered by rapid transcriptional activation of defense systems. Moreover, the application of live cell reporter assays enables to monitor the dose sensitive stress response in a small aliquot of living yeast cells in real time $[15,16]$. Application of this monitoring method clearly shows that citrinin triggers an immediate adaptive response related to the oxidative stress defense. Citrinin provokes the rapid up-regulation of oxidative stress responsive genes such as GRE2 or SOD2. Of note, the mitochondrial enzyme superoxide dismutase encoded by SOD2 has a well defined antioxidant function upon sudden bursts of reactive oxygen species (ROS) [27]. Therefore, one of the primary and immediate toxic effects of citrinin is very likely the generation of high ROS levels, which are targeted by the yeast cell by the activation of enzymatic antioxidants. Several lines of evidence indicate that citrinin induced ROS levels must be a critical determinant of the toxicity of this mycotoxin: a- citrinin induces the expression of the GRE2 or SOD2 genes to levels which are comparable to their most potent natural inducers such as $\mathrm{NaCl}$ or hydrogen peroxide [16]; b- transcriptional regulators specifically involved in the yeast antioxidant response, such as Yap1 or Skn7, are important for the efficient activation of gene expression upon citrinin treatment; c- the dose sensitive transcriptional activation triggered by citrinin $(50-400 \mathrm{ppm} ; 0.2-1.6 \mathrm{mM})$ occurs in a similar concentration range as compared to hydrogen peroxide $(0.1-1.0 \mathrm{mM})$ [16].

Our data are in agreement with transcriptomic surveys performed in yeast upon citrinin stress, which identified some antioxidant functions to be up-regulated in response to the mycotoxin [12]. Iwahashi and coworkers identified a limited number of genes with a confirmed or presumed function in the oxidative stress response including some $A A D$ genes (hypothetical aryl-alcohol dehydrogenases), OYE3 (NADPH oxidoreductase), GRE2 (methylglyoxal reductase), and TRX2 (thioredoxin) [12]. However, it was important to prove whether citrinin triggers a general antioxidant response in cells. This is confirmed by our study here by the use of oxidative stress specific reporter genes. The most direct proof that citrinin primarily causes intracellular oxidation is the robust activation of a reporter gene controlled by the AP-1 promoter element, which is known to be selectively and exclusively activated by increases in intracellular ROS via the Yap1 transcription factor [16,28,29]. Of note, citrinin causes an immediate activation of oxidative stress specific reporter genes very similar to well known and potent pro-oxidants such as hydrogen peroxide or menadione [8]. Additionally the antioxidant response is observed here in glucose containing growth medium, which is a fermentative condition repressing mitochondrial energy metabolism in yeast. These facts indicate that citrinin directly damages cellular components different from mitochondria. Our data obtained in the yeast model confirm previous reports in higher cell lines demonstrating that citrinin is able to trigger oxidative stress [5-9]. This is important because a possible antioxidant function has been proposed for citrinin, which does not seem to be relevant in vivo and might be attributable to specific chemical derivatives of this mycotoxin [30].

Yeast cells seem to be inherently more resistant to citrinin as compared to higher eukaryotic cell lines. In our hands, a yeast wild type begins to mount a measurable gene expression response at citrinin doses around $50 \mathrm{ppm}(200 \mu \mathrm{M})$ and easily survives treatments as high as $200 \mathrm{ppm}(800 \mu \mathrm{M})$. Mammalian cell cultures show significant genotoxic damage and loss of viability already at citrinin concentrations of approximately $50 \mu \mathrm{M}$ [24]. An important part of the observed citrinin 
tolerance is likely the efficient extrusion of the toxin from the interior of the yeast cell. Iwahashi and coworkers identified two multidrug resistance transporter encoding genes to be up-regulated upon citrinin exposure [12]. According to our results, one of them (Pdr5), is especially important for citrinin tolerance. Yeast cells lacking Pdr5 are hypersensitive to citrinin and trigger a greater adaptive response to the toxin presumably because this strain accumulates citrinin to higher intracellular levels. An additional barrier for citrinin toxicity might also be the yeast cell wall. The outer envelope together with efficient efflux systems might therefore make yeast cells more resistant to citrinin and shift their transcriptional response to doses which are higher than normally found in contaminated food. Taken together, our study demonstrates that yeast serves as an efficient model to unravel toxicity mechanisms and detoxification strategies upon exposure to human food contaminants such as mycotoxins.

\section{Conclusions}

The mycotoxin citrinin triggers an immediate and general antioxidant response in yeast cells. Induction of harmful ROS levels might therefore be the prevalent toxicity mechanism of this toxin. In yeast cells, citrinin activates the expression of antioxidant encoding genes and oxidative stress specific reporters. The ROS activated transcription factor Yap1 is critically involved in the adaptive response to citrinin. Additionally, the mutation of specific toxin exporters such as Pdr5, identifies physologically important citrinin defense systems. Yeast is an efficient model to unravel toxicity and detoxification mechanisms of mycotoxins.

\section{Acknowledgments}

This work was supported by Ministerio de Economía y Competitividad grant BFU2011-23326. We thank the Fond for Open Access Publication from Consejo Superior de Investigaciones Científicas for supporting publication costs of this article.

\section{Author Contributions}

A.P.-A. and E.V.-P. performed the experimental work; all authors analysed data or performed statistical analysis; A.P.-A. and M.P. wrote the manuscript; all authors had responsibility for the final content.

\section{Conflicts of Interest}

The authors declare no conflict of interest.

\section{References}

1. Moretti, A.; Susca, A.; Mule, G.; Logrieco, A.F.; Proctor, R.H. Molecular biodiversity of mycotoxigenic fungi that threaten food safety. Int. J. Food Microbiol. 2013, 167, 57-66.

2. Wu, F.; Groopman, J.D.; Pestka, J.J. Public health impacts of foodborne mycotoxins. Annu. Rev. Food Sci. Technol. 2014, 5, 351-372.

3. Bennett, J.W.; Klich, M. Mycotoxins. Clin. Microbiol. Rev. 2003, 16, 497-516. 
4. Flajs, D.; Peraica, M. Toxicological properties of citrinin. Arh. Hig. Rada. Toksikol. 2009, 60, 457-464.

5. Bouslimi, A.; Ouannes, Z.; Golli, E.E.; Bouaziz, C.; Hassen, W.; Bacha, H. Cytotoxicity and oxidative damage in kidney cells exposed to the mycotoxins ochratoxin a and citrinin: Individual and combined effects. Toxicol. Mech. Methods 2008, 18, 341-349.

6. El Golli, E.; Hassen, W.; Bouslimi, A.; Bouaziz, C.; Ladjimi, M.M.; Bacha, H. Induction of Hsp 70 in Vero cells in response to mycotoxins cytoprotection by sub-lethal heat shock and by vitamin E. Toxicol. Lett. 2006, 166, 122-130.

7. Kumar, R.; Dwivedi, P.D.; Dhawan, A.; Das, M.; Ansari, K.M. Citrinin-generated reactive oxygen species cause cell cycle arrest leading to apoptosis via the intrinsic mitochondrial pathway in mouse skin. Toxicol. Sci. 2011, 122, 557-566.

8. Ribeiro, S.M.; Chagas, G.M.; Campello, A.P.; Kluppel, M.L. Mechanism of citrinin-induced dysfunction of mitochondria. V. Effect on the homeostasis of the reactive oxygen species. Cell Biochem. Funct. 1997, 15, 203-209.

9. Singh, N.D.; Sharma, A.K.; Dwivedi, P.; Leishangthem, G.D.; Rahman, S.; Reddy, J.; Kumar, M. Effect on feeding graded doses of citrinin on apoptosis and oxidative stress in male Wistar rats till F1 generation. Toxicol. Ind. Health 2013, in press.

10. Chen, C.C.; Chan, W.H. Inhibition of citrinin-induced apoptotic biochemical signaling in human hepatoma G2 cells by resveratrol. Int. J. Mol. Sci. 2009, 10, 3338-3357.

11. Hsu, L.C.; Hsu, Y.W.; Liang, Y.H.; Lin, Z.H.; Kuo, Y.H.; Pan, T.M. Protective effect of deferricoprogen isolated from Monascus purpureus NTU 568 on citrinin-induced apoptosis in HEK-293 cells. J. Agric. Food Chem. 2012, 60, 7880-7885.

12. Iwahashi, H.; Kitagawa, E.; Suzuki, Y.; Ueda, Y.; Ishizawa, Y.H.; Nobumasa, H.; Kuboki, Y.; Hosoda, H.; Iwahashi, Y. Evaluation of toxicity of the mycotoxin citrinin using yeast ORF DNA microarray and Oligo DNA microarray. BMC Genomics 2007, 8, doi:10.1186/1471-2164-8-95.

13. European Food Safety Authority (EFSA); Panel on contaminants in the food chain (CONTAM). Scientific Opinion on the risks for public and animal health related to the presence of citrinin in food and feed. EFSA J. 2012, 10, doi:10.2903/j.efsa.2012.2605.

14. Dos Santos, S.C.; Teixeira, M.C.; Cabrito, T.R.; Sa-Correia, I. Yeast toxicogenomics: Genome-wide responses to chemical stresses with impact in environmental health, pharmacology, and biotechnology. Front. Genet. 2012, 3, doi:10.3389/fgene.2012.00063.

15. Rienzo, A.; Pascual-Ahuir, A.; Proft, M. The use of a real-time luciferase assay to quantify gene expression dynamics in the living yeast cell. Yeast 2012, 29, 219-231.

16. Dolz-Edo, L.; Rienzo, A.; Poveda-Huertes, D.; Pascual-Ahuir, A.; Proft, M. Deciphering dynamic dose responses of natural promoters and single cis elements upon osmotic and oxidative stress in yeast. Mol. Cell. Biol. 2013, 33, 2228-2240.

17. Garay-Arroyo, A.; Covarrubias, A.A. Three genes whose expression is induced by stress in Saccharomyces cerevisiae. Yeast 1999, 15, 879-892.

18. Proft, M.; Pascual-Ahuir, A.; de Nadal, E.; Arino, J.; Serrano, R.; Posas, F. Regulation of the Sko1 transcriptional repressor by the Hog1 MAP kinase in response to osmotic stress. EMBO J. 2001, 20, 1123-1133. 
19. Mamnun, Y.M.; Pandjaitan, R.; Mahe, Y.; Delahodde, A.; Kuchler, K. The yeast zinc finger regulators Pdr1p and Pdr3p control pleiotropic drug resistance (PDR) as homo- and heterodimers in vivo. Mol. Microbiol. 2002, 46, 1429-1440.

20. Chagas, G.M.; Campello, A.P.; Kluppel, M.L. Mechanism of citrinin-induced dysfunction of mitochondria. I. Effects on respiration, enzyme activities and membrane potential of renal cortical mitochondria. J. Appl. Toxicol. 1992, 12, 123-129.

21. Klaric, M.S.; Zeljezic, D.; Rumora, L.; Peraica, M.; Pepeljnjak, S.; Domijan, A.M. A potential role of calcium in apoptosis and aberrant chromatin forms in porcine kidney PK15 cells induced by individual and combined ochratoxin A and citrinin. Arch. Toxicol. 2012, 86, 97-107.

22. Yu, F.Y.; Liao, Y.C.; Chang, C.H.; Liu, B.H. Citrinin induces apoptosis in HL-60 cells via activation of the mitochondrial pathway. Toxicol. Lett. 2006, 161, 143-151.

23. Donmez-Altuntas, H.; Dumlupinar, G.; Imamoglu, N.; Hamurcu, Z.; Liman, B.C. Effects of the mycotoxin citrinin on micronucleus formation in a cytokinesis-block genotoxicity assay in cultured human lymphocytes. J. Appl. Toxicol. 2007, 27, 337-341.

24. Follmann, W.; Behm, C.; Degen, G.H. Toxicity of the mycotoxin citrinin and its metabolite dihydrocitrinone and of mixtures of citrinin and ochratoxin A in vitro. Arch. Toxicol. 2014, 88, 1097-1107.

25. Knasmuller, S.; Cavin, C.; Chakraborty, A.; Darroudi, F.; Majer, B.J.; Huber, W.W.; Ehrlich, V.A. Structurally related mycotoxins ochratoxin A, ochratoxin B, and citrinin differ in their genotoxic activities and in their mode of action in human-derived liver (HepG2) cells: Implications for risk assessment. Nutr. Cancer 2004, 50, 190-197.

26. Thust, R.; Kneist, S. Activity of citrinin metabolized by rat and human microsome fractions in clastogenicity and SCE assays on Chinese hamster V79-E cells. Mutat. Res. 1979, 67, 321-330.

27. Van Loon, A.P.; Pesold-Hurt, B.; Schatz, G. A yeast mutant lacking mitochondrial manganese-superoxide dismutase is hypersensitive to oxygen. Proc. Natl. Acad. Sci. USA 1986, 83, 3820-3824.

28. Delaunay, A.; Isnard, A.D.; Toledano, M.B. H2O2 sensing through oxidation of the Yap1 transcription factor. EMBO J. 2000, 19, 5157-5166.

29. Toone, W.M.; Morgan, B.A.; Jones, N. Redox control of AP-1-like factors in yeast and beyond. Oncogene 2001, 20, 2336-2346.

30. Heider, E.M.; Harper, J.K.; Grant, D.M.; Hoffman, A.; Dugan, F.; Tomer, D.P.; O’Neill, K.L. Exploring unusual antioxidant activity in a benzoic acid derivative: A proposed mechanism for citrinin. Tetrahedron 2006, 62, 1199-1208.

(C) 2014 by the authors; licensee MDPI, Basel, Switzerland. This article is an open access article distributed under the terms and conditions of the Creative Commons Attribution license (http://creativecommons.org/licenses/by/3.0/). 
Article

\title{
Different Toxicity Mechanisms for Citrinin and Ochratoxin A Revealed by Transcriptomic Analysis in Yeast
}

\author{
Elena Vanacloig-Pedros ${ }^{1}$, Markus Proft ${ }^{2, *}$ and Amparo Pascual-Ahuir ${ }^{1, *}$ \\ 1 Department of Biotechnology, Instituto de Biología Molecular y Celular de Plantas, \\ Universidad Politécnica de Valencia, Ingeniero Fausto Elio s/n, 46022 Valencia, Spain; mevaped@etsia.upv.es \\ 2 Department of Molecular and Cellular Pathology and Therapy, \\ Instituto de Biomedicina de Valencia IBV-CSIC, Jaime Roig 11, 46010 Valencia, Spain \\ * Correspondence: mproft@ibv.csic.es (M.P.); apascual@ibmcp.upv.es (A.P.-A.); \\ Tel.: +34-96-3391760 (M.P.); +34-96-3877770 (A.P.-A.)
}

Academic Editor: Paola Battilani

Received: 27 July 2016; Accepted: 17 September 2016; Published: 22 September 2016

\begin{abstract}
Citrinin (CIT) and ochratoxin A (OTA) are important mycotoxins, which frequently co-contaminate foodstuff. In order to assess the toxicologic threat posed by the two mycotoxins separately or in combination, their biological effects were studied here using genomic transcription profiling and specific live cell gene expression reporters in yeast cells. Both CIT and OTA cause highly transient transcriptional activation of different stress genes, which is greatly enhanced by the disruption of the multidrug exporter Pdr5. Therefore, we performed genome-wide transcription profiling experiments with the $p d r 5$ mutant in response to acute CIT, OTA, or combined CIT/OTA exposure. We found that CIT and OTA activate divergent and largely nonoverlapping gene sets in yeast. CIT mainly caused the rapid induction of antioxidant and drug extrusion-related gene functions, while OTA mainly deregulated developmental genes related with yeast sporulation and sexual reproduction, having only a minor effect on the antioxidant response. The simultaneous exposure to CIT and OTA gave rise to a genomic response, which combined the specific features of the separated mycotoxin treatments. The application of stress-specific mutants and reporter gene fusions further confirmed that both mycotoxins have divergent biological effects in cells. Our results indicate that CIT exposure causes a strong oxidative stress, which triggers a massive transcriptional antioxidant and drug extrusion response, while OTA mainly deregulates developmental genes and only marginally induces the antioxidant defense.
\end{abstract}

Keywords: Ochratoxin A; Citrinin; Transcriptome; Saccharomyces cerevisiae; mycotoxins; oxidative stress; dose response

\section{Introduction}

Mycotoxins are small toxic molecules produced by a great variety of microorganism, which encompass several classes of secondary metabolites with no common chemical structure or mode of action [1]. These harmful natural products of molds contaminate food and feed worldwide with appalling economic consequences, since they affect most of the staple food crops such as maize, wheat and rice [2,3]. Beyond the economic losses, mycotoxins have a severe impact on human wellbeing [4]. Their toxicological properties and possible health effects have been extensively studied and related to some diseases, although it is certainly difficult to demonstrate the link between toxin exposure and the onset of symptoms in most cases. Mycotoxins are released by some fungi in nature for unclear reasons, and although it is widely accepted that the synthesis and secretion of toxins mediate pathogen virulence of microorganisms in plants, the molecular targets and strategies to achieve it remain to be 
determined in the case of mycotoxins [5]. Considerable efforts have been made to comprehend the molecular mechanisms of mycotoxins to cause cell damage and toxicity [6-8]. Although it is desirable to understand the molecular basis of mycotoxin action in whole animals, these approaches are often difficult because the dose-effect relation depends on many different parameters [7]. As an alternative, the fundamental modes of toxicity for individual mycotoxins can be efficiently revealed in cell cultures of lower eukaryotic cells such as yeast.

Ochratoxins are a small group of mycotoxins produced by Aspergillus and Penicillium species, with ochratoxin A (OTA) as the principal compound, found in a very wide range of raw and processed food [9]. OTA is nephrotoxic, carcinogenic, and a potent teratogen when tested in different mammalian models, and thereby is a potential risk to human health [10]. Several authors support that the mode of action of OTA implies the formation of covalent DNA adducts [11-13] and the increase of reactive oxygen species $[14,15]$, hence these activities could explain the genotoxic and mutagenic activity of OTA. The co-occurrence of OTA with citrinin (CIT), another mycotoxin, has been often reported [16,17]. CIT is produced by filamentous fungi of the genera Penicillium, Aspergillus and Monascus, and contaminates the same staple foodstuffs as OTA [18]. Fungi such as Penicillium verrucosum are able to produce both OTA and CIT, however, different environmental conditions might favor the production of one mycotoxin over the other [19-21]. Much less is known about the toxicity mechanisms of CIT, however, it has been shown to be an efficient nephrotoxin as well [22]. Several groups have contributed to the identification of possible molecular mechanisms of CIT toxicity, finding, among other consequences, the increase of oxidative stress in connection with alterations of mitochondrial function, and induction of apoptosis [23-31]. It has been proposed that the co-occurrence of both toxins results in synergetic effects, however no clear conclusions have been reached [32,33].

Gene expression analysis has become a valuable tool to decipher molecular mechanisms in response to toxic agents, including mycotoxins [34], and the yeast model is particularly important in toxicogenomic studies [35]. Recent transcriptomic approaches with OTA have been performed using different cell lines and mammalian model systems [36-39]. A comparison of the genomic data does not yield a uniform pattern of deregulated genes, and it is striking that DNA damage response genes are not generally highlighted by these omics approaches [40]. It seems that the variability of the OTA-induced transcriptomic response might be a consequence of the range of experimental conditions as well as the cellular context [40]. In contrast to OTA, genomic profiling data for CIT treatment are scarce, however, the application of yeast microarray approaches has identified the antioxidant defense as one of the primordial manners of detoxification upon CIT exposure [41]. The transcriptional response to mycotoxins is likely to be transient and dose dependent, therefore any transcriptomic assay is further complicated by the selection of the optimal induction conditions. Actually, in vivo recording of transcriptional activity in Saccharomyces cerevisiae shows a transient dose-time dependent response to CIT treatment [28].

Given that OTA and CIT are co-occurring toxicological threats in the food chain and that both overlapping and divergent mechanisms of toxicity have been proposed for both mycotoxins, we aim here to compare the immediate transcriptomic response to OTA and CIT, applied either separately or simultaneously. We use an optimized yeast system, where the optimal time point and dose for each mycotoxin has been adjusted according to live cell gene expression reporters and where the signal intensity has been largely increased due to the deletion of the principal toxin exporter Pdr5. We identify largely exclusive patterns of gene deregulation for CIT and OTA, with oxidative stress defense genes specifically activated by CIT and cell differentiation and developmental genes specifically activated by OTA. 


\section{Results}

\subsection{Gene Expression Profiles of Stress Response Genes upon CIT and OTA Exposure}

We have previously shown that live cell reporter fusions in yeast are valuable and quantitative tools to characterize the acute transcriptional adaptation to CIT [28]. Here, we extend these studies to compare the impact of CIT and OTA on the induction of different stress-inducible genes. We used fusions of the oxidative stress-inducible SOD2 (mitochondrial manganese superoxide dismutase) promoter and the general stress-inducible GRE2 (methylglyoxal reductase) promoter with destabilized luciferase as sensitive live cell reporters. Dose-dependent analyses revealed a transient gene expression profile for both reporter genes, upon treatment with CIT and OTA (Figure 1A). Both mycotoxins induced gene expression very rapidly within minutes, indicating that CIT and OTA are readily taken up by yeast cells. However, CIT caused a much broader transcriptional induction, which continuously increased with dose even beyond $400 \mathrm{ppm}(1600 \mu \mathrm{M})$. OTA, in contrast, induced the stress-responsive reporters in a much more transient manner and to much lower absolute induction levels. Moreover, OTA-induced transcription of GRE2 or SOD2 was already maximal at concentrations around $200 \mathrm{ppm}$ $(497 \mu \mathrm{M})$. We next tested the effect of the loss of Pdr5 function, which is a plasma membrane multidrug transporter critically involved in CIT extrusion [28]. As shown in Figure 1B, the deletion of Pdr5 provokes an enhanced transcriptional response to both CIT and OTA treatment at different doses. We next wanted to study the level of synergy involved in the response to CIT and OTA using the same live cell gene expression reporters. Surprisingly, no evident synergistic effect on gene expression was revealed when both toxins were combined together, both in the wild type or the sensitized pdr5 mutant strain (Figure 1C). Taken together, these results indicated that CIT and OTA had differential and independent effects on the induction of stress reporters in yeast. Thus we aimed at studying the differential induction of gene expression upon CIT and OTA exposure at the genomic level. 
A

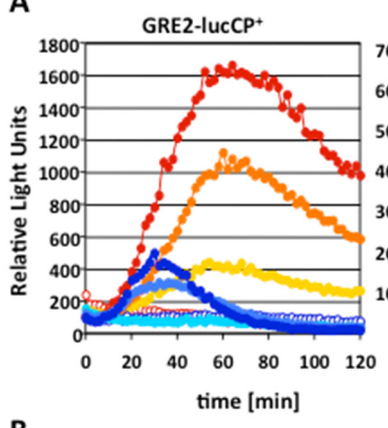

B
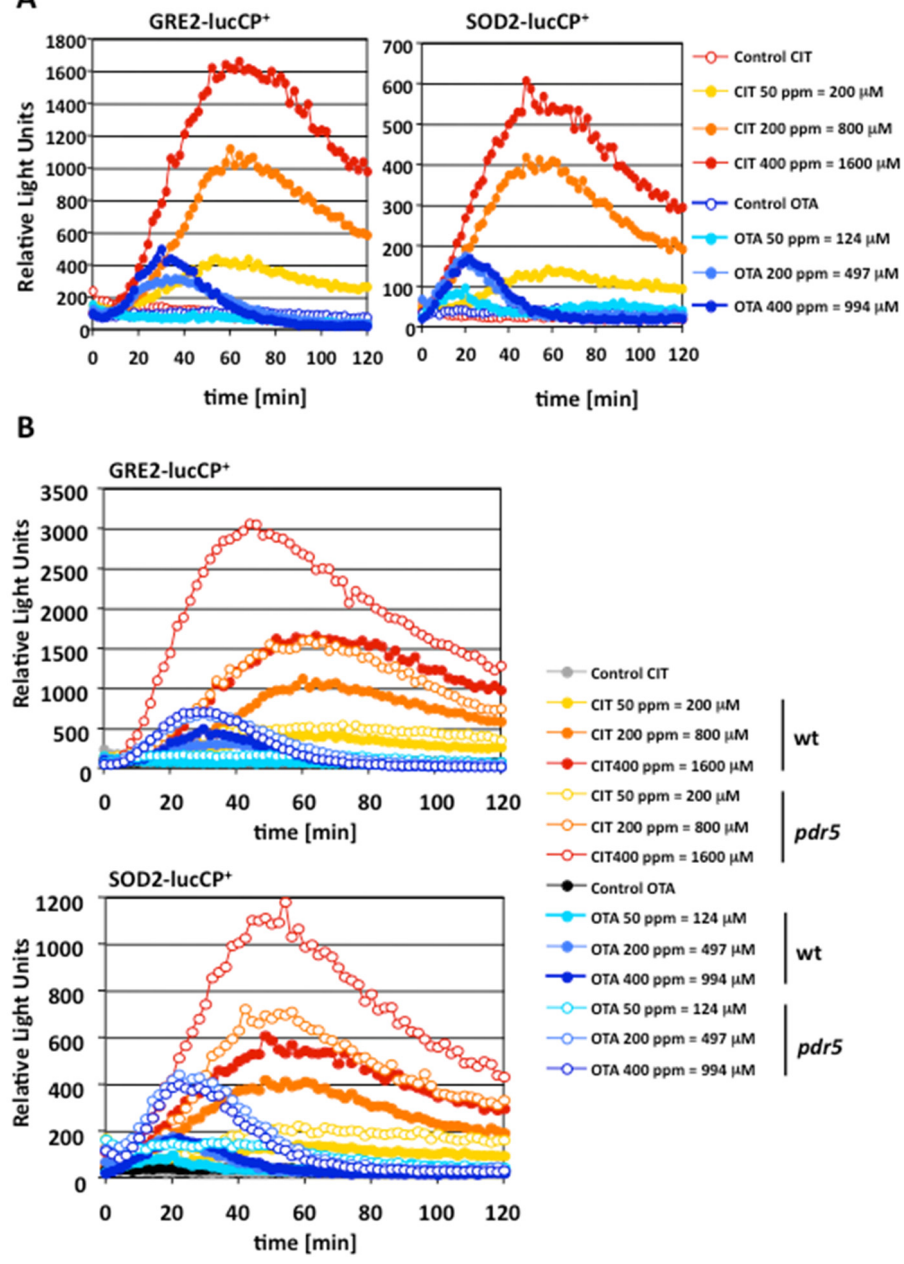

- Control CIr

$-\mathrm{CIT} 50 \mathrm{ppm}=200 \mu \mathrm{M}$

- CIT 200 ppm = $800 \mu \mathrm{M} \quad$ wt

$\rightarrow$ CIT400 ppm = $1600 \mu \mathrm{M}$

CIT $50 \mathrm{ppm}=200 \mu \mathrm{M}$ \begin{tabular}{l|l}
$-O-C I T 200 \mathrm{ppm}=800 \mu \mathrm{M}$ & pdr5 \\
$-O-\mathrm{CIT} 400 \mathrm{ppm}=1600 \mu \mathrm{M}$ &
\end{tabular}

$\rightarrow$ Control OTA

$\because$ OTA 50 ppm $=124 \mu \mathrm{M}$

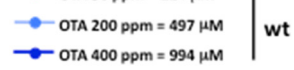

$-O$ OTA 50 ppm $=124 \mu \mathrm{M}$

\begin{tabular}{l|l}
$\multimap$ & - OTA 200 ppm $=497 \mu \mathrm{M}$ \\
$\multimap$ & pdr5
\end{tabular}
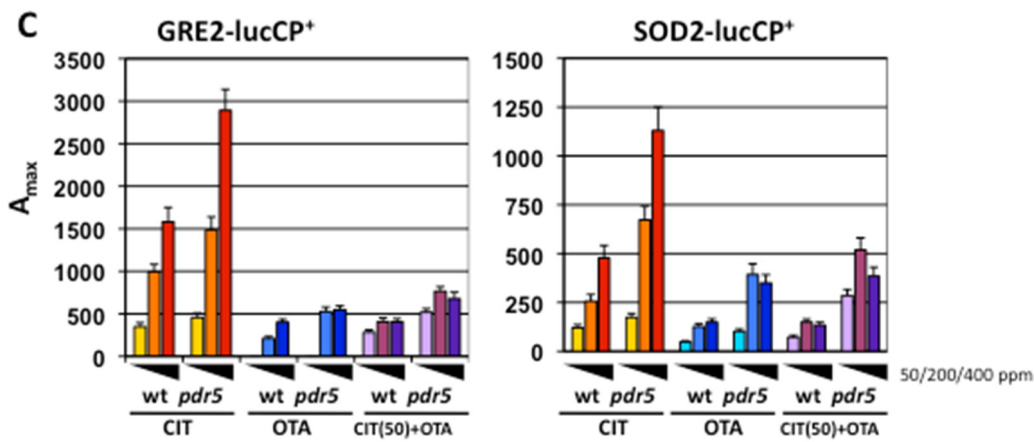

Figure 1. Ochratoxin A (OTA) and citrinin (CIT) activate stress gene expression independently and with different dose response profiles. (A) OTA and CIT induction of the stress-activated genes GRE2 (methylglyoxal reductase) and SOD2 (superoxide dismutase). Live cell reporter fusions with destabilized luciferase were used in yeast wild type cells and the induction of both genes was measured in real time upon the indicated mycotoxin doses. (B) The deletion of the Pdr5 multidrug exporter increases the transcriptional response to both OTA and CIT. The expression profiles for the GRE2 and SOD2 genes are compared for wild type and the pdr5 deletion mutant upon the indicated mycotoxin doses. (C) OTA and CIT do not activate stress gene expression in a synergistic manner. The dose response profiles of $(\mathbf{A})$ and $(\mathbf{B})$ are represented here as the maximal activity $\left(\mathrm{A}_{\max }\right)$ for each mycotoxin dose. Additionally (purple columns at the right of each plot), a constant concentration of CIT $(50 \mathrm{ppm}=200 \mu \mathrm{M})$ was combined with growing concentrations of OTA (50 ppm $=124 \mu \mathrm{M}$; $200 \mathrm{ppm}=497 \mu \mathrm{M} ; 400 \mathrm{ppm}=994 \mu \mathrm{M})$ as indicated. All gene expression experiments were performed on three independent culture aliquots; the Standard Deviation was $<15 \%$; error bars are not included in the graphs in order to make the figure clearly visible. 


\subsection{Genomic Expression Profiles upon Separated and Combined Exposure to CIT and OTA}

Our previous study of specific stress promoters suggested that CIT and OTA had a different impact on gene expression. Both mycotoxins, however, activate gene transcription in a very transient manner. We wanted to take advantage of genome-wide transcription analysis in yeast to gain insights into the differential induction of gene expression triggered by the two mycotoxins. The microarray experiments were performed in the sensitized $p d r 5$ mutant strain and at optimized toxin concentrations and exposure times as revealed by our real time surveys upon acute CIT and OTA exposure. The transcriptomic response of yeast was determined by microarray hybridization upon separated CIT and OTA exposure (200 ppm) as well as upon the combined addition of CIT/OTA (100 ppm each). As a first approach, we identified and ranked the most upregulated genes for each toxin treatment. We applied a very stringent cutoff value and considered only the genes which were expressed more than 5-fold higher in the treated cells as compared to the untreated cells. The resulting gene lists are represented in Table 1 for CIT, in Table 2 for OTA, and in Table 3 for the combined CIT/OTA treatment.

Table 1. Genes > 5-fold upregulated upon CIT (citrinin) exposure.

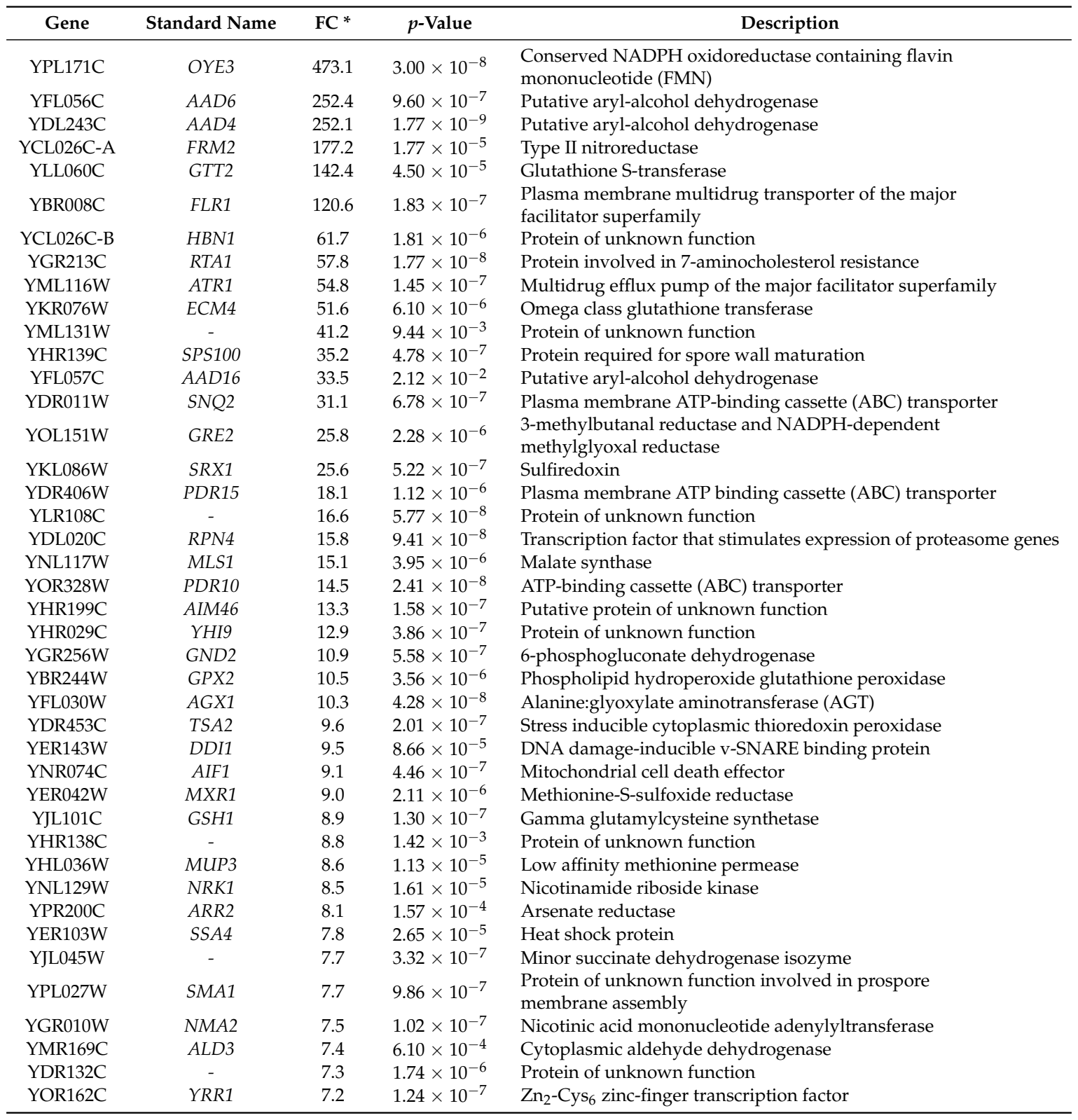


Table 1. Cont

\begin{tabular}{|c|c|c|c|c|}
\hline Gene & Standard Name & FC * & $p$-Value & Description \\
\hline YMR038C & CCS1 & 6.9 & $6.96 \times 10^{-5}$ & Copper chaperone for superoxide dismutase Sod1p \\
\hline YJL219W & HХT9 & 6.9 & $1.67 \times 10^{-7}$ & Putative hexose transporter \\
\hline YER142C & MAG1 & 6.8 & $5.46 \times 10^{-7}$ & 3-methyl-adenine DNA glycosylase \\
\hline YBR046C & ZTA1 & 6.7 & $1.13 \times 10^{-5}$ & NADPH-dependent quinone reductase \\
\hline YNL231C & PDR16 & 6.6 & $7.41 \times 10^{-3}$ & Phosphatidylinositol transfer protein (PITP) \\
\hline YPL091W & GLR1 & 6.5 & $1.49 \times 10^{-5}$ & Cytosolic and mitochondrial glutathione oxidoreductase \\
\hline YGR281W & YOR1 & 6.4 & $2.16 \times 10^{-3}$ & Plasma membrane ATP-binding cassette (ABC) transporter \\
\hline YGR197C & SNG1 & 6.3 & $3.47 \times 10^{-7}$ & Protein involved in resistance to nitrosoguanidine and 6-azauracil \\
\hline YNL155W & CUZ1 & 6.1 & $5.38 \times 10^{-3}$ & Protein with a role in the ubiquitin-proteasome pathway \\
\hline YAL054C & ACS1 & 6.1 & $3.74 \times 10^{-7}$ & Acetyl-coA synthetase isoform \\
\hline YOL119C & $\mathrm{MCH} 4$ & 6.1 & $1.27 \times 10^{-5}$ & Protein with similarity to mammalian monocarboxylate permeases \\
\hline YDL168W & SFA1 & 6.0 & $1.21 \times 10^{-5}$ & $\begin{array}{l}\text { Bifunctional alcohol dehydrogenase and } \\
\text { formaldehyde dehydrogenase }\end{array}$ \\
\hline YCR021C & HSP30 & 6.0 & $5.37 \times 10^{-3}$ & Negative regulator of the $\mathrm{H}(+)$-ATPase Pma1p \\
\hline YBR256C & RIB5 & 5.9 & $1.15 \times 10^{-3}$ & Riboflavin synthase \\
\hline YOR052C & TMC1 & 5.8 & $9.56 \times 10^{-3}$ & AN1-type zinc finger protein of unknown function \\
\hline YOL155C & HPF1 & 5.8 & $6.09 \times 10^{-5}$ & Haze-protective mannoprotein \\
\hline YMR318C & ADH6 & 5.8 & $7.64 \times 10^{-3}$ & NADPH-dependent medium chain alcohol dehydrogenase \\
\hline YJL082W & IML2 & 5.8 & $4.56 \times 10^{-4}$ & Protein of unknown function \\
\hline YKL051W & SFK1 & 5.6 & $6.62 \times 10^{-6}$ & $\begin{array}{l}\text { Plasma membrane protein that may act to generate normal } \\
\text { levels of PI4P }\end{array}$ \\
\hline YER185W & PUG1 & 5.6 & $3.14 \times 10^{-5}$ & $\begin{array}{l}\text { Plasma membrane protein involved in protoprophyrin and } \\
\text { heme transport }\end{array}$ \\
\hline YIR017C & MET28 & 5.6 & $3.48 \times 10^{-6}$ & $\begin{array}{l}\text { Basic leucine zipper (bZIP) transcriptional activator in the } \\
\text { Cbf1p-Met4p-Met28p complex }\end{array}$ \\
\hline YHL024W & RIM4 & 5.5 & $4.66 \times 10^{-6}$ & Putative RNA-binding protein \\
\hline YGR243W & MPC3 & 5.4 & $7.07 \times 10^{-5}$ & Highly conserved subunit of mitochondrial pyruvate carrier \\
\hline YGL010W & MPO1 & 5.3 & $7.58 \times 10^{-6}$ & Protein involved in metabolism of phytosphingosine \\
\hline YDR513W & GRX2 & 5.1 & $6.09 \times 10^{-3}$ & Cytoplasmic glutaredoxin \\
\hline YHR179W & OYE2 & 5.1 & $1.04 \times 10^{-2}$ & $\begin{array}{l}\text { Conserved NADPH oxidoreductase containing flavin } \\
\text { mononucleotide (FMN) }\end{array}$ \\
\hline YDR059C & UBC5 & 5.1 & $2.39 \times 10^{-4}$ & Ubiquitin-conjugating enzyme \\
\hline YMR276W & DSK2 & 5.0 & $5.01 \times 10^{-3}$ & Nuclear-enriched ubiquitin-like polyubiquitin-binding protein \\
\hline
\end{tabular}

${ }^{*}$ Fold change (FC) refers to the fold induction of the genes as compared to the untreated control.

Table 2. Genes > 5-fold upregulated upon OTA (ochratoxin A) exposure.

\begin{tabular}{ccccl}
\hline Gene & Standard Name & FC * & $p$-Value & \multicolumn{1}{c}{ Description } \\
\hline YER106W & MAM1 & 60.2 & $2.77 \times 10^{-8}$ & Monopolin \\
YGR225W & AMA1 & 57.4 & $9.19 \times 10^{-10}$ & Activator of meiotic anaphase promoting complex (APC/C) \\
YER179W & DMC1 & 40.5 & $5.34 \times 10^{-7}$ & Meiosis-specific recombinase \\
YOR298W & MUM3 & 33.5 & $9.62 \times 10^{-4}$ & Protein of unknown function \\
YFL011W & HXT10 & 33.2 & $1.38 \times 10^{-7}$ & Putative hexose transporter \\
YLL046C & RNP1 & 27.3 & $1.08 \times 10^{-7}$ & Ribonucleoprotein \\
YER104W & RTT105 & 26.0 & $3.22 \times 10^{-8}$ & Protein with a role in regulation of Ty1 transposition \\
YLR377C & FBP1 & 23.3 & $1.62 \times 10^{-7}$ & Fructose-1,6-bisphosphatase \\
YDR523C & SPS1 & 22.7 & $6.27 \times 10^{-6}$ & Putative protein serine/threonine kinase \\
YHR176W & FMO1 & 20.2 & $1.11 \times 10^{-5}$ & Flavin-containing monooxygenase \\
YBR040W & FIG1 & 19.7 & $1.16 \times 10^{-7}$ & Integral membrane protein \\
YGR059W & SPR3 & 18.6 & $4.74 \times 10^{-5}$ & septin protein involved in sporulation \\
YEL039C & CYC7 & 16.9 & $6.54 \times 10^{-7}$ & Cytochrome c isoform 2 \\
YMR101C & SRT1 & 16.7 & $3.73 \times 10^{-7}$ & Forms the dehydrodolichyl diphosphate syntase (DDS) complex \\
YDR218C & SPR28 & 14.1 & $1.11 \times 10^{-6}$ & Mith NUS1 \\
YDR256C & CTA1 & 13.5 & $7.51 \times 10^{-8}$ & Catalic septin A \\
YIL113W & SDP1 & 13.3 & $2.62 \times 10^{-7}$ & Stress-inducible dual-specificity MAP kinase phosphatase \\
YOL123W & HRP1 & 12.9 & $1.98 \times 10^{-6}$ & Subunit of cleavage factor I complex \\
YGL254W & FZF1 & 12.6 & $2.03 \times 10^{-7}$ & Transcription factor involved in sulfite metabolism \\
YPL201C & YIG1 & 12.4 & $3.23 \times 10^{-5}$ & Protein that interacts with glycerol 3-phosphatase \\
Q0275 & COX3 & 12.3 & $1.01 \times 10^{-4}$ & Subunit III of cytochrome c oxidase (Complex IV) \\
YFL055W & AGP3 & 12.3 & $2.34 \times 10^{-6}$ & Low-affinity amino acid permease \\
YDR259C & YAP6 & 11.4 & $1.88 \times 10^{-5}$ & Basic leucine zipper (bZIP) transcription factor \\
YPR193C & HPA2 & 11.3 & $2.74 \times 10^{-5}$ & Tetrameric histone acetyltransferase \\
\hline
\end{tabular}


Table 2. Cont

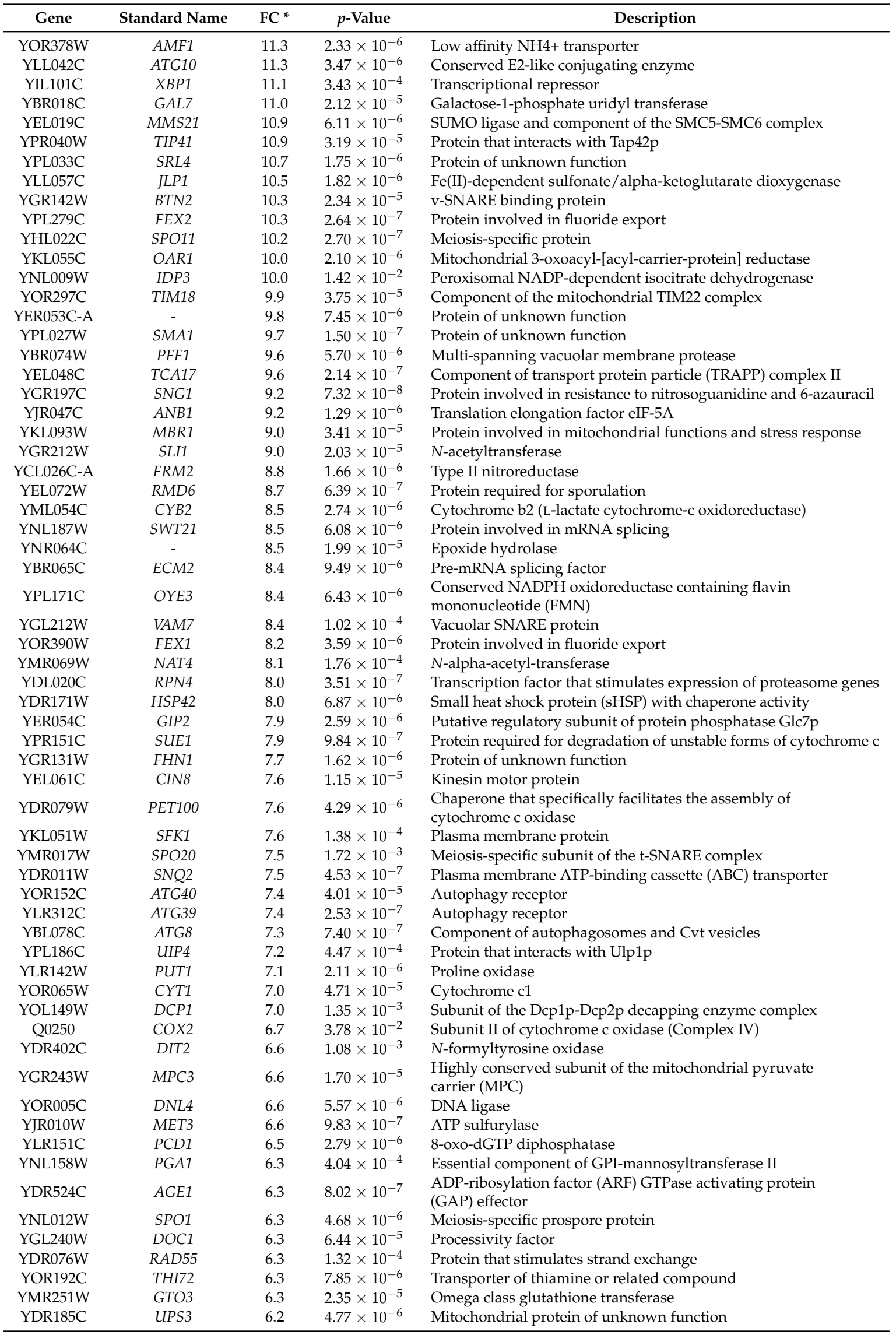


Table 2. Cont.

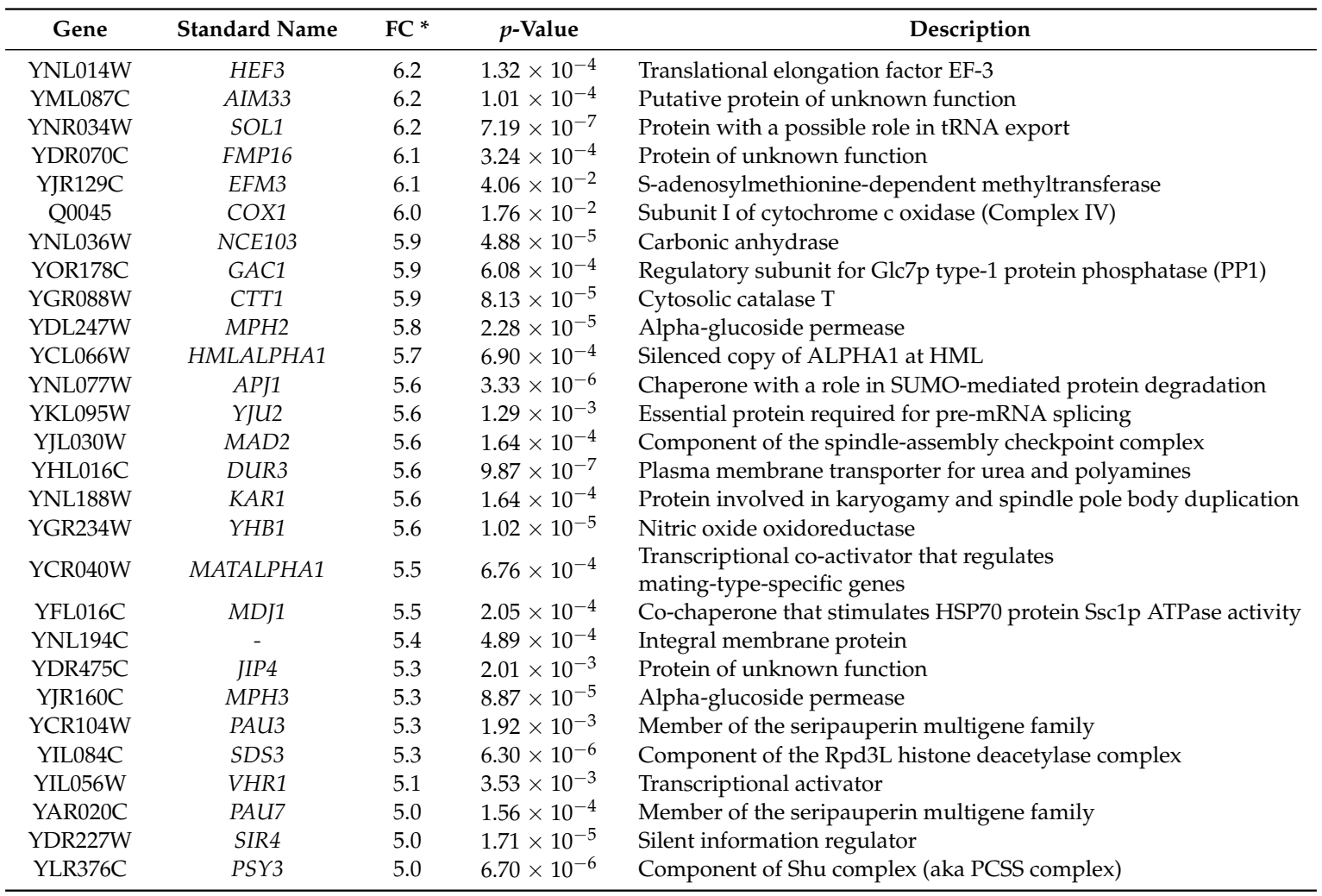

${ }^{*}$ Fold change (FC) refers to the fold induction of the genes as compared to the untreated control.

Table 3. Genes > 5-fold upregulated upon the combined CIT/OTA exposure.

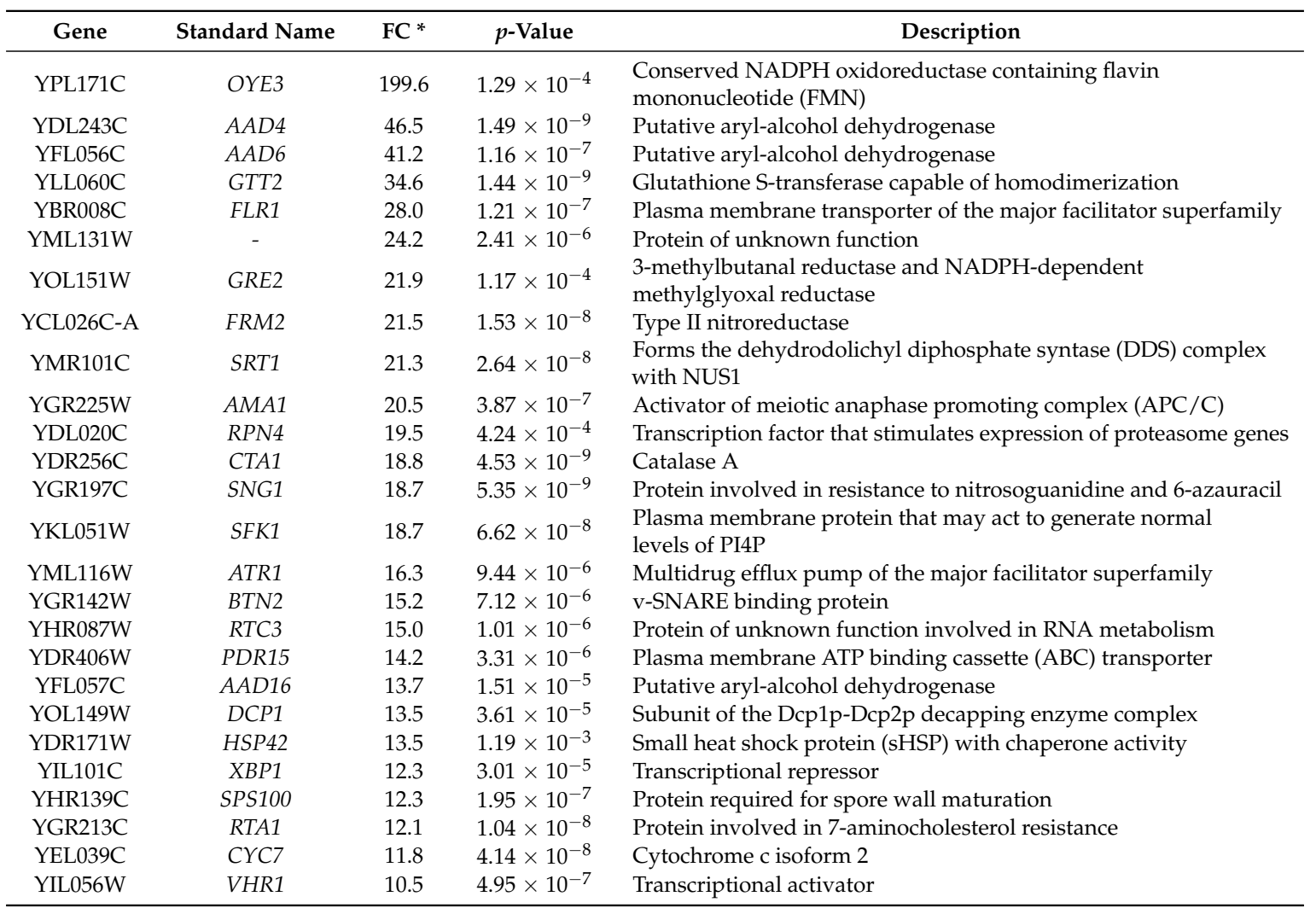


Table 3. Cont.

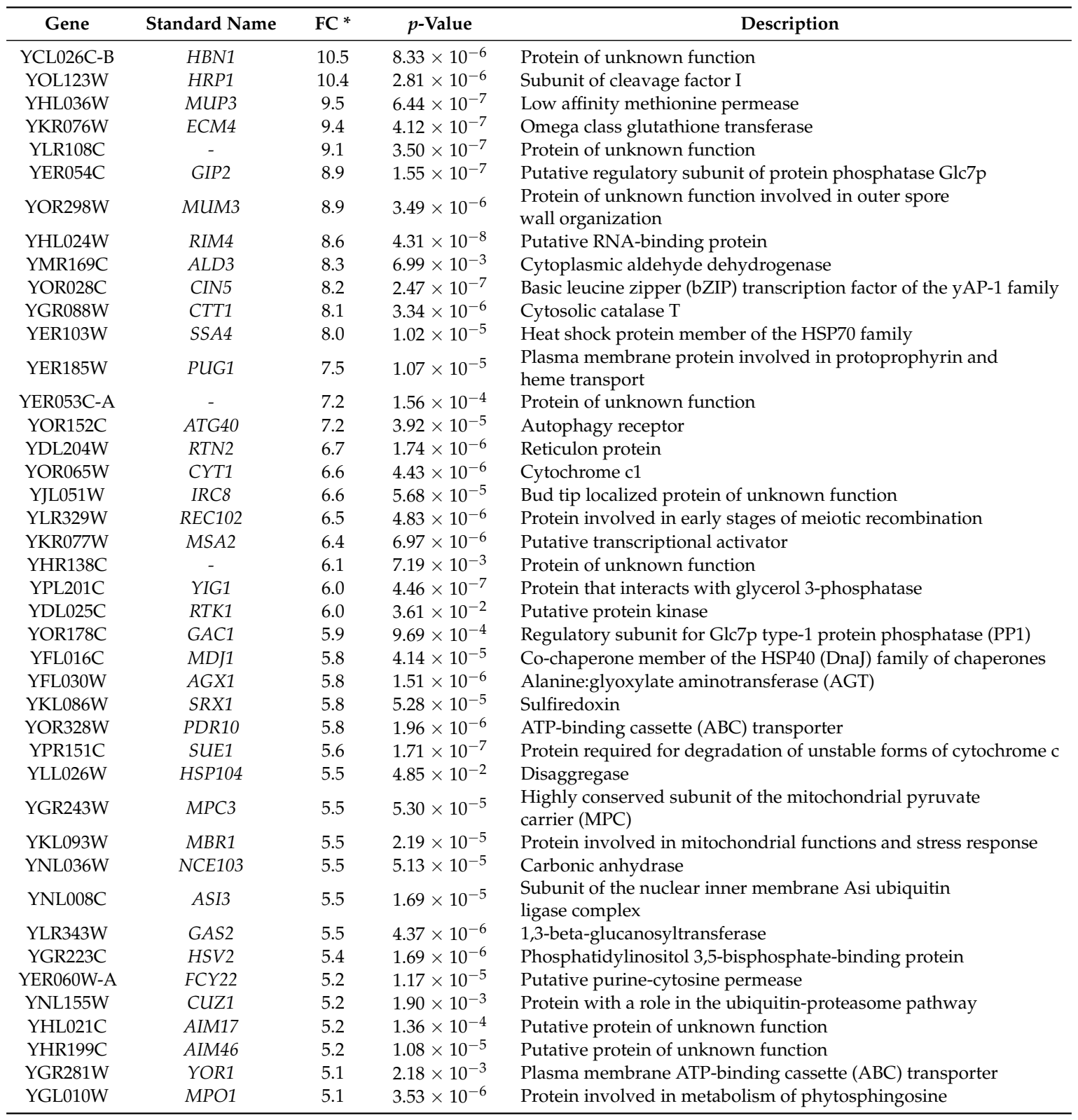

* Fold change (FC) refers to the fold induction of the genes as compared to the untreated control.

Acute CIT exposure provoked the robust upregulation of 68 yeast genes. When classified for the most statistically relevant functional groups, we identified the response to oxidative stress as the dominant group (see Table 4). These data confirmed that CIT toxicity is fundamentally based on its capacity to generate reactive oxygen species (ROS) in cells. Specifically, genes involved in the metabolism of glutathione were preferentially expressed upon CIT exposure, indicating that the antioxidant function of glutathione was necessary to palliate the toxic effect of CIT. Additionally we identified "Drug transport" as a main CIT-inducible gene group, suggesting that the activated export of the toxin might be a major determinant for the adaptation of yeast cells to CIT.

For OTA exposure, we were able to identify 115 genes whose expression was at least 5 -fold induced (Table 2). The analysis of the functional groups enriched in the dataset derived from OTA-treated cells revealed that the "response to oxidative stress" was retrieved with much less significance as compared to the CIT dataset. In turn, we identified yet other functional groups as most significantly upregulated by OTA, which belong to developmental processes of yeast cells and specifically to the differentiation 
processes of sporulation and reproduction (see Table 4). These data indicated that both mycotoxins induced different gene sets in yeast. Indeed, the comparison of the most significantly upregulated genes revealed that less than $5 \%$ (a total of only 8 genes) of the transcripts were induced commonly by either CIT or OTA as depicted in Figure 2. The subset of CIT- and OTA-responsive genes was enriched for the functional category "Oxidation-reduction process". These results clearly showed that CIT and OTA induced largely separated gene sets in the initial adaptive phase, which suggested that both mycotoxins might have different biological effects in yeast cells. We next analyzed the transcriptomic response of yeast cells to the combined exposure of CIT and OTA. A total of 68 transcripts were significantly upregulated $>5$-fold under these conditions (see Table 3 ). The functional gene groups enriched by the combined mycotoxin treatment represented a combination of the gene functions induced in the previous experiments by the separated toxin treatment. As a result, all categories covering "oxidative stress response", "drug transport", "developmental processes", and "sporulation" were significantly enriched upon the combined CIT/OTA exposure (see Table 4). Taken together, our transcriptomic survey of the response to CIT and OTA strongly supported the idea that both toxins cause distinct and separable biological responses. CIT caused a clear antioxidant response and the induction of multiple drug extrusion systems, while OTA seemed to retain a weak oxidation-related toxicity and to cause a marked deregulation of developmental genes. We wanted to further dissect these divergent toxicity effects of CIT and OTA in the yeast model.

Table 4. Functional gene groups induced by the separated or combined exposure to CIT and OTA.

\begin{tabular}{cc}
\hline CIT & p-value \\
\hline Gene Ontology Group & \\
\hline Oxidation-reduction process & $1.8 \times 10^{-13}$ \\
Cell response to oxidative stress & $2.2 \times 10^{-9}$ \\
Glutathione metabolic process & $1.8 \times 10^{-6}$ \\
Drug transport & $1.3 \times 10^{-5}$ \\
Response to reactive oxygen species & $1.3 \times 10^{-4}$ \\
\hline OTA & $p$-value \\
\hline Gene Ontology Group & $2.2 \times 10^{-8}$ \\
\hline Single organism developmental process & $2.0 \times 10^{-7}$ \\
Oxidation-reduction process & $3.0 \times 10^{-6}$ \\
Cell differentiation & $5.4 \times 10^{-6}$ \\
Sporulation & $1.6 \times 10^{-5}$ \\
Cell response to oxidative stress & $5.4 \times 10^{-3}$ \\
\hline CIT + OTA & $p$-value \\
\hline Gene Ontology Group & $1.7 \times 10^{-7}$ \\
\hline Oxidation-reduction process & $1.3 \times 10^{-5}$ \\
Drug transport & $3.1 \times 10^{-4}$ \\
Cell response to oxidative stress & $1.4 \times 10^{-3}$ \\
Spore wall assembly & $4.2 \times 10^{-3}$ \\
\hline organism developmental process &
\end{tabular}




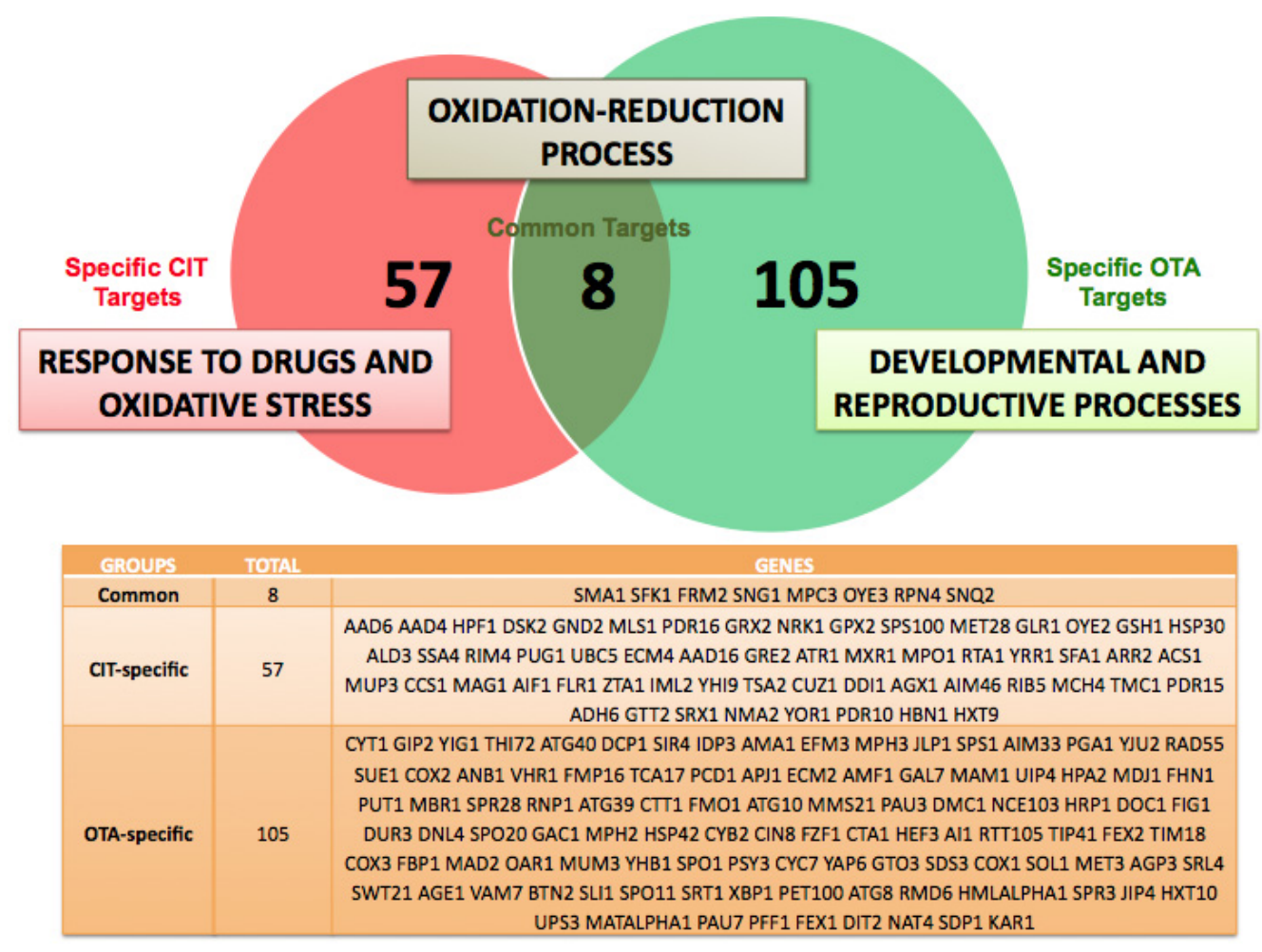

Figure 2. Ochratoxin A and citrinin activate largely nonoverlapping gene sets in the yeast genome. Venn diagram comparing the $>5$-fold induced transcripts of the yeast genome upon OTA and CIT exposure. The exclusively upregulated genes by one mycotoxin (CIT or OTA) and the commonly upregulated genes are depicted in the table. The main functional groups associated with each gene cluster are given.

\subsection{Oxidative Stress is a Hallmark for CIT, but not OTA, Toxicity}

According to our genomic expression experiments, CIT caused a specific antioxidant response in yeast cells, while antioxidant genes were only weakly induced by OTA. Additionally, CIT robustly induced the expression of a total of 7 different multidrug exporters (Flr1, Atr1, Snq2, Pdr15, Pdr10, Pdr16 and Yor1), while OTA moderately activated the expression of only the Snq2 drug exporter. We therefore wanted to quantify the importance of the antioxidant response and drug transport for the resistance to CIT or OTA. We employed specific yeast mutants with a defect in the oxidative stress adaptation (yap1, skn7) or multidrug export $(s n q 2$, yor1) and tested their resistance to CIT or OTA in comparison to wild type cells. As shown in Figure 3, the lack of the principal transcriptional activator of the oxidative stress defense Yap1 or of the multidrug transporter Snq2 rendered yeast cells hypersensitive to CIT, but not OTA. This sensitivity was observed after $8 \mathrm{~h}$ of toxin treatment. The deletion of a second transcription factor involved in the antioxidant response, Skn7, or an alternative multidrug exporter, Yor1, resulted in a weaker sensitivity phenotype exclusively in the case of CIT, which was observed after a prolonged toxin treatment $(24 \mathrm{~h})$. These data indicated that the antioxidant defense and the activated toxin export are key features for CIT detoxification, which are dispensable for the cellular defense against OTA.

We next wanted to test whether CIT and OTA caused different biological effects in the first instances of exposure. We therefore applied different live cell gene expression reporters in yeast cells to monitor transcriptional responses, which are triggered by distinct biological stimuli. Since we have previously shown that the Pdr5 drug transporter is important for the response to both CIT and OTA, we used a PDR5-luciferase expressing strain to monitor the induction of PDR5, which is activated by the accumulation of both toxins in the cell interior and not linked to a specific type of stress. 
Furthermore, we recorded the activation of two additional reporters, the general stress-inducible GRE2-luciferase, and the oxidative stress-inducible AP1-luciferase fusion [42]. We obtained the complete dose-response profiles of all three reporter strains upon increasing CIT and OTA exposures (Figure 4A). The relationship between the toxin dose and the transcriptional output $\left(\mathrm{A}_{\max }\right)$ allowed us to visualize the relative sensibilities, with which each reporter was activated by the two mycotoxins (Figure 4B), and to observe important differences. Both CIT and OTA induced the PDR5-lucCP reporter with similar dose-response kinetics. However, the stress-specific GRE2 and AP1 reporters were activated by CIT in a much more sensitive manner as compared to OTA (Figure 4B). Remarkably, the oxidative stress specific AP1-luciferase reporter remained completely uninduced even at the highest OTA concentrations. These data, together with the previous phenotypic analysis of specific yeast mutants, clearly indicated that CIT and OTA have divergent biological effects in cells. Taking together all the results presented here, CIT exposure causes strong oxidative stress, which triggers a massive transcriptional antioxidant and drug extrusion response, while OTA mainly deregulates developmental genes and only marginally induces the antioxidant defense.

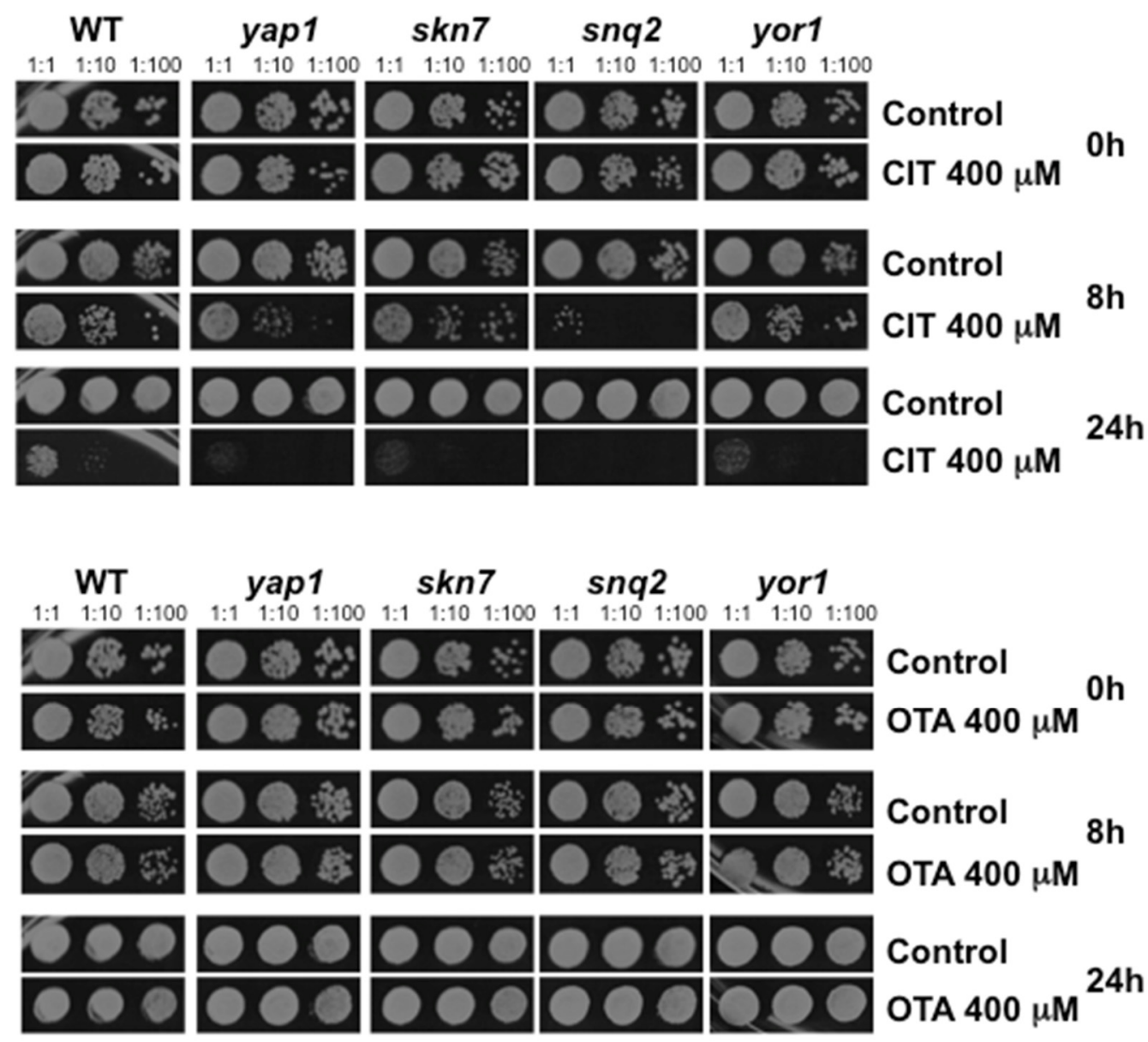

Figure 3. Citrinin, but not ochratoxin A, toxicity is exacerbated in mutants with a defective antioxidant response or multidrug export. The indicated yeast strains were treated or not with $400 \mu \mathrm{M}$ CIT (upper panel) or $400 \mu \mathrm{M}$ OTA (lower panel) for the indicated time. Serial dilutions 1:1, 1:10, and 1:100 of the yeast cultures were then assayed for survival on yeast extract peptone dextrose (YPD) agar plates without mycotoxins. 
A
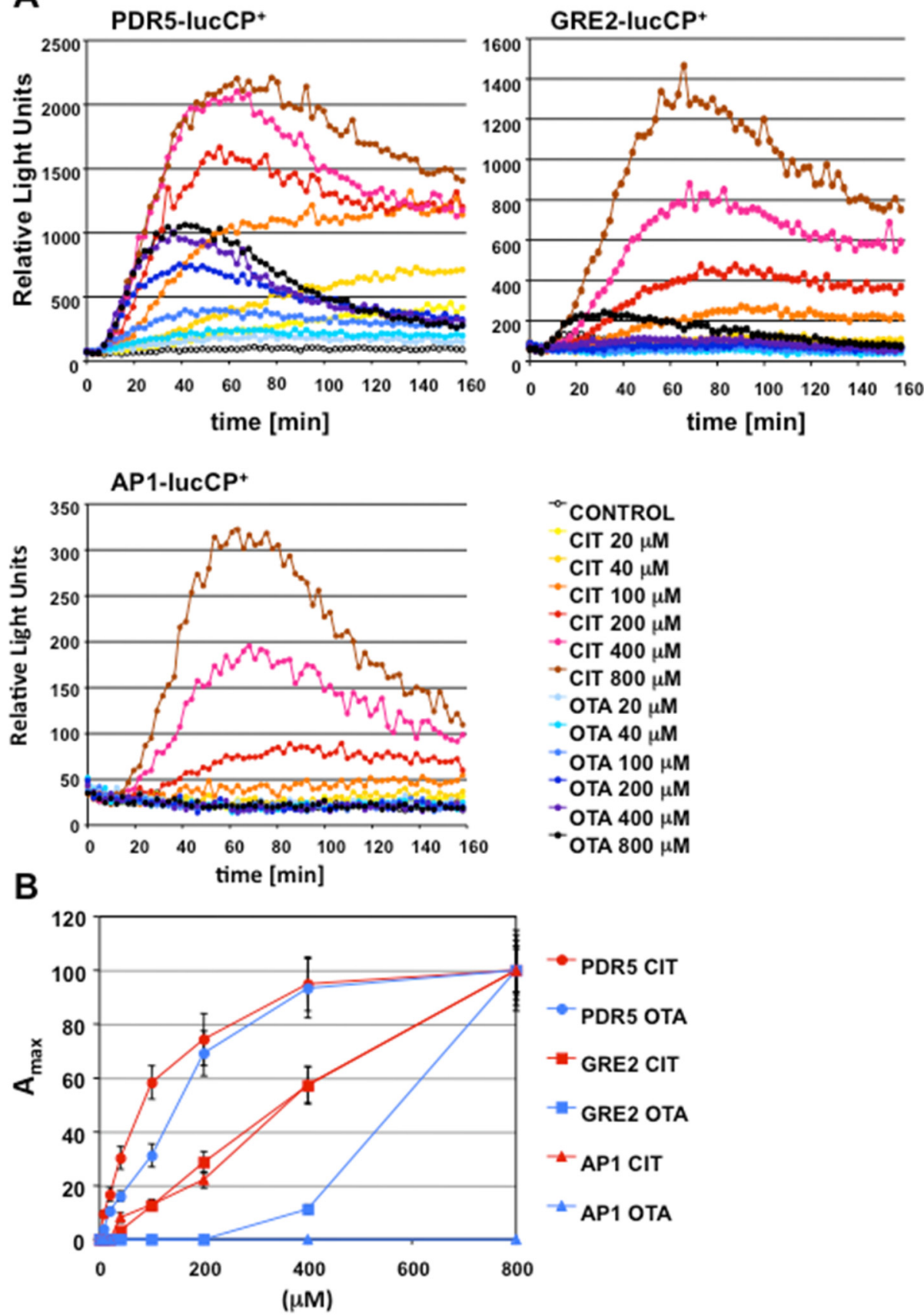

\section{- PDR5 CIT}

$\rightarrow$ PDR5 OTA

- GRE2 CIT

- GRE2 OTA

- AP1 CIT

- AP1 OTA

Figure 4. CIT, as opposed to OTA, induces a sensitive oxidative and general stress response in yeast cells. (A) OTA and CIT induction of the PDR5-, GRE2- and AP1-luciferase reporters. Live cell reporter fusions with destabilized luciferase were used in yeast wild type cells and the induction of both genes was measured in real time upon the indicated mycotoxin doses. The data are derived from three independent culture aliquots and had an error of $<15 \%$. (B) Dose-response profiles of the different luciferase reporters. The maximal steady-state activity $\left(\mathrm{A}_{\max }\right)$ was calculated for each reporter strain and toxin dose and plotted against the mycotoxin concentration. $A_{\max }$ for the highest toxin exposure was arbitrarily set to 100 .

\section{Discussion}

Here we compare the toxicity targets of the mycotoxins ochratoxin A and citrinin using yeast as a model. Saccharomyces cerevisiae is a very suitable organism to investigate the adaptive response 
triggered by OTA and CIT, because both toxins cause rapid and profound changes in gene expression in yeast. Moreover, yeast transcriptional responses can be compared quantitatively in real time for different stress-specific reporters and additionally on a genomic scale. These approaches are thus suitable as a diagnostic tool to discern divergent and common biological effects of toxins. It is important to note that yeast cells seem to resist much higher CIT and OTA doses as compared to mammalian cells. The reasons for this might be a very efficient extrusion by multidrug transporters in this organism-which is shown here as being especially relevant for CIT detoxification-or the function of the yeast cell wall, which might serve as a primary barrier for mycotoxins. The adsorption by the yeast cell wall is actually an emerging biotechnological approach to control the concentration of different mycotoxins including OTA $[43,44]$.

A common defense strategy of eukaryotic cells against many unrelated toxic compounds and xenobiotics is the activation of multidrug transporters at the plasma membrane [45,46]. In yeast cells, such as in other fungi and human cells, the intracellular levels of toxic molecules are directly sensed by specialized transcription factors, which in turn activate the expression of multidrug transporter genes in an attempt to physically extrude the toxic agents from the cell interior [47]. Here we take advantage of a specific drug efflux pump, Pdr5, which seems to be important for both CIT and OTA detoxification. Mutants for Pdr5 respond in a much more sensitive manner to both mycotoxins, as indicated by a more pronounced transcriptional activation of stress reporters by lower toxin concentrations. Although not tested directly, we assume that $p d r 5$ mutant cells accumulate higher CIT and OTA concentrations. We took advantage of this sensitivity phenotype to carry out genomic profiling experiments. The use of a hypersensitive mutant strain and the selection of optimized toxin concentrations and time points for sample preparation favored the identification of many significantly deregulated gene functions in the immediate response to both compounds. We show that the expression of the PDR5 gene is activated by CIT and OTA with similar dose response profiles (Figure 3B). This result indicates that both mycotoxins are similarly taken up by yeast cells and that the differences in the gene expression profiles are not due to a differential intracellular accumulation of the two compounds.

Citrinin induces the expression of many different multidrug transporters, and the functional category "Drug membrane transport" is significantly enriched among the CIT target genes. Seven multidrug exporter genes are highly induced by CIT: FLR1, ATR1, SNQ2, PDR15, PDR10, PDR16, and YOR1. All of these transporters are localized, at least in part, at the plasma membrane. Thus the inducible active transport of CIT from the cytosol to the cell exterior is an important feature of detoxification of this mycotoxin in yeast cells. Accordingly, we detect an increased sensitivity to CIT by the loss of individual transporters such as Pdr5, Snq2 or Yor1. OTA, however, has a much weaker impact on the induction of the multidrug extrusion system, which coincides with the CIT response only in the moderate induction of the SNQ2 gene. Of note, the yeast pleiotropic drug response is activated by the mere presence of the compound in the cell interior and also by the cytotoxic stress triggered by the compound. Thus the higher impact of CIT on the ROS balance of the cell as compared to OTA could result in a much more profound transcriptional activation of the multidrug export system.

Here we show that the predominant mechanism of CIT toxicity is the induction of oxidative stress. Moreover, oxidative stress reporters are immediately upregulated upon CIT exposure and yeast mutants with a weakened antioxidant defense are hypersensitive to this mycotoxin, which altogether suggests that the induction of ROS inside cells is a primary mode of CIT action. Our result is in agreement with a previous transcriptomic assay in yeast upon prolonged CIT treatment [41] and with several studies showing CIT induced oxidative damage in diverse cellular models from yeast to humans [26-28,30]. As a consequence, external addition of antioxidants usually alleviates CIT toxicity $[25,48,49]$. How, at the molecular level, CIT increases intracellular ROS levels is currently unknown, however, several studies have implied an inhibition of mitochondrial respiration in CIT-activated oxidative stress $[29,31,50]$. On the other hand, we demonstrate here that OTA has a much less pronounced impact on the yeast antioxidant response at the genomic level, which is further corroborated by specific oxidative stress reporters. Thus, oxidative stress might not be the primary 
toxicity mechanism for this mycotoxin. This divergent impact of CIT and OTA on ROS production is in complete agreement with a recent study showing that CIT-, but not OTA-induced hepatotoxicity, is efficiently counteracted by antioxidant treatment [49]. However, the genomic response of yeast to OTA does include the upregulation of some antioxidant functions, which interestingly are different from the antioxidant genes induced by CIT. OTA induces, for example, the expression of both mitochondrial/peroxisomal and cytosolic catalases (Ctt1 and Cta1), while CIT preferentially stimulates enzymatic functions involved in glutathione metabolism (Ecm4, Glr1, Gsh1, Gtt2, and Grx2). Thus, apart from considerable differences in absolute ROS induction, it might be possible that CIT and OTA produce distinct types of reactive oxygen species. These differences are striking because CIT and OTA are structurally related mycotoxins. Both share a dihydroisocoumarin moiety as the central structure element, which is coupled to the amino acid phenylalanine in the case of OTA. However, a functional divergence has been suggested also with respect to the environmental conditions, which induce the biosynthesis of CIT or OTA in their natural producer Penicillium verrucosum. Here different stress conditions, such as oxidative or salt stress, have been shown to differentially favor the production of one mycotoxin over the other $[19,20]$.

Despite a large scientific effort, the critical mechanism underlying OTA cytotoxicity still remains unknown. Oxidative stress has been widely implied in OTA action [15], but it certainly cannot explain the carcinogenic properties of this mycotoxin. Here we confirm that OTA is able to trigger an antioxidant response in yeast, however, ROS production is not the principle effect of OTA. This is in agreement with recent studies, which demonstrate in rats that renal carcinogenicity and cell cycle aberrations caused by OTA cannot be explained by oxidative damage [51,52]. Here we show that OTA treatment causes a general deregulation of developmental genes in yeast. This effect is OTA-specific and is not observed upon CIT exposure. The affected gene functions are related to the processes of meiosis and sporulation, which are normally tightly repressed in haploid yeast cells such as the strains used here for the transcriptomic experiments. Therefore, OTA seems to cause a genomic reprogramming of a developmental process, which is normally exclusively triggered in diploid yeast cells upon the appropriate environmental stimuli [53,54]. A tight epigenetic control, composed of specific DNA-binding factors which recruit histone deacetylases such as the Hst1 sirtuin to meiotic and sporulation genes, are known in yeast to assure repression of these developmental genes in haploid cells [55-57]. How OTA can interfere with the epigenetic control of silenced genes in yeast is currently only speculative, but opens an emerging research towards the biological function of this mycotoxin. This is of outstanding importance because the interference with gene silencing and the function of sirtuin histone deacetylases are hallmarks in the reprogramming of cancer cells $[58,59]$ and thus could provide insights into the carcinogenic function of OTA. Taken together, our results demonstrate divergent biological effects of two related mycotoxins, which will be important for understanding their toxicity mechanisms at the molecular level.

\section{Materials and Methods}

\subsection{Yeast Strains and Growth Conditions}

Saccharomyces cerevisiae strains used in this study were: wild type BY4741 (MATa; his3 $\Delta 1$; leu2 $\Delta 0$; met15 $\Delta 0$; ura3 $\Delta 0$ ) and the mutant alleles yap1::KanMX4; skn7::KanMX4; yor1::KanMX4; pdr5::KanMX4; snq2::KanMX4. For luciferase assays the cells were transformed with the respective lucCP${ }^{+}$fusion plasmids and grown in synthetic dextrose (SD) medium which contained $0.67 \%$ yeast nitrogen base, $50 \mathrm{mM}$ succinic acid pH 5.5, 2\% dextrose, $100 \mathrm{mg} / \mathrm{L}$ methionine, $100 \mathrm{mg} / \mathrm{L}$ leucine, and $25 \mathrm{mg} / \mathrm{L}$ uracil. For CIT and OTA sensitivity assays on agar plates, the respective yeast strains were grown in SD liquid medium containing $2 \%$ dextrose to exponential growth phase and then incubated with $400 \mu \mathrm{M}$ of CIT or OTA for the indicated time in small culture aliquots in multiwell plates at $28^{\circ} \mathrm{C}$. Citrinin and ochratoxin A were purchased from Enzo Life Sciences (Farmingdale, NY, USA), and stock solutions were prepared with DMSO as the solvent. 


\subsection{Plasmid Constructions}

The destabilized luciferase reporter fusions with the natural GRE2 or SOD2 promoters are described elsewhere $[60,61]$. Briefly, the GRE2-lucCP ${ }^{+}$fusion contains the upstream 940 nucleotides of the GRE2 gene fused with the destabilized luciferase luc $\mathrm{CP}^{+}$gene in a centromeric HIS3-containing yeast expression plasmid. The SOD2-lucCP ${ }^{+}$fusion contains the upstream 977 nucleotides of the SOD2 gene in the same vector backbone. The AP-1-specific destabilized luciferase reporter is described in [60]. Briefly, it contains a triple insertion of the AP-1 promoter element in the $\mathrm{CYC1}$ core promoter fused to lucCP ${ }^{+}$in centromeric HIS3-containing yeast expression plasmids. A PDR5-luciferase expressing reporter strain was created by integrative transformation of a PDR5-lucCP ${ }^{+}-\mathrm{Kan} \mathrm{MX}$ DNA cassette into yeast wild type strain BY4741 to replace the endogenous PDR5 gene with the destabilized luciferase gene.

\subsection{Live Cell Luciferase Assays}

Yeast strains transformed with the respective luciferase reporter plasmids were grown at $28^{\circ} \mathrm{C}$ overnight in $\mathrm{SD}$ medium to $\mathrm{OD}=2$ at $600 \mathrm{~nm}$. The culture volume necessary for the entire luciferase assay was incubated on a roller at $28{ }^{\circ} \mathrm{C}$ for $90 \mathrm{~min}$ with $0.5 \mathrm{mM}$ luciferin (Synchem, Felsberg, Germany) from a $10 \mathrm{mM}$ stock solution in Dimethylsulfoxide. The culture was then distributed in $120 \mu \mathrm{L}$ aliquots in white 96-well plates (Nunc, Penfield, NY, USA) and growing concentrations of CIT or OTA were added from a stock solution in DMSO. In Figure 1, $200 \mu \mathrm{M}(=50 \mathrm{ppm}), 800 \mu \mathrm{M}$ (= $200 \mathrm{ppm})$, and $1600 \mu \mathrm{M}(=400 \mathrm{ppm})$ of CIT and $124 \mu \mathrm{M}(=50 \mathrm{ppm}), 497 \mu \mathrm{M}(=200 \mathrm{ppm})$, and $994 \mu \mathrm{M}$ (= $400 \mathrm{ppm})$ of OTA were applied. Additionally, a constant dose of $200 \mu \mathrm{M}(=50 \mathrm{ppm})$ of CIT was combined with growing OTA concentrations (124 $\mu \mathrm{M}(=50 \mathrm{ppm}), 497 \mu \mathrm{M}(=200 \mathrm{ppm})$, and $994 \mu \mathrm{M}$ $(=400 \mathrm{ppm})$ ). In Figure 3, $20 \mu \mathrm{M}, 40 \mu \mathrm{M}, 100 \mu \mathrm{M}, 200 \mu \mathrm{M}, 400 \mu \mathrm{M}$, and $800 \mu \mathrm{M}$ of CIT or OTA were used. The mock-treated samples contained the same concentration of solvent without the mycotoxin. The light emission from the culture aliquots was continuously recorded in a GloMax Multidetection System (Promega, Madison, WI, USA) in the luminometer mode. Data were normalized for the absolute number of cells used in the assay and processed in Microsoft Excel (2010). For each condition, three independent culture aliquots were analyzed. The maximal luciferase activity depicted in Figures $1 \mathrm{C}$ and $4 \mathrm{~B}$ was calculated by correcting the maximal light emission for each treatment with the value obtained for the mock-treated culture.

\subsection{Yeast Sensitivity Assays}

For plate assays, the yeast strains under study were grown in SD liquid medium to exponential growth phase. 1:1, 1:10 and 1:100 dilutions of culture aliquots were then distributed in multiwell plates and exposed for the indicated time to CIT or OTA added from stock solutions in DMSO. Equal amounts of cells were then plated on fresh yeast extract peptone dextrose (YPD) agar plates, which were incubated at $28^{\circ} \mathrm{C}$ for 2 days.

\subsection{Microarray Experiments and Analysis}

For the comparison of the transcriptome upon various mycotoxin treatments, the pdr5 mutant strain was used. Cells were grown in SD medium until exponential phase and then subjected to four different toxin treatments: control (mock treated with solvent), CIT (200 ppm for $60 \mathrm{~min}$ ), OTA (200 ppm for $30 \mathrm{~min}$ ), and a combination of both mycotoxins CIT/OTA (100 ppm each for $30 \mathrm{~min}$ ). Total RNA was prepared from four independent culture aliquots for each condition using the acid phenol extraction method. Total RNA was further purified with the RNeasy Mini kit (Qiagen, Valencia, CA, USA). The samples were labeled using the one-color method with Cy3 fluorophore, hybridized to Agilent Yeast Gene Expression $8 \times 15 \mathrm{~K}$ microarrays, and scanned with Agilent DNA Microarray Scanner (G2505B, Agilent Technologies, Santa Clara, CA, USA). Raw data were obtained using the Feature Extraction software 9.5.1 (Agilent Technologies, Santa Clara, CA, USA, 2007). These procedures 
were performed by the Genomic Service of the Instituto de Biología Molecular y Celular de Plantas (IBMCP, Valencia, Spain). Data analysis was performed using GeneSpring 12.6 (Agilent Technologies, Santa Clara, CA, USA). Data were normalized using the quantile method and then statistically analyzed with the Student $t$-Test. Significant differences in gene expression were selected using a $p$-value $<0.05$. To avoid the detection of false positives, a multiple testing correction (Bonferroni FWER) was applied to obtain corrected $p$-values. The complete dataset from all transcriptomic experiments of this publication has been assigned accession number GSE84187 in the Gene Expression Omnibus (GEO) Database. Significantly enriched functional gene groups were identified with the YeastMine Gene Ontology (GO) search option of the Saccharomyces cerevisiae Genome Database (SGD).

Acknowledgments: We thank Lorena Latorre and Javier Forment for their help with the microarray experiments and data analysis. This work was funded only in the initial phase by a grant from Ministerio de Economía y Competitividad (BFU2011-23326). We thank the Fond for Open Access Publication from Consejo Superior de Investigaciones Científicas (CSIC) for supporting publication costs of this article.

Author Contributions: M.P. and A.P.-A. conceived and designed the experiments; E.V.-P. performed the experiments; E.V.-P., M.P. and A.P.-A. analyzed the data; M.P. and A.P.-A. wrote the paper.

Conflicts of Interest: The authors declare no conflict of interest. The founding sponsors had no role in the design of the study; in the collection, analyses, or interpretation of data; in the writing of the manuscript, and in the decision to publish the results.

\section{References}

1. Bennett, J.W.; Klich, M. Mycotoxins. Clin. Microbiol. Rev. 2003, 16, 497-516. [CrossRef] [PubMed]

2. Marroquin-Cardona, A.G.; Johnson, N.M.; Phillips, T.D.; Hayes, A.W. Mycotoxins in a changing global environment-A review. Food Chem. Toxicol. 2014, 69, 220-230. [CrossRef] [PubMed]

3. Moretti, A.; Susca, A.; Mule, G.; Logrieco, A.F.; Proctor, R.H. Molecular biodiversity of mycotoxigenic fungi that threaten food safety. Int. J. Food Microbiol. 2013, 167, 57-66. [CrossRef] [PubMed]

4. Wu, F.; Groopman, J.D.; Pestka, J.J. Public health impacts of foodborne mycotoxins. Annu. Rev. Food Sci. Technol. 2014, 5, 351-372. [CrossRef] [PubMed]

5. Mobius, N.; Hertweck, C. Fungal phytotoxins as mediators of virulence. Curr. Opin. Plant. Biol. 2009, 12, 390-398. [CrossRef] [PubMed]

6. Doi, K.; Uetsuka, K. Mechanisms of Mycotoxin-induced Dermal Toxicity and Tumorigenesis through Oxidative Stress-related Pathways. J. Toxicol. Pathol. 2014, 27, 1-10. [CrossRef] [PubMed]

7. Escriva, L.; Font, G.; Manyes, L. In vivo toxicity studies of fusarium mycotoxins in the last decade: A review. Food. Chem. Toxicol. 2015, 78, 185-206. [CrossRef] [PubMed]

8. Vettorazzi, A.; Gonzalez-Penas, E.; de Cerain, A.L. Ochratoxin A kinetics: A review of analytical methods and studies in rat model. Food Chem. Toxicol. 2014, 72, 273-288. [CrossRef] [PubMed]

9. Wang, Y.; Wang, L.; Liu, F.; Wang, Q.; Selvaraj, J.N.; Xing, F.; Zhao, Y.; Liu, Y. Ochratoxin A Producing Fungi, Biosynthetic Pathway and Regulatory Mechanisms. Toxins 2016, 8. [CrossRef] [PubMed]

10. Koszegi, T.; Poor, M. Ochratoxin A: Molecular Interactions, Mechanisms of Toxicity and Prevention at the Molecular Level. Toxins 2016, 8. [CrossRef] [PubMed]

11. Faucet, V.; Pfohl-Leszkowicz, A.; Dai, J.; Castegnaro, M.; Manderville, R.A. Evidence for covalent DNA adduction by Ochratoxin A following chronic exposure to rat and subacute exposure to pig. Chem. Res. Toxicol. 2004, 17, 1289-1296. [CrossRef] [PubMed]

12. Mantle, P.G.; Faucet-Marquis, V.; Manderville, R.A.; Squillaci, B.; Pfohl-Leszkowicz, A. Structures of covalent adducts between DNA and Ochratoxin A: A new factor in debate about genotoxicity and human risk assessment. Chem. Res. Toxicol. 2010, 23, 89-98. [CrossRef] [PubMed]

13. Pfohl-Leszkowicz, A.; Manderville, R.A. An update on direct genotoxicity as a molecular mechanism of ochratoxin a carcinogenicity. Chem. Res. Toxicol. 2012, 25, 252-262. [CrossRef] [PubMed]

14. Rahimtula, A.D.; Bereziat, J.C.; Bussacchini-Griot, V.; Bartsch, H. Lipid peroxidation as a possible cause of ochratoxin A toxicity. Biochem. Pharmacol. 1988, 37, 4469-4477. [CrossRef]

15. Sorrenti, V.; di Giacomo, C.; Acquaviva, R.; Barbagallo, I.; Bognanno, M.; Galvano, F. Toxicity of ochratoxin a and its modulation by antioxidants: A review. Toxins 2013, 5, 1742-1766. [CrossRef] [PubMed] 
16. Bragulat, M.R.; Martinez, E.; Castella, G.; Cabanes, F.J. Ochratoxin A and citrinin producing species of the genus Penicillium from feedstuffs. Int. J. Food. Microbiol. 2008, 126, 43-48. [CrossRef] [PubMed]

17. Vrabcheva, T.; Usleber, E.; Dietrich, R.; Martlbauer, E. Co-occurrence of ochratoxin A and citrinin in cereals from Bulgarian villages with a history of Balkan endemic nephropathy. J. Agric. Food. Chem. 2000, 48, 2483-2488. [CrossRef] [PubMed]

18. Ostry, V.; Malir, F.; Ruprich, J. Producers and important dietary sources of ochratoxin A and citrinin. Toxins 2013, 5, 1574-1586. [CrossRef] [PubMed]

19. Schmidt-Heydt, M.; Graf, E.; Stoll, D.; Geisen, R. The biosynthesis of ochratoxin A by Penicillium as one mechanism for adaptation to $\mathrm{NaCl}$ rich foods. Food Microbiol. 2012, 29, 233-241. [CrossRef] [PubMed]

20. Schmidt-Heydt, M.; Stoll, D.; Schutz, P.; Geisen, R. Oxidative stress induces the biosynthesis of citrinin by Penicillium verrucosum at the expense of ochratoxin. Int. J. Food Microbiol. 2015, 192, 1-6. [CrossRef] [PubMed]

21. Stoll, D.; Schmidt-Heydt, M.; Geisen, R. Differences in the regulation of ochratoxin A by the HOG pathway in Penicillium and Aspergillus in response to high osmolar environments. Toxins 2013, 5, 1282-1298. [CrossRef] [PubMed]

22. Flajs, D.; Peraica, M. Toxicological properties of citrinin. Arh. Hig. Rada Toksikol. 2009, 60, 457-464. [CrossRef] [PubMed]

23. Bouslimi, A.; Ouannes, Z.; Golli, E.E.; Bouaziz, C.; Hassen, W.; Bacha, H. Cytotoxicity and oxidative damage in kidney cells exposed to the mycotoxins ochratoxin a and citrinin: Individual and combined effects. Toxicol. Mech. Methods 2008, 18, 341-349. [CrossRef] [PubMed]

24. Chan, W.H. Citrinin induces apoptosis via a mitochondria-dependent pathway and inhibition of survival signals in embryonic stem cells, and causes developmental injury in blastocysts. Biochem. J. 2007, 404, 317-326. [CrossRef] [PubMed]

25. Kumar, M.; Dwivedi, P.; Sharma, A.K.; Sankar, M.; Patil, R.D.; Singh, N.D. Apoptosis and lipid peroxidation in ochratoxin A- and citrinin-induced nephrotoxicity in rabbits. Toxicol. Ind. Health 2014, 30, 90-98. [CrossRef] [PubMed]

26. Kumar, R.; Dwivedi, P.D.; Dhawan, A.; Das, M.; Ansari, K.M. Citrinin-generated reactive oxygen species cause cell cycle arrest leading to apoptosis via the intrinsic mitochondrial pathway in mouse skin. Toxicol. Sci. 2011, 122, 557-566. [CrossRef] [PubMed]

27. Mate, G.; Gazdag, Z.; Mike, N.; Papp, G.; Pocsi, I.; Pesti, M. Regulation of oxidative stress-induced cytotoxic processes of citrinin in the fission yeast Schizosaccharomyces pombe. Toxicon 2014, 90, 155-166. [CrossRef] [PubMed]

28. Pascual-Ahuir, A.; Vanacloig-Pedros, E.; Proft, M. Toxicity mechanisms of the food contaminant citrinin: Application of a quantitative yeast model. Nutrients 2014, 6, 2077-2087. [CrossRef] [PubMed]

29. Ribeiro, S.M.; Chagas, G.M.; Campello, A.P.; Kluppel, M.L. Mechanism of citrinin-induced dysfunction of mitochondria. V. Effect on the homeostasis of the reactive oxygen species. Cell. Biochem. Funct. 1997, 15, 203-209. [CrossRef]

30. Singh, N.D.; Sharma, A.K.; Dwivedi, P.; Leishangthem, G.D.; Rahman, S.; Reddy, J.; Kumar, M. Effect of feeding graded doses of citrinin on apoptosis and oxidative stress in male Wistar rats through the F1 generation. Toxicol. Ind. Health 2016, 32, 385-397. [CrossRef] [PubMed]

31. Yu, F.Y.; Liao, Y.C.; Chang, C.H.; Liu, B.H. Citrinin induces apoptosis in HL-60 cells via activation of the mitochondrial pathway. Toxicol. Lett. 2006, 161, 143-151. [CrossRef] [PubMed]

32. Follmann, W.; Behm, C.; Degen, G.H. Toxicity of the mycotoxin citrinin and its metabolite dihydrocitrinone and of mixtures of citrinin and ochratoxin A in vitro. Arch. Toxicol. 2014, 88, 1097-1107. [CrossRef] [PubMed]

33. Klaric, M.S.; Rasic, D.; Peraica, M. Deleterious effects of mycotoxin combinations involving ochratoxin A. Toxins 2013, 5, 1965-1987. [CrossRef] [PubMed]

34. Afshari, C.A.; Hamadeh, H.K.; Bushel, P.R. The evolution of bioinformatics in toxicology: Advancing toxicogenomics. Toxicol. Sci. 2011, 120 (Suppl. 1), S225-S237. [CrossRef] [PubMed]

35. Yasokawa, D.; Iwahashi, H. Toxicogenomics using yeast DNA microarrays. J. Biosci. Bioeng. 2010, 110, 511-522. [CrossRef] [PubMed]

36. Arbillaga, L.; Azqueta, A.; van Delft, J.H.; Lopez de Cerain, A. In vitro gene expression data supporting a DNA non-reactive genotoxic mechanism for ochratoxin A. Toxicol. Appl. Pharmacol. 2007, 220, $216-224$. [CrossRef] [PubMed] 
37. Hibi, D.; Kijima, A.; Kuroda, K.; Suzuki, Y.; Ishii, Y.; Jin, M.; Nakajima, M.; Sugita-Konishi, Y.; Yanai, T.; Nohmi, T.; et al. Molecular mechanisms underlying ochratoxin A-induced genotoxicity: Global gene expression analysis suggests induction of DNA double-strand breaks and cell cycle progression. J. Toxicol. Sci. 2013, 38, 57-69. [CrossRef] [PubMed]

38. Hundhausen, C.; Boesch-Saadatmandi, C.; Matzner, N.; Lang, F.; Blank, R.; Wolffram, S.; Blaschek, W.; Rimbach, G. Ochratoxin a lowers mRNA levels of genes encoding for key proteins of liver cell metabolism. Cancer Genom. Proteom. 2008, 5, 319-332.

39. Marin-Kuan, M.; Nestler, S.; Verguet, C.; Bezencon, C.; Piguet, D.; Mansourian, R.; Holzwarth, J.; Grigorov, M.; Delatour, T.; Mantle, P.; et al. A toxicogenomics approach to identify new plausible epigenetic mechanisms of ochratoxin a carcinogenicity in rat. Toxicol. Sci. 2006, 89, 120-134. [CrossRef] [PubMed]

40. Vettorazzi, A.; van Delft, J.; Lopez de Cerain, A. A review on ochratoxin A transcriptomic studies. Food Chem. Toxicol. 2013, 59, 766-783. [CrossRef] [PubMed]

41. Iwahashi, H.; Kitagawa, E.; Suzuki, Y.; Ueda, Y.; Ishizawa, Y.H.; Nobumasa, H.; Kuboki, Y.; Hosoda, H.; Iwahashi, Y. Evaluation of toxicity of the mycotoxin citrinin using yeast ORF DNA microarray and Oligo DNA microarray. BMC Genomics 2007, 8, 95. [CrossRef] [PubMed]

42. Toone, W.M.; Morgan, B.A.; Jones, N. Redox control of AP-1-like factors in yeast and beyond. Oncogene 2001, 20, 2336-2346. [CrossRef] [PubMed]

43. Luo, Y.; Wang, J.; Liu, B.; Wang, Z.; Yuan, Y.; Yue, T. Effect of yeast cell morphology, cell wall physical structure and chemical composition on patulin adsorption. PLoS ONE 2015, 10, e0136045. [CrossRef] [PubMed]

44. Piotrowska, M.; Masek, A. Saccharomyces cerevisiae cell wall components as tools for ochratoxin A decontamination. Toxins 2015, 7, 1151-1162. [CrossRef] [PubMed]

45. Jungwirth, H.; Kuchler, K. Yeast ABC transporters-A tale of sex, stress, drugs and aging. FEBS Lett. 2006, 580, 1131-1138. [CrossRef] [PubMed]

46. Prasad, R.; Goffeau, A. Yeast ATP-binding cassette transporters conferring multidrug resistance. Annu. Rev. Microbiol. 2012, 66, 39-63. [CrossRef] [PubMed]

47. Thakur, J.K.; Arthanari, H.; Yang, F.; Pan, S.J.; Fan, X.; Breger, J.; Frueh, D.P.; Gulshan, K.; Li, D.K.; Mylonakis, E.; et al. A nuclear receptor-like pathway regulating multidrug resistance in fungi. Nature 2008, 452, 604-609. [CrossRef] [PubMed]

48. Chen, C.C.; Chan, W.H. Inhibition of citrinin-induced apoptotic biochemical signaling in human hepatoma G2 cells by resveratrol. Int. J. Mol. Sci. 2009, 10, 3338-3357. [CrossRef] [PubMed]

49. Gayathri, L.; Dhivya, R.; Dhanasekaran, D.; Periasamy, V.S.; Alshatwi, A.A.; Akbarsha, M.A. Hepatotoxic effect of ochratoxin A and citrinin, alone and in combination, and protective effect of vitamin E: In vitro study in HepG2 cell. Food Chem. Toxicol. 2015, 83, 151-163. [CrossRef] [PubMed]

50. Aleo, M.D.; Wyatt, R.D.; Schnellmann, R.G. The role of altered mitochondrial function in citrinin-induced toxicity to rat renal proximal tubule suspensions. Toxicol. Appl. Pharmacol. 1991, 109, 455-463. [CrossRef]

51. Qi, X.; Yu, T.; Zhu, L.; Gao, J.; He, X.; Huang, K.; Luo, Y.; Xu, W. Ochratoxin A induces rat renal carcinogenicity with limited induction of oxidative stress responses. Toxicol. Appl. Pharmacol. 2014, 280, 543-549. [CrossRef] [PubMed]

52. Taniai, E.; Yafune, A.; Nakajima, M.; Hayashi, S.M.; Nakane, F.; Itahashi, M.; Shibutani, M. Ochratoxin A induces karyomegaly and cell cycle aberrations in renal tubular cells without relation to induction of oxidative stress responses in rats. Toxicol. Lett. 2014, 224, 64-72. [CrossRef] [PubMed]

53. Govin, J.; Berger, S.L. Genome reprogramming during sporulation. Int. J. Dev. Biol. 2009, 53, 425-432. [CrossRef] [PubMed]

54. Winter, E. The Sum1/Ndt80 transcriptional switch and commitment to meiosis in Saccharomyces cerevisiae. Microbiol. Mol. Biol. Rev. 2012, 76, 1-15. [CrossRef] [PubMed]

55. Grunstein, M.; Gasser, S.M. Epigenetics in Saccharomyces cerevisiae. Cold Spring Harb. Perspect. Biol. 2013, 5. [CrossRef] [PubMed]

56. Pijnappel, W.W.; Schaft, D.; Roguev, A.; Shevchenko, A.; Tekotte, H.; Wilm, M.; Rigaut, G.; Seraphin, B.; Aasland, R.; Stewart, A.F. The S. cerevisiae SET3 complex includes two histone deacetylases, Hos2 and Hst1, and is a meiotic-specific repressor of the sporulation gene program. Genes Dev. 2001, 15, 2991-3004. [CrossRef] [PubMed] 
57. Xie, J.; Pierce, M.; Gailus-Durner, V.; Wagner, M.; Winter, E.; Vershon, A.K. Sum1 and Hst1 repress middle sporulation-specific gene expression during mitosis in Saccharomyces cerevisiae. EMBO J. 1999, 18, 6448-6454. [CrossRef] [PubMed]

58. Chalkiadaki, A.; Guarente, L. The multifaceted functions of sirtuins in cancer. Nat. Rev. Cancer 2015, 15, 608-624. [CrossRef] [PubMed]

59. Roth, M.; Chen, W.Y. Sorting out functions of sirtuins in cancer. Oncogene 2014, 33, 1609-1620. [CrossRef] [PubMed]

60. Dolz-Edo, L.; Rienzo, A.; Poveda-Huertes, D.; Pascual-Ahuir, A.; Proft, M. Deciphering dynamic dose responses of natural promoters and single cis elements upon osmotic and oxidative stress in yeast. Mol. Cell. Biol. 2013, 33, 2228-2240. [CrossRef] [PubMed]

61. Rienzo, A.; Pascual-Ahuir, A.; Proft, M. The use of a real-time luciferase assay to quantify gene expression dynamics in the living yeast cell. Yeast 2012, 29, 219-231. [CrossRef] [PubMed]

(C) 2016 by the authors; licensee MDPI, Basel, Switzerland. This article is an open access article distributed under the terms and conditions of the Creative Commons Attribution (CC-BY) license (http://creativecommons.org/licenses/by/4.0/). 